\title{
COOPERATIVISMO AGROPECUÁRIO NORDESTINO: DIAGNÓSTICO E TIPOLOGIA
}

\author{
Marcos SoARes dA Silva \\ Bacharel em Administração de Empresas
}

Orientador: Prot $\mathrm{Dr}$ MABCOS SAWAYA JANK

Dissertaçao apresentada - à Escola Superior de Agricultura Luiz de Queiroz, da Universidade de São Paulo, para obtenção do título de Mestre em Ciências. Área de Concentração: Economia Aplicada.

PIRACICABA

Estado de São Paulo - Brasil . .

Maio - 2000 


\title{
Dados Internacionais de Catalogaçāo na Publicação (CIP) DIVISĀO DE BIBLIOTECA E DOCUMENTAÇĀO - Campus "Luiz de Queiroz"/USP
}

\author{
Silva, Marcos Soares da \\ Cooperativismo agropecuário nordestino: diagnóstico e tipologia / Marcos Soares
} da Silva. - - Piracicaba, 2000.

245 p. : il.

Dissertação (mestrado) - - Escola Superior de Agricultura Luiz de Queiroz, 2000. Bibliografia.

1. Cooperativa agrícola 2. Cooperativismo agricola 3. Desenvolvimento rural 4. Economia agrícola 5. Finança 6. Indústria agricola 7. Produtividade agrícola I. Título

CDD 334.683

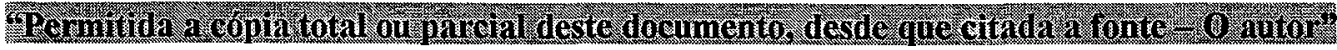


“... não raros são na história os supostos consensos que, depois de seguidos por anos, revelam-se tão claramente equivocados e injustos que causam perplexidade pensar como é que puderam prevalecer."

\section{(Demian·Fiocca)}

"De tanto ver triunfar as nulidades, de tanto ver crescer as injustiças, de tanto ver agigantarem-se os poderes nas mãos dos maus, o homem chega a desanimar-se da virtude, a rir-se da honra, a ter vergonha de ser honesto."

\section{(Rui Barbosa)}

"Gente muito perigosa, não pelo mal que faz, mas pelo bem que impede."

(François Marie Charles Fourier)

"Se algum dia vocês forem surpreendidos pela injustiça ou pela ingratidão, não deixem de crer na vida, de engrandecê-la pela decência, de construí-la pelo trabalho!"

\section{(Edson Queiroz)}

"Não entres na vereda dos perversos, nem sigas pelo caminho dos maus. Evita-o; não passes por ele; desvia-te dele e passa de largo; pois não dormem, se não fizerem mal, e foge deles o sono, se não fizerem tropeçar alguém; porque comem o pão da impiedade e bebem o vinho das violências. Mas a vereda dos justos é como a luz da aurora, que vai brilhando mais e mais até ser dia perfeito. O caminho dos perversos é como a escuridão: nem sabem eles em que tropeçam". 
A

Maria Ricardo da Silva, In memorian

Arlindo Soares da Silva

Dedico

A

Marcos Soares da Silva Júnior

Rachel Maria de Souza Soares

Raíssa Márcia de Souza Soares 


\section{AGRADECIMENTOS}

Agradeço ao Banco do Nordeste do Brasil (BNB) por ter permitido minha participação no Programa de Pós-graduação, pelo custeio de meus estudos, pelo patrocínio dos gastos da pesquisa e pelo fornecimento de dados essenciais, sem os quais não seria possível a realização desta dissertação.

Agradeço ao Departamento de Economia, Administração e Sociologia Rural, da Escola Superior de Agricultura Luiz de Queiroz, da Universidade de São Paulo, pela oportunidade de integrar o Programa de Mestrado em Economia Aplicada, em momento difícil de reorientação de minha carreira profissional.

Agradeço ao Prof. Dr. Marcos Sawaya Jank pela firme e competente orientação, pelo apoio e incentivo demonstrados durante todas as fases de realização deste trabalho de pesquisa.

Aos professores Pedro Valentim Marques e Sigismundo Bialoskorski Neto pelas relevantes sugestões apresentadas no Seminário de Dissertação e no Exame de Qualificação.

Aos professores da ESALQ-USP: Adriano Júlio de Barros Vicente de Azevedo Filho, Ana Lúcia Kassouf, Carlos José Caetano Bacha, João Gomes Martines Filho, Joaquim Bento de Souza Ferreira Filho, José Vicente Caixeta Filho, Manoel Cabral de Castro, Mirian R. P. Bacchi, Paulo Fernando Cidade de Araújo, Ricardo Shirota, Rodolfo Hoffmann e Zilda Paes de Barros Mattos pela honrosa convivência e ensinamentos.

Ao Núcleo de Economia Agrícola, do Instituto de Economia, da Universidade Estadual de Campinas (UNICAMP) por ter acolhido minha 
participação no Curso de Especialização em Formulação e Análise de Políticas Agrícolas, permitindo que eu pudesse realizar estudos complementares necessários à fundamentação desta pesquisa.

Aos professores do IE-UNICAMP: Ademar Ribeiro Romeiro, Bastiaan Phillip Reydon, José Maria F. J. da Silveira, Pedro Ramos, Rinaldo Barcia Fonseca e Walter Belik pela oportunidade de discussão de destacados temas contemporâneos relacionados à agricultura brasileira, o que muito contribuiu para o desenvolvimento deste trabalho. Ao Prof. Dr. Antônio Márcio Buainain pela honra de ter participado de sua competente equipe de pesquisa. À Profa. Dra. Ângela Antonia Kageyama que gentilmente forneceu farta literatura sobre métodos estatísticos multivariados e prestou valiosa orientação relacionada à utilização dos softwares de computação.

Agradeço aos professores da Universidade do Vale do Rio dos Sinos (UNISINOS): Dr. José Odelso Schneider e Vera Schmitz pela presteza com que disponibilizaram preciosos materiais bibliográficos. Ao Prof. Dr. Roque Lauschner, In memorian, por despertar em mim o interesse pelo cooperativismo e por ter recomendado meu nome à Escola Superior de Agricultura Luiz de Queiroz (ESALQ).

Agradeço a Amilcar Gramacho e Belmira Neves de Oliveira, da Organização das Cooperativas Brasileiras (OCB), e Regis Alimandro, do Centro de Estudos Agrícolas, da Fundação Getúlio Vargas, que graciosamente forneceram resultados, então inéditos, de pesquisa sobre o cooperativismo agropecuário brasileiro.

Agradeço aos dirigentes e funcionários das cooperativas agropecuárias do Nordeste pela disponibilidade nas entrevistas realizadas e pelo fornecimento dos dados. Ao Sr. Antônio Carlos Simões Florido, do Instituto Brasileiro de Geografia e Estatística (IBGE) pelo atendimento oportuno da demanda dos 
dados censitários. Ao Prof. Marcelo Braga, da Universidade Federal de Viçosa, pelo material bibliográfico disponibilizado. Ao Prof. Natalino Henrique Medeiros, da Universidade Estadual de Maringá, pelos comentários e sugestões apresentadas. À Ana Paula da Silva pela revisão do texto.

Agradeço a todos os técnicos e administradores do Banco do Nordeste do Brasil (BNB) que, direta ou indiretamente, envolveram-se no processo de coleta dos dados nas cooperativas amostradas.

Aos colegas de turma Ana Cláudia Piedade Sodero Martins, Daniela Cristina Manhani, Danilo Macarini Umbelino dos Santos, Ednéia da Silva Bezerra, Fábio Lanhoso de Mattos, José Arimatéia Rabelo Machado, Maristela Franco Paes Leme, Sebastião Marcos Pereira, Sylvia Loloma Hacker, Umberto Antonio Sesso Filho e Yaskara Max Raimundo pela harmoniosa convivência e cooperação.

Aos funcionários do Departamento de Economia, Administração e Sociologia Rural, da Escola Superior de Agricultura Luiz de Queiroz, Cristiane Cipriano, Elenice Cazalatina de Mattos, Ligiana Clemente do Carmo, Luciane Cristina Cipriano, Márcia Maria Beltrame, Maria Aparecida Maielli Travalini, Maria Helena Carletti, Pedro Scardua e Valdeci Altarugio pela presteza e competência com que sempre me atenderam.

Especialmente, agradeço a Helena Aparecida Cardoso pelo incentivo, apoio e dedicação voluntária em importantes fases de realização desta dissertação.

A todos os amigos e colaboradores que eu, involuntariamente, tenha omitido nesta oportunidade. 


\section{SUMÁRIO}

Página

LISTA DE FIGURAS.......................................................................... vii

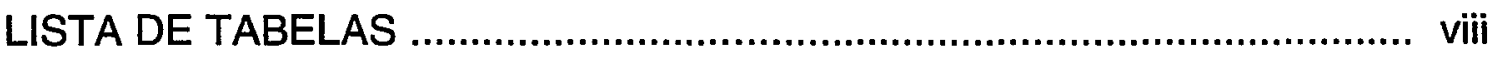

LISTA DE QUADROS ....................................................................... xiii

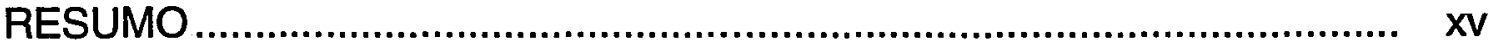

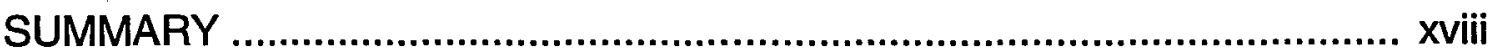

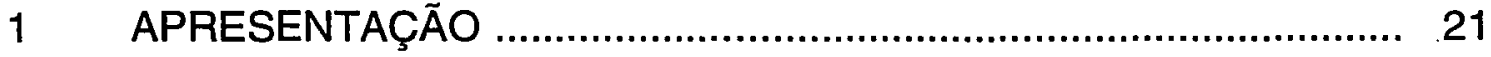

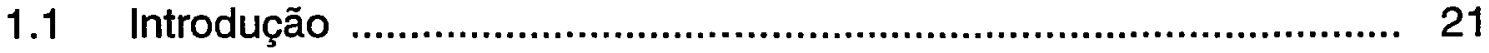

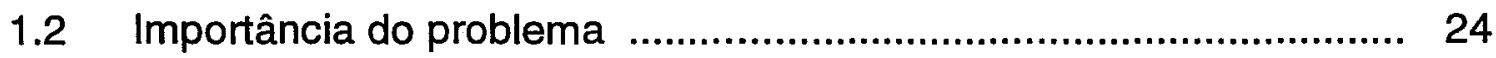

1.3 Objetivos da pesquisa f...................................................... 27

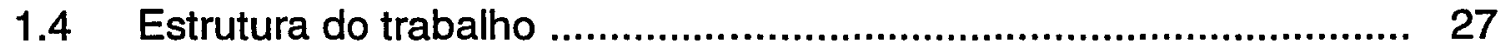

2 A ECONOMIA DA COOPERAÇĀO ....................................... 29

2.1 Concepção de sociedade cooperativa ...................................... 29

2.2 Evolução do pensamento cooperativista ...................................... 31

2.3 Tratamento teórico do cooperativismo ........................................ 35 
Página

2.4 Panorama recente do cooperativismo agropecuário mundial 41

2.5 Nova geração de cooperativas 45

2.6 Ambiente institucional do cooperativismo no Brasil 47

2.7 Problemas atuais do cooperativismo 51

3 METODOLOGIA 55

3.1 Considerações preliminares sobre o escopo da pesquisa 55

3.2 Fontes de dados utilizadas na pesquisa 56

3.3 Seleção da amostra de cooperativas agropecuárias 57

3.4 Métodos estatísticos multivariados 62

3.4.1 Análise de correspondências múltiplas 63

3.4.2 Análise de agrupamentos 66

3.4.3 Análise fatorial pelo método de componentes principais 70

3.5 Seleção das variáveis indicativas do grau de modernização da agricultura cooperativa 78

3.6 Seleção dos indicadores discriminantes das cooperativas agropecuárias da amostra 83

3.6.1 Variável 1 - Tamanho da cooperativa 89

3.6.2 Variável 2 - Endividamento da cooperativa 91

3.6.3 Variável 3 - Giro do ativo da cooperativa 
Página

3.6.4 Variável 4 - Desempenho econômico da cooperativa 92

3.6.5 Variável 5 - Fundação da cooperativa. 93

3.6.6 Variável 6-Grau de relacionamento institucional 93

3.6.7 Variável 7 - Intensidade de uso de práticas administrativas 79

3.6.8 Variável 8 - Grau de escolaridade dos dirigentes 94

4 CARACTERIZAÇÃO DA AGRICULTURA COOPERATIVA 97

4.1 Introdução 97

4.2 Características regionais da agricultura cooperativa no Brasil 98

4.3 Descrição da agricultura cooperativa nordestina 108

4.3.1 Valor da produção agropecuária cooperativa nordestina 109

4.3.2 Estrutura fundiária da agricultura cooperativa nordestina. 111

4.3.3 Condição do responsável pela exploração na agricultura cooperativa nordestina 112

4.3.4 Utilização da terra na agropecuária cooperativa nordestina 113

4.3.5 Principais lavouras cultivadas na agricultura cooperativa nordestina 113

4.3.6 Atividade pecuária na economia cooperativa nordestina 116

4.3.7 Valor adicionado da agricultura cooperativa nordestina 116 
Página

4.3.8 Pessoal ocupado na agricultura cooperativa nordestina 118

4.3.9 Assistência técnica na agropecuária cooperativa nordestina

4.3.10 Distribuição espacial do cooperativismo agropecuário nordestino 119

5 CARACTERIZAÇÃO DAS COOPERATIVAS AGROPECUÁRIAS NORDESTINAS

5.1 Análise do ambiente das cooperativas agropecuárias nordestinas

5.2 Considerações sobre as diretrizes organizacionais das cooperativas agropecuárias nordestinas

5.3 Área de atuação das cooperativas agropecuárias nordestinas

5.4 Atividades econômicas desenvolvidas pelas cooperativas agropecuárias nordestinas

5.5 Serviços prestados pelas cooperativas agropecuárias nordestinas

5.6 Canais de distribuição utilizados pelas cooperativas agropecuárias nordestinas 134

5.7 Recursos humanos nas cooperativas agropecuárias nordestinas 
Página

5.8 Desempenho financeiro das cooperativas agropecuárias nordestinas 146

5.9 Políticas de preço interno adotadas pelas cooperativas agropecuárias nordestinas 149

5.10 Apresentação do caso Camapla 155

6 DISCUSSÃO DOS RESULTADOS 161

6.1 Introdução 161

6.2 Análise de correspondências múltiplas 162

6.2.1 Determinação do número de fatores 162

6.2.2 Análise dos eixos fatoriais 164

6.2.3 Análise do primeiro plano fatorial 165

6.3 Análise de classificação 167

6.3.1 Descrição das cooperativas do grupo $A$ 168

6.3.2 Descrição das cooperativas do grupo B 171

6.3.3 Descrição das cooperativas do grupo C 174

6.3.4 Considerações finais sobre os resultados da análise de classificação 176

7 CONCLUSÕES E RECOMENDAÇÕES 179

7.1 Perfil da agricultura cooperativa brasileira 179 
Página

7.2 Situação da agricultura cooperativa nordestina 181

7.3 Conclusões 183

7.4 Recomendações de políticas para o cooperativismo 188

7.5 Considerações finais 195

ANEXOS 197

REFERÊNCIAS BIBLIOGRÁFICAS 217 APÊNDICES 


\section{LISTA DE FIGURAS}

Página

Figura 1. Esquema da classificação mista 69

Figura 2. Representação geométrica dos indivíduos e variáveis

72

Figura 3. Projeção da distância entre dois indivíduos 74

Figura 4. Representação da hiperesfera e do círculo de correlações 76

Figura 5. Coordenadas das UF no primeiro plano fatorial 105

Figura 6. Dendrograma das Unidades da Federação 106

Figura 7. Representação dos autovalores por dimensão 163

Figura 8. Representação das variáveis no primeiro plano fatorial 165

Figura 9. Representação das cooperativas no primeiro plano fatorial 166

Figura 10. Dendrograma: cooperativas 167 


\section{LISTA DE TABELAS}

Página

Tabela 1. Modalidade das dívidas das cooperativas agropecuárias no Banco do Nordeste.

Tabela 2. Perfil de liquidez da carteira de crédito cooperativo do Banco do Nordeste.

Tabela 3. Distribuição do cooperativismo agropecuário mundial

Tabela 4. Evolução do cooperativismo agropecuário no Brasil 44

Tabela 5. Valor da produção agropecuária cooperativa 109

Tabela 6. Valor da produção agropecuária cooperativa por estrato de área

Tabela 7. Valor da produção agropecuária cooperativa por atividade econômica

Tabela 8. Estabelecimentos rurais filiados a cooperativas no Nordeste

Tabela 9. Indicadores de desigualdade na estrutura fundiária da agricultura cooperativa nordestina

Tabela 10. Condição do responsável pela exploração na agricultura cooperativa nordestina

Tabela 11. Uso da terra na agricultura cooperativa nordestina 113

Tabela 12. Produção vegetal da agricultura cooperativa nordestina 114 
Tabela 13. Renda agropecuária média comparada de produtores cooperados e não-cooperados na região Nordeste

Tabela 14 Pessoal ocupado na agricultura cooperativa nordestina 118

Tabela 15. Proporção de estabelecimentos agropecuários beneficiados por serviços de assistência técnica

Tabela 16. Distribuição espacial do cooperativismo nordestino 120

Tabela 17. Valor da produção agropecuária cooperativa nordestina por Estado 120

Tabela 18. Principais oportunidades identificadas pelas cooperativas agropecuárias do Nordeste 122

Tabela 19. Principais ameaças identificadas pelas cooperativas agropecuárias do Nordeste

Tabela 20. Principais pontos fortes identificados pelas cooperativas agropecuárias do Nordeste

Tabela 21. Principais pontos fracos identificados pelas cooperativas agropecuárias do Nordeste

Tabela 22. Principais concorrentes das cooperativas agropecuárias do Nordeste 125

Tabela 23. Indicação do Relacionamento institucional mantido pelas cooperativas agropecuárias do Nordeste 126

Tabela 24. Principais objetivos organizacionais revelados pelas cooperativas agropecuárias do Nordeste 
Tabela 25. Área de atuação das cooperativas agropecuárias do Nordeste

Tabela 26. Atividade principal das cooperativas agropecuárias do Nordeste 131

Tabela 27. Composição das receitas das cooperativas agropecuárias do Nordeste 132

Tabela 28. Principais serviços prestados pelas cooperativas agropecuárias do Nordeste

Tabela 29. Critérios adotados pelas cooperativas agropecuárias do Nordeste para classificação de sócios ativos

Tabela 30. Dimensão do quadro de associados das cooperativas agropecuárias do Nordeste 140

Tabela 31. Critérios adotados pelas cooperativas agropecuárias do Nordeste para recrutamento de sócios

Tabela 32. Presença de associados de cooperativas agropecuárias do Nordeste em assembléia geral

Tabela 33. Recorrência das informações disponibilizada aos sócios 142

Tabela 34. Sistema de monitoramento do associado das cooperativas agropecuárias do Nordeste

Tabela 35. Freqüência de aplicação de sanção a associados nas cooperativas agropecuárias do Nordeste 
Tabela 36. Indicadores de desempenho financeiro das cooperativas agropecuárias do Nordeste

Tabela 37. Nível de utilização da capacidade instalada das cooperativas agropecuárias do Nordeste

Tabela 38. Política interna de preços revelada pelas cooperativas agropecuárias do Nordeste

Tabela 39. Ações realizadas, nos últimos três anos para melhorar o desempenho dos negócios das cooperativas agropecuárias do Nordeste 153

Tabela 40. Grupo A: número de associados 169

Tabela 41. Grupo A: indicadores de estrutura econômica e patrimonial 170

Tabela 42. Grupo A: composição do faturamento 171

Tabela 43. Grupo B: número de associados 172

Tabela 44. Grupo B: indicadores de estrutura econômica e patrimonial 172

Tabela 45. Grupo B: composição do faturamento 173

Tabela 46. Grupo C: número de associados 174

Tabela 47. Grupo C: indicadores de estrutura econômica e patrimonial 175

Tabela 48. Grupo C: composição do faturamento 176 
Página

Tabela 49. Comparação entre estabelecimentos agropecuários de produtores cooperados e não-cooperados no Nordeste 189 


\section{LISTA DE QUADROS}

Página

Quadro 1. Definição do tamanho amostral 60

Quadro 2. Matriz de dados condensada 64

Quadro 3. Matriz disjuntiva completa 65

Quadro 4. Valores e variância explicada pelos três primeiros autovalores

Quadro 5. Coordenadas - correlações - das variáveis nos três primeiros eixos fatoriais 100

Quadro 6. Comunalidades e contribuição total para a formação dos três eixos fatoriais 104

Quadro 7. Composição das classes regionais a partir dos eixos fatoriais

Quadro 8. Canais de distribuição utilizados pelas cooperativas agropecuárias nordestinas

Quadro 9. Destino da produção das cooperativas agropecuárias nordestinas 
Página

Quadro 10. Distribuição funcional dos recursos humanos das cooperativas agropecuárias do Nordeste por nivel de escolaridade

Quadro 11. Participação relativa da Camapla na agropecuária microrregional 155

Quadro 12. Autovalor e inércia 162

Quadro 13. Políticas públicas recomendadas para o cooperativismo 190

Quadro 14. Políticas privadas recomendadas para $\circ$ cooperativismo 


\title{
COOPERATIVISMO AGROPECUÁRIO NORDESTINO: \\ DIAGNÓSTICO E TIPOLOGIA
}

\author{
Autor: MARCOS SOARES DA SILVA \\ Orientador: Prof. Dr. MARCOS SAWAYA JANK
}

\section{RESUMO}

Com o objetivo de avaliar o cooperativismo agropecuário do Nordeste brasileiro, procedeu-se ao levantamento de dados primários em amostra de 41 cooperativas.

O trabalho de pesquisa é reforçado com elementos extraídos de tabulação especial do Censo Agropecuário 1995-1996, do Instituto Brasileiro de Geografia e Estatística (IBGE), alusivos aos estabelecimentos agropecuários filiados a cooperativas a fim de que sejam examinados aspectos referentes a padrão tecnológico, organização da produção e índices de produtividade.

Para tanto, foram construídas variáveis indicativas do grau de modernização da agricultura cooperada e discriminantes das cooperativas agropecuárias. Dada a preponderância de variáveis qualitativas, foi escolhida a técnica de análise de correspondências múltiplas para investigação dos fatores caracterizadores do perfil das organizações cooperativas estudadas. A análise fatorial pelo método de componentes principais é utilizada para descrever a agricultura cooperativa, procurando situar o Nordeste em relação ao resto do 
Brasil. Por fim, procedeu-se à construção de tipologias das cooperativas e dos espaços regionais a partir de seus principais traços sociais, econômicos e financeiros, mediante o uso de análise de agrupamentos.

Os resultados mostram que a agricultura cooperativa brasileira pode ser classificada em cinco regiōes relativamente homogêneas quanto ao grau de modernização, índices de produtividade e filiação ao cooperativismo:

- região 1: ES, GO, MG, MT, RJ - agricultura de adiantado estágio de modernização que apresenta altos índices de produtividade e moderado nível de filiação ao cooperativismo;

- região 2: $A L, B A, C E, M A, P B, P E, R N, S E$, TO - agricultura atrasada do ponto de vista tecnológico, apresentando baixos níveis de produtividade dos fatores, em especial do trabalho, e incipiente índice de filiação ao cooperativismo;

- região 3: DF, MS, SP - agricultura que apresenta os maiores índices de produtividade e de modemização do País;

- região 4: AC, AM, AP, PA, PI, RO, RR - constitui o espaço regional de agricultura mais atrasada do País, apresentando baixos níveis de produtividade, notadamente da terra;

- região 5: PR, RS, SC - agricultura com elevado nível de modernização tecnológica e filiação ao cooperativismo, cuja força de trabalho provém dominantemente da base familiar.

No âmbito organizacional, o estudo aponta evidências de que as cooperativas agropecuárias nordestinas podem ser classificadas em três grandes grupos, segundo a confluência de fatores denotativos de tamanho, 
estrutura de capital, nível de atividade econômica e desempenho empresarial, a saber:

- cooperativas de difícil recuperação - detendo estrutura operacional de pequeno porte, essas cooperativas dedicam-se predominantemente à administração de créditos de repasse a associados;

- cooperativas revitalizáveis - constituídas até a década de oitenta, essas cooperativas reúnem considerável patrimônio e exploram, em sua maioria, atividades econômicas deficitárias;

- cooperativas potencialmente dinâmicas - representando um quarto da amostra considerada, essas cooperativas possuem maior porte econômico e moderado nível de endividamento.

A análise dos ambientes interno, operacional e geral dos três grupos retro adscritos permite a identificação dos principais problemas que afetam o desempenho das cooperativas agropecuárias nordestinas.

Finalmente, com fundamento no diagnóstico realizado, propõe-se a adoção de um conjunto de políticas públicas e privadas com o objetivo de revitalizar parcela das cooperativas agropecuárias nordestinas. 


\title{
NORTHEASTERN AGRO-CATTLE-RAISING COOPERATIVISM:
}

\section{DIAGNOSTIC AND TIPOLOGY}

\author{
Author: MARCOS SOARES DA SILVA \\ Adviser: Dr. MARCOS SAWAYA JANK
}

SUMMARY:

Aiming at to evaluate the Northeastern Agro-Cattle-Raising Cooperativism, a sample of primary data of 41 cooperative has been gathered.

The research work is reinforced with information extracted from the special tabulation of the 1995-1996 agro-cattle-raising census from the Brazilian Institute of Statistics and Geography (IBGE), allusive to agro-cattle-raising establishments affiliated with cooperatives, with the purpose that technological standards, production organization and productivity indexes aspects to be examined.

For that, it has been built variables measuring the cooperative agricultural modernization degree and agro-cattle-raising cooperative discriminators. Given the preponderancy of qualitatives variables, it was chosen the multiple correspondences analysis technique for the investigation of the factors, which characterizes the profile of the studied cooperatives organizations. The method of the main components factorial analysis is used to describe the agricultural 
cooperative, trying to position the northeast in relation to the other regions of Brazil. Finally, it has been established the typology of the cooperatives and of the regional spaces, from its main social, economical and financial characteristics, through the use of analysis of grouping.

The results show that the Brazilian Cooperative Agriculture can be classified in five relatively homogeneous regions by its degree of modernization, productivity indexes and cooperatives affiliation.

- Region 1: ES, GO, ME, MT, RS - Agriculture of advanced modernization stage which shows high productivity indexes and moderate cooperativism affiliation level.

- Region 2: AL, BA, CE, MA, PB, PE, RN, SE, TO - Backward agriculture technologically speaking, showing low levels of factors productivity, especially of the working factor, and incipient cooperativism affiliation index.

- Region 3: DF, MS, SP - Agriculture that shows the highest productivity and modernization indexes of the country.

- Region 4: AC, AM, AP, PA, PI, RO, RR - It constitutes the most antiquated agriculture in the country, showing low productivity levels, mainly of the land factor.

- Region 5: PR, RS, SC - Agriculture with high level of technological modernization and cooperativism affiliation, whose work force comes mainly from the family basis.

In the organizational aspect, the study shows evidences that northeastern agrocattle-raising cooperatives can be classified in three major groups, accordingly to the confluence of factors which denote the size, capital structure, level of economic activity and entrepreneurial performance, as shown: 
- Cooperatives hard to be recovered - having small operational capacity, these cooperatives dedicate themselves, predominantly, to the administration of funds transference credit to the affiliated;

- Cooperatives able to be revitalized - constituted until the 1980's, these cooperatives gathers considerably assets and explore, mostly, unprofitable economic activities;

- Potentially dynamic cooperatives - representing one-fourth of the sample, these cooperatives have stronger economical capacity and moderate level of debt.

The analysis of internal, operational and general environments of three aforementioned groups allows the identification of the main problems, which affect the performance of the northeastern agro-cattle-raising cooperatives.

Finally, based on the realized diagnostic, it is proposed the adoption of private and public politics, with the objective of revitalization of part of the northeastern agro-cattle-raising cooperatives. 


\section{APRESENTAÇÃo}

\subsection{Introdução}

O cooperativismo agropecuário do Nordeste brasileiro desenvolveu-se, predominantemente, por meio de estímulos exógenos, conforme relatam Daniel \& Gal (1981) e Rego (1973).

Convicto de que o cooperativismo constitui vetor capaz de corrigir falhas de mercado e possui capacidade de congregar grande contingente de agricultores em torno de ações programáticas, o Estado brasileiro estimulou o seu emprego como instrumento de desenvolvimento rural, em diversos programas implantados no Nordeste (Rego, 1991).

Esta conduta encontrou justificativa nas precárias condições socioeconômicas da população rural que impediam a formação espontânea de grupos de cooperação. Sem nenhuma organização social precedente, seria praticamente impossível fazer chegar aos produtores rurais, que se encontravam dispersos, as políticas públicas de desenvolvimento rural em virtude dos custos impeditivos de implementação (Gal, 1981).

Em face disso, adotou-se a estratégia de incentivar a organização dos agricultores em cooperativas, com vistas a facilitar a disseminação de técnicas modernas de produção agropecuária e aumentar a capilaridade do sistema de crédito rural oficial (Daniel \& Gal, 1981).

As relações entre Estado e cooperativismo agrícola no Brasil são, com riqueza de informações, tratadas em Ferreira (1988) que faz competente 
incursão histórica ao analisar as principais políticas públicas implementadas a partir da década de trinta.

De acordo com Pinho (1982), entre 1940 e 1960, no Nordeste, em resposta ao apoio governamental, o número de cooperativas cresceu de 118 para 453, enquanto o quadro social evoluiu de 1.805 para 93.843 cooperados filiados. Nessa fase, a atuação do cooperativismo limitava-se ao segmento rural propriamente dito, dada a imperiosa necessidade de organizar a produção agrícola para garantir $\circ$ abastecimento alimentar das cidades, que experimentavam acelerado crescimento populacional.

Rego (1973) assinala que as cooperativas nordestinas apresentaram, em aludido período, desempenho satisfatório no suprimento de insumos agropecuários e na comercialização de produtos agrícolas.

A partir de meados da década de sessenta, inicia-se a implementação de política agroindustrial de amplo alcance, em que os instrumentos utilizados, notadamente o crédito bancário e a política de garantia de preços mínimos, dirigiam-se indistintamente aos setores agroprocessadores (Ferreira, 1988).

Nessa época, o cooperativismo nordestino passa a atuar nos primeiros estágios da agroindustrialização. Foi instalado no Nordeste considerável parque agroindustrial para processamento de produtos agrícolas primários, com destaque para o beneficiamento de arroz, algodão e fabricação de ração animal (Pinho, 1982).

A crise fiscal instaurada no País, a partir do final dos anos setenta, contribuiu para a notável redução da oferta de recursos financeiros. Assim sendo, com a escassez de linhas de crédito disponíveis, ocorreram graves problemas de liquidez que provocaram a dissolução de muitas cooperativas agropecuárias na região Nordeste. As cooperativas que sobreviveram tiveram de reduzir consideravelmente suas atividades econômicas, concentrando-se, na 
maioria dos casos, na exploração de unidades de revenda de insumos agropecuários e na prestação de serviços de mecanização agrícola (Rego, 1991).

Com a promulgação da Constituição da República de 1988, iniciou-se o período de liberalização, ou seja, de não-intervenção do Estado na criação e funcionamento das cooperativas. Dispõe o artigo $5^{\circ}$, inciso XVIII, da Carta Magna, que a criação de associações e, na forma da lei, a de cooperativas independem de autorização, sendo vedada a interferência estatal em $\cdot$ seu funcionamento (Moraes, 2000).

Acredita-se que a motivação da desativação e/ou redução de atribuições, nos últimos anos, de órgãos públicos que prestavam importantes serviços de apoio ao cooperativismo pode ser atribuída à interpretação apressada da retro citada norma constitucional, pois ao Estado persiste a responsabilidade de exercer a regulação da economia (Souza, 1999).

Ademais, cumpre destacar que o Texto Constitucional, em seu artigo 174, estatui que o Estado exercerá, na forma da lei, as funções de fiscalização, incentivo e planejamento, sendo este determinante para o setor público e indicativo para o setor privado, recomendando ainda tratamento diferenciado para o cooperativismo e outras formas de associativismo (Moraes, 2000; Lima, 1997).

A abertura ao comércio internacional e a desregulamentação das atividades econômicas, aceleradas no País a partir do início dos anos 90, são fenômenos que deram origem a amplo processo de reestruturação dos arranjos organizacionais e institucionais norteadores do relacionamento entre os agentes produtivos.

No Nordeste, nota-se que os efeitos potenciais dessas mudanças ainda não foram adequadamente compreendidos pelas lideranças cooperativistas do 
segmento agropecuário. Constituição de blocos regionais de comércio, perda de efetividade dos instrumentos tradicionais de política agrícola e tendência de concentração de capitais são temas ainda distantes para muitos que circulam no meio cooperativista.

É entendimento patente que a abertura da economia brasileira ao comércio internacional evidenciou problemas preexistentes no cooperativismo nordestino, tais como baixos níveis de produtividade, inserção mercadológica incipiente e altos custos de produção. Também, não resta dúvida de que esses ingredientes são suficientes para que as cooperativas percam rapidamente participação nos mercados agropecuários, mantido o atual estado de letargia.

Portanto, ante o cenário de acirramento da concorrência e da esperada redução da participação do Estado na economia, é imperioso que o cooperativismo agropecuário do Nordeste desperte para a necessidade de adoção de políticas privadas que promovam sua competitividade em bases empresariais auto-sustentáveis.

\subsection{Importância do problema}

Apesar da redução da intervenção estatal no setor primário em âmbito nacional, a região Nordeste teve o privilégio de contar, a partir de 1989, com fonte estável de recursos para financiamento do setor produtivo, representada pelo Fundo Constitucional de Financiamento do Nordeste (FNE), cuja administração ficou delegada ao Banco do Nordeste do Brasil (BNB).

Por volta de 1991, foi adotada a estratégia de financiar o produtor rural por intermédio de sua organização cooperativa. Esta medida tinha o objetivo de expandir a capilaridade e aumentar a capacidade operacional do Banco do Nordeste, dissipando eventuais pressões de natureza política que pusessem em risco a transferência do FNE para outros agentes financeiros. 
Nos últimos dez anos, foram realizados vultosos investimentos direcionados para a reestruturação do cooperativismo agropecuário nordestino. Segundo informações prestadas pelo Banco do Nordeste, 341 cooperativas agropecuárias absorveram recursos da ordem de $\mathrm{R} \$ 552$ milhões, a preço de janeiro de 1999.

Animados pelos estímulos então vigentes - financiamento de até $100 \%$ do plano de inversões, encargos financeiros negativos em termos reais, prazos de reembolso de até 12 anos -, os produtores erigiram cooperativas praticamente sem nenhum capital próprio, muitas das quais sem condições administrativas mínimas para funcionamento. Estima-se que $38 \%$ das cooperativas agrícolas atualmente existentes no Nordeste foram constituídas durante a década de noventa.

Conforme apresentado na Tabela 1, as cooperativas agropecuárias do Nordeste contraíram expressivo volume de dívidas em nome de seus associados, atuando em grande medida como agentes de intermediação financeira, o que revela perigoso afastamento das atividades que constituem a competência central de tais organizações.

\section{Tabela 1. Modalidade das dívidas das cooperativas agropecuárias no Banco do Nordeste.}

\begin{tabular}{lcr} 
& \multicolumn{2}{c}{ Posição: 31.1.1999 } \\
\hline Tipo de Crédito & Saldo devedor (R\$) & $\%$ \\
\hline Operação de Repasse & 425.101 .200 & 76,9 \\
Operação à Própria & 127.362 .022 & 23,1 \\
\hline Total & 552.463 .222 & 100,0 \\
\hline
\end{tabular}

Fonte: Banco do Nordeste.

Não obstante as ações empreendidas, o cooperativismo agropecuário nordestino já mostra claros sinais de debilidade. Percebe-se profundo afastamento dos associados em relação às cooperativas, indicado pela baixa 
freqüência e volume das transações internas (atos cooperativos). Parcela expressiva das cooperativas criadas ou reativadas nos anos 90 teve como clara motivação a obtenção de créditos, oferecendo pouco ou quase nenhum serviço ao associado.

Não é demais afirmar que muitos dos projetos financiados não foram adequadamente implementados, fato que, sem nenhuma dúvida, trará como conseqüência imediata a ociosidade de ativos operacionais, quer por falta ou insuficiência de matérias-primas, quer por inadequação da política comercial da cooperativa. Portanto, é notório que os benefícios até então obtidos são modestos ante o volume de recursos alocados.

Atualmente, já se apresentam manifestos problemas de liquidez nas cooperativas nordestinas que, além do endividamento relativamente elevado, dispõem de escassas fontes próprias de receitas para honrar os compromissos assumidos, pois encontram-se com suas atividades econômicas praticamente paralisadas.

Conforme exposto na Tabela 2, as obrigações vencidas das cooperativas agropecuárias no Banco do Nordeste atingem $31,7 \%$, incluídos os créditos em liquidação.

Tabela 2. Perfil de liquidez da carteira de crédito cooperativo do Banco do Nordeste.

Posição: 31.1.1999

\begin{tabular}{lrr}
\hline Situação do crédito & Saldo devedor (R\$) & $\%$ \\
\hline Não-vencido & 377.318 .636 & 68,3 \\
Atraso até 60 dias & 20.839 .637 & 3,8 \\
Atraso sup. 60 dias & 123.820 .791 & 22,4 \\
Créditos em liquidação & 30.306 .792 & 5,5 \\
Prejuízo & 177.365 & 0,0 \\
\hline Total & 552.463 .221 & 100,0 \\
\hline
\end{tabular}

Fonte: Banco do Nordeste. 
É oportuno destacar que R\$101 milhões, correspondentes a 18,3\% do estoque da carteira, representam composição ou prorrogação de dívidas, indicando que o problema do endividamento das cooperativas vem sendo postergado sem que medidas revitalizadoras sejam de fato tomadas para fins de revitalização dos empreendimentos produtivos.

\subsection{Objetivos da pesquisa}

O presente estudo tem o objetivo de realizar um diagnóstico do cooperativismo agropecuário nordestino, procurando avaliar sua importância na economia rural e agroindustrial.

Especificamente, pretende-se identificar o nível de atividade econômica das cooperativas, a base operacional dos cooperados, o perfil dos recursos humanos envolvidos, bem como verificar as relações mantidas com os principais parceiros institucionais, incluídos os produtores rurais filiados.

É também pretensão do trabalho construir uma classificação regional da agricultura cooperada e uma tipologia para as organizações cooperativas agropecuárias do Nordeste a partir de suas principais características, mediante o emprego de técnicas estatísticas adequadas.

Dessa forma, espera-se que a identificação de subgrupos homogêneos de cooperativas possibilite aos formuladores de políticas públicas e privadas condições de graduar e calibrar as intervenções, segundo as reais necessidades do público alvo.

\subsection{Estrutura do trabalho}

Além desta introdução, compõem a dissertação mais seis capítulos. O marco referencial do cooperativismo é discutido no Capítulo 2, proporcionando uma visão contemporânea da estrutura orgânica e dos problemas vivenciados pelas cooperativas. O Capítulo 3 trata do processo metodológico relativo aos 
procedimentos de levantamento e tratamento dos dados da pesquisa, apresentando os instrumentais de análise estatística multivariada (análise fatorial pelo método de componentes principais, análise de correspondências múltiplas e análise de classificação). No capítulo 4 , é feita uma incursão exploratória sobre a agricultura cooperativa em âmbito nacional, com vistas a situar a posição da região Nordeste em relação ao resto do País, a partir do exame de indicadores de organização, modernização tecnológica e índices de produtividade obtidos de tabulação especial do Censo Agropecuário 1995-1996, do Instituto Brasileiro de Geografia e Estatística (IBGE). Além disso, faz-se uso de análise tabular para descrever o perfil da agricultura cooperativa nordestina sob diversos aspectos: estrutura fundiária, condição do produtor, pessoal ocupado e principais atividades exploradas. No capítulo 5 , é feita exposição descritiva das cooperativas selecionadas e apresentado um caso de cooperativa que reflete o padrão modal do ramo agropecuário do cooperativismo do Nordeste. No capítulo 6, são discutidos os resultados da análise multivariada aplicada a variáveis caracterizadoras das cooperativas que compõem a amostra $e$ realizada uma classificação, segundo tipificação proposta no plano de trabalho. Finalmente, no Capítulo 7, são apresentadas as conclusões e recomendações da pesquisa. 


\section{A ECONOMIA DA COOPERAÇÃO}

Neste capítulo é exposta uma visão panorâmica do cooperativismo, iniciando pela discussão de elementos doutrinários e históricos presentes no processo de sua constituição. Em seguida, apresenta-se a configuração recente do cooperativismo agropecuário no mundo e no Brasil, procurando fornecer indícios de sua importância econômica. $O$ ambiente institucional $e$ as particularidades orgânicas do cooperativismo são tratadas na parte final do capítulo.

\subsection{Concepção de sociedade cooperativa}

A Aliança Cooperativa Internacional ( $\mathrm{ACl}$ ) estatui que cooperativa é uma associação autônoma de pessoas que se unem, voluntariamente, para satisfazer aspirações e necessidades econômicas, sociais e culturais comuns, por meio de uma empresa de propriedade coletiva e democraticamente gerida.

A prática cooperativa é alicerçada nos valores básicos de liberdade, democracia, eqüidade, solidariedade, pluralismo e justiça social que se materializam por intermédio de princípios prescritos pela doutrina (Schneider, 1991).

A doutrina é constituída a partir de valores e princípios conjugados a idéias gerais. $O$ valor dá origem e precede o princípio, ocupando posição superior na hierarquia da doutrina cooperativista. Os valores são peças de caráter mais estável que refletem crenças universais básicas. Os princípios 
decorrem da interpretação dos valores, podendo ser ajustados às circunstâncias impostas pelo ambiente institucional (Moura, 1973).

De acordo com Schneider (1991), os valores, enquanto padrões ou critérios para estabelecer o que deve ser considerado como desejável, assentam as bases para a aceitação ou a rejeição de normas particulares.

Portanto, com amparo nos fundamentos antes narrados, os princípios do cooperativismo vêm sendo readequados à realidade, mantendo-se inalterados os seus valores basilares.

A Aliança Cooperativa Internacional ( $\mathrm{ACl}$ ), nos Congressos de 1937 (Paris), 1966 (Viena) e 1995 (Manchester), aprovou expressivas mudanças nas diretrizes organizacionais do cooperativismo. Atualmente, em todo o mundo, as cooperativas orientam-se pelos seguintes princípios:

- adesão livre e voluntária - as cooperativas são organizações voluntárias, abertas a todas as pessoas aptas a utilizar os seus serviços e a assumir as responsabilidades como membros, sem discriminação sexual, social, política e religiosa;

- gestão democrática pelos membros - as cooperativas são organizações democráticas, controladas pelos seus membros, que participam ativamente na formulação das suas políticas e na tomada de decisões. Logo, continua em vigor o preceito do voto pessoal independente das quotas de capital investido;

- participação econômica dos membros - os membros contribuem eqüitativamente para o capital das suas cooperativas. Os retornos econômicos (sobras) serão rateados proporcionalmente ao volume de operações do sócio, podendo ser destinados ao 
desenvolvimento da cooperativa, mediante constituição de reservas indivisíveis ou aumento do capital social;

- autonomia e independência - as cooperativas são organizações autônomas, de ajuda mútua, controladas por seus membros. Caso as cooperativas firmem acordos com outras organizações, incluindo instituições públicas, ou recorram a capital externo, devem fazê-los em condições que assegurem o controle democrático pelos seus membros e mantenham sua autonomia;

- educação, treinamento e formação - as cooperativas promovem a educação e a formação dos seus membros, dos representantes eleitos e dos trabalhadores de forma que estes possam contribuir, eficazmente, para o desenvolvimento das suas cooperativas;

- intercooperação - visa a fortalecer o sistema produtivo e de distribuição, aproveitando sinergias geradas pela integração econômica;

- interesse pela comunidade - as cooperativas trabalham para 0 desenvolvimento sustentável das suas comunidades por meio de políticas aprovadas pelos membros.

Conservam-se obrigatórias para as cooperativas, sob pena de descaracterizá-las, as seguintes normas: adesão livre (porta aberta); controle democrático (voto pessoal); retomo pro rata e juro limitado. As prescrições restantes são classificadas pelos próprios doutrinadores como supérfluas, controvertidas ou insuficientes (Benecke, 1980; Franke, 1973; Irion, 1997).

\subsection{Evolução do pensamento cooperativista}

O cooperativismo desenvolveu-se no século XIX, na Europa, em meio a desajustes socioeconômicos provocados pela Revolução Industrial. França e 
Inglaterra, em razão de possuírem um capitalismo mais desenvolvido à época, constituíram o centro de irradiação da nova doutrina (Pinho, 1982).

Embora as bases filosóficas do cooperativismo tenham sido herdadas da experiência dos Pioneiros de Rochdale, não se pode perder de vista que o contexto histórico-social pelo qual passava a Europa favoreceu 0 desenvolvimento de arranjos institucionais alternativos ao liberalismo econômico então dominante (Bialoskorski Neto, 1994).

Nesse cenário de proliferação da pobreza e exploração do trabalho, floresceram idéias associativistas que exerceram influência decisiva na gênese do cooperativismo. Os mais importantes pensadores, chamados socialistas utópicos, foram Robert Owen, François Marie Charles Fourier, Philippe Joseph Benjamin Buchez e Louis Blanc. Conquanto tivessem posições diferentes para a solução dos problemas sociais da época, o ponto de convergência das discussões gravitava em torno do lucro e do direito de propriedade privada (Pinho, 1982).

Segundo Schneider (1991), Owen considerava o lucro uma injustiça e a causa de instabilidades econômicas. Basicamente, sua proposta consistia na propriedade comum dos meios de produção, situação em que os conflitos seriam suprimidos por falta de combatentes. De acordo com Medeiros (1995), a proposta de reforma estrutural de Owen não foi bem acolhida porque nem todos estavam dispostos a sacrificar seus interesses pessoais no presente em prol de um suposto benefício futuro.

Fourier, por sua vez, propunha uma associação entre capitalistas e trabalhadores que organizados em falanstérios, isolados do resto da sociedade, desenvolveriam atividades econômicas e sociais de modo autônomo. Os resultados de tal empreendimento seriam distribuídos em partes proporcionais para o trabalho, o capital e a administração. Nesse sistema de organização da 
produção, a propriedade privada não seria abolida, mas transformada em regime acionário entre as partes envolvidas (Schneider, 1991; Pinho, 1982).

Buchez, influenciado pelos ideais do liberalismo, não acolhia ajuda governamental de nenhum modo. Para ele, os pretensos associados deveriam reunir suas poupanças em um fundo comum e adquirir instrumentos de trabalho. A remuneração dos integrantes da organização dar-se-ia de acordo com sua atividade produtiva, reservando-se parcela indivisivel e inalienável que seria retida para a realização de novos investimentos em bens de capital (Pinho, 1982).

Blanc defendia a tese de que o capitalismo recém-implantado havia tirado do trabalhador os meios de produção. Por esta razão, propunha que 0 Estado financiasse a estruturação de organizações produtivas que seriam exploradas coletivamente pelos trabalhadores (Pinho, 1982). Diferentemente dos demais, Blanc pregava que os resultados econômicos deveriam ser distribuídos em partes iguais entre os membros da associação, independentemente das habilidades e esforços empreendidos por cada um (Schneider, 1991).

Feitas essas digressões, infere-se que o cooperativismo surgiu como alternativa a desajustes de natureza econômica e social. O marco histórico desse movimento ocorre em dezembro de 1844, quando 28 tecelōes desempregados fundam, com pequena poupança, um armazém cooperativo. As regras estatutárias dessa cooperativa de consumo deram origem aos princípios do cooperativismo hoje conhecidos (Pinho, 1982; Schneider, 1991; Bialoskorski Neto, 1994; Medeiros, 1995).

Basicamente, a proposta dos Probos Pioneiros de Rochdale consistia, em primeira etapa, na formação de capital e exploração da atividade de distribuição de bens de consumo final. Numa fase seguinte, seriam desenvolvidas atividades industriais com o objetivo de tornar o sistema 
cooperativista auto-suficiente e universal. Portanto, tratava-se de um programa de ampla reforma social.

No final do século dezenove, Charles Gide reúne as informações disponíveis a respeito das diversas experiências associativistas e as consolida. Após muita discussão, que chega a durar cerca de cinco anos, é fundada a Aliança Cooperativa Internacional $(\mathrm{ACI})$ e com ela as bases doutrinárias do cooperativismo (Pinho, 1992).

A partir de então, duas correntes de pensamento cooperativista antagonizaram-se. A primeira delas, formada pelos idealizadores da democracia cooperativista (macrocooperativismo), intencionava reformar a ordem econômico-social. A outra corrente ideológica (microcooperativismo) tinha propósitos menos ambiciosos, pois buscava tão-somente corrigir falhas de mercado em espaços geoeconômicos localizados.

A história revela que a pretensão de promover grandes reformas na economia, por intermédio do cooperativismo, não prosperou em virtude da ausência de referenciais normativos capazes de explicar como seriam tratadas as questões alocativas e distributivas em âmbito sistêmico (Benecke, 1980).

Em face disso, o cooperativismo seguiu durante muito tempo sem instrumental teórico que orientasse seu posicionamento no mercado. $O$ chamado modelo de cooperação global não se preocupava com a capacidade competitiva das cooperativas em sua inserção na economia. Segundo Benecke (1980), essa situação criou a falsa impressão de que, esteado apenas em elementos doutrinários, o cooperativismo seria a solução para muitos males, quando constitui tão-só mais um instrumento de organização socioeconômica. Boettcher (1976) reforça que essa postura é responsável pelo despreparo e fracasso de muitas organizações cooperativas. 


\subsection{Tratamento teórico do cooperativismo}

Nos últimos anos, vêm sendo desenvolvidos instrumentais teóricos que tentam explicar o cooperativismo sob a perspectiva econômica e administrativa. As contribuições da economia normativa têm confirmado muitos postulados da doutrina e recomendado certos ajustes que, aparentemente, parecem negar a própria concepção do movimento cooperativista. Entre as novas teorias cooperativistas, merecem destaque a abordagem econômica neoclássica e os estudos desenvolvidos pela Escola de Münster.

Pinho (1982) ${ }^{1}$ apresenta os principais autores que utilizaram instrumentais da economia neoclássica para explicar o comportamento da empresa cooperativa, a saber:

- François-Albert Angers - canadense que escreveu "La Coopération de la Realité à la Théorie Economique" e "Activité Coopérative en Théorie Economique" (1976) - Este autor tenta adaptar os instrumentos da teoria neoclássica para analisar a economia cooperativista sob o enfoque de sistemas e estruturas;

- Claude Pichette - canadense que escreveu "Analyse Microeconomique et Coopérative" (1972) - analisa as relações entre cooperativas, associados e mercado e compara estas organizações com as empresas de capital, demonstrando que nas primeiras os efeitos alocativos dos recursos e da repartição. das rendas são superiores;

- Isaac Guelfat - professor da Faculdade de Ciências da Universidade Hebraica de Jerusalém - aplica a teoria "welfarista"

' PINHO, D. B. O pensamento cooperativo e o cooperativismo brasileiro. São Paulo: CNPq, 1982 $272 p$. 
(Teoria do Bem-estar) como base de fundamentação da economia cooperativista, dado que na cooperativa certo número de pessoas busca melhorar sua renda em relação à condição anterior, sem prejuizo de terceiros estranhos ao grupo cooperativo;

- Claude Vienney - francês autor de "Socio-Economie des Organisations Coopératives" (1980) - estuda o funcionamento das cooperativas em sistemas econômicos diferentes;

- Serge Koulytchizky - professor da Universidade de Bordeaux, escreveu "Nouveaux Instruments d'Ánalyse des Coopératives" (1980) - obra em que discorre sobre diversos aspectos administrativos das organizações cooperativas, indicando que tais empresas ao crescerem tornam-se complexas e que o processo de democracia interna, que inerentemente é lento, pode trazer problemas relacionados à agilidade exigida em ambientes competitivos.

A Teoria de Münster ou Teoria Econômica da Cooperação foi desenvolvida na Alemanha e divulgada na América Latina a partir da década de 70. Os pressupostos básicos dessa teoria podem ser resumidos nos seguintes pontos:

- a cooperação não exclui o interesse pessoal nem a concorrência;

- o associado busca satisfazer seu interesse individual através da cooperação quando constata que a ação isolada the é desfavorável;

- a cooperativa desenvolve atividades econômicas complementares às unidades produtivas de seus sócios; 
- a lealdade de grupo resulta de contrato em que estão definidas as bases do relacionamento econômico.

Assim sendo, as organizações cooperativas são constituídas pela reunião de pessoas que defendem seus interesses econômicos individuais por meio de uma empresa que elas mantêm conjuntamente (Boettcher, 1976). Ademais, o acordo de constituição da cooperativa não implica perda de autonomia econômica das unidades individuais dos sócios.

A razão que conduz a filiação do produtor rural a uma agremiação cooperativa, alocando capitais em empreendimento coletivo, está na possibilidade de utilizar-se dos serviços disponibilizados por esta sociedade, com vistas a melhorar sua situação econômica (Franke, 1973).

Considerando que a cooperativa é vista como unidade produtiva, a Teoria da Firma pode ser adaptada para explicar o comportamento desse tipo de organização. Helmberger \& Hoos (1962) demonstram que as cooperativas procuram maximizar a prestação de serviços ao associado para que este possa tornar máxima a sua função de utilidade.

Schmiesing (1989) aproveita as mesmas pressuposições básicas feitas pelos autores retro citados, porém considera que as cooperativas poderão ter outros objetivos além da maximização dos preços recebidos pelos produtores associados. Assumindo que a cooperativa é um processador monopsonista, podem estar presentes os objetivos seguintes: maximização do preço pago ao produtor, maximização da renda líquida do produtor e operação em nível de custo, dependendo da política de preço adotada.

Para Sexton (1986), a coordenação horizontal das economias dos associados pode conduzir a um maior nível de utilidade para o conjunto dos associados da cooperativa. Considerando que a utilidade é transferível entre os agentes e que estes são avessos ao risco, esse autor propõe o seguinte 
modelo, em que $U$ representa o nível de utilidade e $U(i)$ a máxima utilidade da integração individual do produtor $\mathbf{i}$.

$$
U[(i) U(j)]>U[(i)]+U[(j)]
$$

Portanto, o nível de utilidade para a totalidade dos agricultores será maior quando estes estão organizados por meio de cooperativas, comparada à situação em que estes atuam isoladamente. Contudo, cabe ponderar que a cooperação, embora constitua condição necessária, não garante maior nivel de utilidade de cada sócio isoladamente em virtude da possibilidade de comportamentos oportunistas.

Bialoskorski Neto (1994), constata, em trabalho empírico, que para cada $10 \%$ de incremento no número de cooperados no estado de São Paulo, há provável aumento de $2,5 \%$ na renda média dos produtores agrícolas, indicando que a condição de estar associado a cooperativas é fator significativo para o aumento do seu nível de utilidade, conforme previsto por Sexton (1986).

Os argumentos até aqui expostos conduzem ao entendimento de que não há contradição ou mesmo incompatibilidade entre o cooperativismo e o regime econômico capitalista, visto que nas transações internas entre associado e cooperativa permanecem inalterados os pressupostos da maximização dos resultados econômicos das unidades produtivas individuais.

Por outro lado, importa destacar que as relações econômicas entre cooperativa e terceiros processam-se de acordo com os mecanismos de competição praticados no mercado, isto é, não se confundem com as práticas recomendadas pela doutrina cooperativista (Pinho, 1977).

Portanto, a avaliação de uma organização cooperativa deve considerar duas vertentes: a primeira de natureza econômica, em que os instrumentos de análise seriam semelhantes aos aplicados às demais empresas (produtividade, custos de produção, preço, qualidade, capacidade financeira etc.); a outra de 
cunho social, em que deve ser examinada a sua efetividade no que diz respeito à contribuição para o desenvolvimento socioeconômico do associado (adequação e suficiência dos serviços prestados, difusão de técnicas de produção, inserção em novos mercados, distribuição de sobras etc.).

Benecke (1980), tratando das condicionantes para o êxito da organização cooperativa, pondera que o cumprimento de seus objetivos sociais é condicionado pelos resultados econômicos. Na visão do referido autor, as regras do mercado, a política econômica e as diversas faces da legislação de regulamentação são os elementos que determinam a sobrevivência ou não da cooperativa.

Observa-se que as cooperativas dos países desenvolvidos têm incorporado estratégias empresariais de desenvolvimento, enfatizandó os fatores de ordem econômica. Ao contrário, nos países em desenvolvimento, entre os quais se inclui o Brasil, tem predominado interpretação indevida dos princípios doutrinários para justificar a adoção de condutas inadequadas, muitas vezes apartadas da realidade do ambiente em que atua a cooperativa.

A cooperativa é uma empresa de prestação de serviços a seus cooperados. Portanto, somente deve procurar excedentes à medida que deles precisar para garantir, em longo prazo, a ampliação da oferta de serviços aos seus membros. Esta linha de argumentação fundamenta-se na premissa de que o lucro do produtor deve ser buscado através de sua própria unidade produtiva.

Benecke (1980) afirma que a única distinção entre cooperativa e empresa de capital encontra-se no fato de que, na primeira o associado é simultaneamente dono e usuário. Todos os demais fatores envolvidos nas regras ou princípios do cooperativismo seriam insuficientes para distinguir uma cooperativa dos demais tipos societários existentes. 
Portanto, como o associado é ao mesmo tempo usuário e proprietário de seu empreendimento, esse pode implementar ações oportunistas, em que o indivíduo é beneficiado em detrimento da empresa cooperativa (Bialoskorski Neto, 1998a).

Assim sendo, partindo do suposto de que os objetivos sociais somente podem ser cumpridos na presença de sucesso econômico, Bialoskorski Neto (1998a) inicia importante discussão sobre a necessidade de as cooperativas adotarem instrumentos de gestão profissional, notadamente para monitorar as transações internas da cooperativa.

Tratando de aspectos relacionados à administração de empresas, Eschenburg (1988) discute como se dão as decisões no âmbito da cooperativa. De fato, as decisões conjuntas são mais dispendiosas. Além disto, as decisões colegiadas são mais ricas em pequenos grupos, perdendo eficácia em organizações maiores e mais complexas. Evidentemente, além dos custos convencionais com deslocamento, discussão etc., há que se considerar o custo de oportunidade. No mundo competitivo as decisões devem ser oportunas, sob risco de incorrer-se em perdas não recuperáveis.

Em geral, a cooperativa incorpora complexidades bem maiores que as existentes nas empresas de capital em virtude de seu caráter democrático. Assim, é de esperar que poucos associados reúnam condições técnicas para dirigir a cooperativa. Entre os poucos associados que possuam tais atributos, é prudente lembrar que, à medida que seus próprios negócios se desenvolvem, o custo de oportunidade destes se eleva. Por esta razão, recomenda-se que a administração de cooperativas seja conduzida por técnicos e gerentes profissionais, podendo seu recrutamento dar-se no interior da própria cooperativa, se disponível, ou no mercado. É o primeiro estágio em busca da separação entre propriedade e controle. 


\subsection{Panorama recente do cooperativismo agropecuário mundial}

A cooperativismo encontra-se presente em países de diferentes regimes econômicos e estágios de desenvolvimento econômico.

Conforme apresentado na Tabela 3 , as cooperativas agropecuárias européias representam cerca de $39 \%$ das filiações ao cooperativismo e $47,7 \%$ do faturamento mundial das cooperativas. Em média, tais organizações possuem 362 associados, cuja renda bruta anual é da ordem de US\$11, 2 mil.

Tabela 3 - Distribuição do cooperativismo agropecuário mundial.

Valores em US\$

\begin{tabular}{|c|c|c|c|c|c|c|c|c|c|}
\hline Continente & Assoc(A). & $\%$ & Coop.(B) & $\%$ & Fat. $(C)^{2}$ & $\%$ & A/B & $\mathrm{C} / \mathrm{B}^{3}$ & $C / A^{4}$ \\
\hline Europa & 19.288.023 & 38,9 & 53.315 & 25,8 & 215.600 & 47,7 & 362 & 4,0 & 11,2 \\
\hline Ásia & 17.463 .748 & 35,3 & 118.365 & 57,4 & 118.200 & 26,1 & 148 & 1,0 & 6,8 \\
\hline Américas & 6.001 .492 & 12,1 & 12.249 & 5,9 & 104.500 & 4,3 & 490 & 8,5 & $.17,4$ \\
\hline África & 6.649 .180 & 13,4 & 22.226 & 10,8 & 8.600 & 1,9 & 299 & 0,4 & 1,3 \\
\hline Oceania $^{5}$ & 100.090 & 0,2 & 151 & 0,1 & 5.500 & 1,2 & 663 & 35,6 & 53,7 \\
\hline TOTAL & 49.520 .533 & 100,0 & 206.306 & 100,0 & 452.300 & 100,0 & 240 & 2,2 & 9,1 \\
\hline
\end{tabular}

Fonte: Côté et al. (1995).

Segundo Côté et al. (1995), as cooperativas americanas possuem, em média, 490 sócios que detêm renda de US\$17,4 mil. Cabe destacar o bloco da Oceania, cuja média de sócios alcança 663 por cooperativa e renda superior a US\$ 53,7 mil. As cooperativas asiáticas têm média de 148 sócios e renda de US\$ 6,8 mil. As cooperativas africanas têm média de 299 sócios e o mais baixo nível de renda (US\$1,3 mil).

No Canadá, as cooperativas desempenham importante papel na economia. Segundo dados da Secretaria de Agricultura, do governo canadense, em 1995, as 808 cooperativas agropecuárias movimentaram negócios da

\footnotetext{
${ }^{2}$ Valores em US\$ bilhões.

${ }^{3}$ Valores em US\$ milhōes.

${ }^{4}$ Valores em US $\$$ mil.

${ }^{5}$ Inclui dados apenas parciais da Austrália.
} 
ordem de US\$11,8 bilhões. A participação das cooperativas canadenses no mercado varia de $4 \%$ (ovos) a $59 \%$ (grãos e oleaginosas). Outros exemplos: frutas $15 \%$, carne bovina $17 \%$, carne de porco $20 \%$, avicultura $47 \%$, leite $57 \%$. Referidas organizações congregam cerca de 600 mil cooperados que detêm renda anual média de US\$15,4 mil (Côté et al., 1995).

As cooperativas canadenses não escapam ao fenômeno da concentração de capitais, em especial as que atuam no setor leiteiro. Nos últimos vinte anos, o número de produtores de leite reduziu-se em 2/3, enquanto a produção ficou estabilizada em 7 bilhões de litros anuais. Entre 1977 e 1996, reduziu-se em 52\% o número de cooperativas do setor de laticínio (Côté et al., 1995).

$\mathrm{Na}$ Europa, as cooperativas exercem importante papel no setor agrícola. No segmento de grãos, por exemplo, as cooperativas francesas e alemãs controlam $71 \%$ e $50 \%$, respectivamente, das atividades de processamento e distribuição. Na Dinamarca, as cooperativas são responsáveis pela produção de $90 \%$ da carne de porco e $70 \%$ da produção de ovos. $\mathrm{Na}$ Irlanda, controlam $65 \%$ de todo o comércio de carnes. No setor leiteiro, as cooperativas da Dinamarca, Irlanda, Holanda e Alemanha dominam mais de $50 \%$ do mercado. Nos demais países que constituem a União Européia, as cooperativas agrícolas detêm expressiva participação no mercado agropecuário, respondendo por cerca de 35\%. (Mauget \& Declerck, 1996).

Exceção feita à Espanha, onde as cooperativas são pequenas e diversificadas, o número de cooperativas na Europa vem declinando. A redução do número de cooperativas é explicada pela adoção da estratégia de concentração de capitais, a fim de viabilizar a obtenção de ganhos de escala. Na França, $10 \%$ das cooperativas são responsáveis por $67 \%$ do faturamento do segmento cooperativista. No Reino Unido, $18 \%$ das cooperativas controlam $85 \%$ das vendas realizadas por cooperativas rurais (Mauget \& Declerck, 1996). 
Quanto à estratégia competitiva, existem arranjos muito diversificados. $\mathrm{Na}$ Holanda e Dinamarca, as cooperativas são mais especializadas em determinado produto ou atividade, com preferência pela integração para trás. No Reino Unido, as cooperativas são focadas no segmento agrícola propriamente dito, envolvendo-se muito pouco com atividades de processamento de matérias-primas. As cooperativas irlandesas são polivalentes, atuando em mais segmentos produtivos para frente e para trás com o intuito de adicionar valor ao seu negócio. Na Espanha, as cooperativas são diversificadas, trabalhando simultaneamente com enorme variedade de produtos, tais como frutas, legumes, vinhos e oleaginosas. São cooperativas de pequeno e médio portes, portanto pouco concentradas, e que possuem irrelevante participação no segmento agroindustrial. Já as cooperativas francesas atuam em toda a cadeia alimentar, cabendo ressaltar que são polivalentes tanto em modalidade de produtos como em atividades relacionadas ao longo do processo produtivo (Mauget \& Declerck, 1996).

No Brasil, algumas cooperativas agropecuárias acompanharam a tendência da economia mundial de expandir-se, mediante a concentração de capital. Com esta estratégia, busca-se obter ganhos de escala, conquistar novos mercado e compensar falhas na estrutura de mercado.

Contudo, a maioria das cooperativas agropecuárias brasileiras é bastante atomizada e precariamente integrada, não contando as singulares com centrais ou federações suficientes que Ihes forneçam, adequadamente, serviços complementares ou as represente politicamente. Até mesmo nas regiōes Sul e Sudeste, onde o cooperativismo é mais disseminado, existem poucas organizações de segundo e terceiro graus.

$\mathrm{Na}$ Tabela 4, apresenta-se a evolução do cooperativismo agropecuário, por macrorregiões brasileiras: 
Tabela 4. Evolução do cooperativismo agropecuário no Brasil.

I - Número de cooperativas

\begin{tabular}{lrrrrrr}
\hline Região/ano & 1940 & 1950 & 1960 & 1970 & 1980 & 1997 \\
\hline Sudeste/Sul & 402 & 835 & 1.188 & 830 & 982 & 746 \\
Nordeste & 118 & 296 & 453 & 248 & 408 & 468 \\
Norte/Centro-Oeste & 10 & 60 & 98 & 82 & 90 & 196 \\
\hline Brasil & 530 & 1.191 & 1.739 & 1.160 & 1.480 & 1.410 \\
\hline
\end{tabular}

II - Número de associados

\begin{tabular}{lrrrrrr}
\hline Região/ano & 1940 & 1950 & 1960 & 1970 & 1980 & 1997 \\
\hline Sudeste/Sul & 44.703 & 118.060 & 304.210 & 605.607 & 737.528 & 773.997 \\
Nordeste & 1.805 & 25.247 & 93.843 & 130.200 & 170.517 & 94.409 \\
Norte/Centro-Oeste & 382 & 1.835 & 8.433 & 23.326 & 39.272 & 55.219 \\
\hline Brasil & 46.890 & 145.142 & 406.486 & 759.133 & 947.317 & 923.625 \\
\hline
\end{tabular}

III - Número médio de associados

\begin{tabular}{lrrrrrr}
\hline Região/ano & 1940 & 1950 & 1960 & 1970 & 1980 & 1997 \\
\hline Sudeste/Sul & 111 & 141 & 256 & 256 & 1.306 & 1.038 \\
Nordeste & 15 & 85 & 207 & 525 & 418 & 202 \\
Norte/Centro-Oeste & 38 & 31 & 86 & 86 & 436 & 282 \\
\hline Brasil & 88 & 122 & 234 & 654 & 1.160 & 655 \\
\hline
\end{tabular}

Fontes: Os dados até 1980 foram extraídos de Pinho, D.B. O pensamento cooperativo e o cooperativismo brasileiro. In: Manual do Cooperativismo, v.1. São Paulo: CNPq, 1982; os dados de 1997 foram fornecidos pela Organização das cooperativas Brasileiras.

Essas organizações atuam principalmente nos setores de laticínios, café, arroz, soja, algodão e carne de suínos (OCB, 1997). Embora em menor escala, as cooperativas também atuam na indústria de insumos, produzindo fertilizantes, rações e sementes.

Estima-se que as cooperativas agropecuárias brasileiras possuam faturamento da ordem de $R \$ 13,3$ bilhões, detendo participação expressiva na comercialização das seguintes commodities: algodão (39\%), arroz (11\%), soja $(29 \%)$, milho $(17 \%)$ e feijão (11\%). Os empregos gerados situam-se em torno de 112 mil (Lopes et al., 1997). 


\subsection{Nova geração de cooperativas}

O modelo de nova geração de cooperativas difere da forma tradicional de cooperativas agrícolas em vários aspectos, permitindo alcançar a integração horizontal e vertical da produção, de forma a racionalizar o fluxo de produção de acordo com os sinais de mercado. Segundo Stefanson et al. (1995) \& Cropp (1996), citados por Nilsson (1997), as diferenças mais relevantes são as seguintes:

- existência de compromisso contratual em que são estabelecidos os direitos de os associados entregarem certa quantidade de produto com qualidade especificada;

- associação de um grupo fechado de cooperados em área selecionada, que orientam sua produção ao atendimento de demandas bem definidas;

- em razão da estratégia de adicionar valor ao produto, os investimentos necessários às atividades de produção e marketing são rateados proporcionalmente ao uso programado que 0 associado fará do negócio coletivo. Estima-se que $40 \%$ a $50 \%$ do capital dessas cooperativas sejam próprios;

- devido ao fato de o sistema de associação ser fechado, as ações (contratos de entrega) são negociáveis. Em conseqüência, existe um mercado secundário para tais ações e seu valor pode variar, de acordo com as expectativas que se faça a respeito da performance da cooperativa;

- como estas cooperativas trabalham em segmentos de mercado mais estreitos, há pouca heterogeneidade entre os sócios; 
- as cooperativas de nova geração são geridas por administradores contratados e recebem apoio consultivo de profissionais altamente qualificados;

- para evitar que eventualmente algum membro venha a dominar a cooperativa, há limitação do número de ações que podem ser adquiridas por um único associado;

- os benefícios do empreendimento são distribuídos de acordo com o volume de negócios de cada sócio. Porém, como este é vinculado ao aporte de capital para constituição do investimento, na prática é como se a remuneração fosse proporcional ao capital investido;

- em geral, os excedentes econômicos são distribuídos ao final do exercício. As necessidades futuras de capital da cooperativa devem ser supridas por aportes adicionais de capital ou por captação externa.

O desenvolvimento das cooperativas de nova geração tem-se concentrado em North Dakota, Minnesota e Wisconsin, nos Estados Unidos, desde o início da década de 80 . Nos últimos anos, referido movimento expandiu-se para o Canadá. Até o momento, não se registram dificuldades ou casos de fechamento de cooperativas da espécie (Cook, 1997).

Segundo Bialoskorski Neto (1998b), o modelo de cooperativas de nova geração supera problemas relacionados à ação de oportunistas e à capitalização, ora enfrentados por cooperativas tradicionais, visto que as suas ações são negociáveis. As transações operacionais entre cooperados e cooperativa são mais estáveis, devido também ao fato de que o associado não se preocupa apenas com os preços pagos e recebidos em curto prazo, mas com a valorização do empreendimento coletivo em horizonte mais largo. 
De maneira idêntica, os problemas derivados da propriedade comum, que poderiam ser substanciais em muitas cooperativas tradicionais, não se verificam nas cooperativas de nova geração em razão de que são impostos estreitos limites contratuais e de que a empresa possui uma cotação no mercado.

Há que se considerar que são poucos os problemas atinentes à definição do negócio e à escolha das áreas de destinação das inversões produtivas. Isto se dá porque as cooperativas de nova geração atuam focadas em mercados bem definidos e trabalham com poucos produtos. Ademais, como os produtores são bastante homogêneos quanto ao tamanho, não existe espaço para divergências consideráveis.

Finalmente, o núcleo dos associados de uma cooperativa de nova geração tende a ser composto dos melhores produtores localizados na base territorial em que atua a cooperativa.

\subsection{Ambiente institucional do cooperativismo no Brasil}

O cooperativismo surgiu no Brasil no final do século dezenove sob influência da doutrina rochdaleana. Em 1891, foi fundada a Associação Cooperativa dos Empregados da Companhia Telefônica, no município de Limeira, São Paulo. Três anos depois, no Rio de Janeiro, era constituída a Cooperativa Militar de Consumo (Pinho, 1982).

A legislação brasileira recepcionou os princípios cooperativistas estabelecidos pela Aliança Cooperativa Internacional ( $\mathrm{ACl}$ ), conferindo a essas sociedades adequado tratamento de sua disciplina jurídica (Bulgareli, 1998).

O Decreto $\mathrm{n}^{\circ} 22.239$, de 1932 , foi o primeiro diploma legal a abordar o cooperativismo no Brasil, regulando as práticas da cooperação já existentes. Com essa iniciativa, o legislador consagra no plano jurídico os princípios 
rochdaleanos de gestão democrática, adesão livre, pagamento de juros limitados ao capital, singularidade de voto, retorno de excedentes econômicos proporcionais às operações (Pinho, 1982; Bulgarelli, 1998).

Os atos normativos estatais impuseram, entre 1932 e 1988, muitas restrições à criação e funcionamento das cooperativas, chegando ao extremo de intervir diretamente na gerência dessas organizações. Contudo, segundo Ferreira (1988), o aparelho estatal concentrou seus esforços em ações de fiscalização e controle, negligenciando a formação de recursos humanos. De certo, esta conduta inibiu o desenvolvimento de lideranças capazes de formar um cooperativismo em bases empresariais autônomas.

$\mathrm{Na}$ Constituição brasileira em vigor, promulgada em 5 de outubro de 1988, há diversos dispositivos que tratam das cooperativas:

- o artigo $5^{\circ}, \mathrm{XVIII}, \mathrm{CF}$, que dispõe sobre autonomia, preconiza que a criação de associações e, na forma da lei, a de cooperativas independem de autorização, vedada a interferência estatal em seu funcionamento;

- o artigo 146, III, CF, que prevê adequado tratamento tributário ao ato cooperativo praticado pelas sociedades cooperativas;

- o artigo 174 , parágrafo $2^{\circ}, \mathrm{CF}$, estatui que a lei apoiará e estimulará o cooperativismo e outras formas de associativismo;

- o artigo 187, que trata da política agrícola nacional, destaca o cooperativismo entre os agentes participantes de sua formulação e execução;

- o artigo 192, dispõe sobre a participação das cooperativas de crédito no sistema financeiro nacional. 
Atualmente, as cooperativas brasileiras estão disciplinadas pela Lei $n^{\circ}$ 5.764, de 16.12.1971, parcialmente recepcionada pela Constituição da República de 1988. Segundo imperativo legal, cooperativas são sociedades de pessoas, com forma e natureza jurídica próprias, de natureza civil, não sujeitas a falência, constituídas para prestar serviços aos associados, distinguindo-se das demais sociedades pelas seguintes características:

- adesão voluntária, com número ilimitado de associados, salvo impossibilidade técnica de prestação de serviços;

- variabilidade do capital social representado por quotas-partes;

- limitação do número de quotas-partes do capital para cada associado, facultado, porém, o estabelecimento de critérios de proporcionalidade, se assim for mais adequado para o cumprimento das obrigações;

- inacessibilidade das quotas-partes do capital a terceiros, estranhos à sociedade;

- singularidade de voto, podendo as cooperativas centrais, federações e confederações de cooperativas, com exceção das que exerçam atividade de crédito, optar pelo critério de proporcionalidade;

- quorum para funcionamento e deliberação da assembléia geral baseado no número de associados;

- retorno das sobras líquidas do exercício proporcionalmente às operações realizadas pelo associado, salvo deliberação em contrário da assembléia geral;

- indivisibilidade dos fundos de reservas e de assistência técnica educacional e social. 
$\mathrm{O}$ artigo terceiro do retro citado diploma legal estabelece que celebram contrato de sociedade cooperativa as pessoas que reciprocamente se obrigam a contribuir com bens ou serviços para o exercício de uma atividade econômica, de proveito comum sem objetivo de lucro.

Relativamente a essa norma, Bulgarelli (1996) chama a atenção para a referência ao exercício de atividade econômica que pressupõe a organização dos fatores de produção. Portanto, em que pese o seu caráter civil, as organizações cooperativas são empresas. Martins (1999) define empresa como um organismo utilizado para o exercício da atividade econômica.

A acepção da dimensão empresarial das cooperativas, à luz do direito positivo, é discutida em Franke (1973) e, posteriormente, em 1995, ratificada pela Aliança Cooperativa Internacional $(\mathrm{ACl})$ que, em atitude inédita, apresenta explicitamente o conceito de cooperativa.

Em face das suas características próprias, que não se confundem com outros tipos societários, o relacionamento do cooperado com a cooperativa, na obtenção dos serviços indispensáveis à materialização e coletivização da atividade econômica, constitui o ato cooperativo (Lima, 1997).

De conformidade com o ordenamento do País, o ato cooperativo não implica operação de mercado, nem contrato de compra e venda de produto ou mercadoria, mas sim a realização de um serviço social. Por esta razão, as cooperativas são beneficiadas com isenções fiscais, cujos limites e condições são estabelecidos nos diplomas normativos que tratam de cada tributo.

A lei brasileira, ao conceituar o ato cooperativo, só reconhece como tal os atos praticados entre as cooperativas e seus associados, entre estes e aquelas e pelas cooperativas entre si, desde que associadas e, ainda, quando visarem exclusivamente a seus objetivos sociais. 
Portanto, as operações com terceiros, embora admitidas pela legislação, são consideradas como fatos eventuais e acessórios, contrariando a realidade imposta pela ordem econômica hodierna. A propósito do escopo do ato cooperativo, Becho (1997) relata que o direito positivo e a jurisprudência de importantes países europeus e da Argentina abonam como tal as operações realizadas pelas cooperativas com outras pessoas (físicas ou jurídicas).

\subsection{Problemas atuais do cooperativismo}

Por muitos anos, o paternalismo das agências governamentais, na ação de indução do sistema cooperativista brasileiro, encobriu deficiências estruturais, tornadas públicas com a redução do papel do Estado na economia, nos anos noventa. Os generosos subsídios concedidos no passado foram responsáveis pela realização de investimentos em projetos de baixa taxa de retorno econômico e pela expansão do território de atuação das cooperativas. $A$ abertura de novas frentes de atividades, por vezes, de interesses de minorias, mas com o patrocínio de toda a coletividade, concorreu para o gigantismo empresarial, sem o suporte de estruturas administrativas adequadas.

A equivocada interpretação do princípio "controle democrático pelos sócios", que dificulta a implementação da separação entre propriedade e controle, conduz a uma situação em que empreendimentos de alta complexidade sejam dirigidos por pessoas que não reúnem os atributos mínimos exigidos ao exercício da função.

Assim sendo, é freqüente a existência de diretorias executivas que atuam em tempo parcial e que não detêm adequado domínio sobre os negócios da cooperativa.

É importante acentuar que a profissionalização da gestão é contingenciada, em muitos casos, pelo reduzido porte das atividades 
econômicas exploradas pela cooperativa que não geram excedentes suficientes para remunerar administradores profissionais.

As cooperativas, por explorarem múltiplas atividades e serem constituídas por agricultores heterogêneos entre si, quanto ao porte econômico e nível tecnológico empregado, geralmente apresentam sérios problemas de condução de seus negócios visto que lidam com interesses não convergentes.

O cooperativismo convive atualmente com crise de natureza ideológica e financeira, enfrentando ainda problemas de dimensionamento e de funcionamento.

Não é incomum a existência de cooperativas que, mesmo apresentando maior grau de eqüidade e participação, são incapazes de proporcionar adequados serviços aos associados em razão de atuar em espaços econômicos marginais e com precária capacidade empresarial.

Conforme previra Franke (1973), fica cada vez mais evidente que a prática associativista não constitui privilégio das organizações cooperativistas: as empresas de capital, hoje mais do que nunca, buscam parcerias que contribuam para a racionalização dos fluxos de produção e distribuição de mercadorias: os consórcios e a integração entre agroindústrias, empresas que operam atividades de distribuição e produtores rurais constituem uma realidade até pouco tempo não imaginada pelas cooperativas.

Tendo em vista que princípios doutrinários recomendam limites ao pagamento de juros ao capital, as cooperativas têm dificuldade de atrair os recursos financeiros necessários ao seu crescimento e à sua atualização tecnológica. 
Por outro lado, como os sócios são donos e usuários da cooperativa, estes procurarão maximizar seus retornos, dificultando a acumulação de excedentes econômicos pela cooperativa (Bialoskorski Neto, 1998a).

Dessa forma, resta a alternativa de a cooperativa contrair empréstimos junto a terceiros, elevando seu nível de endividamento e as despesas com pagamento de juros.

Becho (1997), fundado na legislação brasileira, destaca que é vedado às cooperativas distribuírem qualquer espécie de benefício às quotas-partes do capital ou estabelecer outras vantagens ou privilégios, financeiros ou não, em favor de quaisquer associados ou terceiros, excetuando os juros até o máximo de $12 \%$ ao ano que incidirão sobre a parte integralizada.

Assim sendo, considerando que o capital dos associados recebe remuneração muito inferior à praticada no mercado e devido ao fato de parcela expressiva de tais recursos ser indivisivel, os sócios, além de terem poucos estímulos para capitalizar sua empresa, não se sentem donos das mesmas, fato que pode tornar frágil o relacionamento entre as partes envolvidas, gerando as condições para a apropriação do poder por um grupo de associados que se perpetua no comando da cooperativa, conforme diagnosticado em diversos trabalhos (Benetti, 1985; Duarte, 1997; Medeiros, 1995).

Com vistas a superar citadas deficiências, Lazzarini et al.(1999) propõem a adoção dos seguintes mecanismos como alternativa para a capitalização de cooperativas:

- abertura de empresa não-cooperativa;

- emissão de títulos;

- abertura de capital da cooperativa; 
- contratos de participação;

- cooperativas de nova geração;

- conversão para empresa de capital aberto.

As companhias e quaisquer outras sociedades, sob o mesmo controle ou não, podem constituir consórcio para executar determinado empreendimento. $O$ consórcio não tem personalidade jurídica $e$ as consorciadas somente se obrigam nas condições previstas no respectivo contrato, respondendo cada uma por suas obrigações, sem presunção de solidariedade.

A prerrogativa de emissão de títulos de capitalização pelas cooperativas carece de autorização legislativa e de um organismo que discipline e fiscalize o funcionamento do mercado de valores mobiliários, a exemplo do que ocorre com as companhias de capital aberto, que são monitorizadas pela Comissão de Valores Mobiliários (CVM). As cooperativas teriam de abrir ao público, na forma da lei, suas demonstrações financeiras e permitir o exame de suas contas por serviço de auditoria externa independente, conforme sugere Eschenburg (1986). Além disso, seus administradores deverão submeter-se à responsabilização civil e penal na hipótese de praticarem atos que prejudiquem os sócios da cooperativa ou terceiros credores ou clientes. Para tanto, faz-se necessária a tipificação dos crimes e as penalidades correspondentes por intermédio de processo legislativo. 


\section{METODOLOGIA}

Neste capítulo são discutidos os principais procedimentos metodológicos adotados no processo de levantamento e análise dos dados da pesquisa. Sem a pretensão de esgotar o assunto em seus aspectos teóricos, é exposta uma breve descrição dos instrumentais de análise estatística multivariada.

\subsection{Considerações preliminares sobre o escopo da pesquisa}

As informações existentes no Brasil sobre cooperativismo agropecuário são dispersas e pouco consistentes. Desde 1980, quando foi levantado o último censo do cooperativismo brasileiro, o País indispõe de estatísticas oficiais. Constitui rara exceção o estado do Paraná que, por meio do Sindicato e Organização das Cooperativas do Paraná (OCEPAR), vem publicando há mais de duas décadas registros sobre o cooperativismo daquela Unidade da Federação.

As informações prestadas pela Organização das Cooperativas Brasileiras (OCB), no Anuário do Cooperativismo Brasileiro, embora tenham âmbito nacional, possuem sérias limitações de ordem prática, pois referem-se apenas às organizações cooperativas a ela filiadas. Hoje, com a liberdade de associação, estima-se que $40 \%$ das cooperativas agropecuárias do Brasil não estão associadas ao Sistema OCB. Além disso, o banco de dados da OCB é capaz de gerar reduzida quantidade de informações. Basicamente, seu conteúdo restringe-se aos seguintes dados: número de cooperativas, 
localização, atividades desenvolvidas, número de associados e número de empregados.

Com vistas a proporcionar visão mais abrangente do cooperativismo agropecuário, a presente dissertação trata a matéria de forma essencialmente descritiva. Essa opção justifica-se em razão da escassez de trabalhos de pesquisa sobre o referido objeto de estudo nos últimos 20 anos que permitam identificar, a priori, os fatores determinantes de sua constituição. Os trabalhos científicos realizados, nesse período, abordam, com freqüência, estudos de caso sobre determinadas vertentes do cooperativismo agropecuário.

Salomon (1999) tipifica como pesquisas descritivas as que têm por objetivo definir melhor o problema, proporcionar as chamadas intuições de solução, descrever comportamentos de fenômenos, definir e classificar fatos e variáveis. Mattar (1993) afirma que as pesquisas descritivas são dirigidas para a solução de problemas ou avaliação de alternativas de cursos de ação e destaca a variante levantamento de campo, para os casos em que se procura obter dados representativos da população de interesse. Mesmo admitindo que o agrupamento das pesquisas em classes não deixa de conter certos elementos arbitrários, Boyd et al. (1987) reiteram a posição dos autores anteriormente citados.

\subsection{Fontes de dados utilizadas na pesquisa}

Com o propósito de apresentar um panorama da agricultura cooperativa, foram utilizados dados de tabulação especial do Censo Agropecuário de 1995-96, fornecidos pelo Instituto Brasileiro de Geografia e Estatística (IBGE). Referidos dados contêm informações censitárias sobre os estabelecimentos agropecuários filiados a cooperativas agregadas em nível nacional, macrorregional e por unidades da federação. Esses elementos serão 
necessários no processo de exame do nível de modernização tecnológica e de organização do cooperativismo.

Subsidiariamente, serão considerados os trabalhos de Lopes \& Lopes (1997) e Lopes et al. (1997). Citados estudos resultaram de pesquisa realizada junto a 90 cooperativas agropecuárias de todo o Brasil.

A terceira, e mais importante, fonte de dados consiste no levantamento de dados primários em cooperativas selecionadas, segundo critérios discutidos na seção seguinte.

\subsection{Seleção da amostra de cooperativas agropecuárias}

O universo de interesse do presente estudo é constituído pelas cooperativas agropecuárias localizadas no Nordeste brasileiro e no norte de Minas Gerais. Esta mesorregião integra a base territorial da ação de organismos públicos gestores de políticas de desenvolvimento regional. É o caso da Superintendência de Desenvolvimento do Nordeste (SUDENE) e do Banco do Nordeste do Brasil (BNB).

Inicialmente, pretendia-se selecionar a amostra a partir da relação contida no Anuário do Cooperativismo Brasileiro, edição de 1998, publicado pela Organização das Cooperativas Brasileiras (OCB), o qual relaciona 492 organizações cooperativas do ramo agropecuário situadas na região Nordeste e no norte mineiro, respectivamente.

Contudo, a referida fonte apresenta informações incompletas sobre as cooperativas para a única variável quantitativa disponível (número de associados). Notou-se, ainda, que parcela expressiva das cooperativas que constam do cadastro da OCB estão com indicação de endereço desatualizada, fato que impediu a realização de contatos. Tentou-se, ainda, obter os dados diretamente do cadastro da $O C B$, que contém outras duas variáveis (número de 
empregados e receita operacional). Porém, a direção da OCB negou o pedido, alegando que não dispunha de autorização para tornar públicas informações desagregadas sobre suas filiadas.

Diante de tais dificuldades, restou a alternativa de trabalhar com o cadastro do Banco do Nordeste do Brasil (BNB), que dispõe de variada gama de informações sobre 341 cooperativas agropecuárias, contingente esse que representa $69,3 \%$ do universo inicialmente definido para a pesquisa. O relatório fornecido pelo BNB contém os seguintes elementos: denominação da cooperativa, data de fundação, endereço completo, pessoas para contato, valor contratado e saldo devedor das operações de crédito realizadas.

Considerando que nem todas as cooperativas relacionadas possuiam demonstrações financeiras atualizadas disponíveis, capazes de revelar diretamente seu porte econômico, tomou-se como proxy do tamanho o endividamento dessas empresas no BNB. Esta conduta encontra justificativa na prática bancária de emprestar maiores somas de recursos para as cooperativas que detenham maior número de sócios, bem como maior patrimônio ou maior volume de negócios.

Assim sendo, construiu-se uma variável univariada por intermédio de escores reduzidos e centrados do saldo devedor de cada uma das cooperativas agropecuárias no BNB, conforme apresentado no Apêndice 1. Os pontos de corte para definição da medida preliminar de porte das cooperativas agropecuárias foram os seguintes:

- grande porte - 27 cooperativas situadas acima de um desvio padrão. Representam 7,9\% do universo considerado;

- médio porte - 84 cooperativas situadas entre a média e um desvio padrão. Este contigente corresponde a $24,6 \%$ do universo considerado; 
- pequeno porte - 123 cooperativas situadas até meio desvio padrão abaixo da média, correspondentes a $36,1 \%$ do universo considerado;

- microporte - 107 cooperativas situadas abaixo de menos meio desvio padrão, correspondentes a $31,4 \%$ do universo considerado.

A etapa seguinte do processo de amostragem seria a definição do tamanho da amostra. De acordo com Stevenson (1981), no caso de populações finitas, o tamanho amostral é aproximadamente igual a:

$n=\frac{0,25 z_{g}^{2} N}{B^{2} N+0,25 z_{g}^{2}}$

onde:

$n=$ Tamanho da amostra

$N=$ Tamanho da população

$z_{g}=$ Constante extraída da tabela de distribuição normal

$B=$ Erro máximo admissivel

Logo, o tamanho da amostra não estratificada poderia ser dimensionado, mediante a admissão de erro de estimação não superior a $B$, com nível de confiança de G. Na hipótese de opção por processo probabilístico, cada uma das cooperativas deveria ter a mesma chance de ser sorteada. No Quadro 1, apresentam-se seis alternativas de tamanho de amostra para uma população finita constituída de 341 elementos. 


\begin{tabular}{|c|c|c|}
\hline \multirow{2}{*}{$\begin{array}{c}\text { Coeficiente de } \\
\text { confiança (G) }\end{array}$} & \multicolumn{2}{|c|}{$\begin{array}{c}\text { Erro máximo admissivel } \\
\text { (B) }\end{array}$} \\
\cline { 2 - 3 } & 0,10 & 0,05 \\
\hline $95 \%$ & 75 & 181 \\
\hline $90 \%$ & 57 & 151 \\
\hline $80 \%$ & 36 & 110 \\
\hline
\end{tabular}

\section{Quadro 1. Definição do tamanho amostral.}

Fonte: elaboração do autor.

De acordo com as discussões iniciais, o propósito da pesquisa consiste em examinar múltiplos caracteres das cooperativas. Desta forma, seria mais recomendável trabalhar com amostragem probabilística estratificada. Porém, esta alternativa mostrou-se inviável, pois exigia o levantamento de amostra excessivamente grande, o que envolveria custos impeditivos.

Em face das razões antes narradas, adotou-se a conduta de trabalhar com amostragem por julgamento, na crença de que as eventuais perdas de rigor estatístico seriam compensadas pela representatividade derivada da experiência profissional do autor em seu relacionamento institucional com cooperativas agropecuárias do Nordeste. Assim sendo, atendidas as limitações de ordem financeira, o tamanho da amostra foi dimensionado em 41 cooperativas.

A sistemática de escolha das cooperativas integrantes da amostra obedeceu aos seguintes procedimentos, a partir da lista das 341 cooperativas constantes do Apêndice 1:

- deveriam ser visitadas cooperativas do maior número possível de estados da região Nordeste e do norte de Minas Gerais;

- a pesquisa deveria reunir informações de cooperativas dos segmentos de produção de soja, arroz, algodão, frutas e leite; 
- deveriam ser incluídas cooperativas fundadas até 1988 e cooperativas constituídas durante os anos noventa;

- deveriam ser escolhidas cooperativas de todos os portes, observada a distribuição de freqüência obtida a partir do saldo devedor da lista obtida do Banco do Nordeste.

As cooperativas selecionadas foram examinadas por intermédio da aplicação de questionário estruturado não disfarçado, constante do Apêndice 2, que reúne informações sobre os seguintes aspectos:

- recursos humanos das cooperativas;

- atividades econômicas das cooperativas;

- serviços prestados aos produtores rurais filiados;

- relações institucionais mantidas com outras organizações;

- políticas estratégicas e operacionais adotadas.

A aplicação do questionário foi realizada pelo autor, auxiliado por técnicos cedidos pelo Banco do Nordeste (BNB), mediante entrevista pessoal com os principais executivos das cooperativas relacionadas no Anexo 1. $\mathrm{Na}$ maioria dos casos, estiveram presentes à entrevista pelo menos um representante da diretoria (ou conselho de administração) acompanhado de prepostos da gerência operacional.

As visitas foram realizadas entre janeiro e maio de 1999, envolvendo cooperativas agropecuárias de oito estados, ficando fora da pesquisa apenas Alagoas e Sergipe.

- no estado do Ceará, a pesquisa foi realizada em 12 cooperativas. Esta concentração deveu-se ao fato de as cooperativas situarem-se 
em municípios próximos, condição que favoreceu a redução dos custos de levantamento dos dados. As cooperativas do Ceará foram dominantemente constituídas nos anos setenta e oitenta e exploram a produção de leite, algodão e arroz;

- na Paraiba, a pesquisa alcançou oito cooperativas. Referidas cooperativas trabalham com leite, algodão e frutas;

- no norte de Minas Gerais, em Pernambuco e no Rio Grande do Norte foram visitadas quatro cooperativas, respectivamente;

- no Piauí e na Bahia, respectivamente, foram visitadas três cooperativas que trabalham no setor de laticínio e na produção de frutas;

- as duas cooperativas do Maranhão atuam na produção de grãos, foram fundadas depois de 1993, sendo uma de grande porte e a outra de tamanho médio.

\subsection{Métodos estatísticos multivariados}

O cooperativismo agropecuário nordestino é afetado por múltiplas variáveis que se estendem desde a base produtiva ao elo mais avançado da área de atuação geoeconômica da cooperativa.

Assim sendo, para tornar evidente os traços determinantes da realidade, em estudos descritivos recomenda-se a utilização de técnicas estatísticas que considerem as várias dimensões do objeto de estudo, preservando o máximo possível de informações.

Tais métodos baseiam-se em conceitos de distâncias entre variáveis caracterizadoras de indivíduos, permitindo a identificação de fatores significativos de variáveis representadas em planos que tornam possível 
evidenciar como os indivíduos estão relacionados. A proximidade entre os indivíduos $e \quad O$ afastamento entre os grupos permitem que se criem classificações que poderão ser úteis, como primeira análise, à exploração do tema, ajudando na formulação de hipóteses, em estudos posteriores.

Portanto, a construção de uma tipologia, realizada com base no conjunto de características dos indivíduos, viabiliza distinguir as categorias de indivíduos e de variáveis. Logo, sua aplicação na avaliação de diferentes fenômenos que afetam o cooperativismo agropecuário nordestino facilita a proposição de ações específicas voltadas para segmentos homogêneos de organização, evitando a dispersão de recursos financeiros e institucionais.

Considerando a preponderância de variáveis qualitativas na descrição das aludidas cooperativas, avalia-se que a análise de correspondências múltiplas (ACM) e a análise de agrupamentos atendem às especificidades do presente estudo e serão utilizadas neste trabalho conjugadas, sempre que se fizer necessário, com a análise fatorial.

Nas subseções seguintes será apresentada uma breve resenha sobre as técnicas multivariadas aqui referidas.

\subsubsection{Análise de correspondências múltiplas}

A análise fatorial de correspondências múltiplas constitui uma técnica estatística multivariada que permite a comparação simultânea de todos os indivíduos (objetos) que compõem determinado estudo mediante a avaliação do grau de semelhança que guardam entre si, bem como a determinação do nível de associação entre as características (variáveis qualitativas) observadas.

No presente estudo, os indivíduos são cada uma das cooperativas pesquisadas e as variáveis são os atributos que as descrevem, tais como 
tamanho, nível de atividade econômica, desempenho financeiro, nível de endividamento etc.

A técnica aqui referida trabalha exclusivamente com atributos qualitativos, razão por que se faz necessária a uniformização da massa de dados. Adiante serão descritos os procedimentos adotados para a transformação das variáveis quantitativas em qualitativas, bem como das variáveis nominais em ordinais.

Uma variável é quantitativa quando assume valores discretos ou contínuos que denotam a grandeza extensiva do atributo. Já a variável qualitativa incorpora atributos que exprimem tão-somente relação de ordem, quando numéricos, e associação nominal nos demais casos.

Assim sendo, uma vez realizado o tratamento das variáveis, obtém-se a matriz de dados condensada, cujas linhas representam os individuos (cooperativas) e as colunas as variáveis, conforme disposição apresentada no Quadro 2.

\begin{tabular}{|c|c|c|c|c|c|c|}
\hline \multirow{2}{*}{ Indivíduo } & \multicolumn{7}{|c|}{ Variável } \\
\cline { 2 - 7 } & 1 & 2 & $(\ldots)$ & $\mathrm{J}$ & $(\ldots)$ & $\mathrm{J}$ \\
\hline 1 & $x_{11}$ & $x_{12}$ & $x_{1 .}$ & $x_{1 j}$ & $x_{1 .}$ & $x_{1 J}$ \\
\hline 2 & $x_{21}$ & $x_{22}$ & $x_{2 .}$ & $x_{2 j}$ & $x_{2 .}$ & $x_{2 J}$ \\
\hline$(\ldots)$ & $x_{.1}$ & $x_{2}$ & $x_{.}$ & $x_{. j}$ & $x_{. .}$ & $x_{. J}$ \\
\hline $\mathrm{I}$ & $x_{i 1}$ & $x_{i 2}$ & $x_{i .}$ & $x_{i j}$ & $x_{i .}$ & $x_{i J}$ \\
\hline$(\ldots)$ & $x_{. .}$ & $x_{. .}$ & $x_{. .}$ & $x_{. .}$ & $x_{. .}$ & $x_{. .}$ \\
\hline$I$ & $x_{11}$ & $x_{12}$ & $x_{l .}$ & $x_{I j}$ & $x_{l .}$ & $x_{I J}$ \\
\hline
\end{tabular}

Quadro 2. Matriz de dados condensada.

Fonte: Crivisqui (1993).

Nesta matriz, I é o número de indivíduo, $J$ o número de variáveis qualitativas e $x_{i j}$ é o código atribuído ao indivíduo $i$ para a variável $j$. 
Evidentemente, por se tratar de codificação que não apresenta propriedade numérica, esses dados não podem ser utilizados diretamente, necessitando de novo reordenamento.

Para tanto, tais dados podem ser representados por meio de uma matriz de dados disjuntiva completa em que as linhas representam os indivíduos e as colunas representam as modalidades das variáveis (Quadro 3). $\mathrm{Na}$ interseção da linha $i$ com a coluna $k$, encontra-se $x_{i k}$ que assume o valor 1 (um) ou 0 (zero), conforme o indivíduo enquadre-se ou não, respectivamente, em determinada modalidade de cada variável.

\begin{tabular}{|c|c|c|c|c|c|c|c|c|c|c|c|c|}
\hline \multirow{3}{*}{ Indivíduo } & \multirow{2}{*}{\multicolumn{3}{|c|}{$\begin{array}{l}\text { Variável } 1 \\
\text { Modalidade } \\
\end{array}$}} & $(\ldots)$ & \multirow{2}{*}{\multicolumn{3}{|c|}{$\begin{array}{c}\text { Variável j } \\
\text { Modalidade } \\
\end{array}$}} & $(\ldots)$ & \multirow{2}{*}{\multicolumn{3}{|c|}{$\begin{array}{c}\text { Variável } \mathrm{p} \\
\text { modalidade } \\
\end{array}$}} & \multirow{3}{*}{ Total } \\
\hline & & & & $(\ldots)$ & & & & $(\ldots)$ & & & & \\
\hline & 1 & $(\ldots)$ & $k_{1}$ & $(\ldots)$ & $\mathrm{k}_{\mathrm{i}-1}+1$ & $(\ldots)$ & $k_{i-1}+k_{i}$ & $(\ldots)$ & $\mathrm{k}_{\mathrm{p}-1}+1$ & $(\ldots)$ & $\mathrm{K}$ & \\
\hline 1 & 0 & $\ldots 0 \ldots$ & $\ldots 1 \ldots$ & $\ldots$ & 0 & $\ldots 1 \ldots$ & 0 & $\ldots$ & 1 & $\ldots 0 \ldots$ & 0 & $p$ \\
\hline 2 & 1 & ...0.. & $\ldots 0 \ldots$ & $\ldots$ & 1 & $\ldots 0 \ldots$ & 0 & $\ldots$ & 0 & $\ldots 0 \ldots$ & 1 & $p$ \\
\hline 3 & 0 & $\ldots 1 \ldots$ & $\ldots 0 \ldots$ & $\ldots$ & 0 & $\ldots 1 \ldots$ & 0 & $\ldots$ & 0 & $\ldots 1 \ldots$ & 0 & $\mathrm{p}$ \\
\hline . & - & - & • & . & - & - & - & - & • & . & • & - \\
\hline . & . & . & . & . & . & . & . & . & . & . & . & . \\
\hline I & 0 & $\ldots 1 \ldots$ & 0 & $\ldots$ & 1 & $\ldots 0 \ldots$ & 0 & $\ldots$ & 0 & $\ldots 0 \ldots$ & 1 & $p$ \\
\hline . & . & - & . & . & . & . & . & . & . & . & . & • \\
\hline . & . & . & . & . & . & . & . & . & . & • & . & $\cdot$ \\
\hline $\mathrm{N}$ & 1 & $\ldots 0 \ldots$ & 0 & $\ldots$ & 0 & $\ldots 1 \ldots$ & 0 & $\ldots$ & 0 & $\ldots 0 \ldots$ & 1 & $p$ \\
\hline Total & $n_{1}$ & $\ldots$ & $n_{k 1}$ & $(\ldots)$ & $n_{k j-1+1}$ & $\ldots$ & $n_{k j-1+k j}$ & $(\ldots)$ & $n_{k p-1+1}$ & $\ldots$ & $n_{k}$ & $\mathrm{np}$ \\
\hline
\end{tabular}

\section{Quadro 3. Matriz disjuntiva completa.}

Fonte: Crivisqui (1993).

Cumpre destacar que a matriz disjuntiva completa possui as seguintes propriedades:

- a soma das modalidades referentes a cada variável é sempre 1, para um mesmo indivíduo, visto que este deve enquadrar-se em apenas uma classe;

- a soma de cada linha é igual a $p$ (número de variáveis); 
- a última linha da matriz representa a freqüência total de cada modalidade em relação à massa total de dados;

- o total de modalidades é dado pela soma das modalidades de todas as variáveis, isto é, $K=\sum_{m=1}^{p} k_{m}$, em que $K$ é o número total de modalidades e $p$ é o número de variáveis;

- mantêm-se preservadas as informações contidas na matriz de dados condensada, com a vantagem de que nesta disposição a tabela lógica adquire propriedades numéricas.

\subsubsection{Análise de agrupamentos}

A análise de agrupamentos (cluster analysis) compreende uma série de técnicas e algoritmos empregados para separar objetos em classes que reúnam elementos os mais similares possíveis, devendo estas apresentar grande heterogeneidade entre si.

Definidas as variáveis que devem ser capazes de descrever e discriminar os objetos (indivíduos) do estudo, faz-se necessária a escolha de uma adequada medida de similaridade. Este instrumento avalia o quanto um indivíduo é parecido ou diferente dos demais componentes sem fazer nenhuma ilação a respeito de possíveis relações de casualidade.

Os métodos de classificação podem ser utilizados quando, logicamente, os elementos da tabela inicial de dados sejam classificáveis, o que quer dizer que, se os indivíduos estão dispostos no espaço, vão existir zonas de alta densidade de indivíduos e entre essas zonas haverá uma baixa densidade de indivíduos. 
As zonas de alta densidade serão produzidas pela semelhança entre os indivíduos. Esta semelhança pode ser avaliada por meio de índices de (dis)similaridade denominados de distâncias.

Os coeficientes de similaridade mais utilizados são os derivados da distância euclidiana entre dois pontos. Sharma (1996) inicia a discussão da técnica utilizando o quadrado da distância euclidiana, conforme expresso na relação 3:

$$
D_{i j}^{2}=\sum_{k=1}^{p}\left(x_{i k}-x_{j k}\right)^{2}
$$

em que $D_{i j}^{2}$ é o quadrado da distância entre o objeto $i$ e $j, x_{i k}$ é o valor da $k$ ésima variável para o l-ésimo indivíduo, e $x_{j k}$ é o valor da $k$-ésima variável para o j-ésimo indivíduo, e p é o número de variáveis.

A partir da medida antes indicada, constrói-se a matriz de similaridade (de dimensão $n \times n$ ) entre os indivíduos. Como o que se busca é a reunião em grupos de elementos semelhantes, deve-se inicialmente juntar os dois objetos que apresentem a menor distância entre si.

Após tal fusão, passa-se a ter $n$-1 observações, uma vez que o primeiro grupo formado é tratado como se fosse uma observação única. Em seguida, é reconstruída a matriz de similaridade (com dimensão $n-1 \times n-1$ ). A partir desta etapa, os métodos utilizados para calcular a distância entre os objetos apresentam diferentes procedimentos.

Quando o número de elementos não é muito grande, é possível construir uma série de partições encaixadas. Este método de classificação recebe o nome de classificação hierárquica e pode ser realizado de forma ascendente ou descendente. A classificação hierárquica ascendente consiste em considerar todos os elementos do conjunto total como classes constituídas, inicialmente, 
de um só elemento. Quando o número de indivíduos é demasiado grande, utilizam-se os métodos de classificação mistos, que permitem iniciar o procedimento com um número predeterminado de partições e finalizá-lo com uma classificação do tipo hierárquico (Kageyama \& Leone, 1999).

Segundo Bussab et al. (1990), as técnicas hierárquicas mais conhecidas e empregadas nos softwares estatísticos são as seguintes:

- método centróide - considera a média aritmética dos valores atribuídos aos objetos fusionados no grupo para fins de cálculo da matriz de similaridade;

- método vizinho mais próximo - a distância entre dois grupos, ou seja, a matriz de similaridade, é representada pela menor distância entre todos os possíveis pares de objeto. Em geral, se um grupo $k$ contém $n_{k}$ objetos e um outro grupo contém $n_{j}$ objetos, então a distância entre eles será a menor distância entre os $n_{k} \times n_{j}$ pares de distância;

- método vizinho mais distante - a distância entre dois grupo é representada pela maior distância entre todos os possíveis pares de objeto. Em geral, se um grupo $k$ contém $n_{k}$ objetos e um outro grupo contém $n_{j}$ objetos, então a distância entre eles será a maior distância entre os $n_{k} \times n_{j}$ pares de distância;

- método de encadeamento pela média - a distância entre dois grupos é feita tomando-se a média da distância de todos os possíveis pares de objeto;

- método de Ward - este método minimiza a soma do quadrado total em cada grupo. Uma particularidade deste método em relação aos 
anteriormente apresentados consiste no fato de que não se realiza o levantamento de distâncias entre grupos ou classes.

Na obtenção das partições iniciais, utiliza-se o critério de "agregação em torno dos centros móveis". Trata-se de um procedimento iterativo em que, a partir da escolha das partições aleatórias iniciais de centros de gravidade, aumenta-se a inércia entre as classes a cada iteração até obter grupos estáveis que serão a base para a etapa seguinte de classificação hierárquica. (Ver Figura 1).

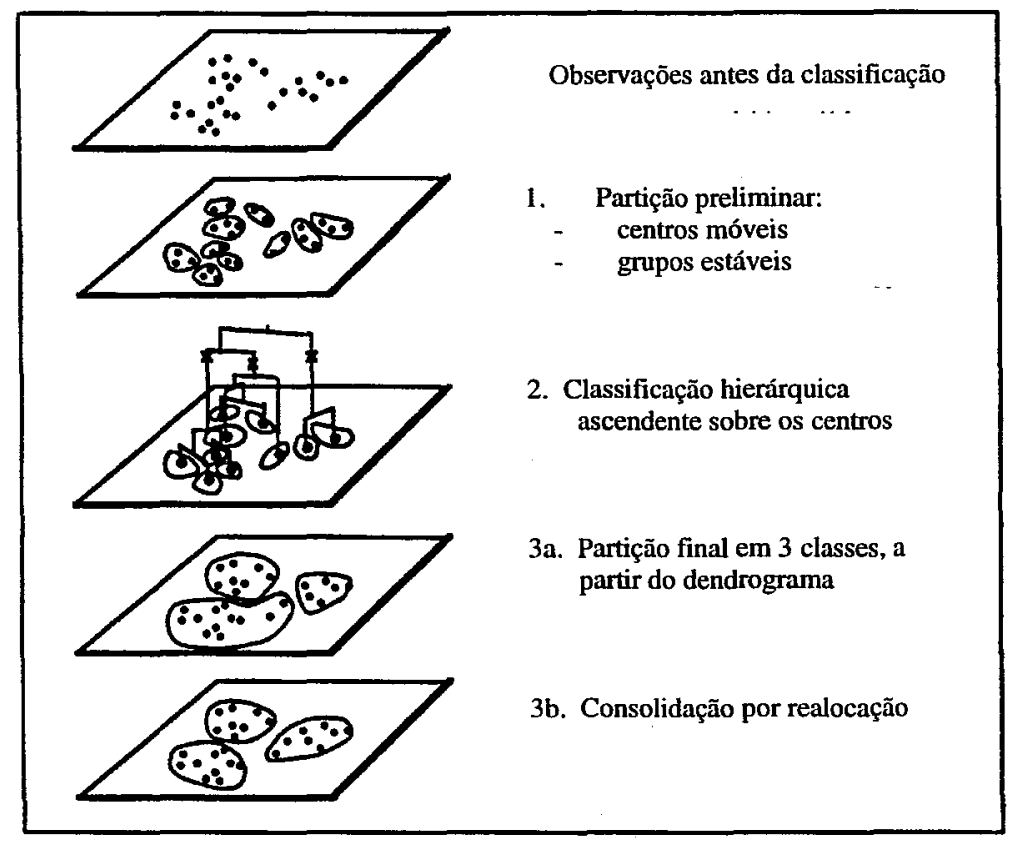

Figura 1. Esquema da classificação mista.

Fonte: Lebart et al. (1995).

A escolha de uma "boa partição", isto é, a definição do número de classes ou tipos para a análise geralmente é feita a partir do exame de um dendrograma em que se podem ler os índices de nível (ou índices de similaridade), que são as distâncias euclidianas em que ocorrem as junções dos indivíduos para formar os grupos. Um grande salto nesses índices (equivalente a uma grande distância num ramo do dendrograma) indica que a fusão se 
realizou reunindo dois grupos muito dissimilares e, por isto, deve-se reter o número de grupos anterior a esse salto.

De acordo com Kageyama \& Leone (1999), outros métodos mais precisos para a definição do número final de classes podem ser usados, mas o exame do dendrograma, ao lado do conhecimento prévio da possível estrutura "natural" de classes na população, quase sempre constituem uma boa solução.

\subsubsection{Análise fatorial pelo método de componentes principais}

Análise fatorial é um conjunto de técnicas estatísticas cuja finalidade é descrever as relações de um número elevado de elementos em termos de poucos fatores subjacentes e inobserváveis, agregando variáveis altamente correlacionadas e descrevendo-as como combinação de fatores laténtes (Hoffmann, 1994).

Assim sendo, os fatores são constituídos com apoio em alguns princípios básicos:

- as variáveis fortemente correlacionadas são combinadas em determinado fator;

- as variáveis que constituem determinado fator são praticamente independentes das variáveis que formam os outros fatores;

- os fatores são derivados de modo a maximizar a percentagem da variância total atribuída a cada fator consecutivo;

- os fatores são independentes entre si.

No presente trabalho utilizou-se a técnica de análise de componentes principais $(A C P)$ no estudo exploratório da estrutura da agricultura cooperativa, a partir de variáveis obtidas do Censo Agropecuário-1995-96 do IBGE representativas das unidades da federação brasileira. 
O referencial teórico de aludido método, descrito a seguir, reproduz, com pequenos ajustes julgados cabíveis, trabalho de revisão de literatura realizado por Kageyama \& Leone (1999), que se basearam nas obras de Lebart et al. (1995), Escofier \& Pagès (1992) e Crivisqui (1998).

$\mathrm{Na}$ aplicação desta técnica, considera-se uma tabela inicial de dados (ou matriz) de $n$ linhas que correspondem às unidades de observação e $k$ colunas que correspondem a variáveis, medidas em números reais, que expressam características específicas das unidades de observação ou indivíduos.

Os indivíduos podem ser considerados vetores cujas coordenadas são as observações das $k$ variáveis que se encontram dispostas nas linhas da tabela. Os pontos extremos das representações geométricas dos vetores são pontos situados no espaço $k$ dimensional, $\mathfrak{R}^{\mathbf{k}}$, em que cada dimensão representa uma variável.

De forma análoga, as $k$ variáveis podem ser representadas por vetores cujas coordenadas são as medidas relativas às características dos $n$ indivíduos e encontram-se dispostas nas colunas.

Cada variável pode ser representada por um vetor no espaço $n$ dimensional, $\mathfrak{\Re}^{n}$, onde cada dimensão representa um indivíduo. Isto significa que a mesma tabela pode ser analisada de duas maneiras diferentes: no espaço dos indivíduos e no espaço das variáveis (Figura 2). 


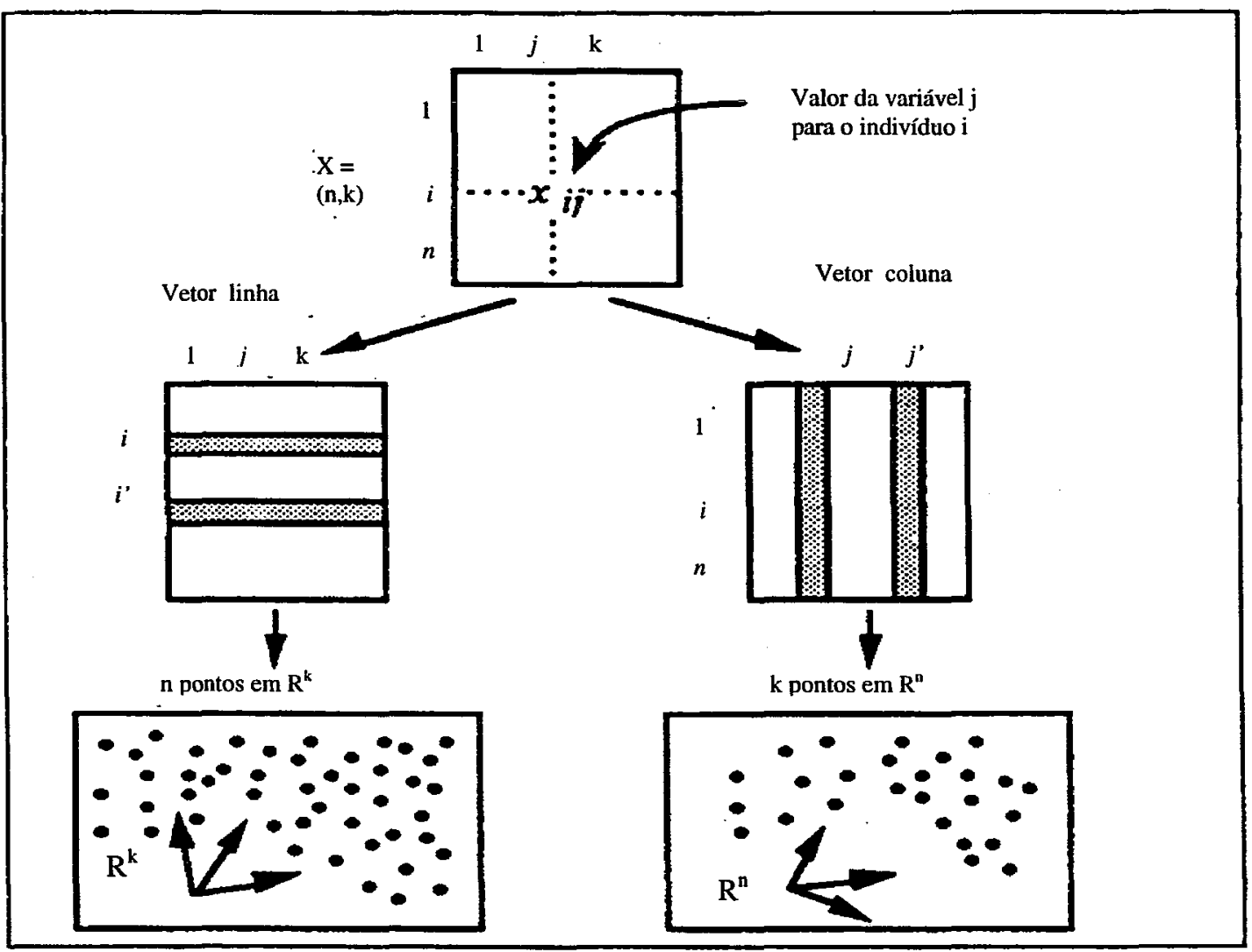

Figura 2. Representação geométrica dos indivíduos e variáveis.

Fonte: Lebart et al. (1995).

A ACP põe em evidência as proximidades entre os indivíduos e os vínculos entre as variáveis, permitindo sua visualização através de um resumo gráfico do conjunto de dados.

Para avaliar a semelhança entre dois indivíduos $i$ e $j$ utiliza-se o conceito de distância euclidiana ${ }^{6}$; quanto menor a distância, mais semelhantes são os indivíduos. A distância euclidiana é dada por:

$$
d^{2}(i, j)=\sum_{k=1}^{K}\left(x_{i k}-x_{j k}\right)^{2}
$$

${ }^{6}$ Para simplificar a exposição, supõe-se que a importância relativa dos indivíduos e das variáveis são as mesmas. 
A relação entre duas variáveis $k$ e $p$ é medida pelo coeficiente de correlação linear:

$$
r(k, p)=\frac{1}{n} \sum_{i=1}^{n}\left(\frac{x_{i k}-\bar{x}_{k}}{s_{x_{k}}}\right)\left(\frac{x_{i p}-\bar{x}_{p}}{s_{x_{p}}}\right)
$$

A finalidade da ACP é simplificar a representação da estrutura dos dados, procurando imagens planas que representem o "melhor possível" a disposição dos pontos-indivíduos no espaço $\mathfrak{R}^{\mathrm{k}}$ e a disposição dos pontosvariáveis no espaço $\Re^{n}$ sem precisar estabelecer nenhum modelo a priori. Isto quer dizer que a ACP busca novos referenciais para as duas nuvens de pontos, aquela constituída pelos indivíduos e aquela constituída pelas variáveis. Antes de proceder à aplicação da ACP, os dados da tabela inicial são centrados e reduzidos. $^{7}$

A centralização em $\mathfrak{R}^{k}$ eqüivale a uma translação dos eixos cartesianos da origem ao "centro de gravidade" da nuvem (ponto constituído pelos valores médios das variáveis). A redução, ao dividir os dados pelo desvio padrão, elimina o problema da dimensão da escala de medida das variáveis. Os conceitos estatísticos de média e variância recebem, por analogia com os fenômenos da física, os nomes de baricentro e inércia, respectivamente.

A forma da nuvem de pontos constituída pelos indivíduos no espaço $\mathfrak{R}^{k}$ é identificada pelas distâncias entre todos seus pontos. Para obter uma visualização mais simples da nuvem, procura-se um novo referencial constituindo um subespaço de menor dimensão, por exemplo, um plano no qual se projetam todos os pontos da nuvem de uma forma que procure minimizar as deformações envolvidas neste procedimento. Com esta finalidade, a soma dos

7 Realiza-se a seguinte transformação: $x_{i, j} \Rightarrow \frac{x_{i, j}-\bar{x} j}{s_{x_{j}}}$, e denota-se $X$ a matriz dos dados centrados e reduzidos. 
quadrados das distâncias entre os pontos da nuvem dos indivíduos (pontos localizados no $\Re^{k}$ ) e suas projeções (pontos projetados no subespaço gerado) deve ser mínima, o que, geometricamente, eqüivale a maximizar os quadrados das distâncias entre todos os pontos projetados nesse subespaço e o centro de gravidade da nuvem. Demonstra-se, também, que isto eqüivale a maximizar a soma dos quadrados das distâncias entre todos os pares de pontos projetados no subespaço. Em termos algébricos, a exposição retro adscrita corresponde, respectivamente, a:

$$
\begin{aligned}
& \min \frac{1}{n} \sum_{i=1}^{n} d^{2}\left(w_{i}, \hat{w}_{i}\right), \text { ou } \\
& \max \frac{1}{n} \sum_{i=1}^{n} d^{2}\left(\hat{w}_{i}\right), \text { ou } \\
& \max \sum_{i=1}^{n} \sum_{j=1}^{n} d^{2}\left(\hat{w}_{i}, \hat{w}_{j}\right)
\end{aligned}
$$

onde $\hat{w}_{i}$ e $\hat{w}_{j}$ são os pontos $w_{i}$ e $w_{j}$ projetados no subespaço (Ver Figura 3).

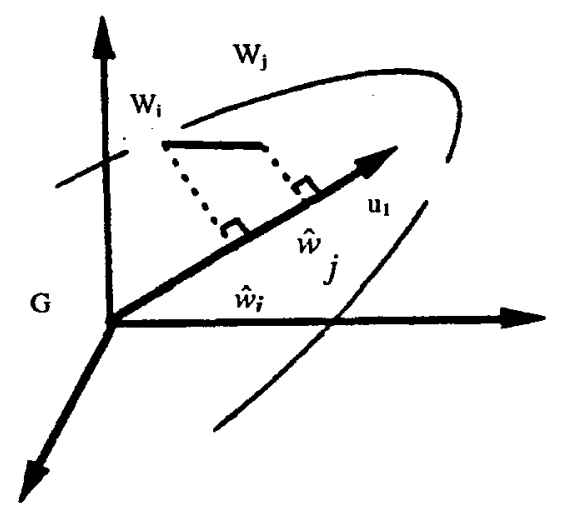

Figura 3. Projeção da distância entre dois indivíduos.

Fonte: Escofier \& Pagès (1992).

A ACP consiste, então, em procurar direções ou eixos privilegiados de $\Re^{k}$ que, passando pelo centro de gravidade da nuvem e tomados dois a dois, 
determinem planos sobre os quais se projetem os pontos da nuvem constituída pelos indivíduos de tal forma que cada direção torne máxima a inércia em relação ao centro de gravidade dos pontos projetados nessa direção.

Como se busca uma sucessão de direções, impõe-se a cada nova direção que seja ortogonal às encontradas anteriormente. Em termos matriçiais, denominando $u_{s}: s=1,2, \ldots, s$ as direções privilegiadas de $\mathfrak{R}^{k}$, busca-se, então, 0 vetor $\mathbf{u} \in \mathfrak{R}^{\mathrm{k}}$ que maximize $\boldsymbol{u}^{\prime} \boldsymbol{X}^{\prime} \boldsymbol{D} \boldsymbol{X} \boldsymbol{u}$, sujeito à restrição $\boldsymbol{u}^{\prime} \boldsymbol{u}=1$, recordando que $\boldsymbol{X}$ é a matriz de dados centrados e reduzidos, $\boldsymbol{D}$ é uma matriz de pesos cuja diagonal é igual a $1 / n$ e os outros elementos da matriz são zero e $X^{\prime} D X$ corresponde à matriz de correlações.

A solução do sistema consiste na diagonalização da matriz $V=X^{\prime} D X, 0$ que, em termos geométricos, eqüivale a obter os eixos de máxima inércia (que representam "melhor" a variabilidade dos pontos-indivíduos) e que resultam da obtenção dos autovetores $(\boldsymbol{u})$ e autovalores $(\lambda)$ associados à matriz $\boldsymbol{V}$ através da resolução do seguinte sistema de equações lineares:

$|\boldsymbol{V}-\lambda \boldsymbol{I}| \boldsymbol{u}=\boldsymbol{0}$, onde $\boldsymbol{I}$ é a matriz identidade.

Inicia-se o processo procurando a primeira direção principal $\boldsymbol{u}_{1}$ que satisfaça o critério acima; em seguida, busca-se $u_{2}$, ortogonal a $u_{1}$, que satisfaça o mesmo critério, e assim sucessivamente. $O$ vetor unitário $u_{1}$, que caracteriza o subespaço a uma dimensão e que melhor se ajusta à nuvem dos $n$ pontos constituídos pelos indivíduos em $\mathfrak{R}^{\mathrm{k}}$, é o autovetor da matriz $\boldsymbol{V}$ correspondente ao maior autovalor $\lambda_{1}$.

Em $\Re^{k}, u_{\alpha}$ corresponde à $\alpha$-ésima direção ou eixo e as coordenadas dos pontos-indivíduos, nesse eixo, são os componentes do vetor: $\boldsymbol{F}_{\boldsymbol{\alpha}}=\boldsymbol{X} \boldsymbol{u}_{\alpha}$.

Assim, os componentes principais $\boldsymbol{F}_{\boldsymbol{\alpha}}$ são combinações lineares das variáveis iniciais transformadas (centradas e reduzidas) e dispostas na matriz $\boldsymbol{X}$; 
os componentes principais são variáveis centradas, não correlacionadas e a variância do componente principal $\alpha$ é igual ao autovalor $\lambda_{\alpha}$.

$\mathrm{Na}$ tabela inicial de dados, as variáveis podem ser representadas como vetores no espaço $\Re^{n}$ e os pontos extremos do vetor constituem pontos nesse espaço cujas coordenadas são os valores centrados e reduzidos dispostos nas colunas da matriz $\boldsymbol{X}$. No espaço das variáveis, cada dimensão representa um indivíduo. Devido à centralização e redução dos dados, a norma (comprimento) de cada vetor é igual à unidade. Em termos geométricos isto quer dizer que os vetores encontram-se dentro de uma hiperesfera de raio 1 cujo centro é a origem dos eixos.

Analogamente ao caso dos indivíduos, procuram-se subespaços de menor dimensão que melhor representem as variáveis projetadas nesse subespaço. Neste caso, pode-se dizer que os planos procurados atravessam a hiperesfera (ver Figura 4).

Projeção de 4 variáveis

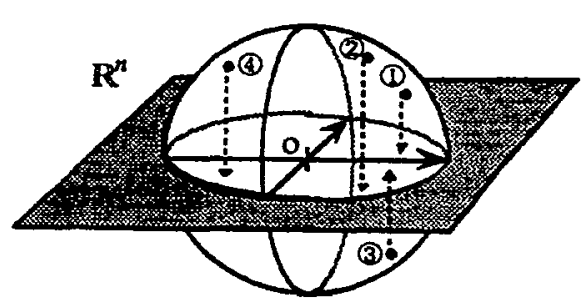

Círculo de correlações

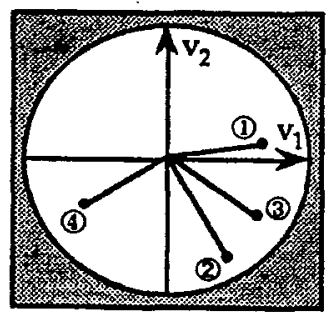

Figura 4. Representação da hiperesfera e do círculo de correlações. Fonte: Lebart et al. (1995).

A busca dos subespaços de menor dimensão no caso das variáveis obedece ao mesmo princípio utilizado no caso dos indivíduos. A interpretação, no entanto, é diferente. As direções privilegiadas no subespaço $\mathfrak{K}^{n}$ (novos eixos) são consideradas como variáveis sintéticas e as projeções das variáveis originais sobre essas variáveis sintéticas se analisam em termos de correlações 
que, geometricamente, correspondem aos co-senos dos ângulos entre as variáveis.

Assim, duas variáveis fortemente correlacionadas encontram-se muito próximas uma da outra e o co-seno estará próximo de 1; ao contrário, duas variáveis inversamente correlacionadas encontram-se afastadas uma da outra e o co-seno estará próximo de -1 . Duas variáveis que são ortogonais terão o coseno do ângulo entre elas igual a zero.

As direções principais $v_{s}: s=1,2, \ldots . . s$, no subespaço $\mathfrak{R}^{n}$, são obtidas através de fórmulas de transição entre os dois espaços. ${ }^{8}$ O vetor $\boldsymbol{v}_{\alpha}$ correspondente à $\alpha$-ésima direção é obtido da seguinte fórmula:

$$
v_{\alpha}=\frac{1}{\sqrt{\lambda_{\alpha}}} F_{\alpha}
$$

As coordenadas dos pontos-variáveis nesse eixo são os coeficientes de correlação entre as variáveis e os componentes principais e escreve-se:

$$
G_{\alpha}=\sum_{\alpha=1}^{k} \rho\left(x_{j}, F_{\alpha}\right) v_{\alpha}
$$

A qualidade de representação de uma variável no plano pode ser avaliada visualmente; como as variáveis são representadas por vetores, a qualidade de representação é dada pela proximidade dos extremos ao círculo de raio 1. A correlação entre duas variáveis é representada pelo ângulo que forma os vetores correspondentes.

Finalmente, cumpre destacar que é comum existirem indivíduos e/ou variáveis que por diferentes motivos (técnicos ou teóricos) não devem participar da construção dos eixos principais. Nestes casos, os indivíduos e variáveis

\footnotetext{
${ }^{8}$ Para uma demonstração da obtenção das fórmulas de transição, ver Lebart et al. (1995) e Escofier \& Pagès (1992).
} 
suplementares podem ser projetados sobre os primeiros planos de $\mathfrak{R}^{k}$ e $\Re^{n}$, respectivamente, mesmo sem terem afetado sua obtenção, mas podendo participar na sua interpretação e na análise dos resultados.

\subsection{Seleção das variáveis indicativas do grau de modernização da agricultura cooperativa}

Este segmento da dissertação introduz uma rápida discussão sobre as desigualdades regionais e funcionais na agricultura cooperativa, desenvolvida a partir da aplicação de método estatístico exploratório a um conjunto de variáveis indicativas de modernização, obtidas a partir de tabulação especial do Censo Agropecuário de 1995-96, do Instituto Brasileiro de Geografia e Estatística (IBGE).

A agricultura exerce importante papel no processo de desenvolvimento econômico dos países, fornecendo as condições necessárias para a industrialização. No Brasil, existe forte correlação entre crescimento da agricultura e crescimento dos demais setores, porque aquele não apenas apresenta grande participação no produto total, mas também por suas interligações intersetoriais, em especial com a indústria de produção de insumos agrícolas e agroindústrias de processamento de produtos primários (Souza, 1999).

Johnston \& Mellor (1961) enumeram cinco funções básicas da agricultura, a saber:

- fornecer alimentos e matérias-primas para o setor urbano-industrial;

- transferir poupanças para realização de inversões na indústria e para a implantação de infra-estrutura socioeconômica;

- liberar mão-de-obra para a indústria, evitando o crescimiento acelerado da massa de salários. Com isso, evita-se a depressão da 
taxa de lucros e assegura-se a acumulação contínua de capital. Esta função processa-se na fase inicial do crescimento econômico pois a produtividade marginal da força de trabalho na agricultura é praticamente nula $e$ os salários urbanos encontram-se institucionalmente acima do nível de subsistência;

- gerar divisas estrangeiras, por intermédio de exportações de produtos agrícolas, para financiar o desenvolvimento, adquirir bens importados e contribuir no custeio dos compromissos internacionais;

- constituir mercados para bens industriais, complementando os mercados urbanos.

O cumprimento de referidas funções favorece o aparecimento de dois fenômenos relacionados: agroindustrialização crescente e penetração do capitalismo no meio rural. No Brasil, esses processos ocorrem com intensidade diferente, dependendo da região geoeconômica e do produto agrícola explorado.

Souza (1999) chama a atenção para um terceiro fenômeno representado pela reversão da penetração do capitalismo no campo em estágio mais avançado do desenvolvimento econômico. O referido autor destaca o crescimento expressivo da presença de médias propriedades, na Europa e nos Estados Unidos, geridas por mão-de-obra familiar.

A exploração familiar corresponde a uma unidade de produção agrícola em que propriedade e trabalho estão intimamente ligados à família (Lamarche, 1993). É oportuno ainda destacar que agricultura familiar não se confunde com a agricultura tradicional de subsistência nem com a agricultura comercial. A essência do conceito de agricultura familiar reside no emprego predominante de mão-de-obra de membros da família, com uso eventual de trabalhadores contratados em determinadas épocas do ciclo produtivo. 
Bergamasco (1995) propõe que a agricultura familiar é constituída das seguintes categorias: trabalhadores por conta própria, parceiros por conta própria e membros não remunerados da família. Veiga (1995) adota uma dimensão mais restrita para delimitar a agricultura familiar no Brasil, considerando apenas as unidades de produção agropecuária que não empregam trabalhadores assalariados permanentes e que não recorrem a mais de cinco temporários em algum mês do ciclo produtivo. Os dois trabalhos retro citados convergem nos seguintes pontos: a agricultura familiar absorve mais de $60 \%$ da população ocupada na agropecuária, sendo mais representativa no Norte, Nordeste e Sul do Brasil.

A agricultura familiar matiza-se em diferentes estágios de desenvolvimento no que diz respeito ao grau de integração com o mercado. Há - grupo de unidades produtivas que faz uso intensivo de inovações tecnológicas e está integrado a agroindústrias capitalistas ou a cooperativas de produtores rurais. Em contraposição, encontram-se os produtores familiares que exploram culturas tradicionais, apresentam elevado nível de autoconsumo e incipiente relacionamento com os demais setores da economia. É nesse segmento da agricultura familiar que se observa, não raro, a ocorrência de produtividade marginal do trabalho próxima de zero e o emprego de técnicas de produção rudimentares (Kageyama \& Silveira, 1997).

O dualismo tecnológico retro aludido é explicado pelo modelo de Lewis, reproduzido analiticamente por Souza (1999), que se baseia na suposição de que o crescimento do setor urbano/industrial é capaz de induzir em longo prazo o desenvolvimento do setor agrícola.

De acordo com Souza (1999), o desenvolvimento dual compreende, portanto, um processo de articulação entre os setores moderno e atrasado, em que o crescimento do primeiro vai absorvendo o emprego redundante do segundo, propiciando o aumento gradual de sua produtividade. 
Contudo, a menor incidência de inovações por parte dos agricultores situados em regiões mais pobres, bem como a dificuldade de acesso a fontes de financiamento, notadamente dos pequenos produtores rurais, têm impedido a convergência da renda per capita - e de outras variáveis indicativas de desenvolvimiento econômico - entre regiões e atividades agrícolas (Kageyama \& Silveira, 1997).

Ademais, a tese de que a modernização da agricultura brasileira está associada a maiores níveis de renda, menor pobreza e maior desigualdade não é rejeitada por vários estudos realizados (Hoffmann \& Kageyama, 1985; Leone, 1988; Andrade, 1989; Hoffmann, 1990; Hoffmann, 1992; Corrêa, 1998).

Feitas essas considerações, cumpre assinalar que a modernização da agricultura é avaliada por meio da combinação de variáveis selecionadas. A escolha dos indicadores de modernização teve como ponto de partida os trabalhos de Leone (1988) e de Kageyama \& Silveira (1997).

Com os dados do Censo Agropecuário de 1995-96 foram construídas 14 variáveis indicadoras do grau de desenvolvimento da agricultura cooperativa, representativas de diferentes dimensões: padrão tecnológico, índices de produtividade, tipo de mão-de-obra utilizada, formas de organização administrativa e acesso a fontes de capitais de terceiros. As variáveis selecionadas foram as seguintes:

- VPES = Valor bruto da produção por estabelecimento agropecuário;

- $\mathrm{VPHA}=$ Valor bruto da produção agropecuária por hectare;

- $\quad$ VPPO = Valor bruto da produção por pessoal ocupado na agropecuária;

- $\mathrm{ATTO}=$ Percentual da área trabalhada em relação à área total dos estabelecimentos agropecuários; 
- CONT = Percentual de pessoas contratas (empregados, parceiros, outros) em relação ao total do pessoal ocupado na agropecuária;

- PERM = Percentual de empregados permanentes em relação ao total do pessoal ocupado na agropecuária;

- $\mathrm{FAML}=$ Percentual de membros da família em relação ao total do pessoal ocupado na agropecuária;

- TRAT = Percentual de estabelecimentos agropecuários que utilizam trator;

- ASTC = Percentual de estabelecimentos agropecuários beneficiados por serviços de assistência técnica;

- ENER = Percentual de estabelecimentos agropecuários que dispõem de energia elétrica;

- $F E R T=$ Percentual de estabelecimentos rurais que utilizam fertilizantes;

- $\mathrm{COOP}=$ Percentual de estabelecimentos agropecuários filiados a cooperativas;

- $\operatorname{ADMI}=$ Percentual de estabelecimentos agropecuários geridos por administrador contratado;

- FINA = Percentual de estabelecimentos agropecuários beneficiados por financiamento rural. 


\subsection{Seleção dos indicadores discriminantes das cooperativas agropecuárias da amostra}

Previamente à escolha dos indicadores descritivos das cooperativas que integram a amostra colhida, é importante que sejam feitas breves notas metodológicas sobre a coleta dos dados e apresentados os fundamentos conceituais envolvidos.

$\mathrm{Na}$ presente dissertação, trabalha-se uma análise cross-sectional que envolve a comparação de índices financeiros e socioeconômicos de diferentes cooperativas em um mesmo instante. Nesse sentido, a comparação de um índice específico com um índice padrão é feita com intenção de detectar desvios significativos em relação à norma.

Os dados da pesquisa de campo foram coletados entre 4 de janeiro e 7 de maio de 1999, tendo como data-base a situação da empresa em 31 de dezembro de 1999. Esta medida visou a reduzir os efeitos de sazonalidade inerentes à atividade agropecuária. Contudo, considerando que a amostra contém empresas cooperativas de diversos segmentos (soja, leite, arroz, algodão etc.), persistiram expressivas diferenças estruturais, dependendo do ramo de atividade explorado. As cooperativas de grãos invariavelmente apresentaram maior volume de produtos em estoque. As cooperativas que trabalham com algodão possuem maior grau de imobilização em ativos permanentes. As cooperativas do setor de laticínio apresentaram maior giro de ativo operacional em virtude dessa atividade possuir a caraterística de gerar rendas continuamente, embora o nível de produção decaia no período de estio.

Para contornar esse problema, é recomendável que se utilize em análises cross-section um conjunto de índices multivariados que "alise" os indicadores tradicionais (Gitman, 1997). Exemplo desse refinamento é considerar a rentabilidade da empresa cooperativa como ponderação das sobras líquidas em relação ao ativo total, ativo operacional, patrimônio líquido e 
receitas líquidas. Com isso, ficam reduzidos os efeitos dos estoques na data de levantamento das demonstrações financeiras na apuração dos indicadores de rentabilidade. Idêntico procedimento pode ser adotado em relação aos demais grupamentos de índices financeiros.

Os índices financeiros são subdivididos em quatro grupos ou categorias básicas: índices de liquidez, índices de atividade, índices de endividamento e índices de rentabilidade (Gitman, 1997; Greco \& Arend, 1998; Assaf Neto, 2000; Marion, 1998; Oliveira Júnior, 1986; ludícibus, 1980; Neves \& Viceconti, 1999).

O financiamento de empreendimentos corporativos pode ser feito de duas principais maneiras não excludentes. Na primeira delas, os sócios alocam seus capitais próprios para a realização de inversões coletivas. A outra forma é através da captação de capitais de terceiros, em geral, por intermédio de instituições financeiras. A situação mais comumente verificada é a composição de mix entre capitais próprios e capitais de terceiros que servem de fundos financiadores dos ativos econômicos. Em todo caso, a sociedade deve demonstrar capacidade econômica de gerar recursos suficientes para remuneração de seus investidores e credores financeiros.

Em geral, quanto mais dívida a empresa possui em relação ao capital total de seu ativo, portanto maior alavancagem financeira, maiores serão os riscos de insolvência. Assim sendo, os índices de endividamento visam a examinar a composição das fontes de recursos de empresa. O grau de endividamento de uma empresa determina sua dependência em relação a fontes externas para financiamento dos ativos (Assaf Neto, 2000).

Neves \& Viceconti (1999) ensinam que a alavancagem financeira representa a diferença entre a obtenção de recursos de terceiros a um determinado custo e a aplicação desses recursos no ativo da empresa a uma determinada taxa. É tal diferença (para mais ou para menos) que provoca alteração na taxa de retorno sobre o patrimônio líquido. Isto ocorre porque, de 
acordo com o direito empresarial que regula as sociedades comerciais $e$ as sociedades civis que possuam fins econômicos, os acionistas e/ou sócios apenas têm direitos residuais. Portanto, ao capital próprio cabe tão-somente os excedentes econômicos após pagamento da remuneração dos investidores externos à sociedade (bancos, fornecedores, debenturistas etc.), empregados e quitação de obrigações sociofiscais (Martins, 1999).

$O$ indicador de endividamento de uso mais freqüente é representado pela expressão 9 , em que no numerador estão reunidas as contas integrantes do passivo circulante e do passivo exigível de longo prazo, e no denominador, todas as contas do passivo, inclusive as representativas de capitais permanentes (dos sócios). Dessa forma, será possível comparar a estrutura de capitais das cooperativas da amostra com outras empresas do setor agropecuário.

$$
N E=\frac{E T}{P T}
$$

onde:

$N E=$ Nivel de endividamento total;

$E T=$ Exigivel (Passivo circulante + Passivo exigível de longo prazo);

$P T=$ Passivo total.

De acordo com o Balanço Anual da Gazeta Mercantil, em 1998, o nível de endividamento total das 55 maiores cooperativas agropecuárias do Brasil situou-se em 69,6\%. Portanto, tais empresas apresentam alto grau de alavancagem, sinalizando riscos consideráveis para os credores. Araújo (1996) faz alusão à ocorrência de índices de inadimplência (operações vencidas há mais de 60 dias e créditos em liquidação duvidosa) das cooperativas no Banco do Brasil de $23 \%$ em 1994. Bialoskorski Neto (1998), ao analisar duas séries cross-section de dados referentes ao ano-base de 1995 de cooperativas 
agropecuárias e de empresas não-cooperativas do setor de alimentos, constata que a taxa de crescimento da relação entre exigível de longo prazo e ativo imobilizado é maior no grupo das cooperativas. Este trabalho tem ainda o mérito de revelar que, a partir de determinado patamar de ativo imobilizado, a proporção de capitais de terceiros é maior nas empresas cooperativas.

Os índices de liquidez têm o objetivo de avaliar a capacidade de pagamento de uma organização, isto é, o cumprimento dos reembolsos das obrigações assumidas.

A liquidez corrente é a relação entre ativo circulante e passivo circulante, conforme expressão 10:

$$
L C=\frac{A C}{P C}
$$

onde:

$L C=$ Liquidez corrente;

$A C=$ Ativo circulante;

$P C=$ Passivo circulante.

A liquidez geral é a relação entre os ativos realizáveis e o passivo exigível, segundo a expressão 11:

$$
L G=\frac{A C+A R L P}{P C+P E L P}
$$

onde:

$L G=$ Liquidez geral;

$A R L P=$ Ativo realizável de longo prazo;

$P E L P=$ Passivo exigível de longo prazo. 
Um dos problemas ligados a estes indicadores consiste em seu caráter estático, que deixa de captar a magnitude e a distribuição temporal dos fluxos financeiros ativos e passivos. Por esta razão, é possível que uma empresa que apresente altos índices de liquidez passe por aperto financeiro em determinados momentos. Por isso, para fins gerenciais, é recomendável que se trabalhe com programação dinâmica de caixa.

Nenhum dos índices de liquidez aqui referidos apresentou poder discriminante significativo para ordenar as cooperativas constituintes da amostra, dada a forte homogeneidade delas nestes indicadores. Por esta razão, não figuram entre as variáveis selecionadas índices de liquidez.

Os índices de rentabilidade procuram comparar os resultados líquidos obtidos pela empresa em relação à universalidade de recursos utilizados nas operações econômicas. As expressões 12 a 17 apresentam diferentes modos de indicar a rentabilidade de organizações cooperativas:

$$
\begin{aligned}
& R S A=\frac{S L}{A T} \\
& R A O=\frac{S L}{A O} \\
& R P L=\frac{S L}{P L} \\
& M L=\frac{S L}{R L} \\
& F P A=\frac{R L}{N A T} \\
& F P E=\frac{R L}{N E M}
\end{aligned}
$$

onde: 
$R S A=$ Taxa de retorno sobre o ativo total;

$S L=$ Sobras líquidas após dedução de tributos;

$A T=$ Ativo total;

$A O=$ Ativo operacional (ativo total deduzidos os valores realizáveis referentes a operações de repasse a cooperado);

$R A O=$ Rentabilidade do ativo operacional;

$P L=$ Patrimônio líquido;

$R L=$ Receita líquida;

$M L=$ Margem líquida;

$N A T=$ Número de associados ativos;

$N E M=$ Número de empregados.

Por oportuno, cumpre destacar que nas organizações cooperativas, em geral, os índices de rentabilidade apresentam-se abaixo do desempenho das empresas não-cooperativas. Conforme divulgado no Balanço Anual da Gazeta Mercantil, em 1998, as 55 maiores cooperativas agropecuárias do Brasil tiveram prejuízos da ordem de $1,4 \%$ do patrimônio líquido.

A causa da baixa rentabilidade apresentada pelas cooperativas está diretamente associada à sua natureza organizacional. Por serem empresas que buscam a maximização da prestação de serviços, em geral, operam em nível de custo nas transações com associados (Becho, 1997).

Contudo, apesar de as cooperativas não visarem a lucro (no sentido de remuneração de capital), elas dependem essencialmente da obtenção de resultados econômicos para financiar seu desenvolvimento empresarial.

Assim sendo, observados os princípios cooperativistas, as sobras poderão ser destinadas ao aumento de capital, com o propósito de realizar investimentos comuns, ou distribuídas aos associados na proporção de suas 
operações com a cooperativa. Esta é a conduta defendida por diversos autores contemporâneos (Oliveira Júnior, 1986; Lima, 1997; Requejo, 1997; Bẹcho, 1997; Irion, 1997; Polonio, 1998; Panzutti, 1997).

Os índices de atividade são usados para medir a rapidez com que várias contas são convertidas em vendas ou em caixa (Gitman, 1997). Em geral, adota-se as seguintes medidas de atividade: giro de estoque, prazo médio de pagamento, período médio de cobrança, giro do ativo permanente e giro do ativo total. Para fins do presente trabalho, optou-se pelo último indicador, em virtude de sua maior abrangência.

O giro do ativo total, apresentado na expressão 18 , indica a eficiência com a qual a empresa usa todos os seus ativos para contribuir na geração de receitas. Geralmente, quanto maior for o índice, melhor será o aproveitamento dos recursos aplicados no ativo (Neves \& Viceconti, 1999).

$G A T=\frac{R L}{A T}$

onde:

GAT $=$ Giro do ativo total;

$R L=$ Receita líquida;

$A T=$ Ativo total

Feitas essas considerações, e com vistas a identificar possíveis diferenças existentes, foram selecionadas oito variáveis socioeconômicas representativas das múltiplas dimensões do processo de estruturação, organização e funcionamento das cooperativas pesquisadas.

\subsubsection{Variável 1 - Tamanho da cooperativa}

Antes de iniciar a proposta de estratificação, é importante assinalar que se pretende examinar as diferenças e similitudes internas do grupo de 
cooperativas estudado, não fazendo uso de parâmetros setoriais. Dessa forma, a classificação de uma cooperativa da amostra como de grande porte, por exemplo, não significa, necessariamente, que esse atributo guarde conformidade com o padrão nacional. É bastante que constitua boa aproximação da realidade nordestina. A propósito disto, é ilustrativo informar que o ativo médio das 55 maiores cooperativas agropecuárias do Brasil é da ordem de $\mathrm{R} \$ 32,9$ milhões e gera receita líquidas de $\mathrm{R} \$ 21,8$ milhões. Entre as cooperativas agropecuárias nordestinas que integram o presente estudo apenas duas (Cooperativa Agropecuária de Montes Claros e Cooperativa Agropecuária Batavo Nordeste) movimentam recursos econômicos dessa magnitude.

Para definir o modelo de tamanho com base multivariada procedeu-se à análise de correlação das variáveis: número de funcionários, número de associados, receita líquida, patrimônio líquido e ativo total.

Para tanto, utilizou-se a primeira componente principal da matriz de correlação como medida de tamanho multivariado. Esta componente representa $76,2 \%$ da dispersão total, podendo ser utilizada como medida geral de porte.

Caracterizada a componente principal, procedeu-se à análise univariada dos escores ordenados para determinar os pontos de corte para a medida de tamanho das cooperativas, conforme apresentado no Anexo 2. Foram definidos quatro tamanhos para fins de classificação das cooperativas:

- microporte (T1) - cooperativa situada além de meio desvio padrão abaixo da média;

- pequeno porte (T2) - cooperativa situada até meio desvio padrão abaixo da média; 
- médio porte (T3) - cooperativa situada acima da média até 2,5 desvios padrão;

- grande porte (T4) - cooperativa situada além de 2,5 desvios padrão acima da média.

\subsubsection{Variável 2 - Endividamento da cooperativa}

Conforme discutido anteriormente, esta variável representa a proporção de capitais de terceiros no conjunto dos recursos utilizados pelas cooperativas. Entre as grandes cooperativas agropecuárias nacionais, o endividamento total situa-se em torno de 70\% (Balanço anual da Gazeta Mercantil, 1998). Trabalho de pesquisa realizado por Lopes et al. (1997), que analisaram amostra de 90 cooperativas de todas as regiões do Brasil, indica que o endividamento total dessas organizações representa 104,0\% do patrimônio líquido.

Conforme apresentado no Anexo 3, a variável endividamento total foi segmentada em três modalidades:

- endividamento baixo (E1) - cooperativa cujo nível de endividamento é inferior a $70 \%$ do passivo total;

- endividamento moderado (E2) - cooperativa cujo nível de endividamento situa-se em $70 \%$ e $90 \%$ do passivo total;

- endividamento elevado (E3) - cooperativa cujo endividamento supera $90 \%$ do passivo total.

\subsubsection{Variável 3 - Giro do ativo da cooperativa}

O giro do ativo é um indicador que reflete a dinâmica dos negócios da cooperativa, visto que é dado pela relação entre receitas líquidas e o ativo total. 
Entre as grandes cooperativas nacionais, o giro do ativo situa-se em torno de $66 \%$ com expressivos desvios para mais e para menos.

Conforme apresentado no Anexo 4, foram estabelecidas três modalidades para esta variável:

- baixo giro operacional (N1) - cooperativas cujas receitas líquidas sejam inferiores a $10 \%$ do ativo total;

- moderado giro operacional (N2) - cooperativas cujas receitas líquidas situam-se entre $10 \%$ e $50 \%$ do ativo total;

- elevado giro operacional (N3) - cooperativas cujas receitas líquidas superam $50 \%$ do ativo total.

\subsubsection{Variável 4 - Desempenho econômico da cooperativa}

O ranking de desempenho econômico das cooperativas foi obtido a partir de fator que pondera as seguintes variáveis primárias: rentabilidade do ativo (RAT), rentabilidade do ativo operacional (RAO), rentabilidade do patrimônio líquido (RPL) e margem líquida (ML).

Previamente à construção do índice, foram apartadas oito cooperativas que se encontram em funcionamento precário, não realizando transações econômicas de expressão. São organizações que foram constituídas com o objetivo exclusivo de realizar operações de repasse, pouco atuando na atividade de comercialização. Estas cooperativas foram enquadradas de imediato na modalidade desempenho econômico precário (D1).

Com relação às 32 cooperativas restantes, extraiu-se a primeira componente principal que capta $84,2 \%$ da dispersão total como medida de desempenho econômico. Então, ordenados os escores, conforme apresentado no Anexo 5, foram definidas as seguintes modalidades: 
- desempenho econômico precário (D1) - cooperativa que possui desempenho econômico precário;

- desempenho econômico regular (D2) - cooperativa situada abaixo da média;

- desempenho econômico satisfatório (D3) - cooperativa situada acima da média.

\subsubsection{Variável 5 - Fundação da cooperativa}

Com esta variável espera-se captar a existência ou não de diferenças na performance empresarial das cooperativas criadas em período mais recente relativamente às mais antigas, constituídas no curso de ambiente institucional em que a economia brasileira era mais fechada ao comércio internacional e havia disponibilidade de incentivos à produção agropecuária. Dessa forma, procurou-se separar as cooperativas em dois grupos, adotando como marco divisor 5.10.1988. Esta é a data da promulgação da vigente Constituição da República, que introduz profundas modificações na política nacional de cooperativismo.

Portanto, conforme apresentado no Anexo 6, a variável em questão foi segmentada em duas modalidades:

- $\quad$ antiga (F1) - cooperativa constituída até 4.10.1988;

- $\quad$ nova (F2) - cooperativa constituída a partir de 5.10.1989.

\subsubsection{Variável 6 - Grau de relacionamento institucional}

Esta variável foi construída mediante o ordenamento dos escores médios obtidos a partir de dados sobre o grau de utilização, por cooperativas, de serviços prestados por organizações selecionadas. Para tanto, foi utilizada a 
escala de Likert com cinco pontos, em que se pediu para a cooperativa indicar com que freqüência faz uso de serviços de bancos, universidades, consultorias, instituições de pesquisa agrícola e outras organizações.

Conforme apresentado no Anexo 7, referida variável segmenta-se em duas modalidades, a saber:

- incipiente relacionamento institucional (I1) - cooperativa situada abaixo da mediana;

- satisfatório relacionamento institucional (12) - cooperativa situada acima da mediana.

\subsubsection{Variável 7 - Intensidade de uso de práticas administrativas}

Para construção desta variável foi apresentada uma lista contendo 16 ações administrativas e perguntado quais delas a cooperativa adotou ou vem adotando nos últimos três anos. Então, as 40 cooperativas são ordenadas de acordo com o número de respostas positivas.

Conforme disposto no Anexo 8 , esta variável foi segmentada em duas modalidades:

- utilização restrita de práticas administrativas (R1) - cooperativa situada abaixo da mediana;

- utilização intensiva de práticas administrativas (R2) - cooperativa situada acima da mediana.

\subsubsection{Variável 8 - Grau de escolaridade dos dirigentes}

Os modelos neoclássicos de crescimento econômico, desenvolvidos por Meade e Solow, concluem que o ritmo do progresso técnico determina o crescimento da renda per capita no equilíbrio de longo prazo (Souza, 1999). Por 
sua vez, as diversas teorias do crescimento endógeno procuram encontrar as fontes desse crescimento no interior do próprio sistema produtivo.

Souza (1999) relata diversos estudos teóricos e empíricos corroboram a tese de que investimentos em capacitação tecnológica e no capital humano possuem importância significativa no crescimento econômico: Investimentos em capital humano, de Schultz (1961); Implicações econômicas do aprender fazendo, de Arrow (1962); Investimento humano, difusão tecnológica e crescimento econômico, de Nelson e Phelps.

Langoni (1976), citado por Souza (1999), estudando outras fontes de crescimento, além de capital e trabalho, mostrou que a contribuição líquida da educação para o crescimento do produto foi de 15,7\% no Brasil entre 1960 e 1973), 23\% nos Estados Unidos entre 1950 e 1962 e de 10\% na França entre 1950 e 1962.

Freitas et al. (1998), mediante a utilização de técnicas de análise fatorial e de confiabilidade para mensurar os conceitos e dimensões do modelo estruturaconduta-desempenho (ECD), em um estudo sobre as empresas da construção civil em São Paulo, constataram a existência de correlação significativa $(0 ; 816)$ entre treinamento de pessoal e produtividade daquela indústria.

Isto posto, considerando que o produto de um país ou região é formado pela agregação da contribuição de cada agente econômico, espera-se que o desempenho individual da organização seja influenciado pelo nível de escolaridade de seus dirigentes.

$\mathrm{Na}$ construção desta variável foram atribuídos os pesos 1,3 e 6, respectivamente, segundo os níveis de escolaridade fundamental, médio e superior, para fins de obtenção de índice que expresse em escala univariada o perfil cognitivo dos dirigentes. Ordenados os escores, conforme apresentados no Anexo 9, foram estabelecidas as seguintes modalidades: 
- grau de escolaridade baixo (Z1) - cooperativa em que haja predomínio de dirigentes com formação escolar até 0 nível fundamental;

- grau de escolaridade médio (Z2) - cooperativa em que haja predomínio de dirigentes com formação escolar de nível médio;

- grau de escolaridade alta (Z3) - cooperativa em que haja predomínio de dirigentes com formação escolar de nível superior. 


\section{CARACTERIZAÇÃO DA AGRICULTURA COOPERATIVA}

\subsection{Introdução}

Neste capítulo é apresentada uma breve descrição da agropecuária cooperativa, procurando demonstrar que a base produtiva do agricultor filiado constitui, possivelmente, fator limitante de maior relevo ao desenvolvimento do cooperativismo no Nordeste.

Para tanto, realiza-se uma incursão exploratória sobre as profundas desigualdades regionais do desenvolvimento da agricultura cooperativa brasileira quanto às vertentes de modernização tecnológica e organizacional, níveis de produtividade obtidos e tipo da força de trabalho utilizada.

No estudo, foram empregados os instrumentais de análise fatorial pelo método de componentes principais e de análise de agrupamentos, como forma de situar o Nordeste brasileiro em relação ao restante do País a partir de um conjunto de variáveis obtidas de tabulação especial do Censo Agropecuário de 1995-1996 do IBGE.

A referida tabulação foi formatada, mediante encomenda ao IBGE que procedeu à segregação dos microdados referentes aos estabelecimentos agropecuários cujos produtores rurais declararam-se filiados à cooperativa.

Na parte final do texto é apresentado o perfil da agricultura cooperativa nordestina sob diversos aspectos: estrutura fundiária, condição do produtor, pessoal ocupado e principais atividades exploradas. 


\subsection{Características regionais da agricultura cooperativa no Brasil}

As características regionais da agricultura cooperativa brasileira podem ser descritas por intermédio de indicadores de modernização e organização visto que em diferentes espaços geoeconômicos é possível que sejam utilizadas diferentes proporções de fatores produtivos, maior ou menor grau do emprego força de trabalho assalariada ou familiar, bem como determinadas técnicas de organização e gestão administrativa.

Desse modo, tomando por base as variáveis definidas no capítulo 3 , seção 5 , foram apurados os indicadores correspondentes às 27 Unidades da Federação brasileira, apresentados no Anexo 10.

A aplicação do método às catorze variáveis e às 27 Unidades da Federação revelou ser suficiente trabalhar com três componentes que, conjuntamente, explicam alta proporção da variância total dos dados. Além desse, adotou-se como critério para definição do número de componentes a seleção dos autovalores maiores que a unidade.

O quadro 4 apresenta os maiores autovalores associados à matriz de correlação das variáveis, em ordem decrescente, e os respectivos percentuais de variância (simples e acumulado) explicados. Os resultados mostram que os três primeiros componentes principais explicam $81,84 \%$ da variabilidade total da nuvem de pontos. Portanto, mediante a utilização apenas de três fatores (ou três novas variáveis artificiais), pode-se interpretar o objeto de estudo de forma mais simples, comparativamente à análise das catorze variáveis originais, com perda somente de $18,16 \%$ da variabilidade total. 


\begin{tabular}{|c|c|c|c|c|}
\hline $\begin{array}{c}\text { Eixo } \\
\text { fatorial }\end{array}$ & Autovalor & $\begin{array}{c}\text { Autovalor } \\
\text { Acumulado }\end{array}$ & $\begin{array}{c}\text { Inércia } \\
\text { explicada } \\
(\%)\end{array}$ & $\begin{array}{c}\text { Inércia } \\
\text { acumulada } \\
(\%)\end{array}$ \\
\hline 1 & 7,745 & 7,745 & 55,32 & 55,31 \\
\hline 2 & 2,684 & 10,429 & 19,17 & 74,49 \\
\hline 3 & 1,029 & 11,458 & 7,35 & 81,84 \\
\hline
\end{tabular}

Quadro 4. Valores e variância explicada pelos três primeiros autovalores.

Fonte: dados da pesquisa.

O primeiro eixo fatorial tem o mesmo sinal para todas as coordenadas das variáveis significativas porque elas são positivamente correlacionadas com esta direção, conforme indicado na primeira coluna do Quadro 5. Entre as catorze variáveis escolhidas, apenas duas apresentam correlação negativa com esse eixo: FAML (percentual de membros da família em relação ao total do pessoal ocupado na agropecuária) e ADMI (percentual de estabelecimentos agropecuários geridos por administrador contratado), as quais apresentam baixa contribuição para a formação do eixo. 


\begin{tabular}{|c|c|c|c|}
\hline Variável & Fator 1 & Fator 2 & Fator 3 \\
\hline VPES & 0,343 & $\mathbf{0 , 8 5 3}$ & 0,248 \\
\hline CONT & 0,216 & $\mathbf{0 , 8 5 1}$ & $-0,402$ \\
\hline TRAT & 0,544 & 0,658 & 0,429 \\
\hline ASTEC & $\mathbf{0 , 7 3 1}$ & 0,367 & 0,434 \\
\hline PERM & 0,289 & $\mathbf{0 , 9 1 7}$ & $-0,112$ \\
\hline VPHA & $\mathbf{0 , 7 9 4}$ & 0,086 & 0,056 \\
\hline VPPO & 0,400 & $\mathbf{0 , 7 3 6}$ & 0,386 \\
\hline ADMI & $-0,120$ & $\mathbf{0 , 7 5 2}$ & 0,085 \\
\hline FINA & 0,277 & $-0,095$ & $\mathbf{0 , 7 7 7}$ \\
\hline ATTO & 0,578 & 0,607 & 0,142 \\
\hline COOP & $\mathbf{0 , 8 2 6}$ & 0,038 & 0,280 \\
\hline FAML & $-0,216$ & $-0,851$ & 0,402 \\
\hline ENER & $\mathbf{0 , 8 5 1}$ & 0,314 & $-0,022$ \\
\hline FERT & $\mathbf{0 , 9 1 5}$ & 0,219 & 0,106 \\
\hline Variância explicada & 7,745 & 2,684 & 1,029 \\
\hline Proporção da variância & 0,553 & 0,192 & 0,074 \\
\hline explicada & & & \\
\hline
\end{tabular}

\section{Quadro 5. Coordenadas - correlações - das variáveis nos três primeiros eixos fatoriais.}

Fonte: dados da pesquisa.

O primeiro eixo fatorial é correlacionado fortemente com as variáveis FERT (percentual de estabelecimentos agropecuários que utilizam fertilizantes), ENER (percentual de estabelecimentos agropecuários que dispõem de energia elétrica), ASTC (percentual de estabelecimentos agropecuários beneficiados por senviços de orientação técnica), COOP (percentual de estabelecimentos agropecuários filiados a cooperativas) e VPHA (valor bruto da produção agropecuária por hectare). Esse eixo sozinho consegue explicar $55,32 \%$ da inércia total, representando, basicamente, a dimensão tecnológica e organizacional do processo de produção, pois está fortemente associado com variáveis que captam medidas da adoção do pacote tecnológico do processo de modemização, nível de adesão ao cooperativismo e produtividade da terra. 
As Unidades da Federação com altos valores positivos para o primeiro componente principal, como Santa Catarina, Rio Grande do Sul, Paraná, São Paulo e Espírito Santo, apresentam agricultura de maior nível tecnológico, elevado nível de filiação ao cooperativismo e alta produtividade por hectare, indicando que as unidades de produção utilizam mais intensivamente o fator terra. Esse resultado decorre do fato de existir forte correlação positiva entre a variável COOP e as variáveis ASTC, ENER, FERT, respectivamente, 0,74, 0,76 e 0,72 .

Por outro lado, Unidades da Federação com altos valores negativos para o primeiro componente principal, tais como as da região Norte do País e o estado do Piauí, apresentam baixo nível tecnológico, incipiente índice de filiação ao cooperativismo e baixa produtividade do fator terra.

Relativamente ao primeiro eixo, os estados da região Nordeste ocupam, em média, posição intermediária. Os estados de Sergipe, com coordenada 0,5152 , e Pernambuco, com coordenada 0,2012, situam-se levemente acima da média nacional. Alagoas, com coordenada 0,0167, encontra-se rente à média do País. Os demais estados do Nordeste situam-se abaixo da média, ficando o Piauí e a Bahia na retaguarda.

O segundo eixo fatorial está positivamente correlacionado com as variáveis VPES (valor da produção por estabelecimento agropecuário), CONT (percentual de pessoas contratadas em relação ao total do pessoal ocupado na agropecuária), PERM (percentual de empregados permanentes em relação ao total de pessoal ocupado na agropecuária), VPPO (valor da produção por pessoal ocupado na agropecuária) e ADMI (percentual de estabelecimentos agropecuários geridos por administrador contratado) e correlacionado negativamente com a variável FAML (percentual de membros da família em relação ao total do pessoal ocupado na agropecuária). 
Esses resultados podem ser condensados em três vertentes: a primeira é indicativa de ganhos de produtividade do trabalho (VPPO) e de produtividade total (VPES); a segunda, denotativa da modalidade de mão-de-obra utilizada na produção, opõe a agricultura comercial, que opera com trabalhadores assalariados, e a agricultura familiar; por último, o segundo componente principal associa-se com a proxy que capta o modelo de gestão do empreendimento.

Assim sendo, as Unidades da Federação com elevados valores positivos para o segundo componente principal, como Mato Grosso do Sul, Distrito Federal e São Paulo, apresentam alta produtividade total e alta produtividade do trabalho, empregam predominantemente mão-de-obra assalariada e possuem maior proporção de estabelecimentos agropecuários administrados por profissionais contratados.

A análise do pólo negativo do segundo eixo requer o resgate dos resultados anteriores, pois seria impróprio afirmar que os estados do Rio Grande do Sul e de Santa Catarina, por estarem situados em elevada coordenada negativa, possuem agricultura subdesenvolvida. Considerando que os estados sulinos apresentaram elevadas coordenadas para o primeiro eixo, é razoável inferir que sua agricultura adota tecnologias modernas e possui alta produtividade da terra. Esta última evidência está associada ao fato de nessa região as propriedades serem, em média, menores que as do restante do País. Dessa forma, a posição ocupada por Santa Catarina e pelo Rio Grande do Sul, respectivamente, deve-se ao fato de empregarem predominantemente mão-deobra familiar e serem as unidade produtivas geridas pelos próprios produtores.

No Nordeste, destacam-se Alagoas e Bahia que possuem, no segundo eixo, coordenada positiva próxima de um desvio padrão. Com isso, esses estados colocam-se entre os que possuem agricultura comercial, detendo razoável nível de produtividade total e do trabalho. Em que pesem tais 
resultados, o estado da Bahia, em particular, apresenta baixa produtividade da terra, possivelmente em razão da grande extensão territorial de seus estabelecimentos agropecuários.

O terceiro eixo fatorial, ortogonal aos dois anteriores, que capta 7,35\% da variabilidade total, é positivamente correlacionado com a variável FINA (percentual de estabelecimentos agropecuários beneficiados por financiamento rural). Dado que esse eixo é constituído quase exclusivamente por única variável original, elevadas coordenadas positivas indicam maior acesso a mecanismos de financiamento. É o caso dos três estados do Sul do País, do Mato Grosso do Sul, Mato Grosso, Distrito Federal e, surpreendentemente, de dois estados do Norte do País: Pará e Roraima, todos com coordenada positiva superior a um desvio padrão. No outro extremo, estão os estados que recebem menor assistência creditícia: Alagoas, Pernambuco e Rio de Janeiro, os quais possuem coordenadas negativas superiores a um desvio padrão.

No Quadro 6 são apresentadas as comunalidades para os três eixos fatoriais e $\circ \operatorname{Cos}^{2}$. A comunalidade indica o quanto da variância de cada variável é captada pelos fatores. Por sua vez, o $\mathrm{Cos}^{2}$ indica a qualidade da representação de cada variável no espaço tridimensional. Portanto, nota-se, que todas as variáveis estão satisfatoriamente representadas no conjunto dos fatores extraídos. 


\begin{tabular}{|c|c|c|c|c|}
\hline Variável & Fator 1 & Fator 2 & Fator 3 & Cos $^{2}$ \\
\hline VPES & 0,789 & 0,841 & 0,908 & 0,976 \\
\hline CONT & 0,481 & 0,879 & 0,932 & 1,000 \\
\hline TRAT & 0,832 & 0,843 & 0,914 & 0,948 \\
\hline ASTC & 0,685 & 0,846 & 0,858 & 0,897 \\
\hline PERM & 0,703 & 0,937 & 0,937 & 0,963 \\
\hline VPHA & 0,365 & 0,545 & 0,641 & 0,870 \\
\hline VPPO & 0,747 & 0,750 & 0,851 & 0,971 \\
\hline ADMI & 0,228 & 0,488 & 0,588 & 0,550 \\
\hline FINA & 0,060 & 0,440 & 0,690 & 0,633 \\
\hline ATTO & 0,723 & 0,723 & 0,723 & 0,830 \\
\hline COOP & 0,395 & 0,741 & 0,763 & 0,832 \\
\hline FAML & 0,481 & 0,879 & 0,933 & 1,000 \\
\hline ENER & 0,632 & 0,705 & 0,824 & 0,883 \\
\hline FERT & 0,624 & 0,811 & 0,896 & 0,922 \\
\hline
\end{tabular}

Quadro 6. Comunalidades e contribuição total para a formação dos três eixos fatoriais.

Fonte: dados da pesquisa.

$\mathrm{Na}$ Figura 5, é apresentada a representação das Unidades da Federação no plano fatorial formado pelos dois primeiros eixos. A opção de apresentar apenas as duas primeiras dimensões tem 0 intuito de evitar sobrecarregar o gráfico, tendo em vista também a menor importância do terceiro eixo. Deve-se lembrar, contudo, que no plano apresentado é visto tãosomente a projeção dos pontos reais contidos no hiperplano. Assim sendo, convém assinalar que, embora visualmente duas projeções pareçam estar muito próximas no plano bidimensional, como é o caso dos pontos representativos dos estados Ceará e do Amapá, respectivamente, de fato estão bastantes distantes, por terem coordenadas do terceiro eixo consideravelmente afastadas, conforme se observa no Anexo 11. 


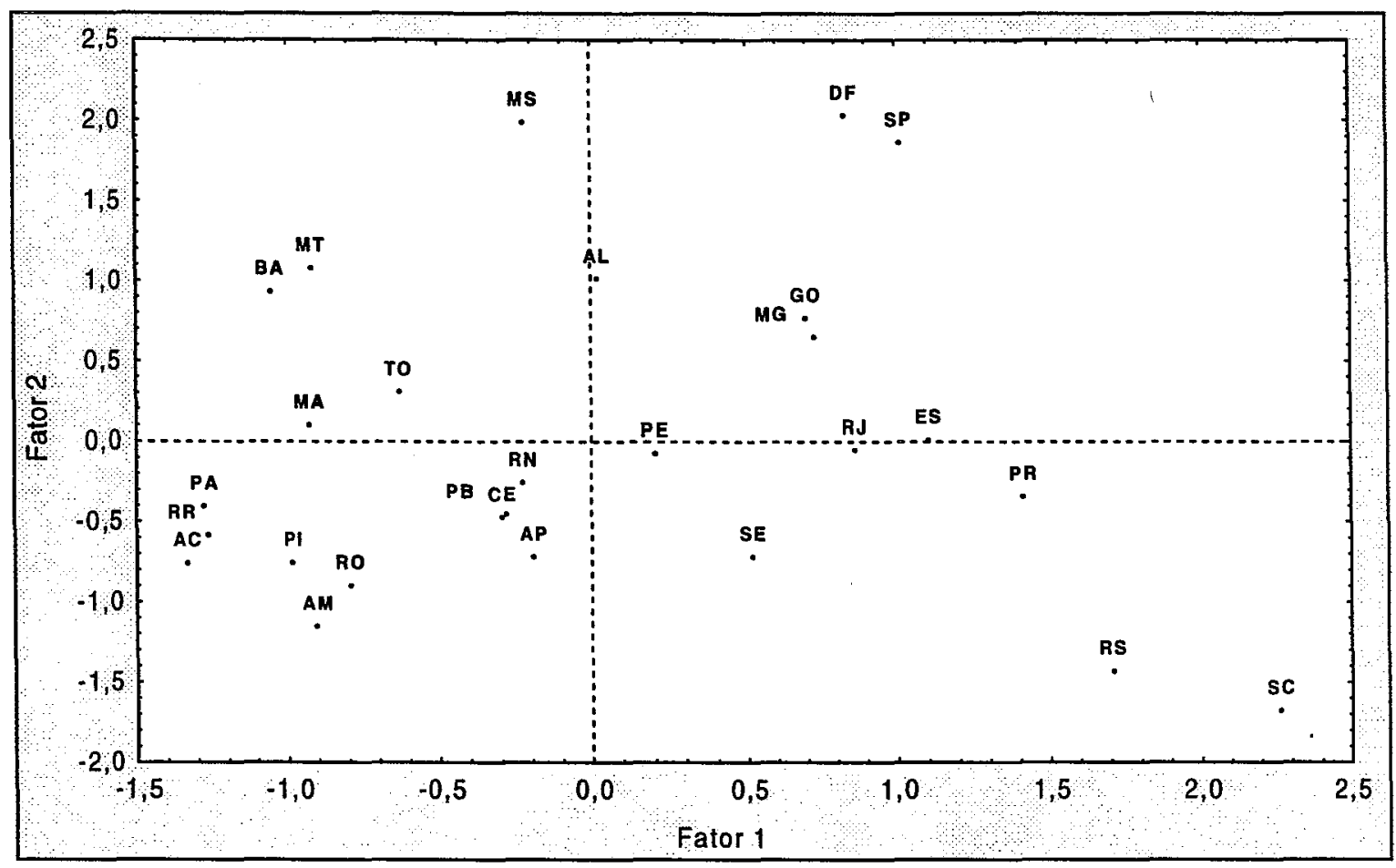

Figura 5 . Coordenadas das UF no primeiro plano fatorial.

Fonte: dados da pesquisa.

As matrizes originais utilizadas na análise de componentes principais foram submetidas a processo de classificação e agrupamento das observações.

Inicialmente, foi aplicado um procedimento de classificação hierárquica direta, obtendo-se o dendrograma dos indivíduos (Unidades da Federação) caracterizados pelas catorze variáveis escolhidas, utilizando-se o critério de encadeamento pela média. Este critério baseia-se na minimização da inércia intraclasses ou maximização da inércia interclasse.

Citado método permite que sejam obtidas melhoras sucessivas da partição inicial, até que se alcance uma partição de qualidade ótima para o critério de homogeneidade das classes. 
O método de classificação hierárquica mostrou que a melhor qualidade de partição consiste no agrupamento dos indivíduos (Unidades da Federação) em cinco classes, conforme sugere o dendrograma apresentado na Figura 6.

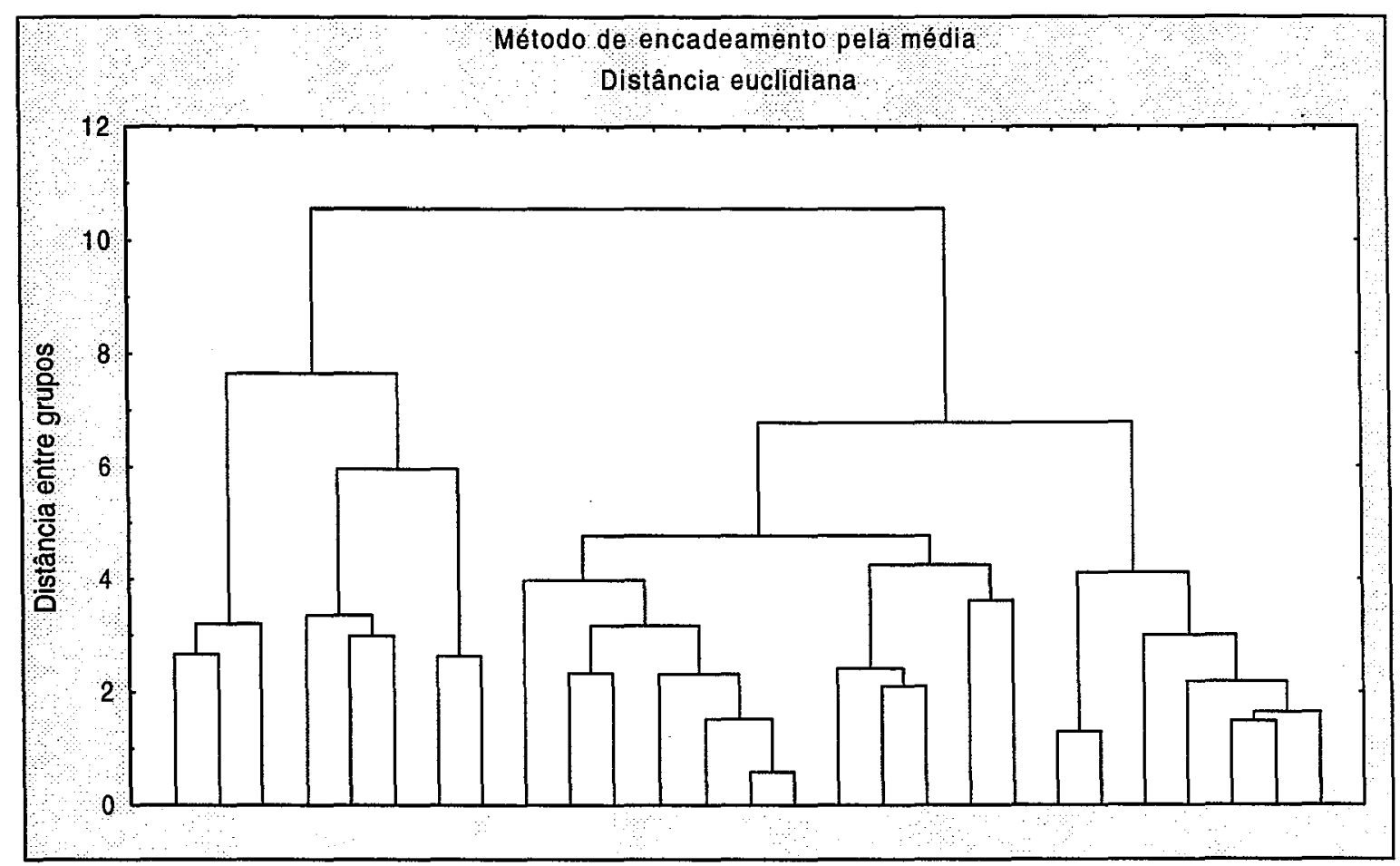

Figura 6. Dendrograma das Unidades da Federação.

Fonte: dados da pesquisa.

Os resultados analíticos encontram-se dispostos no Anexo 12, que indica a participação das classes e a distância de cada indivíduo ao baricentro do grupo.

Conforme apresentado no Quadro 7, a primeira região reúne cinco estados: Goiás, Mato Grosso, Espírito Santo, Minas Gerais e Rio de Janeiro. Esse aglomerado apresenta nível tecnológico modernizado, com destaque para os estados de Goiás e Minas Gerais que levam vantagem relativa por estarem mais afastados da média da classe, pois possuem coordenadas mais elevadas nos dois primeiros eixos fatoriais. 


\begin{tabular}{|c|c|l|}
\hline Região & $n^{\circ}$ de estados & Unidades da Federação \\
\hline 1 & 5 & MG, RJ, ES, MT, GO \\
\hline 2 & 9 & CE, AL, RN, SE, BA, MA, PB, PE, TO \\
\hline 3 & 3 & SP, MS, DF \\
\hline 4 & 7 & AC, PI, AM, AP, PA, RO, RO \\
\hline 5 & 3 & SC, PR, RS \\
\hline
\end{tabular}

Quadro 7. Composição das classes regionais a partir dos eixos fatoriais. Fonte: dados da pesquisa.

A segunda região agrega os estados do Nordeste, exceto Piauí, e o estado de Tocantins. Em média, constata-se relativo atraso tecnológico das unidades deste grupo em relação às regiões 1,3 e 5 . Como conseqüência disto, a produtividade do trabalho representa apenas $23,9 \%$ do desempenho que se verifica nos estados de São Paulo, Mato Grosso do Sul e Distrito Federal. Na região 2, menos de $3 \%$ dos estabelecimentos rurais são filiados a cooperativas, contra $37,2 \%$ da região 5 e $28,2 \%$ da região 3 .

$\mathrm{Na}$ terceira região estão reunidos os estados de São Paulo e Mato Grosso do Sul e o Distrito Federal. Considerando que estes estados estão fortemente correlacionados com o primeiro eixo fatorial, pode-se afirmar esses espaços geoeconômicos são os mais modernos do País, pois adotam intensivamente inovações químicas e mecânicas que permitem a obtenção de elevadas produtividades $(58,2 \%$ das unidades produtivas utilizam tratar, $80,6 \%$ possuem energia elétrica e $69,3 \%$ têm acesso a serviços de assistência técnica) É neste grupamento que se observa a mais alta proporção de estabelecimentos rurais administrados por terceiros, cerca de $15,9 \%$, e também a maior incidência de trabalhadores contratados e empregados permanentes que representam, respectivamente, $65,0 \%$ e $49,1 \%$ da população ocupada.

A quarta região congrega os estados do Norte brasileiro, exceto Tocantins, e o estado do Piauí. As baixas coordenadas desses estados nos dois primeiros eixos fatoriais, colocam-nos na condição de mais atrasados do 
País. São traços marcantes desse grupo: baixa produtividade do trabalho, que representa somente $14,3 \%$ do índice observado no grupo de estados mais avançados; predomínio do uso de mão-de-obra familiar, que alcança $77,2 \% \%$ da população ocupada; e emprego incipiente de técnicas modernas de produção. O nível de filiação ao cooperativismo é semelhante ao observado nos estados do Nordeste.

A última região agrega os estados do Paraná, Santa Catarina e Rio Grande do Sul. Estes estados possuem nível tecnológico acima da média nacional, estando o Paraná melhor posicionado. $O$ traço marcante desse grupo está no fato de referidos estados possuírem elevada coordenada no terceiro eixo fatorial, denotando que as unidades produtivas rurais têm acesso privilegiado a mecanismos de financiamento.

Na região 5, registram-se o maior nível de adesão ao cooperativismo do País e a menor proporção de empregados permanentes em relação à população ocupada entre os estados que possuem agricultura moderna.

No Anexo 13, é apresentado um quadro-resumo das principais características das cinco regiões aqui tratadas e das macrorregiões geográficas brasileiras, segundo as cartoze variáveis consideradas no estudo.

\subsection{Descrição da agricultura cooperativa nordestina}

O cooperativismo possui expressiva participação na agropecuária brasileira, notadamente nas regiōes Sul e Sudeste, onde mais da metade do valor bruto da produção agropecuária provém de agricultores filiados a cooperativas, situando-se a média nacional em $41,2 \%$, conforme disposto na Tabela 5. 
Tabela 5. Valor da produção agropecuária cooperativa.

\begin{tabular}{lrrrrr} 
& & & \multicolumn{4}{c}{ Valores em R\$ mil } \\
\hline Região & $\begin{array}{c}\text { Agricultura } \\
\text { cooperativa (A) }\end{array}$ & $\%$ & $\begin{array}{c}\text { Agricultura } \\
\text { brasileira(B) }\end{array}$ & $\%$ & (A/B) \\
\hline Centro-oeste & 2.141 .857 & 10,9 & 6.884 .856 & 14,4 & 31,1 \\
Nordeste & 985.152 & 5,0 & 7.043 .799 & 14,7 & 14,0 \\
Norte & 142.595 & 0,7 & 2.321 .939 & 4,9 & 6,1 \\
Sudeste & 8.299 .043 & 42,2 & 16.534 .398 & 34,6 & 50,2 \\
Sul & 8.117 .572 & 41,2 & 15.003 .252 & 31,4 & 54,1 \\
\hline Brasil & 19.686 .219 & 100,0 & 47.788 .244 & 100,0 & 41,2 \\
\hline
\end{tabular}

Fonte: Censo Agropecuário 1995-96 do IBGE.

\subsubsection{Valor da produção agropecuária cooperativa nordestina}

No Nordeste, a participação de associados de cooperativas na formação da renda agropecuária é menos expressiva, alcançando apenas $14,7 \%$ do conjunto da economia agrícola regional.

A produção agropecuária cooperada no Nordeste concentra-se em estabelecimentos com área entre 50 hectares e 1.000 hectares, que são responsáveis por $53,3 \%$ do valor bruto da produção agrícola e animal.

Contudo, um rápido exame da Tabela 6 aponta que os pequenos produtores (área até 50 hectares) e os grandes produtores (área superior a 1.000 hectares) têm participação expressiva, respectivamente, 22,1\% e 24,6\%, fato que demonstra relativo equilíbrio na distribuição da renda quanto ao perfil fundiário. 
Tabela 6. Valor da produção agropecuária por estrato de área.

\begin{tabular}{lcrr}
\hline $\begin{array}{c}\text { Grupo de Área } \\
\text { (ha) }\end{array}$ & $\begin{array}{c}\text { Valor da produção } \\
\text { (R\$ 1.000) }\end{array}$ & $\%$ & \multicolumn{1}{c}{$\begin{array}{r}\text { Valor médio } \\
\text { (R\$ 1.000) }\end{array}$} \\
\hline$<10$ & 80.839 & 8,2 & 3.085 \\
$>10<50$ & 136.582 & 13,9 & 6.757 \\
$>50<200$ & 203.430 & 20,7 & 16.461 \\
$>200<1.000$ & 320.931 & 32,6 & 54.898 \\
$>1.000$ & 242.476 & 24,6 & 230.710 \\
\hline Total & 985.152 & 100,0 & 15.000 \\
\hline
\end{tabular}

Fonte: Censo Agropecuário 1995-96 do IBGE.

A renda média obtida por estabelecimento agropecuário filiado a cooperativas revela-se muito acima da verificada no meio rural nordestino para todos os grupos de área.

Os produtores nordestinos associados a cooperativas ocupam-se preponderantemente da agricultura e da pecuária, segundo a distribuição contida na Tabela 7.

Tabela 7. Valor da produção agropecuária cooperativa por atividade econômica.

\begin{tabular}{lcc}
\hline Grupo de Atividade econômica & $\begin{array}{c}\text { Valor da produção } \\
\text { (R\$ 1.000) }\end{array}$ & $\%$ \\
\hline Lavouras & 561.783 & 57,0 \\
Temporárias & 425.341 & 43,2 \\
Permanentes & 136.442 & 13,8 \\
Pecuária & 321.303 & 32,6 \\
Produção mista (lavouras e pecuária) & 87.958 & 8,9 \\
Outras & 14.108 & 1,4 \\
\hline Total & 985.152 & 100,0 \\
\hline
\end{tabular}

Fonte: Censo Agropecuário 1995-96 do IBGE. 


\subsubsection{Estrutura fundiária da agricultura cooperativa nordestina}

No Nordeste, os produtores filiados a cooperativas exploram 65.679 estabelecimentos rurais, cuja área total alcança 78,3 milhões de hectares. Em termos relativos, o cooperativismo compreende, respectivamente, $2,8 \%$ do número de estabelecimentos rurais e $8,8 \%$ das terras agrícolas da região.

O exame dos dados da Tabela 8 permite constatar a enorme desigualdade na distribuição de terras, com o agravante de que quase $40 \%$ dos estabelecimentos rurais de cooperados são constituídos de minifúndios, sendo um quarto deles com área inferior a dois hectares. Portanto, são glebas de terra insuficientes para garantir a subsistência e progresso social e econômico de uma unidade de produção rural nas condições estabelecidas no Estatuto da Terra ao definir o módulo rural (Marques, 1998). Na oportunidade, cumpre lembrar que o módulo fiscal médio está dimensionado em 14 ha., 35 ha. e 70 ha., respectivamente, para os municípios situados na Zona da Mata, Agreste e Sertão do Nordeste.

Tabela 8. Estabelecimentos rurais filiados a cooperativas no Nordeste.

\begin{tabular}{lrrrrrr}
\hline Grupo de Área (ha) & Número & $\%$ & $\% A C$ & Área (ha) & $\%$ & $\% A C$ \\
\hline$<10$ & 26.202 & 39,9 & 39,9 & 101.634 & 1,5 & 1,5 \\
$>10<50$ & 20.221 & 30,8 & 70,7 & 488.869 & 7,1 & 8,6 \\
$>50<200$ & 12.358 & 18,8 & 89,5 & 1.191 .774 & 17,3 & 25,9 \\
$>200<1.000$ & 5.846 & 8,9 & 98,4 & 2.429 .829 & 35,3 & 61,2 \\
$>1.000$ & 1.051 & 1,6 & 100 & 2.669 .669 & 38,8 & 100 \\
\hline Total & 65.678 & 100 & & 6.881 .775 & 100 & \\
\hline
\end{tabular}

Fonte: Censo Agropecuário 1995-96 do IBGE.

Os 6.897 estabelecimentos com área superior a 200 hectares ocupam $74,1 \%$ das terras agrícolas. Igualmente não desprezível é o volume de terras ocupadas por grandes proprietários (acima de 1.000 ha.), cerca de 38,8\%. Cumpre destacar que se incluem neste estrato 30 propriedades com área superior a 10.000 ha. Há certo equilíbrio no estrato de propriedades com área 
entre 50 ha. e 200 ha., que representa 18,8\% do número de estabelecimentos rurais e $17,3 \%$ da área ocupada.

Em suma, a estrutura fundiária no cooperativismo nordestino pode ser melhor retratada pela leitura das medidas de desigualdade apresentadas na Tabela 9, em que se compara o perfil das propriedades filiadas a cooperativas ao perfil dos demais estabelecimentos agropecuários existentes.

Tabela 9. Indicadores de desigualdade na estrutura fundiária da agricultura cooperativa nordestina.

\begin{tabular}{lcc}
\hline Indicador & $\begin{array}{c}\text { Agricultura } \\
\text { cooperativa }\end{array}$ & $\begin{array}{c}\text { Agricultura } \\
\text { não-cooperativa }\end{array}$ \\
\hline Índice de Gini & 0,821 & 0,856 \\
Índice de Theil & 0,829 & 0,894 \\
Proporção de minifúndios & 0,399 & 0,680 \\
Participação dos $50^{-}$ & 0,027 & 0,021 \\
Participação dos $20^{+}$ & 0,857 & 0,895 \\
Participação dos $10^{+}$ & 0,731 & 0,790 \\
Participação dos $1^{+}$ & 0,321 & 0,421 \\
\hline
\end{tabular}

Fonte: Censo Agropecuário 1995-96 do IBGE.

Referidos números revelam que a estrutura fundiária entre os produtores filiados a cooperativas não é muito diferente da observada para o restante da agricultura nordestina.

\subsubsection{Condição do responsável pela exploração na agricultura cooperativa nordestina}

No cooperativismo nordestino predomina a classe de proprietários que representa $81,1 \%$ do número de estabelecimentos e $96,3 \%$ da área ocupada, conforme se vê na Tabela 10. Esta estrutura provavelmente deve-se ao fato de - cooperativismo exigir prévia acumulação de capital para sua constituição, mesmo na hipótese de financiamento para integralização cotas-partes, pois, em geral, os bancos exigem garantias reais preexistentes. 
Tabela 10. Condição do responsável pela exploração na agricultura cooperativa nordestina.

\begin{tabular}{lcc}
\hline Condição do produtor & Proporção do número & Proporção da área \\
\hline Proprietário & $81,1 \%$ & $96,3 \%$ \\
Arrendatário & $3,3 \%$ & $1,3 \%$ \\
Parceiro & $2,8 \%$ & $0,4 \%$ \\
Ocupante & $12,8 \%$ & $2,0 \%$ \\
\hline
\end{tabular}

Fonte: Censo Agropecuário 1995-96 do IBGE.

\subsubsection{Utilização da terra na agricultura cooperativa nordestina}

Os dados da Tabela 11 revelam que entre os produtores cooperados há intenso nivel de ocupação do solo.

\section{Tabela 11. Uso da terra na agricultura cooperativa nordestina.}

\begin{tabular}{lrr}
\hline Categorias & Área (ha) & $\%$ \\
\hline Área em estabelecimentos & 6.881 .775 & 100,0 \\
Área aberta & 3.146 .753 & 45,7 \\
Área em lavouras temporárias & 840.305 & 12,2 \\
Área em lavouras permanentes & 279.185 & 4,1 \\
Pastagens plantadas & 1.167 .523 & 17,0 \\
Matas plantadas & 28.196 & 0,4 \\
Área em descanso & 299.384 & 4,4 \\
Área produtiva não-utilizada & 532.160 & 7,7 \\
Pastagens naturais & 1.920 .118 & 27,9 \\
Matas naturais & 1.550 .992 & 22,5 \\
Terras inaproveitáveis & 263.912 & 3,8 \\
\hline
\end{tabular}

Fonte: Censo Agropecuário 1995-96 do IBGE.

\subsubsection{Principais lavouras cultivadas na agricultura cooperativa nordestina}

Os produtores rurais nordestinos filiados a cooperativas concentram sua produção em dois grupos principais de lavouras, que juntos representam cerca de $75,9 \%$ do valor da produção agrícola. De um lado, têm-se as culturas 
comerciais: cana-de-açúcar, cacau e soja exploradas em zonas vocacionadas. Por outro, as lavouras mais tradicionais: milho, feijão e arroz.

$\mathrm{Na}$ tabela 12, estão relacionadas as culturas de maior expressão econômica. A lavoura de cana-de-açúcar, que sozinha representa 52,8\% da produção vegetal e $28,8 \%$ do valor da produção agropecuária dos produtores filiados a cooperativas, está localizada nos estados de Pernambuco e de Alagoas, os quais reúnem $91,6 \%$ de toda a produção. É oportuno chamar a atenção para o fato de que referida atividade econômica mantém pouca associação com os negócios das cooperativas nordestinas, visto que $93,2 \%$ desse produto destinam-se às usinas de fabricação de açúcar e álcool e apenas $1,8 \%$ circula pelas cooperativas.

Tabela 12. Produção vegetal da agricultura cooperativa nordestina.

\begin{tabular}{lrrrrrr}
\hline Lavoura & $\begin{array}{c}\text { Área } \\
\text { (hectare) }\end{array}$ & $\%$ & $\begin{array}{c}\text { Quantidade } \\
\text { produzida } \\
\text { (tonelada) }\end{array}$ & $\begin{array}{c}\text { Quantidade } \\
\text { vendida } \\
\text { (tonelada) }\end{array}$ & $\begin{array}{c}\text { Valor da } \\
\text { produção } \\
\text { (R\$ 1.000) }\end{array}$ & $\%$ \\
\hline Cana-de-açúcar & 255.35 & 22,9 & 13.963 .516 & 13.860 .343 & 283.519 & 52,8 \\
Soja & 79.077 & 7,1 & 165.994 & 163.838 & 34.760 & 6,5 \\
Cacau & 79.119 & 7,1 & 28.858 & 28.619 & 29.513 & 5,5 \\
Milho & 135.698 & 12,1 & 150.957 & 98.743 & 23.816 & 4,4 \\
Feijão & 112.374 & 10,0 & 41.958 & 26.972 & 21.366 & 4,0 \\
Banana & 11.142 & 1,0 & 10.096 & 9.339 & 19.352 & 3,6 \\
Arroz & 37.270 & 3,3 & 70.552 & 51.134 & 14.706 & 2,7 \\
Manga & 3.472 & 0,3 & 71.801 & 55.126 & 14.059 & 2,6 \\
Café & 14.742 & 1,3 & 15.208 & 2.260 & 12.804 & 2,4 \\
Uva & 827 & 0,1 & 13751 & 13.751 & 11.766 & 2,2 \\
Melão & 2.211 & 0,2 & 29.042 & 28.949 & 11.584 & 2,2 \\
Tomate & 1.922 & 0,2 & 43.844 & 43.158 & 10.599 & 2,0 \\
Outros & 385.701 & 34,5 & - & - & 49.501 & 9,3 \\
\hline Total & 1.119 .490 & 100,0 & - & - & 537.345 & 100,0 \\
\hline
\end{tabular}

Fonte: Censo Agropecuário 1995-96 do IBGE.

Tratando ainda sobre a lavoura de cana-de-açúcar, cumpre destacar que sua exploração é conduzida por produtores de maior porte. Cerca de $49,2 \%$ 
da produção origina-se de grupos de área colhida superior a 500 ha., ao passo que grupos de área colhida inferior a 10 ha. produzem apenas $2,1 \%$.

De forma semelhante, a cultura de soja também é explorada por grandes produtores. Os estratos de área colhida superior a 200 ha. ofertam $93,9 \%$ da soja em grãos. Do ponto de vista espacial, a produção está localizada nos cerrados da Bahia, do Maranhão e do Piauí, que produzem quase toda a soja de cooperados nordestinos.

A cultura de cacau está integralmente localizada no estado da Bahia, concentrando-se $77,6 \%$ de sua produção nos estratos de área colhida entre 10 ha. e 200 ha.

As lavouras de milho, feijão e arroz são exploradas em pequenas áreas. Com efeito, a participação de estratos de área colhida até 50 ha. representa, respectivamente, $47 \%, 82 \%$ e $72 \%$ da produção dessas lavouras. Os plantios de milho e feijão estão regularmente distribuídos em quase toda a região, enquanto o plantio de arroz localiza-se nos vales úmidos e nos cerrados. Ceará, Bahia e Maranhão concentram $70 \%$ do arroz produzido por cooperados, destacando que os perímetros públicos de irrigação são responsáveis por cerca de $40 \%$ da oferta do produto.

A ocorrência de pragas exóticas e a frágil relação institucional entre indústria de beneficiamento e agricultores provocaram expressiva queda na produção de algodão no Nordeste. Entre 1985 e 1995, houve redução de 90,0\% da área colhida e de $85,6 \%$ do volume produzido. A produção física caiu de 547,6 mil toneladas para 78,8 mil toneladas.

Os impactos da decadência do algodão nas cooperativas foram imediatos, visto que estas possuíam "pesadas" estruturas voltadas para o descaroçamento, extração de óleos, bem como para a comercialização e transporte desse produto. 
Estima-se que hoje existem 65 indústrias de algodão desativadas na região nordeste, sem que tenham sido adotadas efetivas políticas públicas no sentido de reconversão da base produtiva dos produtores envolvidos.

Tomando-se com base um grupo de lavouras que juntas representam $92 \%$ do valor da produção vegetal, verifica-se que apenas $10,5 \%$ da produção de associados são comercializados por cooperativas. Agroindústrias nãocooperativas absorvem $55,3 \%$ dos bens produzidos, enquanto agentes intermediários ficam com $23,8 \%$. Cerca de $8,1 \%$ dos bens produzidos são consumidos na propriedade, restando $2,3 \%$ que tomam outros destinos.

\subsubsection{Atividade pecuária na economia cooperativa nordestina}

No Nordeste brasileiro predomina a pecuária bovina. A criação de animais de pequeno porte, em geral, constitui atividade de subsistência humana, destinando-se eventuais excedentes para os mercados locais.

Na pecuária cooperativa, o rebanho bovino totaliza cerca de 2,5 milhões de cabeças, equivalentes a $10,9 \%$ do efetivo nordestino. Apenas $32,1 \%$ do rebanho são especializados na produção de leite. $60,2 \%$ destinam-se a corte; 0 restante é gado sem especialização e animais de trabalho.

Na pecuária, as funções das cooperativas limitam-se à comercialização de leite resfriado e em alguns casos à industrialização dessa matéria-prima.

\subsubsection{Valor adicionado da agricultura cooperativa nordestina}

Os dados da Tabela 13 evidenciam que entre os produtores filiados a cooperativas no Nordeste, a renda agropecuária é, expressivamente, superior a dos demais produtores rurais, em todos os grupos de área considerados. 
Tabela 13. Renda agropecuária média comparada de produtores cooperados e não-cooperados na região Nordeste.

Valores em $\mathrm{R} \$ 1,00$

\begin{tabular}{lccc}
\hline $\begin{array}{l}\text { Grupo de Área } \\
\text { (ha) }\end{array}$ & $\begin{array}{c}\text { (A) Produtores } \\
\text { Cooperados }\end{array}$ & $\begin{array}{c}\text { (B) Produtores } \\
\text { Não-cooperados }\end{array}$ & A/B \\
\hline$<1$ & 737 & 345 & 2,14 \\
$>1<2$ & 624 & 427 & 1,46 \\
$>2<5$ & 1.058 & 660 & 1,60 \\
$>5<10$ & 2.191 & 958 & 2,29 \\
$>10<20$ & 2.202 & 1.188 & 1,85 \\
$>20<50$ & 2.894 & 1.561 & 1,85 \\
$>50<100$ & 4.733 & 2.261 & 2,09 \\
$>100<200$ & 8.718 & 3.431 & 2,54 \\
$>200<500$ & 16.476 & 7.390 & 2,23 \\
$>500<1.000$ & 31.743 & 15.166 & 2,09 \\
$>1.000<2.000$ & 56.333 & 23.685 & 2,38 \\
$>2.000<5.000$ & 97.669 & 52.573 & 1,86 \\
$>5.000<10.000$ & 575.291 & 189.511 & 3,04 \\
$>10.000$ & 232.989 & 191.283 & 1,22 \\
\hline Média geral & 6.054 & 1.321 & 4,58 \\
\hline
\end{tabular}

Fonte: Censo Agropecuário 1995-96 do IBGE.

Esta performance é também observada no restante do País, em que a renda dentro do cooperativismo mostra-se, em média, $180 \%$ maior que a verificada entre os produtores não-filiados a cooperativas.

A explicação para este fenômeno pode ser atribuída ao fato de ser a cooperativa uma organização que procura maximizar os serviços prestados, oferecendo, possivelmente, aos seus sócios condições materiais não acessiveis aos demais produtores. Esta condição é compatível e confirma as previsões do modelo microeconômico proposto por Sexton (1986).

Outra tese que merece investigação posterior, mas que se mostra razoável para justificar o melhor desempenho dos produtores cooperados, seja o fato de as ações governamentais serem prioritariamente dirigidas ao produtor 
rural por intermédio de suas organizações cooperativas. Então, nesta hipótese, estar-se-ia diante de um grupo privilegiado, cujas demandas socioeconômicas são apoiadas por políticas compensatórias.

\subsubsection{Pessoal ocupado na agricultura cooperativa nordestina}

O cooperativismo nordestino proporciona ocupação a 359.312 pessoas, das quais 124.417 são membros não-remunerados da família, 68.122 são empregados permanentes, 82.767 empregados temporários, 7.949 trabalham como parceiros e 14.809 estão enquadrados em outras condições de trabalho. $\mathrm{Na}$ Tabela 14, é apresentada a distribuição espacial da força de trabalho do cooperativismo do Nordeste. A maioria da população ocupada no cooperativismo nordestino, cerca de $57 \%$, reside no meio rural.

Tabela 14. Pessoal ocupado na agricultura cooperativa nordestina.

\begin{tabular}{lcc} 
& \multicolumn{2}{c}{ Valores em unidades } \\
\hline UF & Pessoal ocupado & $\%$ \\
\hline Bahia & 76.637 & 21,3 \\
Ceará & 67.318 & 18,7 \\
Alagoas & 51.856 & 14,4 \\
Rio Gde. Norte & 48.481 & 13,5 \\
Pernambuco & 41.592 & 11,6 \\
Paraíba & 36.184 & 10,1 \\
Piauí & 14.899 & 4,1 \\
Maranhão & 14.412 & 4,0 \\
Sergipe & 7.933 & 2,2 \\
\hline Nordeste & 359.312 & 100,0 \\
\hline
\end{tabular}

Fonte: Censo Agropecuário 1995-96 do IBGE.

$\mathrm{Na}$ agricultura cooperativa nordestina, $48,3 \%$ das pessoas ocupadas são empregados, sendo $19,0 \%$ em caráter permanente. Estes números revelam que o sistema produtivo sob enfoque reúne características dominantes de agricultura comercial, contrastando com a situação dos estados sulinos, onde a agricultura se modernizou sem o assalariamento da força de trabalho. Na região 
Sul, somente $20 \%$ das pessoas ocupadas na agricultura cooperativa são empregadas, das quais $9,7 \%$ delas em regime permanente.

\subsubsection{Assistência técnica na agricultura cooperativa nordestina}

O acesso a serviços de assistência técnica é, incontestavelmente, mais amplo dentro do cooperativismo (Tabela 15). Os comentários feitos na seção 4.3.7, in fine, aplicam-se, certamente, na justificação do tratamento diferenciado dispensado ao produtor cooperado.

Tabela 15. Proporção de estabelecimentos
agropecuários beneficiados por
serviços de assistência técnica.

\begin{tabular}{lcc}
\hline $\begin{array}{l}\text { Grupo de Área } \\
\text { (ha) }\end{array}$ & $\begin{array}{c}\text { Produtores } \\
\text { Cooperados }\end{array}$ & $\begin{array}{c}\text { Produtores } \\
\text { Não-cooperados }\end{array}$ \\
\hline$<10$ & $27,7 \%$ & $4,1 \%$ \\
$>10<50$ & $24,6 \%$ & $5,1 \%$ \\
$>50<200$ & $29,2 \%$ & $8,3 \%$ \\
$>200<1000$ & $44,6 \%$ & $17,6 \%$ \\
+1000 & $62,8 \%$ & $33,5 \%$ \\
\hline
\end{tabular}

Fonte: Censo Agropecuário 1995-96 do IBGE.

Cumpre ainda destacar que, além da diferença entre produtores cooperados e não-cooperados, o acesso a serviços de orientação técnica cresce à medida que aumenta no tamanho do imóvel.

\subsubsection{Distribuição espacial do cooperativismo agropecuário nordestino}

O cooperativismo distribui-se em todos os Estados do Nordeste, quase que proporcionalmente às suas extensões territoriais. Bahia e Ceará possuem juntos $50 \%$ da área ocupada e $42 \%$ dos estabelecimentos dos produtores cooperativados, conforme apresentado na Tabela 16. 
Tabela 16. Distribuição espacial do cooperativismo nordestino.

\begin{tabular}{lcrrr}
\hline Estado & Esiabelecimento & \multicolumn{1}{c}{$\%$} & \multicolumn{1}{c}{ Área } & $\%$ \\
\hline Bahia & 13.852 & 21,1 & 2.534 .029 & 36,8 \\
Ceará & 13.738 & 20,9 & 911.345 & 13,2 \\
R.G. Norte & 9.373 & 14,3 & 934.091 & 13,6 \\
Paraíba & 7.690 & 11,7 & 590.143 & 8,6 \\
Pernambuco & 7.083 & 10,8 & 376.590 & 5,5 \\
Alagoas & 5.562 & 8,5 & 505.378 & 7,3 \\
Piauí & 3.936 & 6,0 & 466.942 & 6,8 \\
Maranhão & 2.701 & 4,1 & 521.683 & 7,6 \\
Sergipe & 1.743 & 2,7 & 41.574 & 0,6 \\
\hline Nordeste & 65.678 & 100,0 & 6.881 .775 & 100,0 \\
\hline
\end{tabular}

Fonte: Censo Agropecuário 1995-96 do IBGE.

Em termos relativos, o cooperativismo destaca-se com participação mais expressiva na agricultura dos estados de Alagoas e do Rio Grande do Norte, em que, respectivamente, participa com $39,7 \%$ e $24,2 \%$ de toda a produção agropecuária (Tabela 17).

Tabela 17. Valor da produção agropecuária cooperativa nordestina por Estado.

Valor R\$ mil

\begin{tabular}{lrrrrr}
\hline Estado & (A)Coop. & \multicolumn{1}{c}{$\%$} & (B) Nordeste & \multicolumn{1}{c}{$\%$} & \multicolumn{1}{c}{ A/B } \\
\hline Alagoas & 259.901 & 26,4 & 654.670 & 9,3 & 39,7 \\
Bahia & 222.485 & 22,6 & 2.102 .240 & 29,8 & 10,6 \\
Pernambuco & 134.222 & 13,6 & 1.229 .492 & 17,5 & 10,9 \\
Ceará & 125.535 & 12,7 & 919.171 & 13,0 & 13,7 \\
R.G. Norte & 86.055 & 8,7 & 355.930 & 5,1 & 24,2 \\
Paraíba & 64.498 & 6,5 & 468.349 & 6,6 & 13,8 \\
Maranhão & 39.071 & 4,0 & 698.162 & 9,9 & 5,6 \\
Piauí & 32.330 & 3,3 & 342.258 & 4,9 & 9,4 \\
Sergipe & 21.056 & 2,1 & 273.526 & 3,9 & 7,7 \\
\hline Nordeste & 985.153 & 100,0 & 7.043 .798 & 100,0 & 14,0 \\
\hline
\end{tabular}

Fonte: Censo Agropecuário 1995-96 do IBGE.

O desempenho de Alagoas é surpreendente à medida que sua participação no número de imóvel é modesta $(8,5 \%)$ e detém não mais que $7,3 \%$ das terras ocupadas, merecendo, portanto, investigação futura de pesquisa de escopo menos agregado. 


\section{CARACTERIZAÇÃO DAS COOPERATIVAS AGROPECUÁRIAS NORDESTINAS}

Neste capítulo é exposto um quadro descritivo que reflete a situação agregada das 40 cooperativas constituintes da amostra coletada, as quais se encontram relacionadas no Anexo 1.

Na última seção do capítulo é relatado, com maior detalhe, o caso de uma cooperativa agropecuária mista que, pelo seu perfil organizacional e mercadológico, pode ser classificada como típica na região Nordeste. Com essa medida, buscou-se transmitir informações mais próximas da realidade do cooperativismo agropecuário nordestino.

\subsection{Análise do ambiente das cooperativas agropecuárias nordestinas}

Segundo Chiavenato (1999a), as organizações modernas são influenciadas pelo ambiente e interagem entre si, constantemente, podendo em certas situações intervir na construção das próprias regras institucionais, na tentativa de alterá-las em seu favor. Portanto, é insuficiente avaliar isoladamente o comportamento ou o desempenho de um setor ou empresa.

Certo \& Peter (1993) definem análise de ambiente como o processo de monitoração do ambiente organizacional empregado para identificar os riscos e oportunidades, tanto presentes quanto futuros, que possam influenciar a capacidade das empresas de atingir suas metas.

A análise de ambiente está orientada para a formulação de políticas gerais da organização, quando se foca em aspectos estratégicos amplos. Neste 
caso, geralmente, é pouco estruturada e restringe-se à competência da alta direção da empresa. Num segundo estrato, referida técnica é dirigida para fundamentar o planejamento estratégico operacional, com vistas a melhorar o desempenho organizacional, ou pode ainda ser orientada para certas funções da empresa, quando se torna de caráter mais específico (Chiavenato, 1999a).

Feitas essas considerações introdutórias, apresenta-se, nas Tabelas $18,19,20$ e 21 , a percepção das cooperativas nordestinas quanto a fatores de ordem interna e externa à organização.

Tabela 18. Principais oportunidades identificadas pelas cooperativas agropecuárias do Nordeste.

\begin{tabular}{lc}
\hline Fatores percebidos & $\%$ \\
\hline $\begin{array}{l}\text { Possibilidade de acesso a crédito de longo prazo, especialmente da } \\
\text { fonte FNE }\end{array}$ & 92,5 \\
Estabilização monetária & 67,5 \\
Programas de compras governamentais & 57,5 \\
Programas de aquisição de sementes instituídos por governos & 35,0 \\
\hline
\end{tabular}

Fonte: dados da pesquisa.

Tabela 19. Principais ameaças identificadas pelas cooperativas agropecuárias do Nordeste.

\begin{tabular}{lc}
\hline Fatores percebidos & $\%$ \\
\hline Elevado custo de capital & 87,5 \\
Dificuldade de obtenção de crédito & 80,0 \\
Recorrentes ocorrências de estiagens prolongadas & 77,5 \\
Ação de intermediários no comércio agropecuário & 62,5 \\
Instalação de grandes agroindústrias na região & 47,5 \\
\hline
\end{tabular}

Fonte: dados da pesquisa. 
Tabela 20. Principais pontos fortes identificados pelas cooperativas agropecuárias do Nordeste.

\begin{tabular}{lc}
\hline Fatores percebidos & $\%$ \\
\hline Escala de produção e comercialização & 85,0 \\
Localização próxima a centros consumidores & 72,5 \\
Estrutura de armazenamento & 65,0 \\
Facilidade de acesso a matérias-primas & 52,5 \\
\hline
\end{tabular}

Fonte: dados da pesquisa.

Tabela 21. Principais pontos fracos identificados pelas cooperativas agropecuárias do Nordeste.

\begin{tabular}{lc}
\hline Fatores percebidos & $\%$ \\
\hline Alto custo de capital & 95,0 \\
Elevado nivel de endividamento e de custo de capital & 90,0 \\
Deficiente organização de controles operacionais & 82,5 \\
Dificuldades de capitalização por fontes internas & 72,5 \\
Deficitária base produtiva dos associados & 67,5 \\
\hline
\end{tabular}

Fonte: dados da pesquisa.

A leitura dos elementos apresentados revela que as cooperativas adotam posição passiva diante das dificuldades vivenciadas e ainda persistem na visão de que ao Estado compete a solução de seus problemas.

Além do acirramento da concorrência e da presença de fatores macroeconômicos desfavoráveis, as mudanças introduzidas na política operacional do Banco do Nordeste (BNB) de apoio ao cooperativismo constituirão nova fonte de ameaça para as cooperativas, dado o seu caráter restritivo.

De acordo com informações prestadas por citada instituição financeira, em virtude de repetidos casos de insucesso, não será permitida a realização de operações de repasse a cooperado por intermédio de cooperativas. Mesmo na hipótese de inversões à própria cooperativa, o financiamento deverá processar- 
se por meio de integralização de cotas-partes, ficando o associado diretamente responsável pelo mútuo.

Para as cooperativas, institucionaliza-se uma situação até então inusitada, cuja legitimidade jurídica é discutível. Entre todas as sociedades civis e comerciais reconhecidas pelo direito positivo brasileiro, as cooperativas serão as únicas empresas a terem acesso limitado ao sistema de crédito público, independentemente da capacidade de pagamento, disponibilidade de garantias e idoneidade administrativa.

As diretrizes estratégicas do Banco do Nordeste, em relação ao cooperativismo agropecuário, apresentam graves equívocos em sua formulação, possivelmente, resultantes de diagnóstico apressado. O novo modelo de concessão de crédito não satisfaz adequadamente aos interesses de ambas as partes envolvidas.

Para o Banco do Nordeste, haverá incremento substancial dos custos operacionais, certamente ainda não avaliados, pois terá de realizar e monitorar numerosa quantidade de pequenas operações. Ademais, a amplitude de controle, exigida para a eficácia das ações de monitorização, demandará capacidade operacional muito superior ao estoque de recursos humanos e logísticos de que dispõe o Banco do Nordeste. A migração do produtor cooperado para o crédito direto é efeito colateral também previsível que poderá causar a amplificação do número de clientes potenciais, para mesma demanda agregada de crédito. Em decorrência de tal situação, é provável que ocorra, em futuro breve, uma explosão de inadimplência no segmento.

As cooperativas identificam como maior concorrente as agroindústrias que atuam no mercado regional. Segundo relato de seus dirigentes, essas empresas dispõem de estrutura organizacional e de capital capazes de atrair os melhores produtores. A Tabela 22 apresenta o ranking dos competidores, segundo a ordem de importância, à luz da percepção das cooperativas. 


\begin{tabular}{|c|c|c|}
\hline Tabela 22. & $\begin{array}{l}\text { Principais } \\
\text { cooperativas } \\
\text { Nordeste. }\end{array}$ & $\begin{array}{cr}\text { concorrentes das } \\
\text { agropecuárias }\end{array}$ \\
\hline \multicolumn{2}{|l|}{ Concorrente } & POSIÇÃO \\
\hline \multicolumn{2}{|c|}{ Agroindústrias regionais } & $1^{\circ}$ \\
\hline \multicolumn{2}{|c|}{ Economia informal } & $2^{\circ}$ \\
\hline \multicolumn{2}{|c|}{ Agroindústrias nacionais } & $3^{\circ}$ \\
\hline \multicolumn{2}{|c|}{ Empresas multinacionais } & $4^{\circ}$ \\
\hline \multicolumn{2}{|c|}{ Outras cooperativas } & $5^{\circ}$ \\
\hline \multicolumn{2}{|c|}{ Produtos importados } & $6^{\circ}$ \\
\hline
\end{tabular}

Fonte: dados da pesquisa.

Em seguida, citam como competidor relevante os intermediários que atuam no mercado informal, adquirindo parcela preponderante da produção dos associados. A vantagem desses agentes de comércio está no fato de possuírem capital de giro disponível, razoável agilidade no que diz respeito à logística de distribuição e, principalmente, conseguirem escapar do recolhimento de tributos.

Essa percepção das cooperativas é confirmada pelos resultados do Censo Agropecuário 1995-96. De acordo com referida fonte, os intermediários dominam expressiva parcela do comércio de produtos da agricultura cooperada, em alguns casos até superando a cooperativa. Podem ser citados os seguintes exemplos: $76 \%$ da produção de banana, $48 \%$ da produção de milho, $21 \%$ da produção de soja, $58 \%$ da produção de feijão e $28 \%$ da produção de mandioca.

Conforme Chiavenato (1999a), a participação de uma organização no mercado impõe a criação e manutenção de uma malha de relacionamentos no interior do ambiente específico no qual ela está inserida. Este ambiente de tarefa é constituído pelos fornecedores, cliente, concorrentes e agências reguladoras. Então, o sucesso de organização depende, em parte, de sua capacidade de interação com os demais agentes institucionais. Assim sendo, espera-se que quanto maior for $a$ intensidade $e$ a extensão dos 
relacionamentos institucionais mantidos pela organização, maiores serão as suas chances de ajustamento às condições ambientais.

Às cooperativas, foi perguntado a freqüência de seu relacionamento com as organizações listadas na Tabela 23. O escore obtido representa a média aritmética do nível de utilização dos serviços atribuídos às referidas organizações, segundo escala graduada com cinco pontos: 1=nunca; 2=ocasionalmente; 3=regularmente; 4=freqüentemente; e 5=sempre.

Tabela 23. Indicação do relacionamento institucional mantido pelas cooperativas agropecuárias do Nordeste.

\begin{tabular}{clc}
\hline Rank & Organização & Escore \\
\hline 1 & Banco do Nordeste (BNB) & 4,83 \\
2 & Sistema OCB/OCE & 3,58 \\
3 & Serviço público de assistência técnica & 2,73 \\
4 & Empresas privadas de assistência técnica & 2,45 \\
5 & Cooperativa Central & 2,38 \\
6 & Empresas de transporte & 2,33 \\
7 & Institutos de pesquisa agropecuária & 2,28 \\
8 & Banco do Brasil & 2,28 \\
9 & Bolsa de mercadorias & 1,93 \\
10 & Empresas de auditoria externa & 1,90 \\
11 & Universidades & 1,73 \\
12 & Empresas de distribuição & 1,58 \\
13 & Empresas de serviços de controladoria & 1,50 \\
14 & Bancos privados & 1,45 \\
15 & Empresas de consultoria & 1,38 \\
\hline
\end{tabular}

Fonte: dados da pesquisa. 
Os resultados acima apresentados indicam que os laços mais fortes de relacionamento das cooperativas são com o BNB, responsável por cerca de $90 \%$ dos créditos concedidos a esse segmento da economia rural nordestina durante a década de noventa. Em seguida, vem o sistema de representação política, constituído pela Organização das Cooperativas Brasileiras e pelas Organizações Estaduais de Cooperativas.

Cabe destacar que o Banco do Brasil, outrora o grande parceiro das cooperativas, ocupa posição intermediária e os bancos privados são praticamente inacessiveis. Nota-se também que os serviços de empresas especializadas em consultorias, controladoria, pesquisa agropecuária e auditoria externa são pouco utilizados.

Segundo relato de dirigentes, a contratação de serviços de elaboração de projetos e de auditoria externa é realizada mais em função de exigências contratuais de credores que por iniciativa própria da cooperativa.

\subsection{Considerações sobre as diretrizes organizacionais das cooperativas agropecuárias nordestinas}

Realizada a análise de ambiente, a empresa está em condições de definir sua missão organizacional, que nada mais é senão uma declaração ampla de sua diretriz organizacional. Portanto, missão organizacional é a proposta pela qual uma organização justifica a sua existência (Chiavenato, 1999a).

A adequada definição da missão é importante visto que esta permite a concentração dos esforços da organização para uma direção convergente, evitando que se persigam propósitos conflitantes.

Assim, com base na missão são estabelecidos os objetivos da empresa e alocados os recursos necessários ao exercício da atividade econômica 
escolhida. Dito de outro modo, objetivos formulados de forma apropriada são consistentes com a missão organizacional.

Certo \& Peter (1993) apresentam oito áreas-chaves para as quais os objetivos organizacionais podem ser conduzidos: participação relativa no mercado, inovação de produtos e processos, produtividade, níveis de recursos, rentabilidade, desempenho e atitudes de administradores e funcionários e responsabilidade social.

Os objetivos das organizações devem precisos e mensuráveis. Os objetivos de curto prazo devem ser compatíveis com os de longo prazo e estes com a missão da organização, incorporando um nível tolerável de esforço. Com vistas a manter a harmonia com o ambiente organizacional, os objetivos devem também possuir flexibilidade suficiente para adaptar-se a eventuais mudanças de rumos (Chiavenato, 1999b).

Feitas as deferências antes adscritas, procurou-se identificar os objetivos norteadores da ação das cooperativas da amostra. O exame da Tabela 24 mostra que as cooperativas têm dificuldade em definir seus objetivos de forma mais restrita e precisa.

Tabela 24. Principais objetivos organizacionais revelados pelas cooperativas agropecuárias do Nordeste.

\begin{tabular}{lc}
\hline Fatores percebidos & $\%$ \\
\hline Contribuir para o aumento da renda média dos sócios & 82,5 \\
Realizar a comercialização da produção dos sócios & 62,5 \\
Fornecer os insumos necessários às atividades desenvolvidas & 60,0 \\
pelos sócios & 55,0 \\
Contribuir para a modernização tecnológica do associado & 45,0 \\
Realizar o beneficiamento da produção do sócio & 22,5 \\
\hline
\end{tabular}

Fonte: dados da pesquisa. 
Os fatores listados, com a indicação de freqüência que aparecem nas respostas dadas à questão aberta, revelam sempre a preocupação da cooperativa em disponibilizar serviços para o associado, de forma que este possa melhorar sua situação econômica. Contudo, falta-Ihe competência para estabelecer concretamente os meios materiais e o horizonte temporal em que as ações derivadas deverão ser realizadas.

\section{3 Área de atuação das cooperativas agropecuárias nordestinas}

Para os fins de interesse deste trabalho, considera-se área de atuação o território de admissão de associados. O conceito (sensu strictu) de área de atuação circunscreve-se aos limites operacionais do ato cooperativo, nada se referindo aos negócios da cooperativa no mercado.

As cooperativas integrantes da amostra atuam, conjuntamente, em 295 municípios nordestinos, com distintas dimensões de base territorial, conforme pode ser visto na Tabela 25.

Tabela 25. Área de atuação das cooperativas agropecuárias do Nordeste.

\begin{tabular}{lc}
\hline Abrangência territorial & $\%$ \\
\hline 1 município & 20,0 \\
2 e 3 municípios & 22,5 \\
4 e 9 municípios & 27,5 \\
Mais de 10 municípios & 30,0 \\
\hline Total & 100,0 \\
\hline
\end{tabular}

Fonte: dados da pesquisa.

As cooperativas cujos sócios estão localizados em raio de ação mais estreito (até três municípios) constituem $42,5 \%$ dos casos identificados. Os traços que caracterizam essas organizações são os seguintes: cooperativas constituídas nos últimos 10 anos e cooperativas localizadas em perímetros públicos de irrigação. Estas duas condições encerram $82 \%$ dos casos. Em geral, são cooperativas de pequeno e médio porte que operam dominantemente 
no fornecimento de insumos agropecuários e na intermediação de recursos financeiros.

A multiplicidade de cooperativas de idênticos tipo e grau em mesmo espaço geoeconômico enfraquece o cooperativismo, dado que incentiva a competição entre elas, na disputa pelos melhores produtores e clientes. Ademais, há que se considerar inconvenientes tais como:

- problemas de coordenação de ações institucionais de interesse dos produtores;

- manutenção de estruturas administrativas superpostas;

- sustentação de plataformas operacionais com elevado nível de ociosidade, dada a insuficiência de demanda pelos produtores, notadamente em períodos de entressafra.

$27,5 \%$ das cooperativas atuam em base microrregional, entre 4 e 9 municípios. Basicamente, este grupo é constituído por cooperativas que integram produtores de leite ou produtores de grãos. As cooperativas de laticínio, geralmente, trabalham como elemento intermediário entre o pecuarista e a indústria (ou cooperativa central), realizando a recepção do produto em tanques de resfriamento de leite, com capacidade entre 10 mil e 60 mil litros diários.

O último grupo de grande expressão no Nordeste, representando $30 \%$ dos casos, é formado pelas cooperativas mistas que possuem sócios em extensos territórios que, por vezes, superam 50 municipios. A maioria dessas cooperativas foram constituídas até a década de 80 e tiveram como motivação principal a exploração de produtos derivados de algodão ou castanha de caju, bem como o fornecimento de insumos agropecuários modernos. 
5.4 Atividades econômicas desenvolvidas pelas cooperativas agropecuárias nordestinas

As cooperativas nordestinas integrantes da amostra exploram predominantemente os produtos relacionados na Tabela 26 , que coexistem com outras atividades de menor importância reunidas na mesma unidade produtiva.

\begin{tabular}{|c|c|c|}
\hline Tabela 26. & $\begin{array}{l}\text { Atividade } \\
\text { cooperativas } \\
\text { do Nordeste. }\end{array}$ & $\begin{array}{l}\text { principal das } \\
\text { agropecuárias }\end{array}$ \\
\hline \multicolumn{2}{|c|}{ Produto principal } & $\%$ \\
\hline \multicolumn{2}{|c|}{ Leite e derivados } & 27,5 \\
\hline \multicolumn{2}{|c|}{ Arroz } & 20,0 \\
\hline \multicolumn{2}{|l|}{ Algodão } & 15,0 \\
\hline \multicolumn{2}{|l|}{ Frutas } & 12,5 \\
\hline \multicolumn{2}{|l|}{ Castanha } & 5,0 \\
\hline \multicolumn{2}{|l|}{ Soja } & 5,0 \\
\hline \multicolumn{2}{|l|}{ Outros } & 15,0 \\
\hline \multicolumn{2}{|l|}{ Total } & 100,0 \\
\hline
\end{tabular}

Fonte: dados da pesquisa.

Encontram-se poucas cooperativas que exploram atividade única, formadas por produtores especializados. Mais comum são as cooperativas mistas que admitem sócios de vários segmentos da agropecuária, em geral, com baixa capacidade de geração de excedentes econômicos para a comercialização, com a regularidade e qualidade exigidas no mercado.

Cumpre destacar que as atividades relacionadas à pecuária bovina encontram-se presentes em cerca de $70 \%$ das cooperativas. Em geral, as cooperativas possuem engenhos para formulação de ração animal e repassam artigos diversos como vacinas, medicamentos e sais minerais. Há também os casos em que a cooperativa realiza a recepção de leite em tanques de resfriamento, conforme comentado anteriormente. 
Na região Nordeste, a pecuária leiteira é realizada de forma extensiva (criação do gado em pasto), com suplemento alimentar (ração) no período de lactação e em épocas críticas de seca. Esta prática acarreta perda de produtividade, dado o baixo teor nutritivo das pastagens, em especial as nativas. A dispersão geográfica dos produtores relativamente à localização dos pontos de recepção de leite torna problemático o transporte da matéria-prima, causando conflitos no processo de formação do preço. Ademais, o elevado número de pequenos produtores dificulta a inovação tecnológica e a obtenção de economia de escala.

Entre as oito cooperativas da amostra que têm no algodão a principal atividade econômica, apenas uma foi constituída nos anos noventa. As cooperativas que trabalham com fruticultura são, em sua maioria, contemporâneas do Programa de Irrigação do Nordeste (PROINE), ou seja, meados da década de oitenta.

$\mathrm{Na}$ Tabela 27 são listadas as principais fontes de receitas das cooperativas que integram a amostra.

Tabela 27. Composição das receitas das cooperativas agropecuárias do Nordeste.

\begin{tabular}{lrr}
\hline Produto principal & Valor (R\$ mil) & $\%$ \\
\hline Insumos agropecuários & 15.813 & 22,7 \\
Leite & 10.828 & 15,5 \\
Arroz & 9.675 & 13,9 \\
Soja & 7.679 & 11,0 \\
Algodão & 6.910 & 9,9 \\
Supermercado & 4.714 & 6,8 \\
Frutas & 3.552 & 5,1 \\
Posto de combustível & 2.779 & 4,0 \\
Serviços de mecanização & 2.538 & 3,8 \\
Outros & 5.152 & 7,3 \\
\hline Total & 69.640 & 100,0 \\
\hline
\end{tabular}

Fonte: dados da pesquisa. 
A soja vem sendo explorada, há cerca de 20 anos, na região do cerrado do oeste da Bahia e, mais recentemente, no sul do Maranhão e do Piauí. Praticamente toda a soja produzida por cooperados é destinadas às moageiras, que produzem óleo e farelo de soja. O farelo é utilizado na ração para aves e suínos. O óleo de soja refinado, as gorduras hidrogenadas e margarinas destinam-se ao consumo humano.

A cultura do arroz é desenvolvida nos perímetros públicos de irrigação, por cooperativas constituídas até meados da década de oitenta. São organizações que passaram por amplo processo seletivo, sobrevivendo a sucessivas crises.

Nota-se que é expressiva a participação da revenda de produtos agropecuários no faturamento total. De acordo com a atividade da cooperativa, podem ser encontrados até centenas de artigos colocados à disposição dos associados: vacinas, medicamentos, sais minerais, fertilizantes, corretivos de solo, defensivos.

Contudo, cerca de $70 \%$ dos fornecimentos são constituídos de ração para alimentação animal. A ração é formada pela mistura de alimentos capazes de suprir as exigências nutricionais de determinada espécie ou classe de animais.

A comercialização das cooperativas está fortemente concentrada em quatro produtos: arroz e leite representam $29,4 \%$ das vendas em comum; acrescentadas às receitas de soja e algodão, alcança-se 49,4\%. Frutas e produtos hortícolas representam cerca de $5,1 \%$ da comercialização das cooperativas, constituindo, na maioria das vezes, atividade suplementar à produção de grãos. Das cooperativas visitadas, apenas duas dedicam-se predominantemente à exploração comercial de frutas. 
Supermercado e posto de combustível são atividades pouco encontradas nas cooperativas nordestinas. Apenas as grandes cooperativas ainda as mantêm, especialmente as localizadas em áreas distantes de centros urbanos.

\subsection{Serviços prestados pelas cooperativas agropecuárias nordestinas}

Constatou-se a existência de amplo espectro de serviços dispobilizados pelas cooperativas aos associados. $\mathrm{Na}$ Tabela 28 são apresentados os de maior freqüência observada.

Tabela 28. Principais serviços prestados pelas cooperativas agropecuárias do Nordeste.

\begin{tabular}{lc}
\hline Natureza do serviço & $\%$ \\
\hline Repasse de financiamento rural & 82,2 \\
Revenda de insumos agropecuários & 67,5 \\
Comercialização agrícola & 57,5 \\
Mecanização agrícola & 47,5 \\
Armazenamento & 42,5 \\
Beneficiamento de produtos & 35,0 \\
Assistência técnica & 32,5 \\
\hline
\end{tabular}

Fonte: dados da pesquisa.

\subsection{Canais de distribuição utilizados pelas cooperativas agropecuárias nordestinas}

De acordo com Certo \& Peter (1993), canais de distribuição são as cadeias de transmissão da propriedade e/ou da posse do produto. $O$ objetivo primordial do canal de distribuição é viabilizar a organização de uma estrutura que execute com eficiência a função de transferir um bem do produtor ao consumidor. 
Segundo Semenik \& Bamossy (1995), a distribuição pode ser feita direta ou indiretamente. No primeiro caso, o produtor realiza todo o processo de colocação de seus produtos sem a utilização de agentes externos. Em geral, pode-se afirmar que esta conduta limita-se a situações muito particulares em que se tem um mercado geograficamente concentrado ou a presença de especificidades inerentes ao produto. Outra razão que leva à distribuição direta é a inexistência ou inadequação dos canais preexistentes, hipótese em que a empresa passa a exercer internamente as funções ditas de distribuição.

A distribuição direta possui a desvantagem de exigir maiores investimentos em armazenamento e transporte. Porém, permite que se tenha um maior controle de preços e, possivelmente, um fluxo físico mais dinâmico, notadamente de produtos que apresentem relativo grau de diferenciação.

A distribuição indireta é o sistema em que o produtor chega ao consumidor por meio de um ou mais agentes intermediários. Estes podem ou não adquirir a propriedade dos produtos envolvidos.

Geralmente, a ação realizada por canais indiretos é mais lenta e de certa forma onera o preço do produto. De outra parte, especula-se que este sistema enfraquece os controles que o produtor poderia ter sobre os preços e outros atributos de seu produto.

Kotler (1994) propõe a seguinte classificação dos intermediários, quanto à função exercida no processo distribuição:

- agente - é a pessoa que intermedia transações comerciais sem assumir a posse legal dos produtos envolvidos, recebendo remuneração em forma de honorários ou comissão;

- atacadista - é a pessoa que assume a posse e propriedade do produto, revendendo a varejistas e a utilizadores industriais; 
- varejista - é a pessoa que assume a posse e/ou propriedade do produto, revendendo a consumidores finais;

- distribuidor - é uma variação do atacadista que se especializa em desempenhar mais intensivamente determinados serviços relacionados ao produto, tais como assistência técnica, manutenção etc.

Interessante notar que o intermediário pode ser excluído do processo de distribuição, mas suas funções nunca. Portanto, o produtor não pode esquecer-se de que o atacado presta-lhe os seguintes serviços: redução do atendimento a pequenos varejistas, retorno do capital mais rápido, diminui riscos de mercado do produto, orienta na identificação de tendências de mercado, armazenagem, financiamento e simplificação do processo de administração de vendas (Seemenik \& Bamossy, 1995).

Segundo Alves (1997), no Brasil, o comércio varejista de produtos agrícolas é constituído de pequenas e média organizações não concentradas, com alta rotação e grande perecibilidade, que compram poucas quantidades continuamente. Contudo, o comércio atacadista $e$ as grandes redes de supermercado apresentam importância crescente na intermediação de commodities agropecuárias.

De acordo com Kotler (1994), os sistemas de distribuição podem ser intensivos, seletivos ou exclusivos, dependendo das características do produto e da demanda. Os canais intensivos, também chamados gerais ou abertos, apresentam grande amplitude horizontal em razão da utilidade de lugar. Logo, visam a suprir todos os pontos-de-venda possíveis. É recomendável para produtos que possuam grande demanda, intervalos de compra pequenos, baixo custo unitário e reduzida exigência de especialização (demonstração, serviços pós-venda etc.). 
A distribuição seletiva é empregada em produtos que possuem demanda claramente segmentada. Assim, é possível ao produtor cobrir o mercado de forma mais eficiente e com custos inferiores ao sistema de distribuição intensiva (Kotler, 1994).

Já a distribuição exclusiva é empregada quando a empresa deseja manter satisfatório nível de controle sobre os serviços prestados por revendedores. Conforme Seemenik \& Bamossy (1995), esta modalidade de distribuição é recomendada para produtos que envolvam alta especialização para a venda, elevado custo unitário, além de grande esforço de venda e serviços contínuos. É comum nesses casos a exigência de expressivos investimentos do intermediário.

Os canais de distribuição utilizados pelas cooperativas agropecuárias constituintes da amostra, para os principais produtos explorados, estão representados no Quadro 8.

\begin{tabular}{|l|c|c|c|c|c|c|}
\hline Produto & Direta & $\begin{array}{c}\text { Coop. } \\
\text { Central }\end{array}$ & Agroindústria & Atacadista & Varejista & Total \\
\hline Insumos & $100 \%$ & $0 \%$ & $0 \%$ & $0 \%$ & $0 \%$ & $100 \%$ \\
\hline Arroz & $1 \%$ & $81 \%$ & $5 \%$ & $9 \%$ & $4 \%$ & $100 \%$ \\
\hline Algodão & $0 \%$ & $27 \%$ & $62 \%$ & $11 \%$ & $0 \%$ & $100 \%$ \\
\hline Leite & $18 \%$ & $5 \%$ & $4 \%$ & $0 \%$ & $73 \%$ & $100 \%$ \\
\hline Soja & $0 \%$ & $0 \%$ & $2 \%$ & $98 \%$ & $0 \%$ & $100 \%$ \\
\hline Feijão & $0 \%$ & $21 \%$ & $0 \%$ & $79 \%$ & $0 \%$ & $100 \%$ \\
\hline Milho & $46 \%$ & $0 \%$ & $0 \%$ & $54 \%$ & $0 \%$ & $100 \%$ \\
\hline Frutas & $0 \%$ & $0 \%$ & $0 \%$ & $100 \%$ & $0 \%$ & $100 \%$ \\
\hline
\end{tabular}

Quadro 8. Canais de distribuição utilizados pelas cooperativas agropecuárias nordestinas.

Fonte: dados da pesquisa.

A distribuição direta é utilizada pelas cooperativas, por meio da loja de revenda, para fornecimento de insumos agropecuários aos associados. Como visto anteriormente, esta atividade foi observada em $67,5 \%$ das cooperativas 
examinadas e representa a maior fonte de receitas. Logo, as cooperativas atuam na condição de varejista e distribuidor de insumos agrícolas a seus associados, realizando ainda vendas a terceiros, em caráter suplementar.

As cooperativas centrais possuem maior participação na comercialização de arroz, algodão e feijão recebidos de suas singulares. A soja é quase integralmente comercializada pelas cooperativas junto a atacadistas que atuam por meio de representantes locais de grandes empresas de comercialização, tais como Cargill, Ceval e Eximcoop.

O varejo é alcançado pelas cooperativas, de forma expressiva, apenas no caso do leite, em que $73 \%$ do produto é distribuído em supermercado, mercearias e padarias.

Quanto ao destino da produção, com exceção da soja, os demais produtos são vendidos preponderantemente nos mercados local e estadual. Segundo informações prestadas por dirigentes, cerca $40 \%$ da soja após aquisição por atacadistas destina-se à industria de esmagamento, para produção de óleo e farelo, e o restante é exportado in natura. Algodão e arroz têm mercado regional (Quadro 9).

\begin{tabular}{|l|c|c|c|c|c|c|}
\hline Produto & Local & Estadual & Regional & Nacional & Internacional & Total \\
\hline Insumos & $100 \%$ & $0 \%$ & $0 \%$ & $0 \%$ & $0 \%$ & $100 \%$ \\
\hline Arroz & $24 \%$ & $29 \%$ & $47 \%$ & $0 \%$ & $0 \%$ & $100 \%$ \\
\hline Algodão & $23 \%$ & $12 \%$ & $57 \%$ & $8 \%$ & $0 \%$ & $100 \%$ \\
\hline Leite & $86 \%$ & $14 \%$ & $0 \%$ & $0 \%$ & $0 \%$ & $100 \%$ \\
\hline Soja & $0 \%$ & $0 \%$ & $10 \%$ & $90 \%$ & $0 \%$ & $100 \%$ \\
\hline Feijão & $73 \%$ & $27 \%$ & $0 \%$ & $0 \%$ & $0 \%$ & $100 \%$ \\
\hline Milho & $78 \%$ & $17 \%$ & $5 \%$ & $0 \%$ & $0 \%$ & $100 \%$ \\
\hline Frutas & $77 \%$ & $2 \%$ & $0 \%$ & $21 \%$ & $0 \%$ & $100 \%$ \\
\hline
\end{tabular}

Quadro 9. Destino da produção das cooperativas agropecuárias nordestinas.

Fonte: dados da pesquisa. 


\subsection{Recursos humanos nas cooperativas agropecuárias nordestinas}

As cooperativas da amostra congregam 25.351 sócios, dos quais $64,2 \%$ são considerados ativos, segundo resposta oferecida pelos entrevistados. Aqui, cabe melhor qualificação desse último indicador que se apresenta aparentemente muito acima da média nacional, estimada por Lopes et al. (1997).

Por nem sempre reunir condições de realizar a comercialização ou o beneficiamento da produção do associado, as cooperativas não adotam regras formais para controle do nível de atividade do produtor. Possivelmente, essa conduta resulte do fato de que parcela expressiva dos agricultores filiados desenvolve, não raro, atividades econômicas estranhas ao negócio principal da cooperativa, denotando baixo nível de integração horizontal e vertical.

Na Tabela 29 são apresentados os principais critérios, e respectiva freqüência, adotados pelas cooperativas para classificar o sócio como atuante ou não atuante.

Tabela 29. Critérios adotados pelas cooperativas agropecuárias do Nordeste para classificação de sócios ativos.

\begin{tabular}{lc}
\hline Principais parâmetros utilizados & $\%$ \\
\hline $\begin{array}{l}\text { Realização de quaisquer transações econômicas nos últimos doze meses com a } \\
\text { cooperativa }\end{array}$ & 45,0 \\
$\begin{array}{l}\text { Realização de transações econômicas correspondentes a pelo menos } 30 \% \text { do } \\
\text { volume de negócios explorados pelo associado }\end{array}$ & 7,5 \\
$\begin{array}{l}\text { Realização de transações econômicas correspondentes a pelo menos } 60 \% \text { do } \\
\text { volume de negócios explorados pelo associado }\end{array}$ & 10,0 \\
Não existem critérios explícitos & 37,5 \\
\hline
\end{tabular}

Fonte: dados da pesquisa.

Nota-se que em $82,5 \%$ dos casos há completa ausência de parâmetros ou critérios muito vagos para enquadrar o associado como ativo. É também 
pouco freqüente cooperativas que consideram as operações decorrentes do ato cooperativo para fins de classificação do sócio como atuante.

Assim sendo, uma esporádica aquisição de insumos na revenda da cooperativa ou a existência de débitos pendentes originados de empréstimo (conta corrente) ou financiamento (repasse) é suficiente para que se atribua ao sócio a condição de atuante.

Conforme apresentado na Tabela 30 , as cooperativas da amostra possuem média de 634 sócios e metade delas têm menos de 383 sócios. Apenas três cooperativas da amostra apresentaram quadro social superior a 2.000 produtores rurais.

Tabela 30. Dimensão do quadro de associados das cooperativas agropecuárias do Nordeste.

\begin{tabular}{cccccccc}
\hline Ano & Média & Mediana & $\begin{array}{c}\text { Desvio } \\
\text { padrão }\end{array}$ & Mínimo & Máximo & $\begin{array}{c}\text { Coeficiente de } \\
\text { variação }\end{array}$ & $\begin{array}{c}\text { Número de } \\
\text { observações }\end{array}$ \\
\hline 1998 & 634 & 383 & 821 & 36 & 4.448 & 1,30 & 40 \\
1997 & 642 & 412 & 838 & 36 & 4.420 & 1,31 & 38 \\
1996 & 682 & 432 & 836 & 43 & 4.328 & 1,23 & 35 \\
\hline
\end{tabular}

Fonte: dados da pesquisa.

O número de associados nas cooperativas do Nordeste é um pouco inferior a 50\% da média estimada para o Brasil por Lopes et al. (1997). Nota-se também que, nos três anos considerados, o número médio de associados nas cooperativas do Nordeste caiu $7 \%$.

Uma possível explicação para este fenômeno talvez seja o fato de o Banco do Nordeste ter limitado, em 1995, o apoio financeiro à cooperativa iniciante para atendimento das necessidades de crédito de 100 associados, podendo em fase posterior examinar pleitos complementares até o limite de 600 associados assistidos. 
Nesse sentido, é interessante notar que das catorze 14 cooperativas integrantes da amostra que foram fundadas após outubro de 1988, treze possuem menos de 600 associados, situando-se a média destas cooperativas em torno de 153 sócios.

Considerando que a constituição de cooperativas na região Nordeste sempre esteve muito relacionada às condições operacionais de programas de governo, o recrutamento e seleção de associados, por vezes feitos apressadamente, não esgota o exame das potencialidades de relacionamento duradouro entre o produtor rural e a cooperativa.

Os dados da Tabela 31 revelam que nas cooperativas da amostra há predomínio da regra doutrinária de portas abertas, ficando em plano secundário a adoção de critérios de natureza empresarial.

Tabela 31. Critérios adotados pelas cooperativas agropecuárias do Nordeste para recrutamento de sócios

\begin{tabular}{lc}
\hline Principais critérios utilizados & $\%$ \\
\hline Livre entrada e saída de associados & 65,0 \\
Localização geográfica do produtor & 42,5 \\
Atividades produtivas exploradas pelo produtor & 27,5 \\
$\begin{array}{l}\text { Compatibilidade entre as atividades do agricultor e o foco principal de } \\
\text { negócios explorados pela cooperativa }\end{array}$ & 22,5 \\
$\begin{array}{l}\text { Tamanho da exploração agropecuária } \\
\text { Capacidade do produtor rural na mobilização de capitais (próprios ou } \\
\text { financiados), para futuros investimentos }\end{array}$ & 12,5 \\
Receptividade do produtor rural à inovação tecnológica & 7,5 \\
\hline
\end{tabular}

Fonte: dados da pesquisa.

$\mathrm{Na}$ Tabela 32 é apresentada a freqüência de participação dos associados das cooperativas da amostra nas assembléias gerais no ano de 1998. Em $80 \%$ dos casos, menos de $50 \%$ dos associados participam da 
assembléia geral. Em apenas $10 \%$ das cooperativas o índice de participação é superior a $70 \%$ dos associados.

\begin{tabular}{lc}
$\begin{array}{l}\text { Tabela 32. Presença de associados de cooperativas } \\
\text { agropecuárias do Nordeste em assembléia } \\
\text { geral. }\end{array}$ \\
\hline Nível de participação & $\%$ \\
\hline Até $20 \%$ dos associados & $57,5 \%$ \\
Entre $20 \%$ e $50 \%$ dos associados & $22,5 \%$ \\
Entre $50 \%$ e $70 \%$ dos associados & $12,5 \%$ \\
Entre $70 \%$ e $90 \%$ dos associados & $7,5 \%$ \\
Mais de $90 \%$ dos associados & $2,5 \%$ \\
\hline
\end{tabular}

Fonte: dados da pesquisa.

O desinteresse do produtor em relação à cooperativa pode ser explicado por diversos motivos. Contudo, a causa predominante, provavelmente, reside na baixa participação de capitais próprios nos fundos utilizados para financiar os ativos operacionais dos empreendimentos coletivos.

Os dados da Tabela 33 mostram que mais de um terço das cooperativas não dispõe de sistema de informação e mais de três quartos delas não fornecem informações de forma continuada aos associados.

Tabela 33. Recorrência das informações disponibilizada aos sócios.

\begin{tabular}{lc}
\hline Freqüência das informações & $\%$ \\
\hline Nunca & 35,0 \\
Ocasionalmente & 42,5 \\
Regularmente & 20,0 \\
Freqüentemente & 2,5 \\
Sempre & 0,0 \\
\hline
\end{tabular}

Fonte: dados da pesquisa.

Também foi notado um grande distanciamento da direção das cooperativas relativamente aos associados, em especial nas corporações de maior porte. Como conseqüência do baixo nivel de envolvimento entre 
cooperado e cooperativa, esta praticamente não exerce nenhum controle sobre o sistema de produção daquele.

Segundo os dados da Tabela 34, apenas um oitavo das cooperativas examinadas acompanha o nível de produção de seu associado. Esta situação deriva, em grande parte, da política interna de preço, tema que será abordado mais adiante.

Tabela 34. Sistema de monitoramento dos associados das cooperativas agropecuárias do Nordeste.

\begin{tabular}{lc}
\hline Exercício de controle das atividades dos produtores filiados & $\%$ \\
\hline $\begin{array}{lc}\text { Existe contrato específico (formal ou informal) que prevê o volume de } \\
\text { transações entre cooperativa e cooperado }\end{array}$ & 12,5 \\
A cooperativa não determina o volume a ser entregue & 25,0 \\
Não há controles formalizados & 62,5 \\
\hline
\end{tabular}

Fonte: dados da pesquisa.

Fruto da fraca relação contratual entre associado e cooperativa, a aplicação de sanções aos sócios que desviam a produção é evento raro, conforme apresentado na Tabela 35.

Tabela 35. Freqüência de aplicação de sanção a associados nas cooperativas agropecuárias do Nordeste.

\begin{tabular}{lccccc}
\hline Sanção & Nunca & Ocasional & Regular & Freqüente & Sempre \\
\hline Advertência & $67,5 \%$ & $7,5 \%$ & $12,5 \%$ & $7,5 \%$ & $5,0 \%$ \\
Multa & $95,0 \%$ & $2,5 \%$ & $2,5 \%$ & $0,0 \%$ & $0.0 \%$ \\
Suspensão & $87,5 \%$ & $5,0 \%$ & $5,0 \%$ & $2,5 \%$ & $0,0 \%$ \\
Exclusão & $75,0 \%$ & $17,5 \%$ & $7,5 \%$ & $0,0 \%$ & $0,0 \%$ \\
Nenhuma & $32,5 \%$ & $0,0 \%$ & $0,0 \%$ & $7,5 \%$ & $60,0 \%$ \\
\hline
\end{tabular}

Fonte: dados da pesquisa.

As cooperativas da amostra são dirigidas por diretoria ou conselho de administração eleito por assembléia de associados. Em nenhuma delas se verificou a presença de gestão exclusivamente profissional. 
O conjunto das cooperativas pesquisadas possui 227 diretores e conselheiros. A média situa-se em torno de seis dirigentes por organização. Deste total, $13,7 \%$ têm nível superior e $27,7 \%$ cursaram até o ensino médio. A maioria, $58,6 \%$, possui formação inferior ao ensino fundamental completo, conforme apresentado no Quadro 10.

\begin{tabular}{|l|r|c|c|c|}
\hline \multirow{2}{*}{$\begin{array}{c}\text { Equipe de trabalho } \\
\text { Cargo/Função }\end{array}$} & \multirow{2}{*}{ Total } & \multicolumn{3}{|c|}{ Quantidade } \\
\cline { 3 - 5 } & & Nível de escolaridade \\
\cline { 3 - 5 } & 227 & 133 & 63 & 31 \\
\hline Diretoria/Conselho & 37 & 0 & 29 & 8 \\
Gerência operacional & 10 & 0 & 5 & 5 \\
Gerência administrativa & 35 & 0 & 27 & 8 \\
Contador & 33 & 0 & 33 & 0 \\
Técnico agrícola & 25 & 0 & 0 & 25 \\
Agrônomo/Veterinário & 196 & 65 & 110 & 21 \\
Pessoal administrativo & 722 & 435 & 280 & 7 \\
Pessoal operacional & 1.285 & 633 & 547 & 105 \\
\hline Total geral & &
\end{tabular}

Quadro 10. Distribuição funcional dos recursos humanos das cooperativas agropecuárias do Nordeste por nível de escolaridade.

Fonte: dados da pesquisa.

Lopes \& Lopes (1997) estimam que os dirigentes de cooperativas agropecuárias brasileiras possuem escolaridade superior, média e fundamental, respectivamente, nas seguintes proporções: $41 \%, 39 \%$ e $19 \%$, denotando que o cooperativismo agropecuário nordestino dispõe de recursos humanos menos preparados para o exercício profissional.

A presença de gerência operacional contratada é relativamente pequena nas cooperativas nordestinas. No total, foram registrados apenas 47 profissionais que exercem cargo de direção em nível operacional em 24 cooperativas. Cabe destacar que 16 desses profissionais pertencem a uma cooperativa de grande porte. As demais cooperativas que possuem gerentes operacionais contratados têm entre um e três profissionais. Portanto, é 
expressiva, cerca de $40 \%$, a quantidade de cooperativas que não mantêm profissionais externos em cargo de gerência.

Dos profissionais contratados para cargo de gerência, $27,7 \%$ possuem curso superior e $72,3 \%$ têm nível secundário. Cerca de $80 \%$ desses profissionais atua em atividades administrativas e operacionais da cooperativa, não se envolvendo com a representação institucional da organização. Em apenas nove cooperativas, a gerência apresenta algum grau de especialização, sendo delegadas ao gerente atividades relacionadas a questões estratégicas da empresa.

As cooperativas da amostra empregam diretamente 1.058 funcionários, mantendo uma média de 26 funcionários por cooperativa e uma relação de 23 associados para cada empregado. Apenas $6,8 \%$ do quadro funcional têm formação de nível superior; $42,8 \%$ têm nível médio e $50,4 \%$ escolaridade inferior ao ensino fundamental completo. Esses resultados aproximam-se das estimativas feitas por Lopes \& Lopes (1997) para o Brasil, respectivamente, $11 \%, 33 \%$ e $56 \%$, revelando que o Nordeste possui maior proporção de empregados com nível de escolaridade maior que o ensino médio, embora possua menor participação relativa de profissionais com curso superior.

Dos 74 profissionais de nível superior, 20,3\% exercem funções de gerência operacional, 33,8\% atuam na área agronômica, $28,4 \%$ trabalham em atividades administrativas internas e os $17,5 \%$ restantes estão alocados em outras atividades operacionais. Os 484 profissionais de nível secundário estão alocados preponderantemente (61\% dos casos) em atividades operacionais. $22 \%$ deles estão na área administrativa e apenas $6,8 \%$ desenvolvem atividades de assistência técnica voltada para o produtor rural.

As atividades de controladoria nas cooperativas estão confiadas a escritórios de contabilidade, mantendo-se em média apenas um funcionário interno dedicado a tais serviços. No grupo de cooperativas estudado, 
encontrou-se 35 contadores profissionais contratados, sendo oito de nível superior.

A prestação de serviço de orientação técnica ao produtor rural parece ser uma atividade de pouca importância atualmente, visto que poucos profissionais da área de ciências agrárias, incluídos os técnicos agrícolas, compõem o quadro funcional das cooperativas, bem como devido ao fato de que praticamente tal função não se encontra entre os serviços terceirizados.

Das 40 cooperativas visitadas, 17 disponibilizam serviços de assistência técnica a seus associados. Destas, 14 mantêm serviço próprio e três empregam exclusivamente mão-de-obra terceirizada. Entre as cooperativas que possuem serviço próprio de assistência técnica, metade delas o complementa com serviços de terceiros, verificando-se apenas cinco cooperativas que trabalham exclusivamente com quadro próprio.

As cooperativas que prestam serviço de orientação técnica possuem 29 profissionais de ciências agrárias, ou seja, até dois técnicos por organização. Considerando que o quadro social destas cooperativas é de 7.499 cooperados, tem-se uma relação de 259 produtores rurais associados para cada técnico.

\subsection{Desempenho financeiro das cooperativas agropecuárias nordestinas}

As cooperativas da amostra possuem ativos totais médio da ordem de $R \$ 4,1$ milhões, dos quais $R \$ 2,3$ milhões representam operações de repasse a associados, realizáveis em longo prazo, conforme disposto na Tabela 36, na qual são apresentadas estatísticas descritivas dos principais grupos das demonstrações financeiras das cooperativas, relativas ao exercício de 1998. 
Tabela 36. Indicadores de desempenho financeiro das cooperativas agropecuárias do Nordeste.

Valores em $\mathrm{R} \$ 1.000$

\begin{tabular}{lrrrrrr}
\hline Grupo Contábil & Média & Mediana & $\begin{array}{c}\text { Desvio } \\
\text { padrão }\end{array}$ & Mínimo & Máximo & $\begin{array}{r}\text { Coeficiente } \\
\text { de variação }\end{array}$ \\
\hline Ativo total & 4.142 & 3.109 & 4.353 & 37 & 23.468 & 1,05 \\
Ativo circulante & 960 & 372 & 1572 & 0 & 9.369 & 1,05 \\
Realizável LP & 2.278 & 1.945 & 1.909 & 0 & 9.960 & 0,84 \\
Cart. Repasse & 1.648 & 1.396 & 1.455 & 0 & 5.524 & 0,88 \\
Ativo permanente & 903 & 389 & 1.878 & 3 & 11.170 & 2,08 \\
Imobilizado & 845 & 362 & 1.717 & 3 & 9.999 & 2,03 \\
Passivo circulante & 705 & 270 & 1.146 & 1 & 6.005 & 1,63 \\
P.exigível LP & 2.355 & 2.008 & 1.994 & 0 & 10.957 & 0,84 \\
Financ. banc. LP & 2.324 & 2.007 & 1.988 & 0 & 10.956 & 0,86 \\
Patrim. Liquido & 1.082 & 516 & 1986 & -92 & 9.423 & 1,84 \\
Capital social & 600 & 239 & 1.312 & 4 & 8.079 & 2,19 \\
Fund. Indivisíveis & 482 & 277 & 1.037 & 0 & 6.494 & 2,15 \\
Faturamento & 1.741 & 464 & 4.076 & 0 & 22.977 & 2,34 \\
Sobras líquidas & -33 & -18 & 143 & -318 & 565 & 4,33 \\
Sobras distribuídas & 6 & 0 & 24 & 0 & 149 & 4,00 \\
\hline
\end{tabular}

Fonte: dados da pesquisa.

Fato que chama a atenção é a expressividade da carteira de financiamento de longo prazo das cooperativas, que representa quase $40 \%$ dos ativos totais.

O faturamento líquido das cooperativas da amostra perfaz $R \$ 69,6$ milhões, resultando em rendimento médio de $R \$ 1,7$ milhão por organização. $58,3 \%$ deste valor são constituídos por operações relativas à comercialização de produtos agropecuários e $22,4 \%$ decorrem de operações de revenda de insumos agrícolas. $O$ restante refere-se a diversas atividades de prestação de serviços (mecanização agrícola, assistência técnica, eletrificação rural etc.), exploração de supermercado e postos de combustíveis. 
Este desempenho apresenta-se bastante modesto ao considerar-se 0 rendimento per capita de apenas $R \$ 2,8$ mil, por sócio, ou de $R \$ 4,4$ mil, por sócio ativo. Em cerca de $43 \%$ das cooperativas, o faturamento por sócio não ultrapassa $\mathrm{R} \$ 1,0$ mil. Esta situação só não é mais grave porque o produtor rural filiado, geralmente, não tem na cooperativa sua fonte exclusiva de receita.

O nível de atividade econômica nas cooperativas agropecuárias nordestinas examinadas é, igualmente, pequeno quando comparado ao ativo total, dado que seu giro operacional situa-se em torno de $42 \%$. Esse desempenho indica a existência de uma possível ociosidade de ativos operacionais, que poderá comprometer a rentabilidade dos projetos financiados e, por conseqüência, a liquidez das próprias cooperativas.

O ativo imobilizado das cooperativas examinadas situa-se, em média, próximo de $\mathrm{R} \$ 845 \mathrm{mil}$, correspondentes a $20,4 \%$ do ativo total. É modesta a participação das cooperativas no capital de outras organizações congêneres ou empresas de capital. Os parcos recursos registrados como investimento societário referem-se, preponderantemente, à capitalização compulsória junto ao extinto Banco Nacional de Crédito Cooperativo (BNCC) e às companhias de energia elétrica.

O nível de endividamento das cooperativas da amostra é consideraveimente elevado. A participação de capitais de terceiros atinge a proporção de $73 \%$ dos fundos totais utilizados pelas cooperativas. É oportuno assinalar que mais de dois terços das dívidas das cooperativas representam operações de repasse a associados. Portanto, excluídas as obrigações dos sócios, o endividamento à própria cooperativa recua para $34 \%$ do passivo total.

Quanto à liquidez, a situação geral das cooperativas investigadas não se apresenta satisfatória, numa perspectiva de médio e longo prazo, embora a posição atual pareça razoável. 
A liquidez corrente média situa-se em torno de 1,32: 1,00. A liquidez geral média, que envolve os fundos e aplicações de longo prazo, situa-se em torno de 1,06: 1,00. Contudo, cumpre destacar que cerca de $30 \%$ das cooperativas já estão com sua capacidade de pagamento comprometida, não reunindo condições de honrar suas obrigações imediatas.

Tendo em vista o baixo nível de atividade econômica nas cooperativas nordestinas sob exame, prevê-se um agravamento da liquidez à medida que se aproximem as datas de reembolso dos financiamentos contraídos. Esta situação se complica em razão de o estoque da dívida vir sendo corrigido, nos últimos anos, a taxas muito superiores aos índices de preços recebidos pelo produtor.

\subsection{Políticas de preço interno adotadas pelas cooperativas agropecuárias nordestinas}

A decomposição dos dados do Censo Agropecuário 1995-96 do IBGE revelou que as cooperativas agropecuárias nordestinas absorvem apenas $10,5 \%$ do valor da produção vegetal de seus associados. Entre os principais produtos, a participação das cooperativas na comercialização é a seguinte: arroz $(26,6 \%)$, feijão $(9,0 \%)$, milho $(5,2 \%)$, soja $(50,2 \%)$ e cana-de-açúcar $(1,8 \%)$.

Considerando que $85 \%$ do volume comercializado pelas cooperativas da amostra examinada provêm das unidades produtivas dos próprios associados, infere-se que essas organizações vêm mantendo altas taxas de ociosidade de ativos operacionais, possivelmente superiores às reveladas pelos dirigentes entrevistados.

$\mathrm{Na}$ Tabela 37 são apresentados os níveis médios de utilização da capacidade instalada das unidades de beneficiamento de produtos selecionados. 
Tabela 37. Nível de utilização da capacidade instalada das cooperativas agropecuárias do Nordeste.

\begin{tabular}{lr}
\hline Agroindústria & $\%$ \\
\hline Fábrica de ração animal & 57,8 \\
Unidade de resfriamento de leite & 37,2 \\
Unidade de industrialização de leite & 52,3 \\
Beneficiamento de algodão & 5,4 \\
Extração de óleos brutos & 38,1 \\
Beneficiamento de castanha de caju & 17,0 \\
Beneficiamento de arroz & 56,2 \\
Beneficiamento de frutas (sucos) & 22,6 \\
Beneficiamento de frutas (doces) & 46,3 \\
Beneficiamento de sisal & 60,5 \\
\hline
\end{tabular}

Fonte: dados da pesquisa.

Tendo em vista que o nível de atividade econômica desenvolvido pelas cooperativas agropecuárias do Nordeste encontra-se aquém da capacidade instalada, procurou-se investigar as razões que levam os sócios de cooperativas a operar com empresas concorrentes. Esta conduta, possivelmente, pode ser explicada pelo exame da política interna de preço da cooperativa.

A maioria das organizações pesquisadas, cerca de $92,5 \%$, revelou que o preço pago ao produtor associado pelo produto entregue à cooperativa é semelhante às cotações de mercado. Pelo menos $80 \%$ das cooperativas não adotam a estratégia de diferenciação dos preços pagos aos produtores, conforme apresentado na Tabela 38. 
Tabela 38. Política interna de preços revelada pelas cooperativas agropecuárias do Nordeste.

\begin{tabular}{lc}
\hline Fator considerado & $\%$ \\
\hline Preço diferenciado por qualidade do produto entregue & 20,0 \\
Preço diferenciado por quantidade de produto entregue & 7,5 \\
Preço diferenciado por regularidade na entrega de produto & 2,5 \\
Desconto diferenciado por volume de insumos adquiridos & 20,0 \\
Desconto diferenciado por regularidade na aquisição de insumos & 17,5 \\
Discriminação entre associado e não-associado & 70,0 \\
Recebimento da produção por preço acima da cotação de mercado & 7,5 \\
Oferta de insumos por preço abaixo da cotação de mercado & 47,5 \\
Distribuição de sobras & 22,5 \\
Reinvestimento de sobra. & 42,5 \\
\hline
\end{tabular}

Fonte: dados da pesquisa.

Das cooperativas visitadas, apenas sete possuem política de pagamento de preço básico com ágio ou deságio em função da qualidade do produto. Destas, três também adotam o pagamento diferenciado em razão do volume negociado e apenas uma premia o associado pela regularidade no fornecimento de matérias-primas (sistema de cotas de entrega de leite, no período de safra).

Argumentam os dirigentes das cooperativas que suas organizações possuem escassos recursos para custeio de atividades de giro, fato que limita a possibilidade de antecipação de créditos ao produtor durante a comercialização agrícola. Por sua vez, os associados não confiam às cooperativas a simples entrega da produção, para posterior recebimento dos recursos, em virtude de outros agentes intermediários proporcionarem preços semelhantes e pagarem a vista. De certo, as vantagens competitivas desses agentes de comércio decorrem de atos de elisão fiscal, em geral, não praticados pelas cooperativas. 
No que diz respeito às compras em comuns (material de revenda), as cooperativas são mais efetivas que na comercialização agrícola. Em 22 cooperativas ( $55 \%$ do total) há tratamento diferenciado do associado em relação aos produtores rurais não-cooperados.

Aos associados, 17 cooperativas ( $42,5 \%$ do total) fornecem insumos agropecuários a preços inferiores aos encontrados no mercado. Os descontos variam de $1 \%$ a $8 \%$, dependendo do produto e do prazo de pagamento.

Verificou-se ainda a prática de preços diferenciados em função do volume transacionado em oito cooperativas. A diferenciação por regularidade possui freqüência pouco expressiva na atividade de revenda de insumos agropecuários.

Em que pese o tratamento diferenciado dispensado ao sócio por algumas cooperativas, é na atividade de revenda de insumos agropecuários que se verifica o maior volume de operações com terceiros. Nos municípios do interior do Nordeste freqüentemente as cooperativas são as únicas fornecedoras de insumos. As transações com não-associados são realizadas quase sempre a vista e com satisfatória margem de rentabilidade. Assim, justificam os dirigentes que as unidades de revenda dão estabilidade financeira à cooperativa, gerando recursos para a manutenção de outras atividades de interesse dos cooperados.

Isto posto, constata-se que as vantagens dos associados das cooperativas da amostra, especialmente na comercialização, são pouco atraentes em curto prazo. Desta forma, os sócios só trabalharão com as cooperativas se houver perspectivas visíveis de distribuição de sobras no final do exercício.

Ocorre que, entre as cooperativas pesquisadas, apenas sete declararam possuir política de distribuição de sobras. Nos últimos três anos, só 
cinco cooperativas colocaram à disposição da assembléia geral sobras de inexpressivo valor, conforme mostrado na Tabela 36.

Assim sendo, a inadequação da política de remuneração do trabalho dos associados provoca o afastamento deles da cooperativa.

Ante o aumento da concorrência e a retração das políticas compensatórias voltadas para o setor agropecuário, procurou-se examinar quais medidas de ajustamento à nova realidade foram implementadas no último triênio. A Tabela 39 contém a freqüência observada nas cooperativas integrantes da amostra.

Tabela 39. Ações realizadas, nos últimos três anos para melhorar o desempenho dos negócios das cooperativas agropecuárias do Nordeste.

\begin{tabular}{lr}
\hline Tipo de reforma & $\%$ \\
\hline Terceirização de serviços & 52,5 \\
Ampliação e melhoria dos serviços de assistência técnica & 40,0 \\
Controle de custos por tipo de serviço prestado & 40,0 \\
Melhoria na qualidade dos produtos & 40,0 \\
Redução de custo de produção & 40,0 \\
Profissionalização da gestão & 35,0 \\
Melhoria da fidelidade dos associados em relação à cooperativa & 32,5 \\
Desinvestimento de ativos ociosos & 27,5 \\
Ênfase na utilização da capacidade produtiva & 25,0 \\
Formação de alianças e parcerias & 22,5 \\
Direcionamento dos recursos para atividades de maior valor adicionado & 22,5 \\
Aumento da linha de produtos & 17,5 \\
Redução da linha de produtos & 12,5 \\
Diferenciação de produtos & 7,5 \\
Reconversão produtiva & 7,5 \\
Fusão/incorporação & 2,5 \\
\hline
\end{tabular}

Fonte: dados da pesquisa.

Estes números revelam grande resistência da maioria das cooperativas em adotar políticas que visem à reorientação de suas atividades econômicas. 
Contudo, nota-se certa sensibilização de algumas cooperativas relativamente à necessidade de reavaliação de seu modelo organizacional.

Ultimamente, as cooperativas têm reduzido sua participação em atividades de apoio, mediante a realização de contratos de prestação de serviços com terceiras empresas. A participação de empresas terceirizadas concentra-se nas atividades de assistência técnica ao produtor rural, contabilidade e serviço de transporte de materiais e produtos agrícolas.

A estratégia de crescimento por meio de fusão e incorporação é alternativa que encontra resistência nas cooperativas. Apenas uma, entre as $\mathbf{4 0}$ cooperativas analisadas, iniciou estudos com vistas a examinar a viabilidade de reunir-se com outra cooperativa.

Os contratos de parceria ou aliança para a exploração de atividades compartilhadas também ocorrem com escassa freqüência. Contudo, foram identificadas algumas práticas interessantes:

- cinco cooperativas mantêm acordo de cooperação com universidades e institutos de pesquisa com o objetivo de melhorar 0 padrão tecnológico empregado pelo produtor associado, mediante 0 desenvolvimento de técnicas apropriadas à pequena propriedade rural;

- duas cooperativas do segmento de castanha atuam conjuntamente no processamento do produto. $\mathrm{O}$ objetivo da parceria é manter a regularidade do fluxo produtivo de forma a preservar contrato de fornecimento com um distribuidor do produto;

- determinada cooperativa central que industrializa arroz originado dos associados de três cooperativas singulares firmou contrato com 
uma empresa de comercialização para que esta ficasse responsável pelas atividades afetas ao segmento comercial;

- em sete cooperativas verificou-se que a assistência ao produtor rural é feita por intermédio de empresas contratadas.

\subsection{Apresentação do caso Camapla}

A Cooperativa Agrícola Mista de Angical do Piauí Ltda. (Camapla), fundada há três décadas, possui 537 associados e atua em três ramos de atividades da economia rural e agroindustrial, conforme apresentado no Quadro 11.

\begin{tabular}{|l|c|c|c|}
\hline \multirow{2}{*}{ Atividade econômica } & \multicolumn{3}{|c|}{ Número de produtores } \\
\cline { 2 - 4 } & Total do município (A) & Associados (B) & B/A \\
\hline Agricultura & 7.200 & 317 & $4,4 \%$ \\
\hline Pecuária leiteira & 500 & 100 & $20,0 \%$ \\
\hline Avicultura & 280 & 120 & $42,9 \%$ \\
\hline
\end{tabular}

Quadro 11. Participação relativa da Camapla na agropecuária microrregional.

Fonte: Camapla.

A Cooperativa é gerida por um conselho de administração composto por 11 associados eleitos em assembléia geral para mandato de três anos. As principais atribuições do colegiado são: representar a Cooperativa administrativa e juridicamente; adquirir, alienar e onerar bens móveis e imóveis; contrair obrigações; constituir mandatários; instituir e fazer cumprir os atos autorizados pela assembléia geral. Os atos de gerência são monitorados por um conselho fiscal composto por três membros eleitos para mandato de um ano.

A Camapla evoluiu acompanhando o rastro de programas governamentais. Os principais instrumentos de fomento à modernização de 
práticas agrícolas foram o crédito agrícola e os favores fiscais. Assim, a Camapla pôde construir expressiva plataforma operacional praticamente sem a participação de capital próprio dos associados.

A história da Camapla começa em 1957, quando um grupo de 67 pequenos produtores fundaram a Cooperativa com o objetivo de suprir a carência de oferta de insumos agropecuários no município de Angical do Piauí, estado do Piaú.

Nos anos setenta, a Camapla estendeu sua área de atuação para cinco municípios circunvizinhos, mediante a abertura de postos de revenda de insumos agropecuários para atendimento de 320 produtores associados. Nos anos oitenta, a Camapla já atuava em dez municípios e reunia cerca de 2.000 produtores rurais. Nesse período, foram incorporadas aos propósitos da organização atividades relacionadas à comercialização de produtos primários. No início de 1998, a Camapla tinha quase 3.000 associados, dos quais menos de $20 \%$ eram ativos.

Em meados de 1998, iniciou-se amplo processo de reordenamento do quadro social, oportunidade em que foram eliminados os sócios inativos, de acordo com as normas estatutárias e atendidas as disposições legais. Após o recadastramento, restaram 537 produtores, domiciliados em treze municipios, que se dispuseram a construir novas bases contratuais de relacionamento com a Cooperativa.

É oportuno destacar que, embora os pequenos produtores constituam cerca de $90 \%$ do quadro social, são os médios produtores que efetivamente movimentam maiores volumes de produto na Cooperativa. É esse grupo de produtores que utiliza, com maior freqüência, os serviços oferecidos pela fábrica de ração e pela indústria de laticínios. Também não é ocioso afirmar que aludidos produtores formam importante facção que controla as diretrizes organizacionais e as ações operacionais da Camapla. 
317 produtores filiados à Camapla exploram as culturas de milho e arroz, obtendo produtividade de, respectivamente, $2.000 \mathrm{~kg} / \mathrm{ha}$. e $1.800 \mathrm{~kg} / \mathrm{ha}$., juntamente com a pecuária bovina de corte.

150 associados são avicultores de corte e 30 produtores são avicultores. Estas atividades, por exigirem maior especialização, são exploradas isoladamente das demais. Atualmente, os produtores da Camapla comercializam o frango vivo. Esta condição deixa os produtores com pouca margem de manobra, dada a inflexibilidade das datas de entrega, em razão de não ser economicamente viável manter alojadas aves com mais de 43 dias de idade.

A pecuária leiteira é desenvolvida por 40 associados que possuem rebanho médio composto de cinco matrizes em lactação, com produtividade de oito litros diários. O sistema de criação é semi-extensivo, em que o gado é mantido no pasto e oferecida suplementação alimentar.

Nos últimos anos, a Camapla concentrou seus esforços no suprimento de insumos agropecuários, notadamente a fabricação de ração animal. Desde 1995, a Cooperativa deixou de fazer a comercialização de arroz, em virtude do declínio da atividade dessa lavoura na microrregião. Então, o único elo de relacionamento dos produtores de arroz com a Cooperativa limitou-se às transações com a revenda de insumos e, eventualmente, à prestação de serviços de mecanização agrícola e transporte de produtos primários.

A fábrica de ração da Cooperativa tem capacidade para produzir 1.050 toneladas/mês, em turno de oito horas, e estrutura de armazenagem de 66 toneladas. Segundo registros da Cooperativa, o máximo que se produziu foi 900 toneladas, correspondentes a $85 \%$ da capacidade instalada. Durante o ano de 1998, a quantidade mensal de ração produzida variou entre 250 toneladas e 615 toneladas, revelando ociosidade de $63,3 \%$. 
Com essa performance operacional, a fábrica de ração proporcionou faturamento anual de $\mathrm{R} \$ 1,5$ milhão. Ocorre que o custo médio unitário de produção da ração é superior em $2,7 \%$ o preço médio de venda, fato que torna evidente o desequilíbrio financeiro, pois a Cooperativa está operando abaixo do ponto de nivelamento da atividade.

A usina de beneficiamento de leite ocupa área de $450 \mathrm{~m}^{2}$ e tem capacidade para processar 2.000 litros/dia, em turno de oito horas. A Cooperativa produz preponderantemente leite tipo C. A usina é suprida por 40 produtores que entregam, em média, 25 litros de leite diariamente. Em razão da baixa produtividade, os custos de produção são elevados. Para manter ativos os produtores, a Camapla os remunera com preço até $25 \%$ superior à cotação de mercado.

$\mathrm{Na}$ entressafra, os produtores da Camapla recebem até $\mathrm{R} \$ 0,40$ por litro de leite, enquanto o preço de mercado situa-se em torno de $R \$ 0,32$. Argumenta a Cooperativa que em razão dos elevados custos de produção do associado, não é recomendável praticar os preços de mercado e deixar os produtores em situação econômica ainda mais difícil. Atualmente, a ociosidade da usina é da ordem de $60 \%$, fato que contribui para o aumento dos custos da Cooperativa.

Nessas condições, a usina de leite é obrigada a operar com prejuízo estimado de $1,3 \%$ do faturamento líquido. Mantida a atual estrutura de produção, será necessário o processamento de pelo menos $30 \%$ de leite a mais para que se atinja o ponto de nivelamento da atividade.

Os serviços de mecanização agrícola representam cerca de $10 \%$ da receita da Camapla que dispõe dos seguintes equipamentos: seis tratores de pneus e um trator de esteira em bom estado de conservação, todos equipados para realização de aração, gradagem, pulverização, plantação etc. Atualmente, a Cooperativa presta serviços indistintamente a sócios e não-sócios, indispondo 
de instrumentos adequados para controle de horas trabalhadas, consumo de combustível e cobrança de serviços prestados.

A Camapla presta serviços de transporte em dois segmentos: serviços internos (remoção de tratores e perfuratrizes, transporte de matérias-primas para a fábrica de ração, transporte de mercadorias para abastecimento dos postos de revenda, transporte de leite para os pontos de distribuição); e serviços externos (transporte de produtos agrícolas dos associados para 0 mercado consumidor).

A Camapla mantém funcionando cinco postos de revenda de insumos agropecuários nos seguintes municípios: Angical do Piauí, Regeneração, Amarante, Jardim do Mulato e Água Branca. Por dificuldades de capital de giro, os preços praticados pela Cooperativa na revenda de insumos e materiais agropecuários são pouco competitivos ante a concorrência.

A política de preço adotada pela Camapla segue orientação do mercado com adaptação às pressões de ordem interna dos produtores dominantes. $\mathrm{Na}$ retirada de produtos da Cooperativa para pagamento a prazo não se cobra do associado a necessária margem de cobertura dos encargos financeiros, de forma que o capital de giro da Cooperativa fica comprometido.

A Cooperativa não mantém serviço especializado de assistência técnica. Ocasionalmente, os cooperados são assistidos por profissionais integrantes de empresas públicas de assistência técnica. Então, a precariedade desse serviço é responsável, em parte, pelos baixos índices de produtividade observados.

A situação financeira geral da Cooperativa é deficitária. As perdas acumuladas em 1998 alcançam R\$ 414 mil, correspondentes a 17,6\% de seu faturamento líquido. Nos três últimos exercícios sociais, ocorreram prejuízos operacionais em quase todos os segmentos explorados. $O$ endividamento geral 
da Camapla é da ordem de $68 \%$, enquanto o capital integralizado pelos associados representa apenas $8,3 \%$ dos fundos utilizados. $O$ imobilizado da Cooperativa representa $40 \%$ do ativo total, dimensionado em $R \$ 1,6$ milhão, em dezembro de 1998.

Finalmente, cumpre assinalar que situação semelhante à da Camapla pode ser verificada em muitas cooperativas do Nordeste, o que indica a necessidade de formulação e implementação de políticas adequadas para 0 segmento agropecuário. 


\section{DISCUSSÃO DOS RESULTADOS}

\subsection{Introdução}

As estatísticas foram geradas por meio da utilização do pacote de computação "Statistica", módulos "correspondence analysis" e "cluster analysis", distribuído pela Statsoft Inc.

Os métodos quantitativos empregados visam a encontrar possíveis associações entre os múltiplos atributos que caracterizam os objetos de estudo. Desta forma, é de interesse:

- comparar todas as cooperativas agropecuárias nordestinas integrantes da amostra entre si, com vistas a avaliar o grau de similaridade existente entre elas;

- avaliar o nível de associação existente entre as características observadas.

Portanto, o objetivo da análise é fundamentalmente construir uma tipologia para as cooperativas agropecuárias do Nordeste, que permita resumir o conjunto de características observadas em um pequeno número de fatores relevantes capazes de discriminar e identificar a existência de classes homogêneas. 


\subsection{Análise de correspondências múltiplas}

Com base na técnica de análise de correspondências múltiplas, a partir da utilização da matriz disjuntiva completa (Anexo 14), construída de conformidade com as regras dispostas na seção 3.6 , do capítulo 3 , foram obtidos os resultados adiante apresentados.

\subsubsection{Determinação do número de fatores}

As 22 modalidades referentes às oito variáveis consideradas no estudo incorporam inércia total de 1,75, que foi decomposta em 14 direções ortogonais entre si, conforme mostra o Quadro 12.

\begin{tabular}{|c|c|c|c|c|}
\hline \multicolumn{5}{|c|}{ Matriz de dados (linhas x colunas): $40 \times 22$} \\
Inércia total: 1,75 Chi2=560,0 $\quad$ df= 819 $\quad \mathrm{p}=1,000$ \\
\hline \multirow{2}{*}{ Dimensão } & Autovalor & $\begin{array}{c}\text { Percentual } \\
\text { da inércia }\end{array}$ & $\begin{array}{c}\text { Inércia } \\
\text { acumulada }\end{array}$ & Qui-quadrado \\
\hline 1 & 0,536 & 30,6 & 30,6 & 171,6 \\
2 & 0,276 & 15,8 & 46,4 & 88,5 \\
3 & 0,171 & 9,8 & 56,3 & 54,9 \\
4 & 0,152 & 8,7 & 64,9 & 48,7 \\
5 & 0,134 & 7,6 & 72,6 & 42,8 \\
6 & 0,100 & 5,8 & 78,3 & 32,2 \\
7 & 0,090 & 5,1 & 83,5 & 28,8 \\
8 & 0,071 & 4,1 & 87,6 & 22,9 \\
9 & 0,068 & 3,9 & 91,5 & 21,8 \\
10 & 0,046 & 2,6 & 94,1 & 14,8 \\
11 & 0,036 & 2,1 & 96,2 & 11,6 \\
12 & 0,032 & 1,9 & 98,1 & 10,4 \\
13 & 0,019 & 1,1 & 99,2 & 6,3 \\
14 & 0,014 & 0,8 & 100,0 & 4,7 \\
\hline
\end{tabular}

\section{Quadro 12. Autovalor e inércia.}

Fonte: dados da pesquisa.

O exame desses resultados indica que as cinco primeiras dimensões possuem autovalores superiores à média, incorporando, conjuntamente, $72,6 \%$ da dispersão total da nuvem de pontos. 
Contudo, observa-se que os dois primeiros eixos fatoriais captam grande proporção da inércia e que a retenção de uma dimensão adicional proporciona ganhos marginais decrescentes, conforme mostrado na Figura 7.

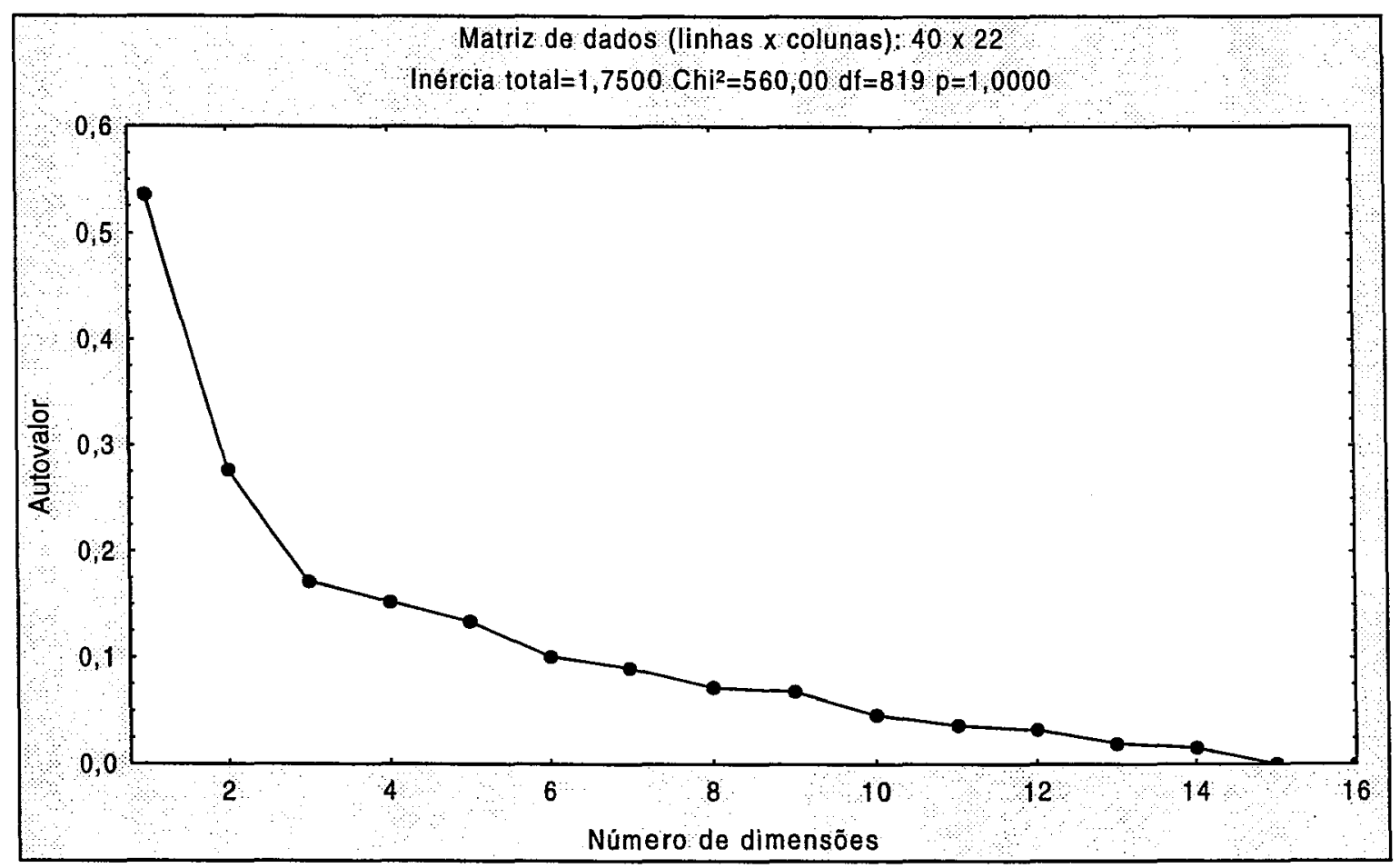

Figura 7. Representação dos autovalores por dimensão.

Fonte: dados da pesquisa.

Assim sendo, e como forma de imprimir tom mais objetivo durante a exposição dos resultados, a análise de correspondências múltiplas focalizará apenas as duas primeiras dimensões.

No entanto, cumpre esclarecer que, para fins de agrupamento das cooperativas em classes, matéria objeto da seção seguinte, serão considerados todos os fatores com autovalores positivos, a fim de evitar perdas de informação. 


\subsubsection{Análise dos eixos fatoriais}

No Anexo 15 são apresentadas as coordenadas, as contribuições individuais para a inércia e a qualidade de representação das 22 modalidades relativas às oito variáveis escolhidas, nos dois primeiros eixos fatoriais.

A primeira dimensão capta $30,6 \%$ da variabilidade total, estando positivamente associada com as modalidades: T4 (cooperativa de grande porte); E1 (baixo nível de endividamento); Z3 (alto grau de escolaridade dos dirigentes) e N3 (elevado giro do ativo) e negativamente correlacionada com as modalidades: T1 (cooperativa de microporte); D1 (desempenho econômico precário) e E3 (elevado nível de endividamento).

Este eixo também põe em evidência expressiva separação entre as modalidades 11 (incipiente relacionamento institucional) e 12 (satisfatório relacionamento institucional) e também entre as modalidades F1 (cooperativa constituída até 4.10.1988) e F2 (cooperativa constituída a partir de 5.10.1988). Esta direção capta ainda a segregação entre as cooperativas no que se refere à intensidade de utilização de práticas administrativas.

A segunda dimensão capta $15,8 \%$ da variabilidade total. É positivamente associada com as modalidades T4 (cooperativas de grande porte) e E1 (baixo nível de endividamento) e negativamente associada com a modalidade N2 (índice de giro do ativo moderado), D2 (desempenho econômico regular) e Z1 (baixo grau de escolaridade dos dirigentes). 


\subsubsection{Análise do primeiro plano fatorial}

A representação gráfica das modalidades, dispostas no plano formado pelos dois primeiros eixos fatoriais, é mostrada na Figura 8.

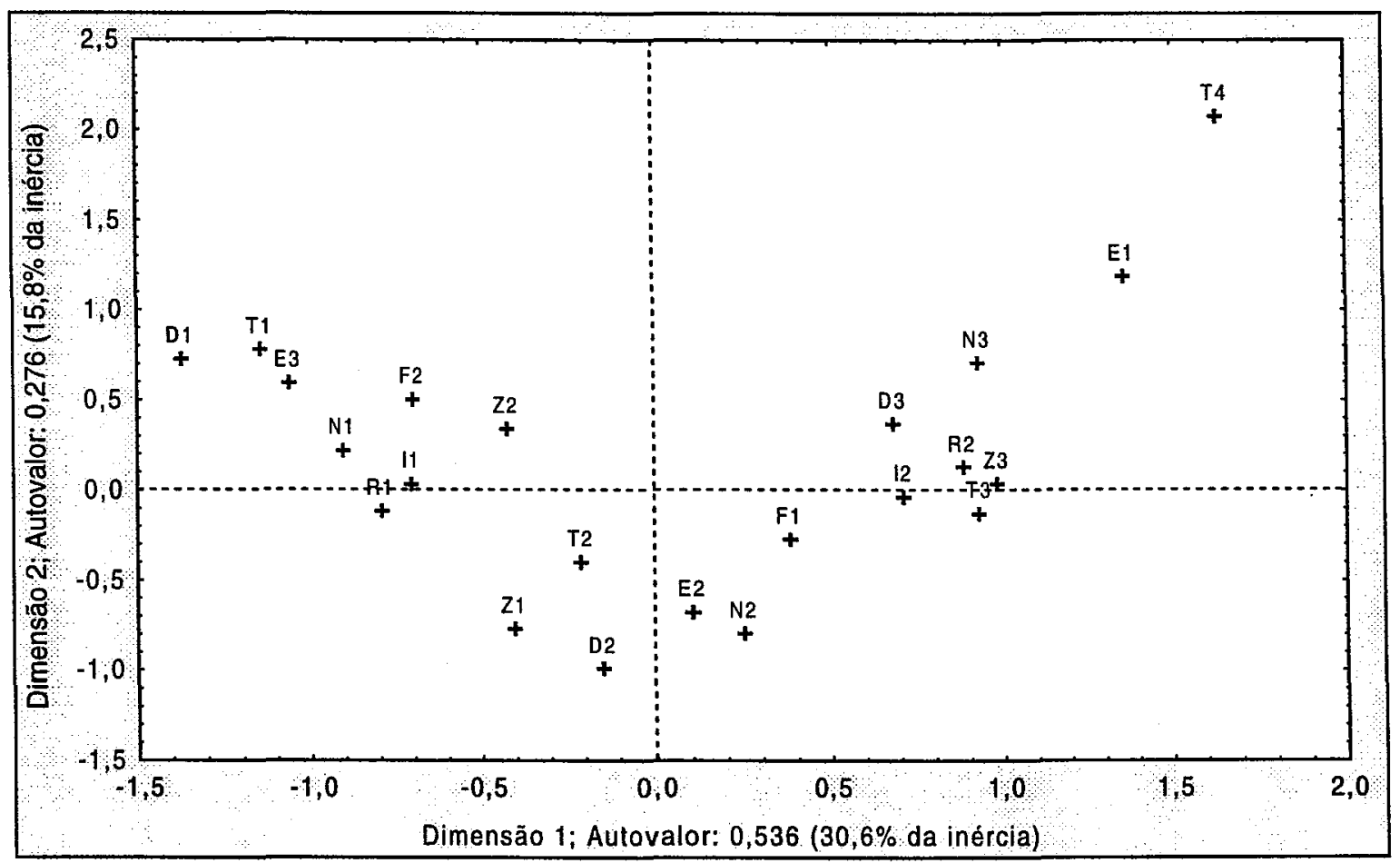

Figura 8. Representação das variáveis no primeiro plano fatorial.

Fonte: dados da pesquisa.

Nota-se que as modalidades consideradas aglomeram-se em três zonas distintas:

- a primeira, situada à direita, ocupando, predominantemente, o primeiro quadrante, reúne as modalidades de variáveis que denotam as seguintes características: cooperativas de maior porte, cujo nível de atividade econômica é mais intenso, que possuem maior interação com outras organizações e fazem uso mais intensivo de técnicas de administração profissional; 
- a segunda, localizada no terceiro e quarto quadrantes, agrega indicadores de cooperativas de porte intermediário, com moderado nível de atividade econômica e de endividamento;

- a última, situada mais à esquerda, no segundo quadrante, junta as modalidade denotativas de cooperativas de pequeno porte, cujo nível de atividade econômica é incipiente, que possuem pouca inserção institucional.

A Figura 9 retrata os indivíduos no primeiro plano fatorial, permitindo que cada uma das 40 cooperativas da amostra seja representada segundo o conjunto de dados qualitativos a elas atribuído. Por limitação de espaço, foram empregadas letras maiúsculas e minúsculas em substituição à denominação das cooperativas (Ver Anexo 16).

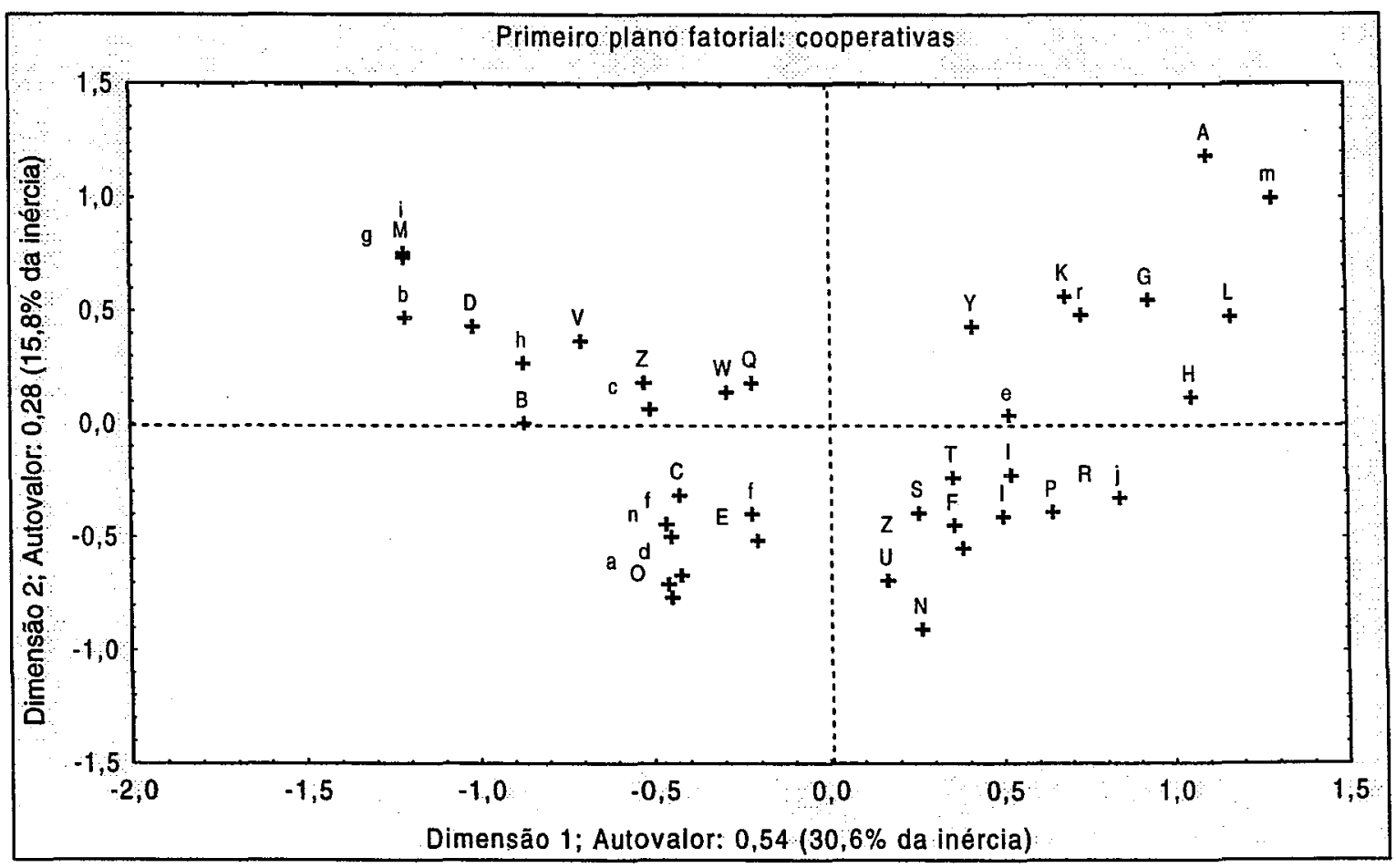

Figura 9. Representação das cooperativas no primeiro plano fatorial.

Fonte: dados da pesquisa. 
A interpretação precedente feita para as modalidades das variáveis é igualmente válida para os indivíduos (cooperativas).

\subsection{Análise de classificação}

A mesma matriz de dados que serve de base à análise de correspondências é também empregada para efetuar a classificação e agrupamento das observações.

Inicialmente, foi aplicado um procedimento de classificação hierárquica direta, pelo critério de agregação vizinho mais distante. O resultado obtido sugere a segregação das cooperativas em três classes, conforme representado na Figura 10.

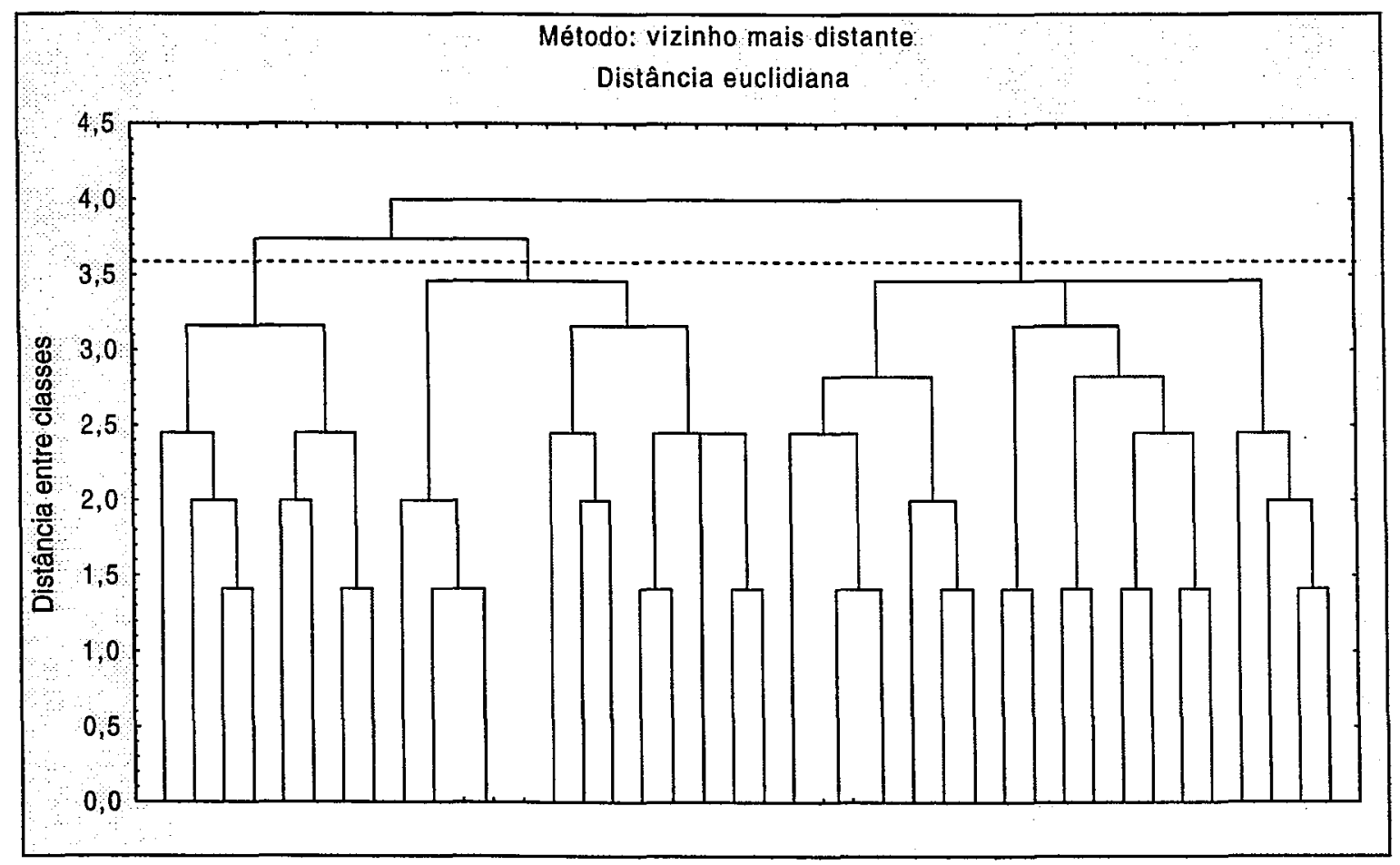

Figura 10. Dendrograma: cooperativas.

Fonte: dados da pesquisa. 
Definido o número de classes, partiu-se para a alocação dos indivíduos nos grupos, mediante a realização de sucessivas iterações, até a obtenção de partição que seja a mais homogênea possível intraclasse e o mais heterogênea interclasse.

A composição dos grupos, com a indicação da distância euclidiana de cada indivíduo (cooperativa) ao baricentro da classe, é apresentada no Anexo 16.

Considerados os atributos gerais do conjunto dos indivíduos de cada classe, far-se-á uso indicativo da seguinte denominação:

- grupo A: cooperativas de difícil recuperação;

- grupo B: cooperativas revitalizáveis;

- grupo C: cooperativas potencialmente dinâmicas.

A exposição das características dos referidos grupos será feita nas seções seguintes, sendo remetido para os Anexos 17, 18 e 19 o cotejamento entre eles.

\subsubsection{Descrição das cooperativas do grupo A}

Conforme apresentado no Anexo 16, este grupo é constituído por 20 cooperativas: Comasil, Cooperbal, Cocedro, Coopagrol, Caplo, Betânia, Coopacam, Cooperhort, Cooserrana, Coopersanta, Caipig, Coamiga, Goitá, Coagril, Camicil, Coopaqui, Cooami, Campic, Camic e Coopi.

As cooperativas do grupo $\mathrm{A}$ caracterizam-se pelo pequeno número de associados, elevado nível de endividamento e incipiente nível de atividade econômica. Essas organizações também apresentam baixo nível de relacionamento institucional e, praticamente, não dispõem de instrumentação adequada para controle gerencial. 
Conforme apresentado na Tabela 40, as cooperativas do grupo possuem quadro social bastante reduzido, composto em média de 328 cooperados, sendo três quintos delas constituídas por menos de 200 associados e as maiores não ultrapassando 1.000 filiados, na posição de 31.12.1998.

Tabela 40. Grupo A: número de associados.

\begin{tabular}{lccccccc}
\hline Ano & Média & Mediana & $\begin{array}{c}\text { Desvio } \\
\text { padrão }\end{array}$ & Mínimo & Máximo & $\begin{array}{c}\text { Coeficiente } \\
\text { de variação observações }\end{array}$ \\
\hline 1998 & 328 & 174 & 302 & 36 & 998 & 0,921 & 20 \\
1997 & 329 & 171 & 313 & 36 & 998 & 0,951 & 18 \\
1996 & 367 & 220 & 314 & 43 & 998 & 0,856 & 16 \\
\hline
\end{tabular}

Fonte: dados da pesquisa.

As cooperativas deste grupo possuem, em média, carteira de repasse a cooperados cujo volume de negócios corresponde a $68,8 \%$ do ativo total, denotando que as demais atividades empresariais são de somenos importância.

As estatísticas apresentadas na Tabela 41 mostram que tais cooperativas possuem ativos médios de $R \$ 2.545$ mil, dos quais apenas $R \$ 245$ mil constituem aplicações em inversões permanentes voltadas para atividades produtivas.

$\mathrm{Na}$ oportunidade, cumpre registrar a existência de cooperativas, nesse grupo, sem nenhum ativo operacional, o que reforça a hipótese de que foram constituídas com o fim exclusivo de intermediação de créditos de repasse. 
Tabela 41. Grupo A: indicadores de estrutura econômica e patrimonial.

Valores em $\mathrm{R} \$ 1.000$

\begin{tabular}{lrrrrrr}
\hline Grupo contábil & Média & Mediana & $\begin{array}{l}\text { Desvio } \\
\text { padrão }\end{array}$ & Mínimo & Máximo & $\begin{array}{c}\text { Coeficiente } \\
\text { de variação }\end{array}$ \\
\hline Ativo total & 2.545 & 2.324 & 1.836 & 83 & 7.201 & 0,721 \\
Cart. Repasse & 1.751 & 1.784 & 1.362 & 0 & 4.678 & 0,778 \\
Imobilizado & 245 & 202 & 207 & 3 & 621 & 0,845 \\
Passivo circulante & 270 & 85 & 608 & 0 & 2.780 & 2,252 \\
P.Exigível LP & 2002 & 2.009 & 1.362 & 0 & 4.808 & 0,619 \\
Patrim. Liquido & 273 & 264 & 215 & -92 & 668 & 0,788 \\
Faturamento & 178 & 174 & 149 & 0 & 485 & 0,837 \\
\hline
\end{tabular}

Fonte: dados da pesquisa.

Como conseqüência dessa situação, o nível de atividade econômica é extremamente baixo e, em certas cooperativas até inexistente. Constatou-se que em oito das 20 cooperativas classificadas no grupo $A$ não há geração própria de receitas, exceto as de origem financeira. Em média, o giro operacional deste grupamento situa-se em torno de $6,9 \%$ do ativo total.

As poucas atividades econômicas que foram identificadas concentram-se na exploração de loja de revenda de produtos agropecuários e na prestação de serviços de mecanização agrícola. Conforme mostrado na Tabela 42, essas duas atividades representam $67 \%$ das receitas líquidas agregadas do grupo. Esse nível de faturamento corresponde a receitas médias de $\mathrm{R} \$ 500$ por associado, magnitude essa 38 vezes menor que a média observada no cooperativismo agropecuário nacional. 
Tabela 42. Grupo A: composição do faturamento.

\begin{tabular}{lcr} 
& \multicolumn{2}{c}{ Valores em R\$ mil } \\
\hline Composição das receitas & Faturamento & $\%$ \\
\hline Insumos agropecuários & 1.203 & 33,8 \\
Serviço de mecanização agrícola & 1.178 & 33,2 \\
Comercialização de algodão & 461 & 13,0 \\
Beneficiamento de leite & 420 & 11,8 \\
Comercialização de milho & 239 & 6,7 \\
Outros produtos & 55 & 1,5 \\
\hline Total & 3.556 & 100,0 \\
\hline
\end{tabular}

Fonte: dados da pesquisa.

Assim sendo, em razão de operarem com escala inadequada e possuírem alto grau de ineficiência interna, estas cooperativas apresentam perdas da ordem de $8,6 \%$ do patrimônio líquido.

Finalmente, merece destaque o fato de as cooperativas do grupo serem excessivamente alavancadas. Com efeito, a proporção de capitais de terceiros nos fundos administrados por tais organizações é da ordem de $89,3 \%$, havendo casos em que praticamente inexiste participação de capital próprio.

\subsubsection{Descrição das cooperativas do grupo B}

Este grupo é constituído por 10 cooperativas: Coapil, Coopermil, Coiguatu, Cervap, Coopar, Coopag, Coicó, Coerba, Coopalto e Camagil.

As cooperativas classificadas no grupo B possuem, em média, quadro social composto de cerca de 1.003 associados, com expressiva variância, conforme indicado na Tabela 43. 
Tabela 43. Grupo B: número de associados.

\begin{tabular}{lccccccc}
\hline Ano & Média & Mediana & $\begin{array}{c}\text { Desvio } \\
\text { padrão }\end{array}$ & Mínimo & Máximo & $\begin{array}{c}\text { Coeficiente } \\
\text { de variação }\end{array}$ & $\begin{array}{c}\text { Número de } \\
\text { observações }\end{array}$ \\
\hline 1998 & 1.003 & 781 & 691 & 324 & 2.418 & 0,689 & 10 \\
1997 & 948 & 685 & 695 & 324 & 2.418 & 0,733 & 10 \\
1996 & 924 & 674 & 686 & 324 & 2.418 & 0,742 & 10 \\
\hline
\end{tabular}

Fonte: dados da pesquisa.

Referidas cooperativas possuem ativos operacionais médios de $R \$ 5,0$ milhões, dos quais $50,7 \%$ referem-se a operações de repasse a cooperados e $17,6 \%$ representam imobilizações permanentes, conforme apresentado na Tabela 44.

Tabela 44. Grupo B: indicadores de estrutura econômica e patrimonial. Valores em $\mathrm{R} \$ 1.000$

\begin{tabular}{lrrrrrr}
\hline Grupo contábil & Média & Mediana & $\begin{array}{r}\text { Desvio } \\
\text { padrão }\end{array}$ & Mínimo & Máximo & $\begin{array}{c}\text { Coeficiente de } \\
\text { variação }\end{array}$ \\
\hline Ativo total & 5.027 & 4.360 & 2.486 & 2.280 & 9.629 & 0,495 \\
Cart. Repasse & 2.549 & 2.027 & 1.655 & 0 & 5.245 & 0,649 \\
Imobilizado & 883 & 768 & 534 & 295 & 2.018 & 0,605 \\
Passivo circulante & 780 & 739 & 526 & 139 & 1.638 & 0,674 \\
P.Exigivel L. Prazo & 3.088 & 2.194 & 1.616 & 1.375 & 6.029 & 0,523 \\
Patrim. Liquido & 1.159 & 1.109 & 544 & 461 & 2.070 & 0,469 \\
Faturamento & 1.136 & 1.001 & 883 & 239 & 3.434 & 0,777 \\
\hline
\end{tabular}

Fonte: dados da pesquisa.

Portanto, são organizações de porte econômico considerado moderado se comparado às grandes cooperativas brasileiras, cuja média supera $R \$ 25$ milhões de ativos operacionais.

O exame dos números precedente revela que tais cooperativas dispõem apenas de $23,1 \%$ de capitais próprios, sendo o restante captado no mercado financeiro. Essa situação de endividamento elevado, agrava-se em virtude do baixo nível de atividade econômica dessas cooperativas. O faturamento líquido corresponde apenas a $22,6 \%$ ativo total, indicando a existência de ociosidade dos fatores de produção. 
Conforme mostrado na Tabela 45, as receitas das cooperativas desse grupo originam-se da comercialização de produtos agrícolas e da prestação de serviços diversos. O faturamento médio situa-se em torno de $\mathrm{R} \$ 1.100$ por associado, portanto, ainda muito distante da média do cooperativismo agropecuário nacional.

Tabela 45. Grupo B: Composição do faturamento.

\begin{tabular}{lcr} 
& \multicolumn{2}{c}{ Valores em R\$ mil } \\
\hline Composição das receitas & Faturamento & $\%$ \\
\hline Comercialização de algodão & 2.780 & 24,5 \\
Insumos agropecuários & 1.984 & 17,5 \\
Serviço de eletrificação rural & 1.737 & 15,3 \\
Castanha de caju & 1.260 & 11,1 \\
Comercialização de arroz & 980 & 8,6 \\
Supermercado & 784 & 6,9 \\
Serviço de mecanização & 690 & 6,1 \\
Beneficiamento de leite & 498 & 4,4 \\
Outros produtos agropecuários & 372 & 3,3 \\
Serviços de transporte & 271 & 2,4 \\
\hline Total & 11.356 & 100,0 \\
\hline
\end{tabular}

Fonte: dados da pesquisa.

Todas as cooperativas do grupo B foram constituídas até os anos oitenta. A estrutura produtiva delas pode ser considerada ultrapassada e está voltada para atividades que vêm perdendo importância nos últimos anos. É o caso da cultura do algodão que, entre 1985 e 1995, sofreu redução de 90\% da área colhida. A cajucultura é outra atividade que experimentou quedas de produtividade. Assim sendo, por falta de matérias-primas, os equipamentos de beneficiamento e armazéns das cooperativas mantêm-se inutilizados, gerando custos de oportunidade irreparáveis. Por outro lado, são comuns os resultados deficitários das atividades de mecanização e transporte de produtos primários, em virtude dos altos custos fixos envolvidos. A confluência de todos esses fatores compromete o desempenho dessas organizações, que vêm operando com perdas correspondentes a $4,45 \%$ do patrimônio líquido. 


\subsubsection{Descrição das cooperativas do grupo C}

Este grupo é constituído por dez cooperativas: Capivab, Civab, Coopmova, Coopagro, Coopamn, Capi, Batavo Nordeste, Campal, Frucoop e Campib.

Referidas organizações têm como traços marcantes o maior porte econômico e maior participação na comercialização da produção agrícola e agroindustrialização de matérias-primas oriundas da unidade produtiva do produtor associado. $80 \%$ das cooperativas deste grupo foram constituídas antes de 1989, sendo exceção apenas a Batavo Nordeste e a Frucoop.

Conforme se observa na Tabela 46, as cooperativas deste grupo são constituídas, em média, por 877 associados. Três delas possuem mais de 1.000 associados e seis cooperativas reúnem menos de 300 produtores rurais. $A$ grande dispersão dessa variável indica que o número de associados não constitui fator determinante de sucesso na condução de empreendimento econômico. Há tanto grandes quanto pequenas cooperativas com boa performance empresarial.

Tabela 46. Grupo C: número de associados.

\begin{tabular}{lccccccc}
\hline Ano & Média & Mediana & $\begin{array}{c}\text { Desvio } \\
\text { padrão }\end{array}$ & Mínimo & Máximo & $\begin{array}{c}\text { Coeficiente } \\
\text { de variação }\end{array}$ & $\begin{array}{c}\text { Número de } \\
\text { observações }\end{array}$ \\
\hline 1998 & 877 & 258 & 1.351 & 41 & 4.448 & 1,541 & 10 \\
1997 & 899 & 267 & 1.360 & 41 & 4.420 & 1,513 & 10 \\
1996 & 975 & 301 & 1.373 & 44 & 4.328 & 1,408 & 9 \\
\hline
\end{tabular}

Fonte: dados da pesquisa.

Os números da Tabela 47 demonstram que o giro operacional das cooperativas do grupo situa-se em torno de $84,9 \%$, denotando o melhor desempenho entre as cooperativas da amostra. 
Tabela 47. Grupo C: indicadores de estrutura econômica e patrimonial.

\begin{tabular}{lrrrrrr} 
& & & & \multicolumn{2}{c}{ Valor em R\$ 1.000 } \\
\hline Grupo contábil & Média & Mediana & $\begin{array}{c}\text { Desvio } \\
\text { padrão }\end{array}$ & Mínimo & Máximo & $\begin{array}{c}\text { Coeficiente de } \\
\text { variação }\end{array}$ \\
\hline Ativo total & 6.450 & 3.426 & 7.506 & 37 & 23.468 & 1,164 \\
Cart. de Repasse & 541 & 628 & 467 & 0 & 1.378 & 0,863 \\
Imobilizado & 2.007 & 605 & 3.177 & 25 & 9.999 & 1,583 \\
Passivo circulante & 1.497 & 783 & 1.872 & 12 & 6.005 & 1,251 \\
P.Exigivel L. Prazo & 2.330 & 1.534 & 3.133 & 21 & 10.957 & 1,345 \\
Patrim. Liquido & 2.623 & 947 & 3.550 & 4 & 9.423 & 1,353 \\
Faturamento & 5.473 & 2.635 & 7.060 & 694 & 22.977 & 1,290 \\
\hline
\end{tabular}

Fonte: dados da pesquisa.

O nível médio de endividamento é relativamente moderado, situando-se em torno de $59,3 \%$ dos fundos utilizados. Fato digno de nota é a baixa proporção das operações de repasse que representa apenas $8,4 \%$ do ativo total agregado das cooperativas consideradas.

Estas cooperativas prestam maior assistência ao associado: $60 \%$ possuem loja de revenda de insumos agropecuários; $80 \%$ delas prestam serviços de mecanização agrícola e $70 \%$ realizam atividades de agroindustrialização de matérias-primas.

A Tabela 48 mostra a composição do faturamento das cooperativas classificadas no grupo $\mathrm{C}$, indicando concentração de $71,8 \%$ nas atividades de comercialização de insumos agropecuários, leite, arroz e soja. 
Tabela 48. Grupo C: composição do faturamento.

\begin{tabular}{lcr} 
& \multicolumn{2}{c}{ Valores em R\$ mil } \\
\hline Composição das receitas & Faturamento & $\%$ \\
\hline Insumos agropecuários & 12.806 & 23,4 \\
Comercialização de leite & 10.306 & 18,8 \\
Comercialização de arroz & 8.584 & 15,7 \\
Comercialização de soja & 7.599 & 13,9 \\
Posto de combustível & 2.779 & 5,1 \\
Comercialização de algodão & 3.668 & 6,7 \\
Comercialização de frutas & 2.155 & 3,9 \\
Supermercado & 3.912 & 7,1 \\
Outros produtos agropecuários & 2.919 & 5,3 \\
\hline Total & 54.728 & 100,0 \\
\hline
\end{tabular}

Fonte: dados da pesquisa.

O faturamento médio por associado situa-se em torno de $\mathrm{R} \$ 6,2$ mil, o que corresponde a cerca de $32,6 \%$ do padrão observado no segmento agropecuário nacional. Portanto, mesmo as supostas melhores cooperativas do Nordeste apresentam índices de vitalidade econômica aquém dos observados na economia cooperativa nacional.

Mesmo apresentando nível de atividade econômica mais intenso que os demais grupos, essas cooperativas operam com perdas correspondentes a 1,33\% do patrimônio líquido.

\subsubsection{Considerações finais sobre os resultados da análise de classificação}

Apenas as cooperativas do grupo $\mathrm{C}$ apresentam certo dinamismo nas atividades exploradas, embora também operem com perdas. Representando $25 \%$ da amostra, participam de $78,6 \%$ do faturamento agregado das 40 cooperativas examinadas. A participação das cooperativas do grupo B situa-se em $16,3 \%$, enquanto as do grupo $A$, que correspondem a $50 \%$ da amostra, 
participam de apenas $5,1 \%$ do faturamento do conjunto das organizações examinadas.

Nas cooperativas dos grupos A e B, respectivamente, $68,8 \%$ e $50,7 \%$ do ativo é constituído de operações de repasse. Já as cooperativas do grupo $\mathrm{C}$ adotaram a estratégia de não atuar de forma massiva na área de crédito pois as operações de repasse representam apenas $8,4 \%$ do ativo total. Em virtude dessa conduta, o nível de endividamento delas apresenta-se em patamar inferior à média do cooperativismo nacional.

É provável que as cooperativas do grupo A venham a enfrentar problemas de liquidez que levarão muitas à condição de insolvência civil. Contudo, considerando que $70 \%$ delas não realizam atividades de comercialização de produtos agrícolas, os impactos na economia individual dos associados não causarão maiores transtornos, exceto para seus credores.

As cooperativas do grupo B também padecem do mal do endividamento, mas têm a seu favor a tradição de muitos anos no mercado. Essas cooperativas deverão passar por amplo processo de reestruturação interna, com vistas a desativar segmentos deficitários, em prol de atividades que adicionem valor à empresa. Logo, ações no sentido de desimobilização de ativos ociosos e fusão com outras cooperativas são alternativas que não podem ser desconsideradas.

As cooperativas do grupo $\mathrm{C}$ deverão trabalhar ações de monitoramento dos associados a fim de incrementar a utilização de seus ativos operacionais. Para tanto, faz-se necessário o aporte de recursos destinados ao financiamento de capital de giro, bem como a modernização da plataforma operacional que dá suporte às atividades-chaves. 
A discussão precedente sobre as características das três classes de cooperativas indica a necessidade de adoção de políticas específicas para cada segmento do cooperativismo agropecuário nordestino. 


\section{CONCLUSÕES E RECOMENDAÇÕES}

\subsection{Perfil da agricultura cooperativa brasileira}

Os resultados da análise de componentes principais e de agrupamentos mostram que a agricultura cooperativa brasileira pode ser classificada em cinco regiões relativamente homogêneas quanto ao grau de modernização, índices de produtividade e filiação ao cooperativismo:

- região 1: ES, GO, MG, MT, RJ - agricultura de adiantado estágio de modernização que apresenta altos índices de produtividade, utilização predominante de mão-de-obra contratada, cerca de $57,7 \%$ da população ocupada, e moderado nível de filiação ao cooperativismo, alcançando $19,9 \%$ dos estabelecimentos agropecuários. Nesta região, $29,8 \%$ das propriedades utilizam trator, $54,0 \%$ dispõem de serviços de assistência técnica, $79,5 \%$ possuem energia elétrica e $73,5 \%$ fazem fertilização artificial do solo;

- região 2: $\mathrm{AL}, \mathrm{BA}, \mathrm{CE}, \mathrm{MA}, \mathrm{PB}, \mathrm{PE}, \mathrm{RN}, \mathrm{SE}, \mathrm{TO}$ - agricultura atrasada do ponto de vista tecnológico, apresentando baixos níveis de produtividade dos fatores, em especial do trabalho, e incipiente índice de filiação ao cooperativismo, apenas $2,9 \%$ dos estabelecimentos agropecuários. Só $9,2 \%$ das propriedades utilizam trator, $28,6 \%$ são beneficiadas por serviços de assistência 
técnica, $50,8 \%$ possuem energia elétrica e 44,8\% realizam fertilização do solo;

- região 3: DF, MS, SP - agricultura que apresenta os maiores índices de produtividade e de modernização do País. $58 \%$ das propriedades rurais utilizam trator, $69,3 \%$ são beneficiadas por serviços de assistência técnica, $80,6 \%$ possuem energia elétrica e $79,4 \%$ realizam fertilização química ou orgânica do solo. O nível de filiação a cooperativas alcança $28,2 \%$ das unidades produtivas. Nesta região, há uso intensivo da terra e predomínio do emprego de mão-de-obra contratada, que representa $65,0 \%$ da população ocupada, o que denota traços de uma agricultura de natureza comercial. A presença de administradores contratados em 15,9\% dos estabelecimentos agropecuários indica a tendência de profissionalização da agricultura cooperada em referida região;

- região 4: AC, AM, AP, PA, PI, RO, RR - constitui o espaço regional de agricultura mais atrasada do País, apresentando baixos níveis de produtividade, notadamente da terra, e de filiação ao cooperativismo, compreendendo apenas $2,8 \%$ dos estabelecimentos agropecuários. Relativamente às variáveis tecnológicas, só $4,7 \%$ das propriedades utilizam trator, $25 \%$ dispõem de serviços de assistência técnica, $23,9 \%$ têm energia elétrica e $22,6 \%$ fazem uso de técnicas de fertilização do solo. Nessa região, há preponderância da agricultura familiar que representa $77,2 \%$ da população ocupada, enquanto os empregados temporários e permanente são apenas $15,1 \%$ e $7,7 \%$, respectivamente, do mesmo contingente;

- região 5: PR, RS, SC - agricultura com elevado nível de modernização tecnológica cuja força de trabalho provém dominantemente da base familiar visto que somente $20,0 \%$ da 
população ocupada é constituída de empregados contratados, dos quais apenas $9,7 \%$ em caráter permanente. $36,5 \%$ das propriedades utilizam trator, $66,8 \%$ são beneficiadas por serviços de assistência técnica, $83,2 \%$ dispõem de energia elétrica e $90,6 \%$ fazem fertilização química ou orgânica do solo. É nessa região que se verificam o mais alto índice de filiação ao cooperativismo, cerca de $37,2 \%$ das unidades de produção rural, e a maior proporção de estabelecimentos agropecuários beneficiados por mecanismos de crédito. Contrariamente ao observado nas demais regiōes desenvolvidas, apenas $3,2 \%$ das unidades produtivas são administradas por gerentes contratados.

A regionalização adotada mostra que a prática da cooperação é mais efetiva nos centros de agricultura mais desenvolvida, indicando que a base produtiva do associado é condição necessária, embora não suficiente, para o sucesso do cooperativismo agropecuário.

\subsection{Situação da agricultura cooperativa nordestina}

O cooperativismo agropecuário possui pouca expressão econômica na agricultura do Nordeste do Brasil. Apenas 2,8\% dos estabelecimentos existentes, que representam $14 \%$ da renda agropecuária bruta regional, são filiados a cooperativas. Esta performance é muito inferior à média nacional de $14,2 \%$ no nível de adesão ao cooperativismo e à participação deste na formação de $41,2 \%$ da renda bruta da agropecuária brasileira.

Os cooperados nordestinos têm poucas relações econômicas com suas cooperativas, diferentemente do que ocorre nas regiões Sul e Sudeste do País, onde essas empresas absorvem mais de $50 \%$ da produção cooperada. Os resultados do Censo Agropecuário 1995-96 do IBGE revelam que apenas $10,5 \%$ da produção dos cooperados nordestinos são comercializadas por meio 
de cooperativas. Portanto, a renda dos produtores cooperados do Nordeste tem menor dependência das transações econômicas intermediadas pelas cooperativas.

A explicação para a aludida conduta provavelmente reside nos baixos excedentes econômicos gerados pelos cooperados que, em sua maịoria, desenvolvem atividades agropecuárias com uso de técnicas primitivas de produção. Com isso, além dos baixos niveis de produtividade obtidos, há irregularidades no fluxo de oferta da produção, nem sempre atingindo escala mínima que justifique a comercialização ou o beneficiamento pelas cooperativas.

O sistema de produção predominante envolve a criação de animais, conjugada com a exploração de lavouras de subsistência e pelo menos uma cultura de maior densidade econômica: cana-de-açúcar (na Zona da Mata de Pernambuco e Alagoas), algodão, coco, cacau (na Bahia) e frutas tropicais (nos vales úmidos).

Os produtos em que a participação de cooperativas é mais efetiva são leite, arroz e soja. A lavoura de arroz está mais presente nos perímetros públicos de irrigação constituídos até meados dos anos oitenta, tendo a cooperativa função supridora de insumos agropecuários básicos, armazenamento e comercialização da produção, além da representação institucional dos produtores cooperados. A exploração de soja está associada a grandes projetos privados de colonização iniciados há 20 anos nos cerrados da Bahia e, mais recentemente, no sul do Maranhão e do Piauí. A pecuária leiteira está disseminada indistintamente em toda a região. Observou-se ainda que a atividade de sustentação, responsável por cerca de um quinto do faturamento das cooperativas, é a revenda de insumos agropecuários.

O cooperativismo agropecuário está presente em todo o Nordeste, com distribuição heterogênea nos espaços geoeconômicos. Nos estados do 
Maranhão, Piauí e Sergipe, a participação econômica do cooperativismo agrícola é incipiente, atingindo menos de $2 \%$ do número de estabelecimentos agropecuários. No estado do Rio Grande do Norte, a participação relativa do cooperativismo na economia agrícola é da ordem de $24,2 \%$ do valor da produção agropecuária bruta, distribuída em 10,3\% dos estabelecimentos agropecuários. Em Alagoas, a economia cooperada representa $39,7 \%$ de toda a agricultura estadual, porém está concentrada espacialmente na mesorregião do Leste Alagoano com a cultura da cana-de-açúcar. É o espaço regional em que o cooperativismo mais se aproxima da média nacional no que diz respeito aos indicadores de modernização e produtividade. Em termos absolutos, destacamse os estados da Bahia e de Alagoas, que, conjuntamente, possuem quase metade da renda agropecuária bruta e $40,1 \%$ do pessoal ocupado na agricultura cooperada nordestina.

\subsection{Conclusões}

A condição basilar para o desenvolvimento de cooperativas está intimamente associada à real necessidade de um grupo de produtores colocar de forma mais vantajosa seus produtos na cadeia de produção e consumo. Considerando que nem sempre as cooperativas conseguem ser efetivas, há tendência natural de afastamento do sócio que procura no mercado outras alternativas de negócio.

Na região Nordeste predominam as cooperativas agropecuárias mistas, que exploram múltiplos produtos e atividades. $\mathrm{Na}$ amostra de cooperativas analisadas, verificou-se que $67,5 \%$ delas exploram pelo menos quatro produtos econômicos e numerosas atividades internas de prestação de serviços ao associado: mecanização agrícola, transporte de produtos, repasse de crédito, armazenamento entre outras. 
Essa proliferação de atividades implica a necessidade de estruturação de plataformas operacionais para o desenvolvimento de empreendimentos nem sempre sinérgicos entre si. Sintoma disto pôde ser percebido na apresentação do caso da Cooperativa Agrícola Mista de Angical do Piauí (Camapla), que mantém sob a mesma organização produtores de leite, avicultores, produtores de milho e produtores de arroz. Evidente que o produtor de milho ao reivindicar melhores condições para o seu produto poderá estar onerando os custos operacionais dos produtores de aves. Daí, as freqüentes disputas políticas internas, que não raro provocam cisões e dissidências no interior da organização cooperativa. Para conciliar tais questões, as cooperativas procuram atender a todos, tornando-se um conglomerado de atividades pouco relacionadas, em prejuizo da competitividade geral da organização.

Os problemas verificados nas cooperativas nordestinas podem ser sintetizados nos seguintes pontos:

- escassa capacidade de formação de poupança - $70 \%$ dos estabelecimentos agropecuários filiados a cooperativas produzem renda agropecuária bruta anual inferior a $R \$ 4,7$ mil, indicando a existência de baixa propensão marginal à poupança;

- baixo incentivo à capitalização - as limitações de ordem legal e doutrinária à remuneração do fator capital no cooperativismo desestimulam a capitalização voluntária pelos produtores que detêm rendimentos mais elevados, ou seja, os que exploram os demais estabelecimentos agropecuários cuja renda média anual aproximase de $\mathrm{R} \$ 40 \mathrm{mil}$;

- direitos de propriedade difusos - a baixa rentabilidade dos empreendimentos conduzidos pelas cooperativas, aliada à incerteza de distribuição de sobras, e o inexpressivo nível de integralização do 
capital próprio, fazem com que o produtor não se sinta proprietário da empresa cooperativa. No período considerado, a rentabilidade do conjunto das cooperativas analisadas foi negativa, registrando-se poucas que apresentaram sobras, mesmo assim pequenas ante a dimensão dos ativos operacionais existentes. Por outro lado, a política interna de preços adotada pelas cooperativas são pouco atuantes, dada a ação de concorrentes que atraem geralmente os melhores e maiores produtores rurais. Quanto à essa vertente, menos de um quinto das cooperativas que realizam comercialização e/ou industrialização da produção pratica preços diferenciados por qualidade, quantidade ou regularidade na oferta de matérias-primas oriundas dos cooperados;

- incipiente nível de profissionalização da gestão - a direção das cooperativas agropecuárias no Nordeste é realizada, em geral, por cooperados de baixo nível de escolaridade, prejudicando a adoção de técnicas de administração profissional;

- endividamento elevado - verificou-se que o endividamento médio das cooperativas é da ordem de $74 \%$ dos fundos utilizados, chegando a mais de $90 \%$ em determinados casos. Esta situação torna-se mais grave devido ao fato de referidas organizações possuírem baixo giro operacional. Com efeito, o estoque de dívidas das cooperativas do Nordeste representa, em média, 176\% de seu faturamento. Para o conjunto das cooperativas agropecuárias brasileiras, estima-se um estoque de dívidas bancárias e nãobancárias da ordem de $R \$ 4,4$ bilhões e um faturamento de $R \$ 13,2$ bilhões. Portanto, considerando a capacidade de pagamento, o nível de endividamento das cooperativas nordestinas apresenta-se, em termos relativos, cinco vezes superior à média brasileira; 
- freqüente inadequação de escala - registra-se não desprezível ociosidade da capacidade instalada das cooperativas, cujos ativos vêm sendo mantidos a elevado custo de capital, derivado de financiamentos bancários. Verificou-se que em $3 / 4$ das cooperativas da amostra, o faturamento líquido agregado médio não atinge $15 \%$ do ativo total;

- deficiente inserção no mercado - por atuarem em diversos mercados de produtos, as cooperativas do Nordeste não conseguem ser competitivas em mercados específicos;

- debilidade da base produtiva - com exceção das lavouras de cana-de-açúcar, soja e cacau, que ocupam espaços geoeconômicos de contornos bem delimitados, grande parte dos produtores exploram culturas alimentícias básicas (arroz, feijão, milho e mandioca). A produção de frutas nos vales úmidos constitui atividade incipiente que apresenta sérios problemas de logística, razão por que possui inexpressiva densidade econômica no conjunto da agricultura cooperativa;

- acesso limitado a serviços especializados - verificou-se que as cooperativas fazem pouco uso de serviços especializados de engenharia financeira, organização empresarial, auditoria externa etc. Acredita-se que esta condição esteja associada a dois principais fatores. Em primeiro lugar, a capacidade financeira da maioria das cooperativas constitui fator impeditivo à contratação de serviços profissionais. É também é escassa a oferta de serviços de qualidade, especialmente, nos municípios distantes de grandes centros urbanos. 
- Fraca relação econômica entre cooperado e cooperativa conforme relatado, apenas $10,5 \%$ da produção oriunda de produtor cooperado do Nordeste são comercializados por intermédio da cooperativa.

A análise de correspondências múltiplas e de classificação a que se procedeu no presente trabalho revelou a existência de três grupos distintos de cooperativas, cujas características principais são remetidas para os Anexos 17, 18 e 19 , a saber:

- cooperativas de difícil recuperação - Este grupo representa $50 \%$ da amostra considerada, sendo constituído de $3 / 5$ de cooperativas que foram fundadas nos anos noventa. Detendo estrutura operacional de pequeno porte ou nenhuma, essas cooperativas dedicam-se predominantemente à administração de créditos de repasse a associados, visto que tais negócios representam $68,8 \%$ dos ativos operacionais, dimensionados em $R \$ 2,54$ milhões, em média. O nível de endividamento alcança $89,3 \%$ dos fundos utilizados. $O$ quadro social é extremamente pequeno: em média, 328 cooperados. Há fortes indícios de que aludidas cooperativas mantêm elevada capacidade instalada ociosa, pois o faturamento agregado delas corresponde apenas a $6,9 \%$ dos ativos totais;

- cooperativas revitalizáveis - constituídas até a década de oitenta, essas cooperativas reúnem considerável patrimônio e exploram, em sua maioria, atividades econômicas deficitárias. O quadro social é composto, em média, por 1.003 cooperados. O nível de endividamento corresponde a $76,9 \%$ dos fundos utilizados, dimensionados em $\mathrm{R} \$ 5,03$ milhões, em média. A proporção de operações de repasse a associados equivale a $50,7 \%$ dos ativos totais. Nota-se, ainda, baixo nível de participação dos associados, 
dado que o volume agregado dos negócios das cooperativas é equivalente a tão-somente $22,6 \%$ dos ativos totais;

- cooperativas potencialmente dinâmicas - representando um quarto da amostra considerada, essas cooperativas possuem maior porte econômico e moderado nível de endividamento, situado em $59,3 \%$ dos fundos totais, dimensionados em $\mathrm{R} \$ 6,45$ milhões, em média. $O$ faturamento agregado dessas cooperativas é equivalente a $84,9 \%$ dos ativos utilizados, revelando certo dinamismo empresarial e relacionamento mais intenso com seus associados. Diferentemente dos grupos precedentes, essas cooperativas, possuem pequena proporção de operações de repasse a associados, correspondendo apenas a $8,4 \%$ de seus ativos totais. Cumpre ainda destacar que $80 \%$ de referidas organizações foram fundadas até a década de oitenta. O quadro social é formado por 877 cooperados, em média, com elevada dispersão, pois o coeficiente de variação é da ordem de 1,54, sugerindo que a performance operacional, possivelmente, independe do número de associados da cooperativa.

\subsection{Recomendações de políticas para o cooperativismo}

Em que pese a existência dos problemas apresentados, o cooperativismo produz externalidades geradoras de melhorias tecnológicas e aumento de eficiência nas explorações conduzidas pelos produtores associados capazes torná-los melhor situados em relação aos demais produtores nordestinos, conforme se nota nos indicadores apresentados na Tabela 49. 
Tabela 49. Comparação entre estabelecimentos agropecuários de produtores cooperados e não-cooperados no Nordeste.

\begin{tabular}{lrrr}
\hline Indicadores selecionados & Cooperado (A) & Não-Cooperado (B) & A/B \\
\hline Renda por estabelecimento & $\mathrm{R} \$ 15.008,72$ & $\mathrm{R} \$ 2.679,68$ & 5,6 \\
Renda por pessoa ocupada & $\mathrm{R} \$ 1.058,48$ & $\mathrm{R} \$ 771,58$ & 1,4 \\
Percentual de área irrigada & $3,06 \%$ & $0,76 \%$ & 4,0 \\
Uso de irrigação & $24,93 \%$ & $4,90 \%$ & 5,1 \\
Uso de assistência técnica & $27,61 \%$ & $4,08 \%$ & 6,8 \\
Uso de trator & $13,89 \%$ & $1,99 \%$ & 7,0 \\
Acesso a financiamento & $13,15 \%$ & $1,38 \%$ & 9,5 \\
Uso de energia elétrica & $50,02 \%$ & $18,99 \%$ & 2,6 \\
\hline
\end{tabular}

Fonte: Censo Agropecuário 1995-1996 do IBGE.

Esta performance mantém politicamente defensável a utilização do cooperativismo como elemento dinamizador do processo de modernização e inserção de maior contingente de produtores no mercado agropecuário.

Contudo, como foi visto nas discussões dos resultados do presente trabalho, o modelo de cooperativas excessivamente diversificadas, de pequeno porte e atuação microrregional é pouco atuante. Portanto, é razoável admitir que entre pulverizar o esforço institucional e o crédito com grande número de cooperativas, por vezes constituídas artificialmente em projetos de baixa repercussão estrutural no setor rural, é preferivel concentrar os esforços na revitalização de grupo selecionado de cooperativas que disponham dos atributos necessários para conduzir empreendimentos econômicos em novas bases empresariais.

Nesse sentido, no plano institucional, sugere-se a animação de agentes públicos e privados, com o desígnio de construir ambiente organizacional favorável à modernização produtiva e empresarial de cooperativas, mediante implementação das políticas gerais e setoriais listadas nos Quadros 13 e 14 . 


\begin{tabular}{|c|c|}
\hline Grupo & Políticas públicas recomendadas para o cooperativismo \\
\hline A & $\begin{array}{l}\text { - Instituição de programa de estímulos à fusão e modernização tecnológica e } \\
\text { organizacional de cooperativas agropecuárias; } \\
\text { - Formulação de programas de apoio à reconversão de atividades } \\
\text { produtivas; } \\
\text { - Restrição de financiamento, com recursos públicos, a cooperativas que } \\
\text { tenham menos de três anos de funcionamento. }\end{array}$ \\
\hline$B$ & $\begin{array}{l}\text { - Regulamentação, por meio de Lei Complementar, do Artigo 146, III, c, da } \\
\text { Constituição da República, que dispõe sobre o tratamento tributário do ato } \\
\text { cooperativo, com vista a ampliar seu escopo; } \\
\text { - Extensão às cooperativas dos institutos da falência e da concordata; } \\
\text { - Tipificação dos crimes de responsabilidade civil e penal aplicáveis aos } \\
\text { administradores de cooperativas; } \\
\text { - Concessão de maior flexibilidade para que as cooperativas possam } \\
\text { remunerar adequadamente os capitais próprios, bem como adotar } \\
\text { programas sistemáticos de restituição do capital aos associados; } \\
\text { - Limitação do endividamento total a } 80 \% \text { dos fundos utilizados pelas } \\
\text { cooperativas. }\end{array}$ \\
\hline $\mathrm{C}$ & $\begin{array}{l}\text { - Estruturação de agência governamental de regulação e fiscalização de } \\
\text { organizações cooperativas; } \\
\text { - Permissão para que cooperativas possam fazer emissão pública de títulos } \\
\text { mobiliários; } \\
\text { - Instituição de linhas de crédito para suprimento de necessidades de capital } \\
\text { de giro e financiamento da comercialização agropecuária; } \\
\text { - Instituição de voto proporcional ao volume das transações caracterizadas } \\
\text { como ato cooperativo; } \\
\text { - Concessão de maior liberdade para que as cooperativas possam realizar } \\
\text { operações com terceiros; } \\
\text { - Estruturação de serviço especializado de auditoria externa e consultoria } \\
\text { empresarial; } \\
\text { Levantamento de censo do cooperativismo em períodos regulares. }\end{array}$ \\
\hline
\end{tabular}

Quadro 13. Políticas públicas recomendadas para o cooperativismo.

Fonte: elaboração do autor. 


\begin{tabular}{|c|c|}
\hline Grupo & Políticas privadas recomendadas para o cooperativismo \\
\hline A & $\begin{array}{l}\text { - Homogeneização do quadro social quanto às atividades econômicas } \\
\text { exploradas; } \\
\text { - Incorporação ou fusão com outras cooperativas; } \\
\text { - Integração com empresas âncoras, notadamente redes de distribuição } \\
\text { varejistas; } \\
\text { - Desinvestimento de ativos desnecessários; } \\
\text { - Negociação da transferência da carteira de repasse para os agentes } \\
\text { financeiros intermediários das operações de repasse. }\end{array}$ \\
\hline B & $\begin{array}{l}\text { - Redução do quadro de associados, mantendo somente os cooperados } \\
\text { atuantes; } \\
\text { - } \quad \text { Focalização dos negócios em atividades mais rentáveis; } \\
\text { - Desativação programada de atividades deficitárias; } \\
\text { - Criação de cooperativas de nova geração; } \\
\text { - Utilização compartilhada, com outras empresas, de unidades centrais de } \\
\text { - Terceirização de atividades de apoio; } \\
\text { - Profissionalização da administração. }\end{array}$ \\
\hline & $\begin{array}{l}\text { - Estruturação de centros de ensino e pesquisa voltados para a formação de } \\
\text { pessoal especializado e elaboração de estudos em áreas de interesse do } \\
\text { cooperativismo; } \\
\text { - Redefinição da política interna de preços, de forma a valorizar os } \\
\text { associados que apresentam maior volume, qualidade e/ou regularidade da } \\
\text { oferta; } \\
\text { - Constituição de empresas não-cooperativas, com vistas a flexibilizar a } \\
\text { captação de recursos de investidores externos e viabilizar a realização de } \\
\text { parcerias institucionais; } \\
\text { - Realização de contratos de participação, a fim de possibilitar novos } \\
\text { padrões de fidelidade e de cooperação; } \\
\text { Conversão para sociedade de capital aberto. }\end{array}$ \\
\hline
\end{tabular}

Quadro 14. Políticas privadas recomendadas para o cooperativismo.

Fonte: elaboração do autor. 
Com vistas a elucidar as principais propostas arroladas, apresenta-se a seguir uma breve exposição de motivos a respeito das medidas menos consensuais, a saber:

- constituição de agência nacional de regulação do sistema cooperativista, com definição legal de funções que permitam acompanhamento e disciplinamento permanentes das atividades e práticas desenvolvidas por cooperativas. Esta medida justifica-se em razão da lacuna jurídica gerada pela falta de regulamentação do Artigo $5^{\circ}$, Inciso XVIII, da Constituição da República. Como conseqüência direta desse vácuo jurídico, foram criadas nos últimos doze anos inúmeras "cooperativas de fachada" sem o devido ordenamento de espaços geoeconômicos. Também não desprezível é o fato de que o Brasil deixou de dispor de informações agregadas sistematizadas sobre 0 cooperativismo, prejudicando 0 planejamento de políticas adequadas para o segmento;

- com a regulamentação, por meio de Lei Complementar, do Artigo 146, III, c, da Constituição da República, que dispõe sobre o tratamento tributário do ato cooperativo, ampliando seu escopo de forma a abranger as operações com terceiros, tem-se a redução da carga tributária incidente sobre as cooperativas. Condição essa que contribui para melhorar a competitividade das cooperativas no que se relaciona a preços;

- a tipificação legal dos crimes de responsabilidade para administradores de cooperativas tem a finalidade de propiciar maiores garantias aos associados e credores contra a ação de dirigentes oportunistas;

- a autorização para que as cooperativas possam fazer emissão pública de títulos mobiliários, sob acompanhamento de órgão 
público regulamentar, tem o objetivo de alavancá-las com custo financeiro menor que o financiamento bancário;

- a extensão às cooperativas dos institutos da falência e da concordata visa a permitir maior segurança aos credores quirografários, favorecendo a captação de recursos financeiros no mercado de capitais;

- estruturação e funcionamento de sistema de auditoria especializada em cooperativismo, para atuação em âmbito estadual e/ou regional, com o objetivo de atuar como instrumento de auxílio às ações de monitoração e controle das cooperativas.

No campo organizacional, acredita-se que o primeiro passo seja iniciar ampla reavaliação conjunta e simultânea dos empreendimentos rurais e agroindustriais conduzidos por cooperativas, com vistas a examinar o estado em que se encontram. A partir do prévio diagnóstico, poderão ser adotadas as seguintes diretrizes, aqui tratadas em dimensões latas, cuja forma de implementação seria ajustada e estruturada aos casos particulares, na oportunidade devida:

- redirecionamento do foco da empresa cooperativa para segmentos de maior retorno econômico, mediante saída programada de atividades que reconhecidamente possam ser supridas por fornecedor externo. A partir de então, poderão as cooperativas reorientar a política de admissão de sócios e os critérios de remuneração dos cooperados, mantendo os produtores que efetivamente estejam dispostos a assumir responsabilidades materialmente definidas quanto à capitalização da empresa cooperativa e utilização dos serviços colocados à disposição; 
- adequação da estrutura patrimonial da cooperativa às reais possibilidades de utilização pelos associados, observados os padrões tecnológicos economicamente viáveis para a realidade local. Esta ação poderá implicar a necessidade de desimobilização de ativos operacionais ociosos ou considerados não essenciais ou, ainda, indicar a possibilidade de fusão ou integração por meio de contrato de parceria com outras empresas em empreendimentos de interesse comum;

- reestruturação da composição das fontes de capitais utilizados pelas cooperativas. A excessiva participação de capitais de terceiros no passivo das cooperativas é insustentável em prazo mediato em função dos custos financeiros envolvidos e da tendência de redução, ainda que disfarçada, de apoio pelos organismos oficiais de crédito. Portanto, além das formas tradicionais de capitalização pelo associado, deve-se buscar a realização de parcerias, com outras cooperativas ou empresas de capital, que permitam a exploração conjunta de atividades correlacionadas ou complementares, mediante compartilhamento de ativos e capitais;

- profissionalização da administração, por intermédio da contratação de gerentes e consultores externos, sempre que exija a complexidade dos processos e operações envolvidos, com o objetivo de permitir melhor gerenciamento do processo de adição de valor aos negócios, de forma que a eficiência empresarial venha efetivamente contribuir para a melhoria das condições econômicas do produtor associado;

- estruturação de instrumentos de monitoração do empreendimento, para que se possam exercer ações de controle e fiscalização de forma operacionalmente consistente pelos associados e, 
subsidiariamente, por órgãos de controle externo (credores, agências de regulação, sistema OCB entre outros);

- por fim, a conversão para sociedade de capital aberto visa a viabilizar novas estratégias de governança financeira pois, a partir de determinado tamanho, as cooperativas têm custos de capital crescentes, conforme demonstrado por Bialoskorski Neto (1998).

As ações sugeridas constituem tentativa de contribuir para o processo reorientação das cooperativas agropecuárias nordestinas. Acredita-se que, com a promoção dos ajustamentos devidos à estrutura orgânica das cooperativas, será possível construir sólidas organizações empresariais que permitam o crescimento ordenado do cooperativismo na região Nordeste.

\subsection{Considerações finais}

O presente trabalho procurou explorar a matéria de forma panorâmica, abrindo caminhos indicativos para a realização de outras pesquisas empíricas de maior profundidade.

Uma grande limitação da pesquisa, relacionada ao estudo da estrutura da agricultura cooperada, deve-se à utilização dos estados da federação, em vez de unidades menores de observação, como as microrregiões homogêneas. Decerto, esta conduta ocultou diferenças internas importantes que carecem de investigação futura. Assim sendo, seria extremamente relevante fazer um zoneamento de âmbito estadual em função dos graus e tipos de modernização da agricultura cooperativa, a partir de dados desagregados por município ou microrregião.

Com referência ao segmento organizacional, o presente trabalho deixou de examinar a situação factual das unidades produtivas filiadas, não alcançando as relações econômicas que os cooperados mantêm fora da 
cooperativa. Não resta dúvida de que é extremamente importante o estudo do cooperativismo a partir do ponto de vista do cooperado, razão por que se deixa como sugestão para pesquisas futuras.

Finalmente, este trabalho abordou a organização cooperativa de forma agregada, deixando como agenda para futuros estudos de caso selecionados os seguintes temas: gerenciamento de sistemas de produção cooperada, desenho organizacional de cooperativas, estruturas de distribuição, engenharia financeira e contratos de parcerias. 
ANEXOS 
Anexo 1. Relação das cooperativas integrantes da amostra.

\begin{tabular}{|c|c|c|c|}
\hline Cooperativa & Município & UF & Atividade principal \\
\hline BATAVO NE & Gerais de Balsas & MA & Comercialização de soja \\
\hline CAIPIG & Alvorada de Gurguéia & $\mathrm{PI}$ & Fruticultura \\
\hline CAMAGIL & Araçagi & PB & Comercialização de castanha \\
\hline CAMAPLA & Angical do Piauí & $\mathrm{Pl}$ & Industrialização de leite \\
\hline CAMIC & Condado & PB & Fruticultura \\
\hline CAMICIL & Cachoeira dos Índios & PB & Comercialização de arroz \\
\hline CAMPAL & Patos & PB & Beneficiamento de algodão \\
\hline CAMPIB & Petrolina & PE & Fruticultura \\
\hline CAMPIC & Juazeiro & BA & Fruticultura \\
\hline CAPI & Morada Nova & CE & Comercialização de arroz \\
\hline CAPIVAB & Limoeiro do Norte & CE & Comercialização de arroz \\
\hline CAPLO & Ouricuri & PE & Repasse de crédito \\
\hline CERVAP & Mossoró & RN & Eletrificação rural \\
\hline CIVAB & Morada nova & CE & Industrialização de arroz \\
\hline COABETA & Betânia & PE & Repasse de crédito \\
\hline COAGRIL & Riachão & MA & Comercialização de arroz \\
\hline COAMIGA & Guarabira & PB & Insumos agropecuários \\
\hline COAPIL & Itaú & RN & Beneficiamento de castanha \\
\hline COCEDRO & Cedro & CE & Beneficiamento de algodão \\
\hline COERBA & Russas & CE & Eletrificação rural \\
\hline colcó & lcó & $\mathrm{CE}$ & Resfriamento de leite \\
\hline COIGUATU & Iguatu & CE & Beneficiamento de arroz \\
\hline COMASIL & Simões & $\mathrm{PI}$ & Insumos agropecuários \\
\hline COOAMI & Chapada Gaúcha & MG & Comercialização de soja \\
\hline COOGOITÁ & Glória do Goitá & PE & Repasse de crédito \\
\hline COOPACAN & Candiba & BA & Industrialização de leite \\
\hline COOPAG & Guanambi & $\mathrm{BA}$ & Industrialização de leite \\
\hline COOPAGRO & Montes Claros & $M G$ & Industrialização de leite \\
\hline COOPAGROL & Grão Mogol & MG & Insumos agropecuários \\
\hline COOPALTO & Pau dos Ferros & RN & Beneficiamento de algodão \\
\hline COOPAMN & Morada Nova & CE & Comercialização de arroz \\
\hline COOPAQUI & Quixadá & CE & Beneficiamento de algodão \\
\hline COOPAR & Russas & $\mathrm{CE}$ & Insumos agropecuários \\
\hline COOPERBAL & Pombal & PB & Beneficiamento de algodão \\
\hline COOPERHORT & Teresina & $\mathrm{Pl}$ & Insumos agropecuários \\
\hline COOPERMIL & Apodi & RN & Beneficiamento de algodão \\
\hline COOPERSANTA & Santa Cruz & PB & Fabricação de açúcar \\
\hline COOPI & Icapuí & CE & Beneficiamento de pescado \\
\hline COOPMOVA & Morada Nova & CE & Insumos agropecuários \\
\hline COOSERRANA & Monte Horebe & PB & Insumos agropecuários \\
\hline FRUCOOP & Janaúba & MG & Comercialização de banana \\
\hline
\end{tabular}

Fonte: dados da pesquisa. 
Anexo 2. Tamanho da cooperativa.

\begin{tabular}{|c|c|c|c|c|c|c|c|}
\hline COOPERATIVA & sócio & EMPREGADO & ATIVO & PATRIMÓNIO & FATURAMENTO & FATOR 1 & MODALIDADE \\
\hline COOPAGRO & 4.448 & 368 & 16.707 & 9.086 & 22.977 & 5,1629 & $T 4$ \\
\hline BATAVO & 47 & 24 & 23.468 & 9.423 & 12.949 & 2,5781 & T4 \\
\hline COOPERMIL & 1.056 & 35 & 7.463 & 1.162 & 3.434 & 0,4176 & T3 \\
\hline COAPIL & 730 & 135 & 4.380 & 1.056 & 1.147 & 0,4049 & T3 \\
\hline CIVAB & 716 & 31 & 5.221 & 2.225 & 4.287 & 0,3937 & Тз \\
\hline COOPALTO & 2.418 & 4 & 5.585 & 1.199 & 1.062 & 0,3835 & T3 \\
\hline COERBA & 300 & 43 & 8.393 & 2.068 & 711 & 0,2892 & T3 \\
\hline CAMPAL & 1.173 & 8 & 4.946 & 1.680 & 3.033 & 0,2545 & T3 \\
\hline CERVAP & 1.651 & 37 & 3.157 & 991 & 1.510 & 0,2048 & T3 \\
\hline COOPAR & 324 & 18 & 9.029 & 2.070 & 590 & 0,1947 & T3 \\
\hline COOPMOVA & 1.502 & 20 & 2.701 & 817 & 1.786 & 0,0777 & T3 \\
\hline COICó & 832 & 34 & 4.341 & 1.223 & 939 & 0,0530 & T3 \\
\hline COOPAG & 1.631 & 17 & 2.280 & 596 & 625 & $-0,0248$ & $\mathrm{~T} 2$ \\
\hline COCEDRO & 998 & 7 & 5.675 & 668 & 168 & $-0,0593$ & $\mathrm{~T} 2$ \\
\hline COOPAMN & 283 & 21 & 3.348 & 927 & 2.939 & $-0,0884$ & $\mathrm{~T} 2$ \\
\hline CAMICIL & 863 & 21 & 3.195 & 646 & 364 & $-0,1551$ & T2 \\
\hline CAIPIG & 187 & 18 & 7.201 & 428 & 105 & $-0,1657$ & T2 \\
\hline COAMIGA & 807 & 12 & 4.214 & 438 & 172 & $-0,1883$ & T2 \\
\hline CAPIVAB & 233 & 16 & 2.678 & 967 & 2.235 & $-0,1924$ & $\mathrm{~T} 2$ \\
\hline COOPACAN & 761 & 16 & 3.865 & 367 & 315 & $-0,2019$ & $\mathrm{~T} 2$ \\
\hline COIGUATU & 358 & 15 & 3.257 & 759 & 1.100 & $-0,2340$ & T2 \\
\hline CAMPIB & 126 & 2 & 3.504 & 660 & 2.331 & $-0,2532$ & T2 \\
\hline COOPAQUI & 415 & 12 & 4.019 & 290 & 443 & $-0,2927$ & T2 \\
\hline CAMAGIL & 598 & 6 & 2.383 & 461 & 239 & $-0,3469$ & T2 \\
\hline CAPI & 200 & 6 & 1.890 & 440 & 1.495 & $-0,3902$ & T2 \\
\hline COOPAGROL & 194 & 7 & 2.908 & 404 & 210 & $-0,4209$ & T2 \\
\hline COMASIL & 132 & 12 & 3.061 & 293 & 190 & $-0,4241$ & T2 \\
\hline COOPI & 128 & 7 & 2.591 & 236 & 485 & $-0,4565$ & T2 \\
\hline COOSERRANA & 408 & 4 & 1.721 & 238 & 177 & $-0,4648$ & $\mathrm{~T}_{2}$ \\
\hline COOPERBAL & 437 & 3 & 1.935 & 159 & 32 & $-0,4698$ & T2 \\
\hline COAGRIL & 43 & 7 & 2.130 & 572 & 217 & $-0,4750$ & T2 \\
\hline CAMPIC & 96 & 7 & 2.478 & 328 & 32 & $-0,4866$ & T2 \\
\hline COOAMI & 429 & 23 & 366 & -92 & 334 & $-0,4883$ & T2 \\
\hline CAPLO & 160 & 3 & 2.170 & 195 & 81 & $-0,5159$ & $\mathrm{T1}$ \\
\hline CAMIC & 103 & 7 & 1.651 & 208 & 216 & $-0,5306$ & T1 \\
\hline FRUCOOP & 41 & 26 & 37 & 4 & 694 & $-0,5511$ & $\mathrm{T1}$ \\
\hline COOPERHORT & 115 & 6 & 867 & 52 & 15 & $-0,6035$ & T1 \\
\hline COOPERSANTA & 105 & 12 & 83 & 11 & 0 & $-0,6292$ & $\mathrm{~T} 1$ \\
\hline COOGOITÁ & 146 & 2 & 318 & 11 & 0 & $-0,6454$ & T1 \\
\hline COABETA & 36 & 3 & 463 & 14 & 0 & $-0,6599$ & $T 1$ \\
\hline
\end{tabular}

Fonte: dados da pesquisa.

Nota: os valores financeiros estão expressos em $R \$$ mil; as variáveis: número de sócios e número de empregados estão expressas em unidades; a coordenada do único fator extraído (Fator 1) é adimensional. 
Anexo 3. Endividamento total da cooperativa.

\begin{tabular}{|c|c|c|c|}
\hline COOPERATIVA & $\begin{array}{c}\text { GRAU DE } \\
\text { ENDIVIDAMENTO }\end{array}$ & RANK & MODALIDADE \\
\hline COOPAGRO & 0,4562 & 1 & E1 \\
\hline CIVAB & 0,5737 & 2 & $\mathrm{E} 1$ \\
\hline BATAVO & 0,5985 & 3 & E1 \\
\hline CAPIVAB & 0,6390 & 4 & $E 1$ \\
\hline CAMPAL & 0,6602 & 5 & E1 \\
\hline CERVAP & 0,6861 & 6 & E1 \\
\hline COOPMOVA & 0,6974 & 7 & $\mathrm{E1}$ \\
\hline COICÓ & 0,7182 & 8 & $\mathrm{E} 2$ \\
\hline COOPAMN & 0,7232 & 9 & E2 \\
\hline COAGRIL & 0,7316 & 10 & E2 \\
\hline COOPAG & 0,7385 & 11 & E2 \\
\hline COERBA & 0,7536 & 12 & E2 \\
\hline COAPIL & 0,7589 & 13 & E2 \\
\hline COIGUATU & 0,7668 & 14 & $\mathrm{E} 2$ \\
\hline CAPI & 0,7672 & 15 & $\mathrm{E} 2$ \\
\hline COOPAR & 0,7707 & 16 & E2 \\
\hline COOPALTO & 0,7853 & 17 & E2 \\
\hline CAMICIL & 0,7978 & 18 & E2 \\
\hline CAMAGIL & 0,8065 & 19 & E2 \\
\hline CAMPIB & 0,8117 & 20 & E2 \\
\hline COOPERMIL & 0,8444 & 21 & E2 \\
\hline COOPAGROL & 0,8610 & 22 & $\mathrm{E} 2$ \\
\hline COOSERRANA & 0,8617 & 23 & E2 \\
\hline CAMPIC & 0,8675 & 24 & $\mathrm{E2}$ \\
\hline COOPERSANTA & 0,8692 & 25 & E2 \\
\hline CAMIC & 0,8743 & 26 & E2 \\
\hline COCEDRO & 0,8824 & 27 & $\mathrm{E} 2$ \\
\hline FRUCOOP & 0,8840 & 28 & E2 \\
\hline COAMIGA & 0,8959 & 29 & $\mathrm{E} 2$ \\
\hline COMASIL & 0,9045 & 30 & E3 \\
\hline COOPACAN & 0,9051 & 31 & E3 \\
\hline COOPI & 0,9090 & 32 & E3 \\
\hline CAPLO & 0,9102 & 33 & E3 \\
\hline COOPERBAL & 0,9180 & 34 & E3 \\
\hline COOPAQUI & 0,9279 & 35 & E3 \\
\hline COOPERHORT & 0,9401 & 36 & E3 \\
\hline CAIPIG & 0,9405 & 37 & E3 \\
\hline COOGOITÁ & 0,9665 & 38 & E3 \\
\hline COABETA & 0,9706 & 39 & E3 \\
\hline COOAMI & 1,2509 & 40 & E3 \\
\hline
\end{tabular}

Fonte: dados da pesquisa. 
Anexo 4. Giro do ativo da cooperativa.

\begin{tabular}{|c|c|c|c|}
\hline COOPERATIVA & GIRO DO ATIVO & RANK & MODALIDADE \\
\hline FRUCOOP & 187,2098 & 1 & N3 \\
\hline COOPAGRO & 137,5324 & 2 & N3 \\
\hline COOAMI & 91,2782 & 3 & N3 \\
\hline COOPAMN & 87,7792 & 4 & N3 \\
\hline CAPIVAB & 83,4569 & 5 & N3 \\
\hline CIVAB & 82,1005 & 6 & N3 \\
\hline CAPI & 79,1254 & 7 & N3 \\
\hline CAMPIB & 66,5316 & 8 & N3 \\
\hline COOPMOVA & 66,1267 & 9 & N3 \\
\hline CAMPAL & 61,3314 & 10 & N3 \\
\hline BATAVO & 55,1782 & 11 & N3 \\
\hline CERVAP & 47,8122 & 12 & N2 \\
\hline COOPERMIL & 46,0129 & 13 & N2 \\
\hline COIGUATU & 33,7595 & 14 & N2 \\
\hline COOPAG & 27,4115 & 15 & N2 \\
\hline COAPIL & 26,1991 & 16 & N2 \\
\hline colcó & 21,6441 & 17 & N2 \\
\hline COOPALTO & 19,0175 & 18 & N2 \\
\hline COOPI & 18,7032 & 19 & N2 \\
\hline CAMIC & 13,0809 & 20 & $\mathrm{~N} 2$ \\
\hline CAMICIL & 11,4119 & 21 & N2 \\
\hline COOPAQUI & 11,0216 & 22 & N2 \\
\hline COOSERRANA & 10,3092 & 23 & N2 \\
\hline COAGRIL & 10,1907 & 24 & N2 \\
\hline CAMAGIL & 10,0135 & 25 & N2 \\
\hline COERBA & 8,4737 & 26 & $\mathrm{~N} 1$ \\
\hline COOPACAN & 8,1471 & 27 & N1 \\
\hline COOPAGROL & 7,2347 & 28 & N1 \\
\hline COOPAR & 6,5293 & 29 & $\mathrm{~N} 1$ \\
\hline COMASIL & 6,1953 & 30 & N1 \\
\hline COAMIGA & 4,0721 & 31 & N1 \\
\hline CAPLO & 3,7536 & 32 & N1 \\
\hline COCEDRO & 2,9515 & 33 & N1 \\
\hline COOPERHORT & 1,7168 & 34 & $\mathrm{~N} 1$ \\
\hline COOPERBAL & 1,6517 & 35 & N1 \\
\hline CAIPIG & 1,4529 & 36 & N1 \\
\hline CAMPIC & 1,2931 & 37 & N1 \\
\hline COOPERSANTA & 0,0000 & 38 & N1 \\
\hline COOGOITÁ & 0,0000 & 39 & N1 \\
\hline COABETA & 0,0000 & 40 & N1 \\
\hline
\end{tabular}

Fonte: dados da pesquisa. 
Anexo 5. Desempenho econômico das cooperativas agropecuárias

\begin{tabular}{|c|c|c|c|c|c|c|}
\hline COOPERATIVA & RAT & RAO & RPL & ML & Fator 1 & MODALIDADE \\
\hline FRUCOOP & 21,53 & 21,53 & 185,63 & 1,15 & 2,3602 & D3 \\
\hline COOPI & 8,19 & 32,69 & 90,00 & 43,79 & 2,3004 & D3 \\
\hline COOPACAN & 4,54 & 24,65 & 47,80 & 55,68 & 1,9201 & D3 \\
\hline CAMPAL & 11,43 & 15,84 & 33,63 & 18,63 & 1,3989 & D3 \\
\hline COMASIL & 0,91 & 4,48 & 9,51 & 14,66 & 0,5542 & D3 \\
\hline COAPIL & 0,34 & 0,65 & 1,42 & 1,31 & 0,2245 & D3 \\
\hline CAPIVAB & 0,41 & 0,53 & 1,13 & 0,49 & 0,2119 & D3 \\
\hline COOPAG & 0,28 & 0,28 & 1,06 & 1,01 & 0,2065 & D3 \\
\hline CERVAP & 0,23 & 0,38 & 0,74 & 0,48 & 0,1994 & D3 \\
\hline COOPERMIL & 0,11 & 0,28 & 0,69 & 0,23 & 0,1887 & D3 \\
\hline COICó & 0,02 & 0,04 & 0,09 & 0,11 & 0,1753 & D3 \\
\hline COOPAMN & 0,03 & 0,04 & 0,11 & 0,03 & 0,1745 & D3 \\
\hline COOPAGROL & 0,01 & 0,03 & 0,05 & 0,09 & 0,1737 & D3 \\
\hline BATAVO & $-0,73$ & $-0,73$ & $-1,82$ & $-1,32$ & 0,1002 & D3 \\
\hline COIGUATU & $-0,65$ & $-1,36$ & $-2,78$ & $-1,92$ & 0,0744 & D3 \\
\hline CAPI & $-1,16$ & $-1,75$ & $-4,98$ & $-1,46$ & 0,0418 & D3 \\
\hline COOPAGRO & $-1,74$ & $-1,77$ & $-3,21$ & $-1,27$ & 0,0300 & D3 \\
\hline COOPMOVA & $-1,33$ & $-2,00$ & $-4,41$ & $-2,02$ & 0,0240 & D3 \\
\hline CIVAB & $-1,81$ & $-1,81$ & $-4,26$ & $-2,21$ & 0,0096 & D3 \\
\hline COAMIGA & $-0,33$ & $-2,93$ & $-3,18$ & $-8,13$ & $-0,0373$ & D2 \\
\hline COOPAR & $-1,01$ & $-2,61$ & $-4,42$ & $-15,51$ & $-0,1537$ & $\mathrm{D} 2$ \\
\hline CAMICIL & $-1,54$ & $-4,41$ & $-7,63$ & $-13,51$ & $-0,2096$ & D2 \\
\hline COOPALTO & $-2,59$ & $-5,56$ & $-12,07$ & $-13,63$ & $-0,2996$ & D2 \\
\hline COERBA & $-2,38$ & $-4,27$ & $-9,65$ & $-28,05$ & $-0,4319$ & D2 \\
\hline COCEDRO & $-1,09$ & $-6,19$ & $-9,24$ & $-36,82$ & $-0,5466$ & $\mathrm{D} 2$ \\
\hline COOSERRANA & $-2,55$ & $-14,30$ & $-18,45$ & $-24,75$ & $-0,7026$ & D2 \\
\hline CAMIC & $-4,15$ & $-9,74$ & $-33,00$ & $-31,72$ & $-0,7922$ & D2 \\
\hline CAMPIB & $-9,10$ & $-11,94$ & $-48,33$ & $-13,68$ & $-0,8673$ & D2 \\
\hline CAMAGIL & $-4,03$ & $-14,48$ & $-20,84$ & $-40,27$ & $-0,9710$ & $\mathrm{D} 2$ \\
\hline COAGRIL & $-5,74$ & $-10,26$ & $-21,37$ & $-56,29$ & $-1,1284$ & D2 \\
\hline COOAMI & $-32,99$ & $-32,99$ & 131,50 & $-36,14$ & $-1,8069$ & D2 \\
\hline COOPAQUI & $-7,83$ & $-34,40$ & $-108,56$ & $-71,06$ & $-2,4238$ & D2 \\
\hline CAIPIG & - & - & - & - & - & D1 \\
\hline CAPLO & - & - & - & - & - & D1 \\
\hline CAMPIC & - & - & - & - & - & D1 \\
\hline COOPERBAL & - & - & - & - & - & D1 \\
\hline COOPERHORT & - & - & - & - & - & D1 \\
\hline COOGOITÁ & - & - & - & - & - & D1 \\
\hline COABETA & - & - & - & - & - & D1 \\
\hline COOPERSANTA & - & - & - & - & - & D1 \\
\hline
\end{tabular}

Fonte: dados da pesquisa.

Nota: os valores financeiros estāo expressos em proporções; a coordenada do único fator extraído (Fator 1) é adimensional. 
Anexo 6. Data de fundação da cooperativa.

\begin{tabular}{|c|c|c|}
\hline COOPERATIVA & DATA DE FUNDAÇÃO & MODALIDADE \\
\hline COAMIGA & $28 / 04 / 1939$ & $\mathrm{~F} 1$ \\
\hline CAMPAL & $03 / 05 / 1951$ & $\mathrm{~F} 1$ \\
\hline COOPAGRO & $23 / 10 / 1954$ & $\mathrm{~F} 1$ \\
\hline COOPMOVA & $20 / 05 / 1956$ & $\mathrm{~F} 1$ \\
\hline COOPAQUI & $07 / 06 / 1959$ & $\mathrm{~F} 1$ \\
\hline COCEDRO & $01 / 05 / 1960$ & $\mathrm{~F} 1$ \\
\hline COICÓ & $05 / 06 / 1960$ & $\mathrm{~F} 1$ \\
\hline COOPERBAL & $14 / 11 / 1964$ & $\mathrm{~F} 1$ \\
\hline COOPERMIL & $02 / 09 / 1967$ & $\mathrm{~F} 1$ \\
\hline COAPIL & $28 / 09 / 1968$ & $\mathrm{~F} 1$ \\
\hline CERVAP & $22 / 11 / 1969$ & $\mathrm{~F} 1$ \\
\hline COOPAG & $24 / 10 / 1970$ & $\mathrm{~F} 1$ \\
\hline CIVAB & $22 / 03 / 1972$ & $\mathrm{~F} 1$ \\
\hline COERBA & 05/05/1973 & $\mathrm{F} 1$ \\
\hline CAMIC & $15 / 06 / 1975$ & $\mathrm{~F} 1$ \\
\hline COIGUATU & $29 / 01 / 1977$ & $\mathrm{~F} 1$ \\
\hline COOPALTO & 22/03/1980 & $\mathrm{F} 1$ \\
\hline CAIPIG & $24 / 05 / 1983$ & $\mathrm{~F} 1$ \\
\hline COOPAR & $28 / 06 / 1984$ & $\mathrm{~F} 1$ \\
\hline COOPACAN & $18 / 05 / 1986$ & $\mathrm{~F} 1$ \\
\hline CAMPIB & 28/01/1987 & $\mathrm{F} 1$ \\
\hline CAMPIC & $18 / 04 / 1987$ & $\mathrm{~F} 1$ \\
\hline CAMAGIL & $27 / 08 / 1987$ & $\mathrm{~F} 1$ \\
\hline CAPI & $14 / 10 / 1987$ & $\mathrm{~F} 1$ \\
\hline COOPAMN & $14 / 10 / 1987$ & F1 \\
\hline CAPIVAB & $15 / 10 / 1987$ & $\mathrm{~F} 1$ \\
\hline COOSERRANA & 24/04/1993 & $\mathrm{F} 2$ \\
\hline COAGRIL & $22 / 05 / 1993$ & F2 \\
\hline COOPI & 29/05/1993 & $\mathrm{F} 2$ \\
\hline COOPAGROL & $11 / 06 / 1993$ & $\mathrm{~F} 2$ \\
\hline COOPERHORT & $11 / 07 / 1993$ & $\mathrm{~F} 2$ \\
\hline CAPLO & $14 / 01 / 1994$ & $\mathrm{~F} 2$ \\
\hline COOPERSANTA & 05/03/1994 & F2 \\
\hline BATAVO & $09 / 05 / 1995$ & $\mathrm{~F} 2$ \\
\hline COMASIL & 09/03/1996 & $\mathrm{F} 2$ \\
\hline FRUCOOP & 18/04/1996 & $\mathrm{F} 2$ \\
\hline COABETA & $30 / 04 / 1996$ & $\mathrm{~F} 2$ \\
\hline COOGOITÁ & $22 / 05 / 1996$ & $\mathrm{~F} 2$ \\
\hline COOAMI & $22 / 01 / 1997$ & F2 \\
\hline CAMICIL & $26 / 02 / 1997$ & F2 \\
\hline
\end{tabular}

Fonte: dados da pesquisa. 
Anexo 7. Grau de relacionamento institucional da cooperativa.

\begin{tabular}{|c|c|c|c|}
\hline COOPERATIVA & ESCORE & RANK & MODALIDADE \\
\hline BATAVO & 54 & 1 & 12 \\
\hline COOPAGRO & 50 & 2 & 12 \\
\hline CIVAB & 48 & 3 & 12 \\
\hline CAMPIC & 47 & 4 & 12 \\
\hline COOPAG & 47 & 5 & 12 \\
\hline CERVAP & 46 & 6 & 12 \\
\hline COOPMOVA & 44 & 7 & 12 \\
\hline CAPI & 44 & 8 & 12 \\
\hline COOIGUATU & 44 & 9 & 12 \\
\hline COOAMI & 44 & 10 & 12 \\
\hline COOPAMN & 43 & 11 & 12 \\
\hline COOPAR & 43 & 12 & 12 \\
\hline COAPIL & 43 & 13 & 12 \\
\hline CAPIVAB & 41 & 14 & 12 \\
\hline COOPERMIL & 40 & 15 & 12 \\
\hline FRUCOOP & 40 & 16 & 12 \\
\hline CAMICIL & 39 & 17 & 12 \\
\hline COOPAQUI & 38 & 18 & 12 \\
\hline CAMAGIL & 38 & 19 & 12 \\
\hline CAMPIB & 38 & 20 & 12 \\
\hline colcó & 37 & 21 & 11 \\
\hline CAMIC & 37 & 22 & 11 \\
\hline COOPERBAL & 36 & 23 & 11 \\
\hline COERBA & 35 & 24 & 11 \\
\hline CAMPAL & 35 & 25 & 11 \\
\hline COCEDRO & 32 & 26 & 11 \\
\hline COOPACAN & 32 & 27 & 11 \\
\hline COOPI & 31 & 28 & 11 \\
\hline COAMIGA & 31 & 29 & 11 \\
\hline CAPLO & 31 & 30 & 11 \\
\hline COOPERSANTA & 30 & 31 & 11 \\
\hline COAGRIL & 29 & 32 & 11 \\
\hline COOPERHORT & 29 & 33 & 11 \\
\hline COOPAGROL & 29 & 34 & 11 \\
\hline COMASIL & 28 & 35 & 11 \\
\hline COABETA & 28 & 36 & 11 \\
\hline CAIPIG & 27 & 37 & 11 \\
\hline COOSERRANA & 27 & 38 & 11 \\
\hline COOPALTO & 25 & 39 & 11 \\
\hline COOGOITÁ & 23 & 40 & 11 \\
\hline
\end{tabular}

Fonte: dados da pesquisa. 
Anexo 8. Intensidade de uso de práticas administrativas nas cooperativas.

\begin{tabular}{|c|c|c|c|}
\hline COOPERATIVA & ESCORE & RANK & MODALIDADE \\
\hline BATAVO & 13 & 1 & $\mathrm{R} 2$ \\
\hline COOPAGRO & 12 & 2 & $\mathrm{R} 2$ \\
\hline CAPI & 11 & 3 & $\mathrm{R} 2$ \\
\hline CIVAB & 10 & 4 & $\mathrm{R} 2$ \\
\hline COICó & 10 & 5 & $\mathrm{R} 2$ \\
\hline COOPERMIL & 10 & 6 & $\mathrm{R} 2$ \\
\hline COOPMOVA & 10 & 7 & $\mathrm{R} 2$ \\
\hline CERVAP & 9 & 8 & $\mathrm{R} 2$ \\
\hline COAPIL & 9 & 9 & $\mathrm{R} 2$ \\
\hline COIGUATU & 9 & 10 & $\mathrm{R} 2$ \\
\hline COOAMI & 9 & 11 & $\mathrm{R} 2$ \\
\hline CAMPIB & 8 & 12 & $\mathrm{R} 2$ \\
\hline COERBA & 8 & 13 & $\mathrm{R} 2$ \\
\hline COOPAR & 8 & 14 & $\mathrm{R} 2$ \\
\hline FRUCOOP & 7 & 15 & $\mathrm{R} 2$ \\
\hline CAMAGIL & 6 & 16 & $\mathrm{R} 2$ \\
\hline CAMPAL & 6 & 17 & $\mathrm{R} 2$ \\
\hline CAPIVAB & 6 & 18 & $\mathrm{R} 2$ \\
\hline COOPAMN & 5 & 19 & $\mathrm{R} 2$ \\
\hline COOPI & 5 & 20 & $\mathrm{R} 2$ \\
\hline CAMPIC & 4 & 21 & R1 \\
\hline COOPACAN & 4 & 22 & $\mathrm{R} 1$ \\
\hline CAIPIG & 3 & 23 & R1 \\
\hline COCEDRO & 3 & 24 & R1 \\
\hline COOPERSANTA & 3 & 25 & R1 \\
\hline COOSERRANA & 3 & 26 & R1 \\
\hline COAGRIL & 2 & 27 & $\mathrm{R} 1$ \\
\hline COAMIGA & 2 & 28 & R1 \\
\hline COMASIL & 2 & 29 & R1 \\
\hline COOPAG & 2 & 30 & R1 \\
\hline COOPAQUI & 2 & 31 & R1 \\
\hline COOPERHORT & 2 & 32 & R1 \\
\hline CAMICIL & 1 & 33 & $\mathrm{R} 1$ \\
\hline COABETA & 1 & 34 & R1 \\
\hline COOPALTO & 1 & 35 & R1 \\
\hline COOPERBAL & 1 & 36 & R1 \\
\hline CAMIC & 0 & 37 & $\mathrm{R} 1$ \\
\hline CAPLO & 0 & 38 & R1 \\
\hline COOGOITÁ & 0 & 39 & $\mathrm{R} 1$ \\
\hline COOPAGROL & 0 & 40 & R1 \\
\hline
\end{tabular}

Fonte: dados da pesquisa. 
Anexo 9. Grau de escolaridade dos dirigentes da cooperativa.

\begin{tabular}{|c|c|c|c|c|c|}
\hline COOPERATIVA & FUNDAMENTAL & BÁSICO & SUPERIOR & ESCORE & MODALIDADE \\
\hline COERBA & 0 & 1 & 2 & 5,00 & 23 \\
\hline COAPIL & 0 & 2 & 3 & 4,80 & $\mathrm{Z3}$ \\
\hline COOPAGRO & 0 & 2 & 2 & 4,50 & $\mathrm{Z3}$ \\
\hline COOPERMIL & 0 & 3 & 2 & 4,20 & $\mathrm{Z3}$ \\
\hline BATAVO & 0 & 2 & 1 & 4,00 & Z3 \\
\hline COOPAG & 0 & 2 & 1 & 4,00 & $\mathrm{Z3}$ \\
\hline COOPAR & 2 & 1 & 3 & 3,83 & $\mathrm{Z3}$ \\
\hline FRUCOOP & 0 & 7 & 2 & 3,67 & $\mathrm{Z3}$ \\
\hline COOPALTO & 0 & 4 & 1 & 3,60 & $\mathrm{Z3}$ \\
\hline CERVAP & 2 & 0 & 2 & 3,50 & $\mathrm{Z3}$ \\
\hline COOPMOVA & 2 & 1 & 2 & 3,40 & Z3 \\
\hline COIGUATU & 2 & 1 & 2 & 3,40 & $\mathrm{Z3}$ \\
\hline COOPI & 0 & 5 & 0 & 3,00 & $\mathrm{Z2}$ \\
\hline COOPACAN & 0 & 3 & 0 & 3,00 & $\mathrm{Z2}$ \\
\hline CAMPAL & 2 & 5 & 1 & 2,88 & $\mathrm{Z2}$ \\
\hline COOPERBAL & 2 & 2 & 1 & 2,80 & $\mathrm{Z2}$ \\
\hline CAMICIL & 3 & 1 & 1 & 2,40 & $\mathrm{Z2}$ \\
\hline COOAMI & 3 & 1 & 1 & 2,40 & $\mathrm{Z2}$ \\
\hline COOPAQUI & 2 & 4 & 0 & 2,33 & $\mathrm{Z2}$ \\
\hline COCEDRO & 2 & 3 & 0 & 2,20 & $\mathrm{Z2}$ \\
\hline COOPERHORT & 4 & 1 & 1 & 2,17 & $\mathrm{Z2}$ \\
\hline colcó & 4 & 1 & 1 & 2,17 & $\mathrm{Z2}$ \\
\hline COOSERRANA & 4 & 1 & 1 & 2,17 & $\mathrm{Z2}$ \\
\hline COMASIL & 6 & 3 & 0 & 1,67 & $\mathrm{Z2}$ \\
\hline COOPAGROL & 5 & 2 & 0 & 1,57 & $\mathrm{Z2}$ \\
\hline COOPERSANTA & 8 & 0 & 1 & 1,56 & $Z 2$ \\
\hline COABETA & 4 & 1 & 0 & 1,40 & $\mathrm{Z2}$ \\
\hline CIVAB & 5 & 1 & 0 & 1,33 & $\mathrm{Z2}$ \\
\hline COOPAMN & 5 & 1 & 0 & 1,33 & $\mathrm{Z2}$ \\
\hline CAPIVAB & 6 & 1 & 0 & 1,29 & $\mathrm{Z2}$ \\
\hline CAPLO & 6 & 1 & 0 & 1,29 & $\mathrm{Z2}$ \\
\hline COAGRIL & 6 & 0 & 0 & 1,00 & $\mathrm{Z1}$ \\
\hline CAIPIG & 5 & 0 & 0 & 1,00 & $\mathrm{Z1}$ \\
\hline CAPI & 7 & 0 & 0 & 1,00 & $\mathrm{Z1}$ \\
\hline CAMAGIL & 6 & 0 & 0 & 1,00 & $\mathrm{Z1}$ \\
\hline COAMIGA & 6 & 0 & 0 & 1,00 & $\mathrm{Z1}$ \\
\hline CAMIC & 5 & 0 & 0 & 1,00 & $\mathrm{Zl}$ \\
\hline CAMPIB & 7 & 0 & 0 & 1,00 & $\mathrm{Z} 1$ \\
\hline COOGOITÁ & 6 & 0 & 0 & 1,00 & $\mathrm{Z1}$ \\
\hline CAMPIC & 6 & 0 & 0 & 1,00 & $\mathrm{Z1}$ \\
\hline
\end{tabular}

Fonte: dados da pesquisa. 
Anexo 10. Variáveis descritivas de desenvolvimento agrícola.

\begin{tabular}{|c|c|c|c|c|c|c|c|c|c|c|c|c|c|c|}
\hline UF & VPES & CONT & TRAT & ASTC & PERM & VPHA & VPPO & ADMI & FINA & ATTO & COOP & FAML & ENER & FERT \\
\hline$A C$ & 6.396 & 12,8 & 1,5 & 22,6 & 5,0 & 33 & 1.540 & 7,5 & 4,1 & 21,7 & 4,4 & 87,2 & 18,3 & 3,4 \\
\hline AL & 46.728 & 68,0 & 10,2 & 36,0 & 29,4 & 514 & 5.012 & 12,3 & 10,3 & 66,4 & 4,8 & 32,0 & 33,1 & 56,9 \\
\hline AM & 7.727 & 10,7 & 1,2 & 45,0 & 3,4 & 80 & 1.669 & 2,9 & 13,1 & 8,3 & 1,6 & 89,3 & 13,8 & 30,5 \\
\hline AP & 19.124 & 24,8 & 2,1 & 26,0 & 10,2 & 263 & 4.948 & 5,2 & 1,0 & 11,2 & 2,9 & 75,2 & 40,6 & 55,2 \\
\hline BA & 16.060 & 51,3 & 13,3 & 39,8 & 27,9 & 88 & 2.903 & 20,2 & 10,8 & 41,7 & 2,0 & 48,7 & 35,8 & 44,1 \\
\hline CE & 9.138 & 43,2 & 5,3 & 25,6 & 10,1 & 138 & 1.865 & 6,4 & 18,4 & 20,2 & 4,0 & 56,8 & 60,0 & 42,9 \\
\hline DF & 73.057 & 66,3 & 67,1 & 93,6 & 42,2 & 512 & 11.150 & 21,3 & 24,9 & 60,6 & 17,2 & 33,7 & 98,3 & 96,0 \\
\hline ES & 23.645 & 59,5 & 24,0 & 40,6 & 21,0 & 259 & 3.587 & 4,8 & 7,9 & 62,5 & 16,0 & 40,5 & 88,0 & 76,0 \\
\hline GO & 51.711 & 56,4 & 41,2 & 52,1 & 33,9 & 145 & 10.356 & 0,8 & 14,5 & 68,1 & 18,0 & 43,6 & 87,4 & 65,8 \\
\hline MA & 14.465 & 42,6 & 12,6 & 30,9 & 11,4 & 75 & 2.711 & 8,9 & 14,4 & 47,6 & 0,7 & 57,4 & 28,9 & 29,7 \\
\hline MG & 30.945 & 59,3 & 29,7 & 56,5 & 30,7 & 204 & 5.882 & 12,2 & 8,5 & 50,1 & 21,5 & 40,7 & 80,1 & 80,7 \\
\hline MS & 70.269 & 56,4 & 60,7 & 58,6 & 39,9 & 111 & 14.832 & 12,3 & 19,3 & 72,8 & 18,8 & 43,6 & 78,3 & 55,5 \\
\hline MT & 51.448 & 42,4 & 33,6 & 40,7 & 23,8 & 80 & 10.434 & 11,4 & 17,3 & 49,5 & 10,3 & 57,6 & 51,6 & 31,6 \\
\hline PA & 10.703 & 30,1 & 6,4 & 23,2 & 10,2 & 40 & 1.933 & 6,8 & 30,1 & 24,4 & 2,9 & 69,9 & 14,0 & 30,4 \\
\hline PB & 8.387 & 42,3 & 6,9 & 21,8 & 13,9 & 109 & 1.782 & 6,0 & 15,0 & 18,8 & 5,2 & 57,7 & 59,9 & 44,6 \\
\hline PE & 18.950 & 51,2 & 6,3 & 21,0 & 21,0 & 356 & 3.227 & 6,8 & 8,3 & 41,2 & 2,7 & 48,8 & 67,5 & 48,1 \\
\hline PI & 8.214 & 22,9 & 5,1 & 16,8 & 8,0 & 69 & 2.170 & 4,2 & 10,5 & 12,9 & 1,9 & 77,1 & 30,7 & 20,8 \\
\hline PR & 28.801 & 33,2 & 43,7 & 73,0 & 15,4 & 467 & 7.194 & 5,9 & 27,6 & 77,6 & 26,9 & 66,8 & 75,8 & 87,6 \\
\hline RJ & 15.812 & 52,7 & 17,1 & 56,2 & 33,7 & 183 & 3.946 & 4,4 & 2,9 & 39,8 & 27,6 & 47,3 & 73,4 & 53,4 \\
\hline RN & 21.864 & 43,5 & 19,9 & 18,3 & 14,8 & 184 & 1.775 & 6,8 & 11,4 & 15,1 & 10,3 & 56,5 & 61,4 & 38,1 \\
\hline RO & 5.585 & 17,1 & 4,0 & 28,9 & 5,4 & 47 & 1.163 & 4,2 & 11,3 & 37,5 & 5,8 & 82,9 & 35,7 & 14,6 \\
\hline $\mathrm{RR}$ & 8.008 & 20,9 & 6,6 & 26,4 . & 7,8 & 28 & 2.003 & 8,7 & 23,3 & 15,4 & 5,7 & 79,1 & 19,3 & 27,1 \\
\hline RS & 18.504 & 15,2 & 34,5 & 60,7 & 8,3 & 307 & 5.437 & 2,4 & 25,2 & 40,3 & 47,0 & 84,8 & 82,9 & 90,8 \\
\hline SC & 21.147 & 12,9 & 31,9 & 75,8 & 4,8 & 696 & 5.511 & 1,6 & 33,3 & 51,4 & 35,1 & 87,1 & 94,5 & 94,1 \\
\hline SE & 12.080 & 34,5 & 6,8 & 46,0 & 11,5 & 506 & 2.654 & 5,6 & 24,4 & 58,0 & 1,7 & 65,5 & 38,7 & 77,0 \\
\hline SP & 67.367 & 66,0 & 57,8 & 70,6 & 50,3 & 523 & 11.922 & 16,3 & 14,8 & 78,6 & 30,5 & 34,0 & 80,8 & 82,6 \\
\hline TO & 23.869 & 49,4 & 33,1 & 36,3 & 24,6 & 37 & 4.218 & 1,5 & 19,4 & 44,0 & 3,0 & 50,6 & 31,5 & 40,0 \\
\hline
\end{tabular}

Fonte: Censo Agropecuário de 1995-96 do IBGE.

Notas: As variáveis VPES, VPHA e VPPO estão expressas em R\$; As demais representam proporções em percentual. 
Anexo 11. Coordenadas das Unidades da Federação nos eixos fatoriais.

\begin{tabular}{|c|c|c|c|}
\hline Unidade da Federação & Fator 1 & Fator 2 & Fator 3 \\
\hline Acre & $-1,3363$ & $-0,7581$ & 0,0743 \\
\hline Alagoas & 0,0167 & 1,0129 & $-1,2392$ \\
\hline Amazonas & $-0,9052$ & $-1,1538$ & 0,6388 \\
\hline Amapá & $-0,1955$ & $-0,7171$ & $-0,8763$ \\
\hline Bahia & $-1,0579$ & 0,9328 & $-0,3700$ \\
\hline Ceará & $-0,2975$ & $-0,4720$ & $-0,5780$ \\
\hline Distrito Federal & 0,8291 & 2,0299 & 1,1956 \\
\hline Espirito Santo & 1,1015 & 0,0090 & $-1,7194$ \\
\hline Goiás & 0,6971 & 0,7672 & $-0,1692$ \\
\hline Maranhão & $-0,9311$ & 0,0985 & $-0,0987$ \\
\hline Minas Gerais & 0,7263 & 0,6489 & $-0,9674$ \\
\hline Mato Grosso do Sul & $-0,2238$ & 1,9885 & 1,4408 \\
\hline Mato Grosso & $-0,9192$ & 1,0780 & 1,1696 \\
\hline Pará & $-1,2790$ & $-0,4035$ & 1,1339 \\
\hline Paraíba & $-0,2814$ & $-0,4542$ & $-0,8154$ \\
\hline Pernambuco & 0,2012 & $-0,0726$ & $-1,6311$ \\
\hline Piauí & $-0,9859$ & $-0,7542$ & $-0,1499$ \\
\hline Paraná & 1,4128 & $-0,3410$ & 1,2024 \\
\hline Rio de Janeiro & 0,8583 & $-0,0518$ & $-1,6204$ \\
\hline Rio Grande do Norte & $-0,2285$ & $-0,2560$ & $-0,8440$ \\
\hline Rondônia & $-0,7969$ & $-0,8970$ & 0,1405 \\
\hline Roraima & $-1,2676$ & $-0,5857$ & 1,0683 \\
\hline Rio Grande do Sul & 1,7055 & $-1,4295$ & 1,1389 \\
\hline Santa Catarina & 2,2622 & $-1,6757$ & 1,4310 \\
\hline Sergipe & 0,5152 & $-0,7135$ & 0,0508 \\
\hline São Paulo & 1,0128 & 1,8642 & 0,2448 \\
\hline Tocantins & $-0,6327$ & 0,3059 & 0,1494 \\
\hline
\end{tabular}

Fonte: dados da pesquisa. 


\section{Anexo 12. Partição das classes e distância euclidiana das Unidades} da Federação ao baricentro do grupo.

\begin{tabular}{|c|c|c|c|}
\hline Região & Unidade da Federação & Macroregião & Distância \\
\hline 1 & $\begin{array}{l}\text { Rio de Janeiro } \\
\text { Espírito Santo } \\
\text { Goiás } \\
\text { Minas Gerais } \\
\text { Mato Grosso }\end{array}$ & $\begin{array}{l}\text { Sudeste } \\
\text { Sudeste } \\
\text { Centro-Oeste } \\
\text { Sudeste } \\
\text { Centro-Oeste }\end{array}$ & $\begin{array}{l}0,589 \\
0,453 \\
0,618 \\
0,402 \\
0,708\end{array}$ \\
\hline 2 & $\begin{array}{l}\text { Alagoas } \\
\text { Rio Grande do Norte } \\
\text { Sergipe } \\
\text { Bahia } \\
\text { Ceará } \\
\text { Maranhão } \\
\text { Paraíba } \\
\text { Pernambuco } \\
\text { Tocantins } \\
\end{array}$ & $\begin{array}{l}\text { Nordeste } \\
\text { Nordeste } \\
\text { Nordeste } \\
\text { Nordeste } \\
\text { Nordeste } \\
\text { Nordeste } \\
\text { Nordeste } \\
\text { Nordeste } \\
\text { Norte } \\
\end{array}$ & $\begin{array}{l}0,756 \\
0,415 \\
0,773 \\
0,734 \\
0,342 \\
0,363 \\
0,342 \\
0,449 \\
0,584 \\
\end{array}$ \\
\hline 3 & $\begin{array}{l}\text { Distrito Federal } \\
\text { Mato Grosso do Sul } \\
\text { São Paulo }\end{array}$ & $\begin{array}{l}\text { Centro-Oeste } \\
\text { Centro-Oeste } \\
\text { Sudeste }\end{array}$ & $\begin{array}{l}0,530 \\
0,589 \\
0,373 \\
\end{array}$ \\
\hline 4 & $\begin{array}{l}\text { Acre } \\
\text { Amazonas } \\
\text { Amapá } \\
\text { Pará } \\
\text { Rondônia } \\
\text { Roraima } \\
\text { Piauí }\end{array}$ & $\begin{array}{l}\text { Norte } \\
\text { Norte } \\
\text { Norte } \\
\text { Norte } \\
\text { Norte } \\
\text { Norte } \\
\text { Nordeste }\end{array}$ & $\begin{array}{l}0,438 \\
0,392 \\
0,644 \\
0,605 \\
0,326 \\
0,373 \\
0,223\end{array}$ \\
\hline 5 & $\begin{array}{l}\text { Paraná } \\
\text { Rio Grande do Sul } \\
\text { Santa Catarina }\end{array}$ & $\begin{array}{l}\text { Sul } \\
\text { Sul } \\
\text { Sul }\end{array}$ & $\begin{array}{l}0,497 \\
0,453 \\
0,415\end{array}$ \\
\hline
\end{tabular}

Fonte: dados da pesquisa. 


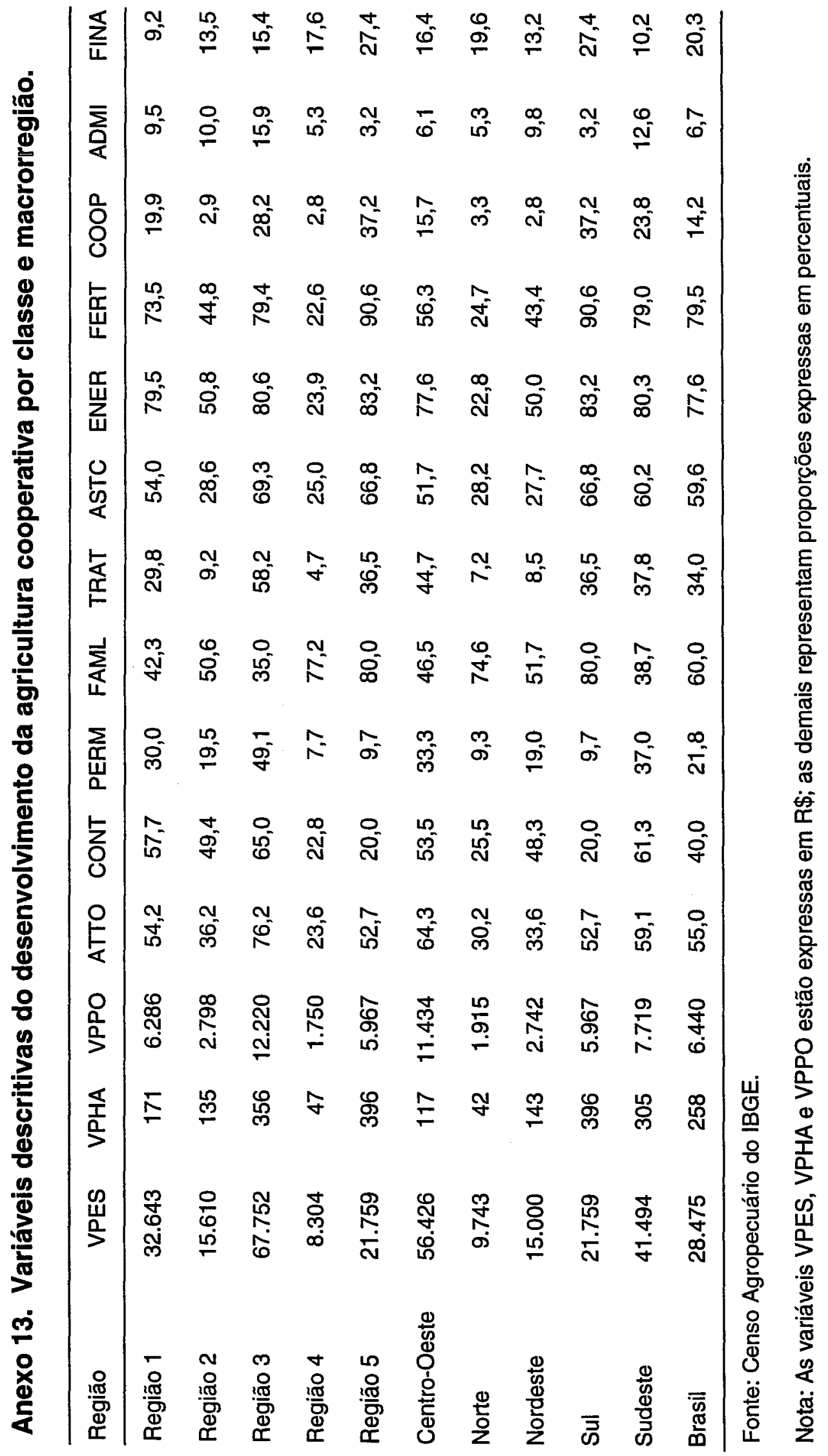


Anexo 14. Matriz disjuntiva completa.

\begin{tabular}{|c|c|c|c|c|c|c|c|c|c|c|c|c|c|c|c|c|c|c|c|c|c|c|}
\hline Cooperativa & 11 & N2 & N3 & T1 & T2 & T3 & T4 & F1 & F2 & 11 & 12 & D1 & D2 & D3 & E1 & E2 & E3 & $\mathrm{R} 1$ & $\mathrm{R} 2$ & Z1 & $\mathrm{Z2}$ & Z3 \\
\hline Batavo & & 0 & 1 & 0 & 0 & 0 & 1 & 0 & 1 & 0 & 1 & 0 & 0 & 1 & 1 & 0 & 0 & 0 & 1 & 0 & 0 & 1 \\
\hline ipig & & 0 & 0 & 0 & 1 & 0 & 0 & 1 & 0 & 1 & 0 & 1 & 0 & 0 & 0 & 0 & 1 & & 0 & 1 & 0 & 0 \\
\hline magil & 0 & 1 & c & 0 & 1 & 0 & 0 & 1 & 0 & 0 & 1 & 0 & 1 & 0 & 0 & 1 & 0 & 0 & 1 & 1 & 0 & 0 \\
\hline mic & 0 & 1 & 0 & 1 & 0 & 0 & 0 & 1 & 0 & 1 & 0 & 0 & 1 & 0 & 0 & 1 & 0 & 1 & 0 & 1 & 0 & 0 \\
\hline micil & 0 & 1 & 0 & 0 & 1 & 0 & 0 & 0 & 1 & 0 & 1 & 0 & 1 & 0 & 0 & 1 & 0 & 1 & 0 & 0 & 1 & 0 \\
\hline al & 0 & 0 & 1 & 0 & 0 & 1 & 0 & 1 & 0 & 1 & 0 & 0 & 0 & 1 & 1 & 0 & 0 & 0 & 1 & 0 & 1 & 0 \\
\hline & 0 & 0 & 1 & 0 & 1 & 0 & 0 & 1 & 0 & 0 & 1 & 0 & 1 & 0 & 0 & 1 & 0 & 0 & 1 & 1 & 0 & 0 \\
\hline npic & 1 & 0 & 0 & 0 & 1 & c & 0 & 1 & 0 & 0 & 1 & 1 & 0 & 0 & 0 & 1 & 0 & & 0 & 1 & 0 & 0 \\
\hline & 0 & 0 & 1 & c & 1 & c & 0 & 1 & 0 & 0 & 1 & 0 & 0 & 1 & 0 & 1 & 0 & & 1 & 1 & 0 & 0 \\
\hline ive & 0 & 0 & 1 & 0 & 1 & $c$ & 0 & 1 & 0 & 0 & 1 & 0 & 0 & 1 & & 0 & 0 & 0 & 1 & 0 & & 0 \\
\hline & 1 & c & c & 1 & 0 & $c$ & 0 & 0 & 1 & 1 & 0 & 1 & 0 & c & & 0 & 1 & & & 0 & & 0 \\
\hline & 0 & 1 & c & 0 & 0 & 1 & 0 & 1 & 0 & 0 & 1 & c & 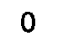 & & & 0 & & & & 0 & 0 & \\
\hline & 0 & 0 & 1 & 0 & 0 & 1 & 0 & 1 & 0 & 0 & 1 & c & 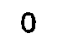 & & & 0 & & & & 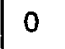 & & 0 \\
\hline & 1 & c & 0 & 1 & 0 & $c$ & 0 & 0 & 1 & 1 & 0 & & c & & & 0 & & & & 0 & & 0 \\
\hline & 0 & 1 & c & 0 & 1 & c & 0 & 0 & 1 & 1 & 0 & 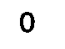 & 1 & & & & & & & 1 & 0 & 0 \\
\hline & 1 & 0 & $c$ & 0 & 1 & $c$ & 0 & 1 & 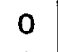 & 1 & 0 & 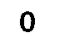 & & 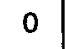 & & & & & & 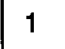 & 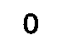 & 0 \\
\hline & 0 & 1 & $c$ & 0 & 0 & 1 & 0 & 1 & 0 & 0 & 1 & 0 & 0 & & & & & & & 0 & 0 & 1 \\
\hline & 1 & 0 & $c$ & 0 & 1 & 0 & 0 & 1 & 0 & 1 & 0 & 0 & 1 & 0 & & & & & & 0 & & 0 \\
\hline & 1 & 0 & $c$ & 0 & 0 & 1 & 0 & 1 & 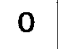 & 1 & 0 & 0 & & & & & & & & 0 & 0 & 1 \\
\hline & 0 & 1 & $c$ & c & 0 & 1 & 0 & 1 & 0 & 1 & 0 & 0 & 0 & & & & & & & 0 & 1 & 0 \\
\hline Coiguat & 0 & 1 & 0 & 0 & 1 & 0 & 0 & 1 & 0 & 0 & 1 & 0 & 0 & 1 & & & $c$ & & & 0 & 0 & 1 \\
\hline Come & 1 & 0 & 0 & 0 & 1 & $c$ & 0 & 0 & 1 & 1 & 0 & 0 & 0 & & & & & & & 0 & 1 & 0 \\
\hline Cooami & 0 & 0 & 1 & 0 & 1 & 0 & 0 & 0 & 1 & 0 & 1 & 0 & 1 & 0 & c & 0 & 1 & 1 & 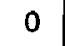 & 0 & 1 & 0 \\
\hline Coogoitá & 1 & 0 & 0 & 1 & 0 & 0 & 0 & 0 & 1 & 1 & 0 & 1 & 0 & 0 & 0 & 0 & 1 & 1 & c & 1 & 0 & 0 \\
\hline Coopacam & 1 & 0 & 0 & 0 & 1 & 0 & 0 & 1 & 0 & 1 & 0 & 0 & 0 & 1 & 0 & 0 & 1 & 1 & c & 0 & 1 & 0 \\
\hline Coopag & 0 & 1 & 0 & 0 & 1 & 0 & 0 & 1 & 0 & 0 & 1 & 0 & 0 & 1 & 0 & 1 & 0 & 1 & 0 & 0 & 0 & 1 \\
\hline Coopagro & 0 & 0 & 1 & 0 & 0 & 0 & 1 & 1 & 0 & 0 & 1 & 0 & 0 & 1 & 1 & 0 & 0 & 0 & 1 & 0 & 0 & 1 \\
\hline Coopaagrol & 1 & 0 & 0 & 0 & 1 & 0 & 0 & 0 & 1 & 1 & 0 & 0 & 0 & 1 & 0 & 1 & 0 & 1 & 0 & 0 & 1 & 0 \\
\hline Coopalto & 0 & 1 & 0 & 0 & 0 & 1 & 0 & 1 & 0 & 1 & 0 & 0 & 1 & 0 & 0 & 1 & 0 & 1 & 0 & 0 & 0 & 1 \\
\hline Coopamn & 0 & 0 & 1 & 0 & 1 & 0 & 0 & 1 & c & 0 & 1 & 0 & 0 & 1 & 0 & 1 & 0 & 0 & 1 & 0 & 1 & 0 \\
\hline Coopaqui & 0 & 1 & 0 & 0 & 1 & 0 & 0 & 1 & c & 0 & 1 & 0 & 1 & 0 & 0 & 0 & 1 & 1 & 0 & 0 & 1 & 0 \\
\hline Coopar & 1 & 0 & 0 & 0 & 0 & 1 & 0 & 1 & 0 & 0 & 1 & 0 & 1 & 0 & 0 & 1 & 0 & 0 & 1 & 0 & 0 & 1 \\
\hline Cooperbs & 1 & 0 & $c$ & 0 & 1 & 0 & 0 & 1 & 0 & 1 & 0 & 1 & 0 & 0 & 0 & 0 & 1 & 1 & 0 & 0 & 1 & 0 \\
\hline Cooperhe & 1 & 0 & 0 & 1 & 0 & 0 & 0 & 0 & 1 & 1 & 0 & 1 & 0 & 0 & 0 & 0 & 1 & 1 & 0 & 0 & 1 & 0 \\
\hline pern & 0 & 1 & 0 & 0 & 0 & 1 & 0 & 1 & 0 & 0 & 1 & 0 & 0 & 1 & 0 & 1 & 0 & 0 & 1 & 0 & 0 & 1 \\
\hline Coopersa & 1 & 0 & 0 & 1 & 0 & 0 & 0 & 0 & 1 & 1 & 0 & 1 & 0 & 0 & 0 & 1 & 0 & 1 & 0 & 0 & 1 & 0 \\
\hline & 0 & 1 & 0 & 0 & 1 & 0 & 0 & 0 & 1 & 1 & 0 & 0 & 0 & 1 & 0 & 0 & 1 & 0 & 1 & 0 & 1 & 0 \\
\hline Co & 0 & 0 & 1 & 0 & 0 & 1 & 0 & 1 & 0 & 0 & 1 & 0 & 0 & 1 & 1 & 0 & 0 & 0 & 1 & 0 & 0 & 1 \\
\hline & 0 & 1 & 0 & 0 & 1 & 0 & 0 & 0 & 1 & 1 & 0 & 0 & 1 & 0 & 0 & 1 & 0 & 1 & 0 & 0 & 1 & 0 \\
\hline rucoop & 0 & 0 & 1 & 1 & 0 & 0 & 0 & 0 & & 0 & 1 & 0 & 0 & 1 & 0 & 7 & 0 & 0 & 1 & 0 & 0 & \\
\hline
\end{tabular}

Fonte: dados da pesquisa. 


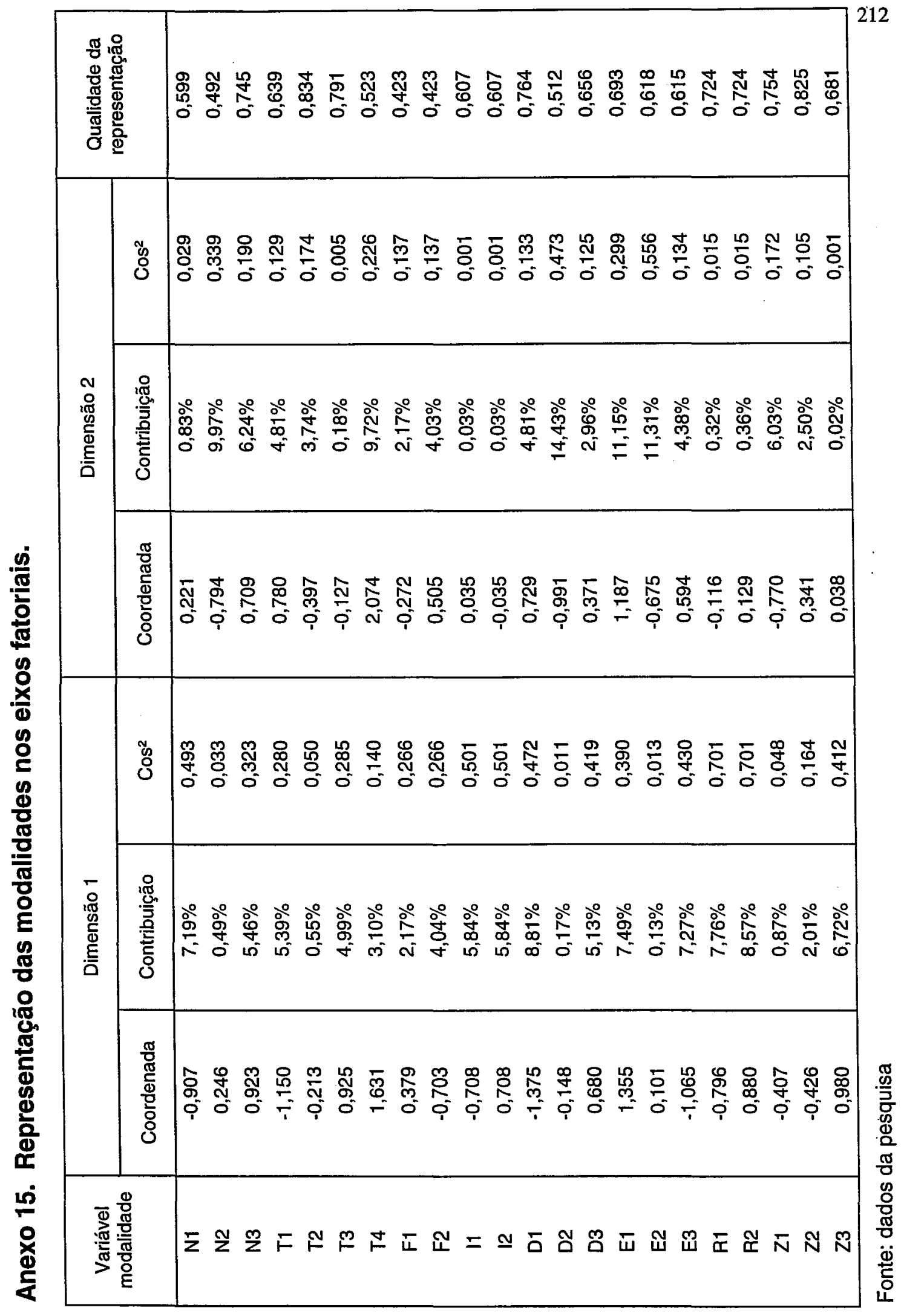


Anexo 16. Classificação e distância euclidiana das cooperativas da amostra ao centro de gravidade da classe.

\begin{tabular}{|c|c|c|c|}
\hline Grupo & REF. & Cooperativa & Distância \\
\hline A & $\begin{array}{l}\text { E } \\
d \\
O \\
n \\
h \\
g \\
i \\
r \\
D \\
a \\
V \\
C \\
b \\
f \\
B \\
W \\
Q \\
I \\
c \\
M\end{array}$ & $\begin{array}{l}\text { COMASIL } \\
\text { COOPERBAL } \\
\text { COCEDRO } \\
\text { COOPAGROL } \\
\text { CAPLO } \\
\text { BETÂNIA } \\
\text { COOPACAM } \\
\text { COOPERHORT } \\
\text { COOSERRANA } \\
\text { COOPERSANTA } \\
\text { CAIPIG } \\
\text { COAMIGA } \\
\text { GOITÁ } \\
\text { COAGRIL } \\
\text { CAMICIL } \\
\text { COOPAQUI } \\
\text { COOAMI } \\
\text { CAMPIC } \\
\text { CAMIC } \\
\text { COOPI }\end{array}$ & $\begin{array}{l}0,326 \\
0,326 \\
0,340 \\
0,340 \\
0,353 \\
0,353 \\
0,353 \\
0,353 \\
0,359 \\
0,366 \\
0,378 \\
0,390 \\
0,401 \\
0,407 \\
0,429 \\
0,439 \\
0,444 \\
0,455 \\
0,469 \\
0,469\end{array}$ \\
\hline B & $\begin{array}{l}\mathrm{R} \\
\mathrm{T} \\
\mathrm{N} \\
\mathrm{S} \\
1 \\
\mathrm{k} \\
\mathrm{P} \\
\mathrm{F} \\
\mathrm{V} \\
\mathrm{Z}\end{array}$ & $\begin{array}{l}\text { COAPIL } \\
\text { COOPERMIL } \\
\text { COIGUATU } \\
\text { CERVAP } \\
\text { COOPAR } \\
\text { COOPAG } \\
\text { COICÓ } \\
\text { COERBA } \\
\text { COOPALTO } \\
\text { CAMAGIL }\end{array}$ & $\begin{array}{l}0,204 \\
0,204 \\
0,279 \\
0,338 \\
0,338 \\
0,364 \\
0,376 \\
0,388 \\
0,388 \\
0,400 \\
\end{array}$ \\
\hline C & $\begin{array}{l}K \\
G \\
j \\
m \\
H \\
L \\
A \\
Y \\
r \\
e\end{array}$ & $\begin{array}{l}\text { CAPIVAB } \\
\text { CIVAB } \\
\text { COOPMOVA } \\
\text { COOPAGRO } \\
\text { COOPAMN } \\
\text { CAPI } \\
\text { BATAVO } \\
\text { CAMPAL } \\
\text { FRUCOOP } \\
\text { CAMPIB }\end{array}$ & $\begin{array}{l}0,261 \\
0,278 \\
0,278 \\
0,294 \\
0,294 \\
0,323 \\
0,375 \\
0,387 \\
0,410 \\
0,421\end{array}$ \\
\hline
\end{tabular}

Fonte: dados da pesquisa. 


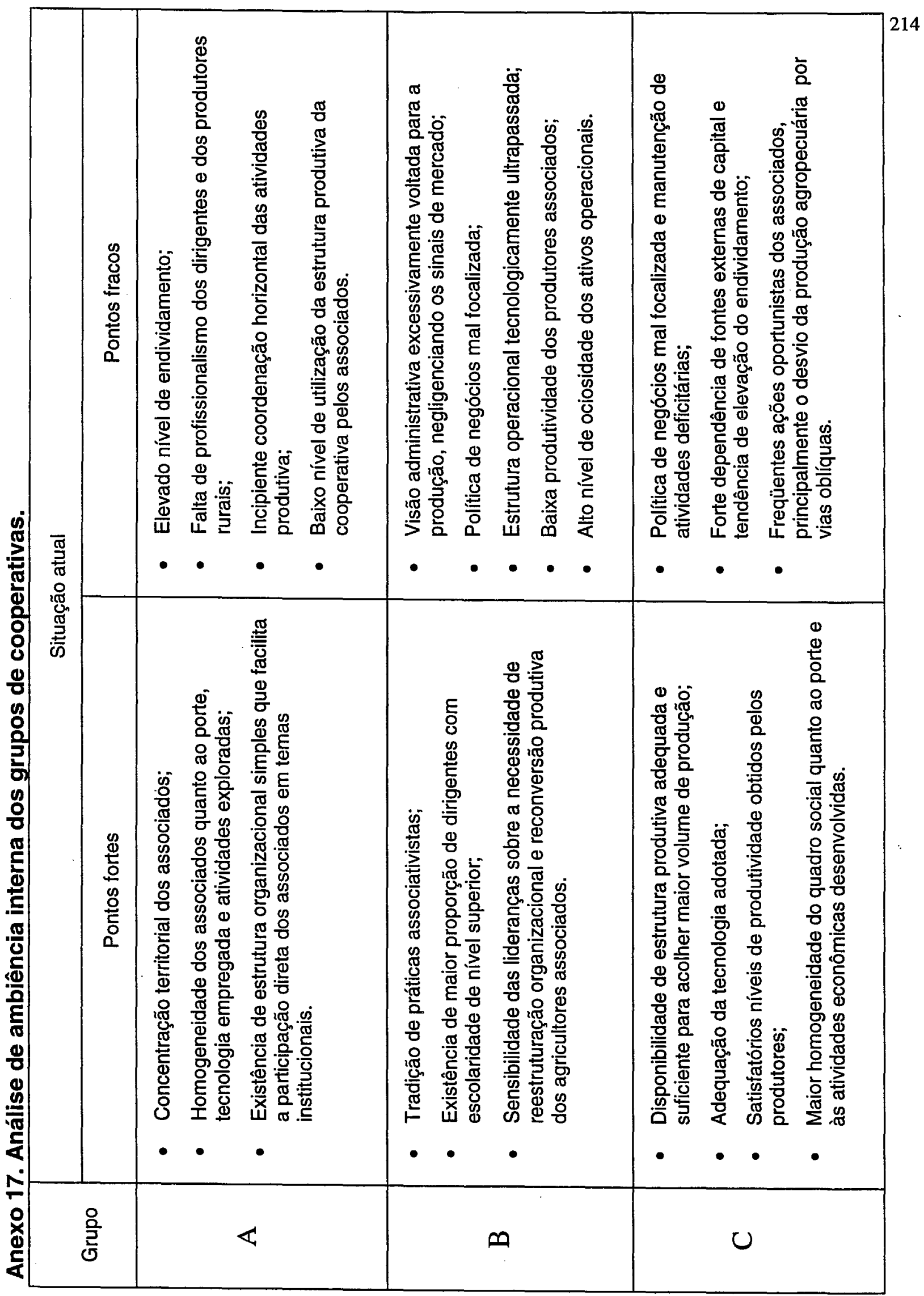




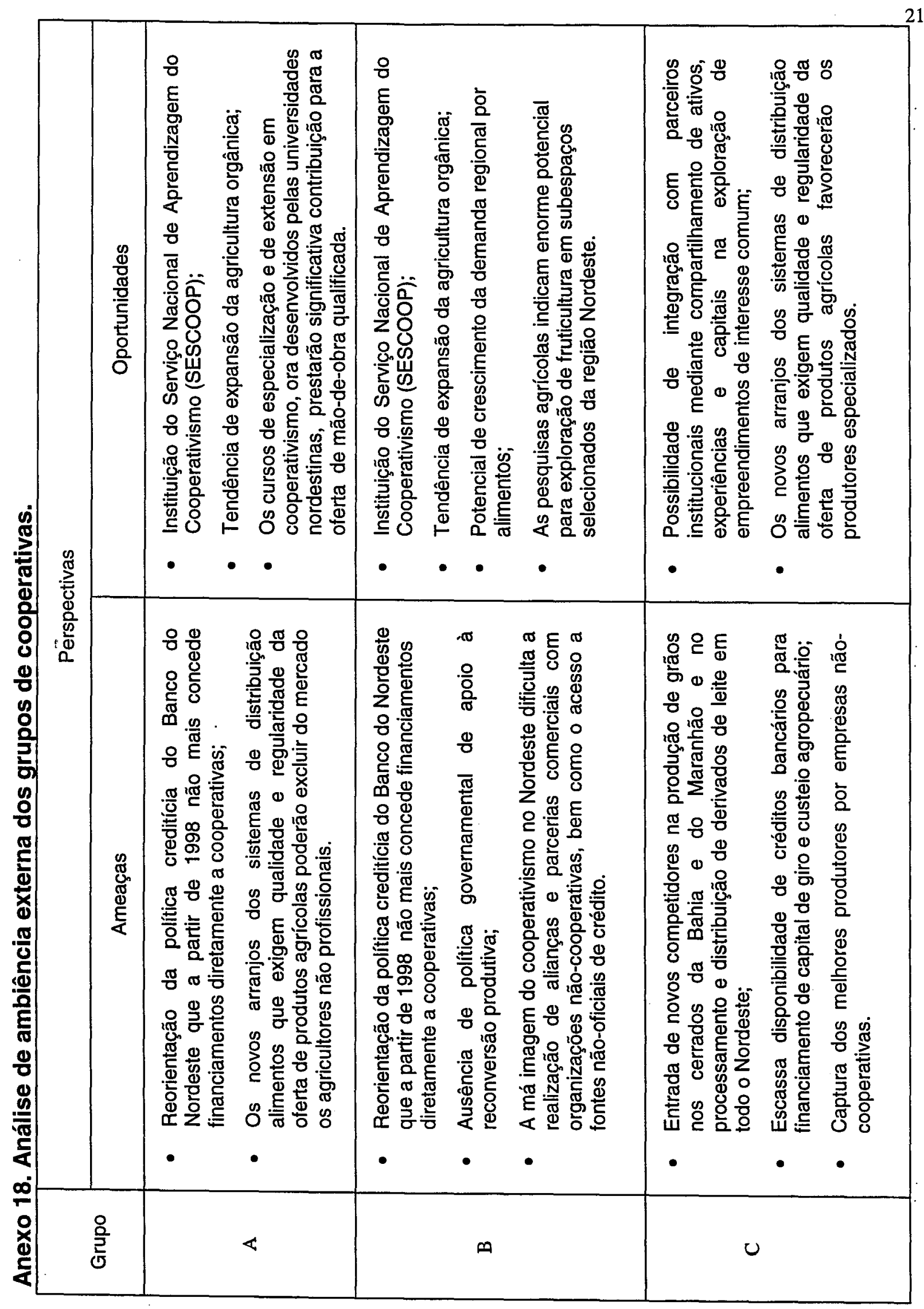


Anexo 19. Caracterização dos grupos de cooperativas.

\begin{tabular}{|c|c|c|c|c|}
\hline Aspecto considerado & Grupo A & Grupo B & Grupo C & Setor ${ }^{1}$ \\
\hline Número médio de associados & 328 & 1.003 & 877 & 1.340 \\
\hline Número médio de empregados & 10 & 34 & 53 & 123 \\
\hline Número médio de dirigentes & 5,9 & 4,8 & 6,2 & 12,3 \\
\hline $\begin{array}{l}\text { Proporção de dirigentes com } \\
\text { escolaridade superior (\%) }\end{array}$ & 5,1 & 35,4 & 12,9 & 41,0 \\
\hline $\begin{array}{l}\text { Proporção de dirigentes com } \\
\text { escolaridade média (\%) }\end{array}$ & 23,9 & 31,3 & 32,3 & 27,0 \\
\hline Ativo total médio $(\mathrm{R} \$ 1.000)$ & 2.545 & 5.027 & 6.450 & ND \\
\hline Proporção de operações de repasse (\%) & 68,8 & 50,7 & 8,4 & ND \\
\hline Faturamento líquido médio $(R \$ 1.000)$ & 178 & 1.136 & 5.473 & 25.426 \\
\hline Faturamento por associado $(\mathrm{R} \$ 1.000)$ & 0,5 & 1,1 & 6,2 & 19,0 \\
\hline Faturamento por empregado ( $R \$ 1.000)$ & 17,8 & 33,4 & 103,3 & 206,7 \\
\hline Sobras líquidas médias (R\$1.000) & -47 & -51 & -17 & -776 \\
\hline Liquidez corrente & 1,09 & 1,43 & 1,43 & ND \\
\hline Liquidez geral & 1,01 & 1,06 & 1,12 & ND \\
\hline Endividamento total (\%) & 89,3 & 76,9 & 59,3 & $69,9^{2}$ \\
\hline Grau de Imobilização geral (\%) & 9,6 & 17,6 & 31,1 & $53,5^{2}$ \\
\hline Giro do ativo total (\%) & 6,9 & 22,6 & 84,9 & ND \\
\hline Margem líquida (\%) & $-13,2$ & $-4,5$ & $-0,6$ & $-3,1$ \\
\hline Retorno sobre ativo total (\%) & $-0,92$ & $-1,03$ & $-0,54$ & $-8,6^{2}$ \\
\hline Retorno sobre patrimônio líquido (\%) & $-8,61$ & $-4,45$ & $-1,33$ & $-10,9$ \\
\hline
\end{tabular}

\footnotetext{
${ }^{1}$ Lopes et al. (1997).

${ }^{2}$ Balanço Anual. São Paulo: Gazeta Mercantil, 1998.
} 


\section{REFERÊNCIAS BIBLIOGRÁFICAS}

ALVES, M.R.P.A.A. Logística agroindustrial. In: BATALHA, M. (Coord.) Gestão agroindustrial. São Paulo: Atlas, 1997. cap.4. p.139-214.

ANDRADE, M.P. Restrutura fundiária, modernização e distribuição da renda na agricultura matogrossense. Piracicaba, 1989. 201p. Dissertação (Mestrado) - Escola Superior de Agricultura Luiz de Queiroz, Universidade de São Paulo.

ANUÁRIO DO COOPERATIVISMO BRASILEIRO - 1998. Brasília: OCB, 1998. 175p.

ARAÚJO, U.M. Assimetria de informação no crédito rural: aspectos teóricos e um modelo para classificação de risco dos créditos concedidos a cooperativas agropecuárias. Piracicaba, 1996. 81p. Tese (Doutorado) Escola Superior de Agricultura Luiz de Queiroz, Universidade de São Paulo.

ASSAF NETO, A. Estrutura e análise de balanço: um enfoque econômicofinanceiro. São Paulo: Atlas, 2000. 298p.

BALANÇO ANUAL. São Paulo: Gazeta Mercantil, 1998. 420p.

BANCO DO NORDESTE DO BRASIL. Projeto Cooperação e Associativismo. Fortaleza: BNB, 1999. 32p.

BECHO, R.L. Tributação das cooperativas. São Paulo: Dialética, 1997. 191p. 
BENECKE, D.W. Cooperação e desenvolvimento: o papel das cooperativas no processo de desenvolvimento econômico nos países do terceiro mundo. Porto Alegre: Coojornal; Recife: Assocene, 1980. 240p.

BERGAMASCO, S.M.P.P. Caracterização da agricultura familiar no Brasil, a partir dos dados da PNAD. Reforma Agrária, v.25, n.2/3, p.167-177, maio/dez.1995.

BENETTI, M.D. Origem e formação do cooperativismo empresarial no Rio Grande do Sul: uma análise do desenvolvimento da Cotrijuí, Cotrirosa e Fecotrigo - 1957/1980. Porto Alegre: Fundação de Economia e Estatística, 1985, 171p.

BIALOSKORSKI NETO, S. Agribusiness cooperativo: economia, doutrina e estratégia de gestão. Piracicaba, 1994. 135p. Dissertação (Mestrado) Escola Superior de Agricultura Luiz de Queiroz, Universidade de São Paulo.

BIALOSKORSKI NETO, S. Cooperativas: economia, crescimento e estrutura de capital. Piracicaba, 1998a. 257p. Tese (Doutorado) - Escola Superior de Agricultura Luiz de Queiroz, Universidade de São Paulo.

BIALOSKORSKI NETO, S. Cooperativismo: direitos de propriedade e eficiência econômica, a nova geração de cooperativas no Canadá. In:CONGRESSO BRASILEIRO DE ECONOMIA E SOCIOLOGIA RURAL, Poços de Caldas, 1998b. Anais. Brasília: SOBER, 1998b. p. 745-754.

BOETTCHER, E. La funcionalidad de la cooperación económica. Trad. de V. Domínguez e R. Gumprecht. Santiago: CECUC/ICECOOP, 1976. 171p.

BOYD, H.W.; BOYD JR., H.W.; WESTFALL, R. Pesquisa mercadológica: texto e casos. Trad. de Afonso C. A. Arantes e Maria Isabel R. Hopp. Rio de Janeiro: Fundação Getúlio Vargas, 1987. 803p. 
BRASIL. Lei $n^{\circ} 5.764$ de 16 de dezembro de 1971. Define a política de cooperativismo, institui o regime jurídico das sociedades cooperativas e dá outras providências.

BULGARELLI, W. Concentração de empresas e direito antitruste. São Paulo: Atlas, 1996. 335p.

BULGARELLI, W. As sociedades cooperativas e a sua disciplina jurídica. Rio de Janeiro: Renovar, 1998. 388p.

BUSSAB, W.O.; MIAZAKI, E.S.; ANDRADE, D.F. Introdução à análise de agrupamentos. São Paulo: Associação Brasileira de Estatística (ABE), 1990. 576p. /Apresentado no 9. Simpósio Nacional de Probabilidade e Estatística/

CERTO, S.C.; PETER, J.P. Administração estratégica: planejamento e implantação da estratégia. Trad. de F.D. Steffen. São Paulo: Makron Books, 1993. 469p.

CHIAVENATO, I. Administração nos novos tempos. Rio de Janeiro: Campus, 1999a. 710p.

CHIAVENATO, I. Teoria Geral da Administração. São Paulo: Campus, 1999b. v.2. $831 \mathrm{p}$.

COOK, M. Evolução das cooperativas de nova geração nos Estados Unidos na década de 90. In: CONGRESSO DE COOPERATIVISMO, 11., Brasília, 1997. Anais. Brasília: OCB, 1997. 7p.

COOPERATIVA AGRÍCOLA MISTA DE ANGICAL DO PIAUÍ. Plano interno de desenvolvimento. Angical do Piauí: CAMAPLA, 1999. 640p. 
CORRÊA, A. M. C. J. Distribuição de renda e pobreza na agricultura brasileira: 1981-1990. Piracicaba: UNIMEP, 1998. 260p.

CRIVISQUI, E. Analisis Factorial de Correspondências: un instrumento de investigación en Ciências Sociales. Bruxelas: LMTD Université Libre de Bruxelles; Asunción: Universidad Católica de Asunción, 1993. 302p.

CRIVISQUI, E. Presentación del análisis de componentes principales. Campinas: UNICAMP.IE, 1998. /Apresentado ao Seminário de Métodos Estatísticos Aplicados às Ciências Humanas, Programme PRESTA/

CRIVISQUI, E. Apresentação dos métodos de classificação. Campinas: UNICAMP.IE, 1998. /Apresentado ao Seminário de Métodos Estatísticos Aplicados às Ciências Humanas, Programme PRESTA/

CÔTÉ, D.; CARRÉ, G.; BEAULIEU, M. et al. 1995 Profile: agricultural cooperation throughout the world. Québec: Centre de Gestion des Coopératives, École des Hautes Études Commerciales, 1995. 103 p.

DANIEL, A.; GAL, N. (Coord.) Pesquisa sobre organização cooperativa no Nordeste do Brasil. Fortaleza: BNB, 1981. 426p.

DUARTE, L. M. G. O cooperativismo como espaço de politização da questão tecnológica. In: PORTO, M.S.G. (Org.) Politizando a tecnologia no campo brasileiro. Rio de Janeiro: Relume-Dumará, 1997. cap. 11, p. 107125.

ESCHENBURG, E. Idéia para o aprimoramento da auditoria em cooperativias no Brasil: uma tentativa para estimular a discussão científica. Trad. de M. C. Dresler e A. O. Dresler. São Leopoldo: Unisinos, 1986. 149p. 
ESCHENBURG, R. Aportes de la teoria economica a la discusion sobre el papel de las cooperativas. Bogotá: CIUDEC, 1988. 62p.

ESCOFIER, B; PAGÈS, J. Análisis factoriales simples y múltiples: objetivos, método e interpretación. Bilbao: Universidad del Pais Vasco, 1992. 285p.

FERREIRA, M.L. Estado e cooperativismo agrícola no Brasil: Contribuição ao estudo da atuação governamental no desenvolvimento de uma modalidade associativa. São Paulo, 1988. 197p. Dissertação (Mestrado) - Faculdade de Economia, Administração e Contabilidade, Universidade de São Paulo.

FRANKE, W. 0 direito das sociedades cooperativas. São Paulo: Saraiva, 1973. 157p.

FREITAS, F.C.G.; SOUZA, R.C.; CASTELO, A.M. A mensuração do modelo de estrutura-conduta-desempenho: 0 caso da construção civil paulista. São Paulo: Fundação Getúlio Vargas, set.1998. (Textos para Discussão. Série Economia de Empresas, n.68).

GAL, N. A organização cooperativa e o desenvolvimento rural. Fortaleza: BNB, 1981. 104p.

GITMAN, L.J. Princípios de administração financeira. Trad. de A. Ridolfo Neto, J.A.A. Salazar e L.A. Bertucci. São Paulo: Harbra, 1997. 841p.

GRECO, A.A.L.; AREND, L.R. Contabilidade: teoria e prática básicas. Porto Alegre: Sagra Luzzatto, 1998. 584p.

HELMBERGER, P.; HOOS, S. Cooperative enterprise and organization theory. Journal of farm economics, v.44, n.2, p.275-290, 1962.

HOFFMANN, R. Distribuição da renda e pobreza na agricultura brasileira. Políticas Públicas, Brasília, n.127, p.3-111, 1990. 
HOFFMANN, R. A dinâmica da modernização da agricultura e a distribuição de renda em 157 microregiões homogêneas do Brasil. Revista de Economia e Sociologia Rural, Brasília, v.30, n. 4, p.271-290, out./dez. 1992.

HOFFMANN, R. Componentes principais e análise fatorial. 3.ed. Piracicaba: ESALQ-USP, 1994. 37p. (Série Didática, n.90).

HOFFMANN, R.; KAGEYAMA, A.A. Modernização da agricultura e distribuição de renda no Brasil. Pesquisa e Planejamento Econômico, Rio de Janeiro, v.15, n.1, p.171-208, abr.1985.

INSTITUTO BRASILEIRO DE GEOGRAFIA E ESTATÍSTICA. Tabulação especial do Censo Agropecuário 1995-1996. Rio de Janeiro: Centro de Documentação e Disseminação de Informações - CDDI, 1998. 366p.

IRION, J.E.O. Cooperativismo e economia social. São Paulo: Editora STS, 1997. 344p.

IUDÍCIBUS, S. Contabilidade gerencial. São Paulo: Atlas, 1980. $301 p$.

JOHNSTON, B.F.; MELLOR, J.W. El papel de la agricultura en el desarrollo económico. El Trimestre Económico, v.1, n.1, jan./mar.1961.

KAGEYAMA, A.A.; LEONE, E. T. Uma tipologia dos municípios paulistas com base em indicadores sociodemográficos. Campinas: Unicamp, 1999. 52p. (Texto para Discussão. IE/Unicamp, n.66).

KAGEYAMA, AA.; SILVEIRA, J.M. Agricultura e questão regional. Revista de Economia e Sociologia Rural, v.35, n.2, p.9-33, 1997.

KOTLER, P. Administração de marketing. Trad. de Ailton B. Brandão. São Paulo: Atlas, 1994. 676p. 
LAMARCHE, H. (Coord.) A agricultura familiar: comparação internacional. Trad. de A.M.N. Tijiwa. Campinas: Unicamp, 1993. 336p.

LAZZARINI, S.G.; BIALOSKORSKI NETO, S.; CHADDAD, F.R. Decisões financeiras em cooperativas: fontes de ineficiência e possíveis soluções. Gestão \& Produção, v.6, n.3, p.257-268, dez.1999.

LEBART, L. et al. Statistique exploratoire multidimensionnelle. Paris: Dunod, 1995.

LEONE, E.T. Modernização e distribuição de renda na agricultura no estado da Bahia em 1980. Piracicaba, 1988. 152 p. Dissertação (Mestrado) - Escola Superior de Agricultura Luiz de Queiroz, Universidade de São Paulo.

LIMA, R. F. Direito cooperativo tributário. São Paulo: Limonad, 1997. 284p.

LOPES, I.V.; LOPES, M.R. (Coord.) I Censo do cooperativismo brasileiro: perfil do dirigente cooperativista. Rio de janeiro: Fundação Getúlio Vargas, 1997. 29p. (Relatório de pesquisa).

LOPES, I.V.; LOPES, M.R.; ALIMANDRO, R.N.C. (Coord.) I Censo do cooperativismo brasileiro: participação no mercado das cooperativas agropecuárias. Rio de janeiro: Fundação Getúlio Vargas, 1997. 76p. (Relatório de pesquisa).

MARION, J.C. Contabilidade empresarial. São Paulo: Atlas, 1998. 514p.

MARQUES, B.F. Direito agrário brasileiro. Goiânia: AB, 1998. 273p.

MARTINS, F. Curso de direito comercial: empresa comercial, empresários individuais, microempresas, sociedades comerciais, fundos de comércio. Rio de Janeiro: Forense, 1999. 384p.

MATTAR, F.N. Pesquisa de marketing. São Paulo: Atlas, 1993. 350p. 
MAUGET, R.; DECLERCK, F. Structures, strategies, and performance of E.C.Agricultural cooperatives. Agribusiness, v.12, n.3, p.265-275, 1996.

MEDEIROS, N.H. A competição schumpeteriana e a organização cooperativa: o caso da Cocamar. São Paulo, 1995. 235p. Tese (Doutorado) - Faculdade de Economia, Administração e Contabilidade, Universidade de São Paulo.

MORAES, A. Direito constitucional. São Paulo: Atlas, 2000. 797p.

MOURA, V. Caráter e tendências do movimento cooperativo no Brasil: a problemática cooperativista no desenvolvimento econômico. São Paulo: Fundação Friedrch-Naumann, 1973. 32p.

NEVES, S.; VICECONTI, P.E.V. Contabilidade avançada e análise das demonstrações financeiras. São Paulo: Frase Editora, 1999. 580p.

NILSSON, J. Una nueva generación de cooperativas agrícolas. Revista de La Cooperación Internacional, Instituto de Cooperativismo e Associativismo, v.30, n.1, 1997.

ORGANIZAÇÃO DAS COOPERATIVAS BRASILEIRAS. Números do cooperativismo brasileiro - 1997. Brasília: Departamento Técnico e Econômico, 1997. 20p.

OLIVEIRA JÚNIOR, C.C. Avaliação da eficiência empresarial das cooperativas. Curitiba: OCEPAR, 1996. 80p.

PANZUTTI, R. Estratégias de financiamento das cooperativas agrícolas no estado de São Paulo: caso da Cooperativa dos Agricultores da Região de Orlândia. São Paulo: Instituto de Cooperativismo e Associativismo, 1997. $236 p$.

PINHO, D. B. Economia e cooperativismo. São Paulo: Saraiva, 1977. 177p. 
PINHO, D.B. O pensamento cooperativo e o cooperativismo brasileiro. São Paulo: CNPq, 1982. 272 p.

POLONIO, W. A. Manual das sociedades cooperativas. São Paulo: Atlas, 1998. 185p.

REGO, J.J.M. Cooperativismo no tempo: 1966-1972. Recife: Sudene, 1973. 98p.

REGO, J.J.M. Avaliação do cooperativismo nordestino. In: PINHO, D.B. (Org.) As grandes coordenadas da memória do cooperativismo brasileiro: avaliação do cooperativismo e modernização da agricultura cooperativista. Brasília: OCB/Coopercultura, 1991. 696p.

REQUEJO, L.M.H. A estrutura de capital das cooperativas agrícolas no Brasil: fatores que levam a sub-utilização de crédito, excesso em investimentos e a falta de motivação dos associados. In: CONGRESSO DE COOPERATIVISMO, 11., Brasília, 1997. Anais. Brasília: OCB, 1997. 18p.

SALOMON, D.V. Como fazer uma monografia. São Paulo: Martins Fontes, 1999. 412p.

SCHMIESING, B. Theory of marketing cooperatives and decision making. In: COBIA, D. (Ed.) Cooperatives in agriculture. New Jersey: Pretice Hall, 1989. cap.10, p.156-173.

SCHNEIDER, J. O. Democracia, participação e autonomia cooperativa. São Leopoldo: Unisinos, 1991. 416p.

SEMENIK, R.J.; BAMOSSY, G. J. Princípios de Marketing. Trad. de L. Peres. São Paulo: Makron Books, 1995. 867p. 
SEXTON, R.J. Cooperatives and the forces shaping agricultural marketing. American Journal of Agricultural Economics, v.68, p.1167-72, 1986.

SHARMA, S. Applied Multivariete Techiques. New York: John Wiley \& Sons, 1996. 493p.

SOUZA, N.J. Desenvolvimento econômico. São Paulo: Atlas, 1999. 415p.

STEVENSON, W.J. Estatística aplicada à administração. Trad. de Alfredo Alves de Farias. São Paulo: Harbra, 1981. 495p.

VEIGA, J.E. Delimitando a agricultura familiar. Reforma Agrária, v.25, n.2/3, p.128-141, maio/dez. 1995. 


\section{APÊNDICES}


Apêndice 1. Relação das cooperativas integrantes do universo considerado na pesquisa.

\begin{tabular}{|c|c|c|c|c|}
\hline Num. Geral & Ord. Estado & Estado & RAZÄO SOCIAL & Escore \\
\hline 1 & 1 & AL & COOP.AGROP.DE PEQUENOS PRODUTORES DE INHAPI & $-0,584$ \\
\hline 2 & 2 & $\overline{\mathrm{AL}}$ & COOP. MISTA AGROPECUARIA E DE PROD. S.J.LAGE & $-0,456$ \\
\hline 3 & 3 & $\mathrm{AL}$ & COOP MISTA DOS PLANTADORES DE CANA DE AL & 0,039 \\
\hline 4 & 4 & $\mathrm{AL}$ & COOPERATIVA AGROPECUARIA DE P DOS INDIOS & 0,092 \\
\hline 5 & 5 & AL & COOPERATIVA REG.DOS PROD.DE ACUCAR DE AL & 0,423 \\
\hline 6 & 6 & $\mathrm{AL}$ & COOPERATIVA DE CREDITO RURAL DE SAO JOSE & $1, \overline{148}$ \\
\hline 7 & 7 & AL & COOPERATIVA AGROPECUARIA DE MAJOR IZIDORO & 3,376 \\
\hline 8 & 8 & AL & COOP. AGROP. REGIONAL DE SANTANA DO IPANEMA & 3,846 \\
\hline 9 & 9 & AL & COOP. DE COL. AGROP. IND. PINDORAMA & 7,551 \\
\hline 10 & 1 & BA & COOP DOS FAZEND DE CACAU BAHIA-COFABA & $-0,642$ \\
\hline 11 & 2 & $B A$ & COOPERATIVA AGRICOLA ILHEUS LTDA & $-0,642$ \\
\hline 12 & 3 & $B A$ & COCIP COOP CACAUICULTORES DE IPIAU LTDA & $-0,642$ \\
\hline 13 & 4 & BA & COOP AGRIC CAMACAN LTDA & $-0,642$ \\
\hline 14 & 5 & BA & COOP AGRIC M P ASSOC A SAO JOAQUIM & $-0,642$ \\
\hline 15 & 6 & $\mathrm{BA}$ & COOPERRETIRO-COOP.MISTA AGROP.DOS AGRIC. & $-0,641$ \\
\hline 16 & 7 & $\mathrm{BA}$ & COOMAB-COOP.MISTA - FINACOM & $-0,635$ \\
\hline 17 & 8 & $\mathrm{BA}$ & COOPERATIVA AGROPECUARIA DE PEDRAO LTDA. & $-0,635$ \\
\hline 18 & 9 & BA & COOP MISTA DOS PESCAD DE VALENCA RESP & $-0,625$ \\
\hline 19 & 10 & $\mathrm{BA}$ & COOPERATIVA DE PROD AGROP ASSENT.UNIAO & $-0,624$ \\
\hline 20 & 11 & BA & COOPERATIVA DOS IRRIGANTES DE JACURICY L & $-0,622$ \\
\hline 21 & 12 & BA & COOP. MISTA DE PROD. AGROP. DOS ASSENT. LTDA & $\cdot 0,612$ \\
\hline 22 & 13 & $\mathrm{BA}$ & COOP. MISTA DOS AGRIC. DO SERTÄO DE S. FRANCISCO & $\cdot 0,610$ \\
\hline 23 & 14 & BA & COOPERATIVA DE PROD AGROP DO ASS ETELVIN. LTDA & $-0,608$ \\
\hline 24 & 15 & BA & COOPERATIVA APICOLA DE JACOBINA LTDA & $-0,604$ \\
\hline 25 & 16 & $\mathrm{BA}$ & COOP AGROPEC MISTA REG. DA REIGĀO DE ALAGOINHAS & $-0,600$ \\
\hline 26 & 17 & BA & COOPERATIVA UNIAO DE CONS FEIRENSE LTDA & $-0,590$ \\
\hline 27 & 18 & $\mathrm{BA}$ & COOPERATIVA AGROPECUARIA DE CAPELA DO AL LTDA. & $-0,586$ \\
\hline 28 & 19 & $\mathrm{BA}$ & COOPERATIVA MISTA DOS PESCADORES DO MUNI. LTDA & $-0,577$ \\
\hline 29 & 20 & BA & COOPERFEIRA COOP PEC F SANTANA & $-0,562$ \\
\hline 30 & 21 & BA & COOPERATIVA DE PROD.AGROP.FAZ.AMARALINA & $-0,558$ \\
\hline 31 & 22 & BA & COOPERATIVA DE PROD AGROP DO CORTE GRAND & $-0,525$ \\
\hline 32 & 23 & $\mathrm{BA}$ & COOPERATIVA DE PRO DO ASS LAG E CALD LTDA & $-0,523$ \\
\hline 33 & 24 & $\mathrm{BA}$ & COOPERATIVA DE PROD.ASSENT.MOCAMBO LTDA. & $-0,516$ \\
\hline 34 & 25 & $\mathrm{BA}$ & COOP. AGRICOLA MISTA DOS AGROPEC. DE PIN. LTDA & $-0,513$ \\
\hline 35 & 26 & BA & COOPERRECONCAVO COOP.AGRO-INDL.DO RECONC. BAIANO & $-0,512$ \\
\hline 36 & 27 & BA & COOPERATIVA AGROPECUARIA UNIDOS VENCEREMOS LTDA & $-0,504$ \\
\hline 37 & 28 & BA & COOPERATIVA DE PRODUCAO AGROPECUARIA NOV. LTDA & $-0,459$ \\
\hline 38 & 29 & BA & COOPERATIVA DOS IRRIGANTES DO VAZABARAIS LTDA & $-0,449$ \\
\hline 39 & 30 & $\mathrm{BA}$ & COOP AGR MISTA DE MANDACARU LTDA & $-0,380$ \\
\hline 40 & 31 & BA & COOPEC-COOPERATIVA MISTA DOS PESCS.CANAV. LTDA & $-0,373$ \\
\hline 41 & 32 & BA & COOP.REG.DE REF.AGRARIA DO SUDOESTE DA BAHIA LTDA & $-0,216$ \\
\hline 42 & 33 & BA & COOPERATIVA AGROPECUARIA DE GUANAMBI LTDA & $-0,097$ \\
\hline 43 & 34 & BA & COOP. REG. DE REFORMA AGRARIA DO EXT. SUL LTDA. & 0,029 \\
\hline 44 & 35 & BA & COOPERATIVA AGR.M.R.A.OPER.FINACON & 0.060 \\
\hline 45 & 36 & BA & COOPERE-COOPERATIVA VALENTENSE DE CREDIT. LTDA & 0,103 \\
\hline 46 & 37 & BA & COOPERATIVA DE PROD. AGROP. CONSTRUINDO LTDA. & 0,103 \\
\hline 47 & 38 & BA & COOP AGRIC MISTA DO PER IRRI DE CURAÇA LTDA. & 0.115 \\
\hline 48 & 39 & BA & COOPERATIVA MISTA AGROPECUARIA DE OUROLA LTDA & 0,269 \\
\hline 49 & 40 & $\mathrm{BA}$ & COOGRAP-COOP.GRAPIUNA DE AGROPECUARISTAS LTDA & 0,346 \\
\hline 50 & 41 & BA & COOPERATIVA AGROPECUARIA DE CANDIBA LTDA & 0,728 \\
\hline
\end{tabular}




\begin{tabular}{|c|c|c|c|c|}
\hline Num. Goral & Ord. Estado & Estado & RAZĀO SOCIAL & Escore \\
\hline 51 & 42 & BA & COOPERATIVA AGRICOLA MISTA DO PER.IRR.MA LTDA & 0,781 \\
\hline 52 & 43 & BA & COOPERATIVA REGIONAL DOS ASSENTADOS DO S. LTDA. & 1,092 \\
\hline 53 & 44 & BA & COOP. CENTRAL DE LAT. DA BAHIA RESP. LTDA & 1,175 \\
\hline 54 & 45 & BA & COOPERATIVA CENTRAL DO CACAU LTDA & 2,946 \\
\hline 55 & 46 & BA & COOPERATIVA AGRICOLA DE COTIA LTDA & 4,611 \\
\hline 56 & 1 & CE & COOP. DE PROD. DO ASSENT. S. JOAO DA COM. LTDA & $-0,629$ \\
\hline 57 & 2 & CE & COOPERATIVA DOS IRRIGANTES DE PENTECOSTE LTDA & $-0,624$ \\
\hline 58 & 3 & $\mathrm{CE}$ & COPERCENTRO COOP AGROIND DO SERTAO CENT. LTDA & $-0,619$ \\
\hline 59 & 4 & CE & COOPERATIVA AGROPECUARIA DE ITAPIPOCA LTDA & $-0,619$ \\
\hline 60 & 5 & $\mathrm{CE}$ & COOPERATIVA MISTA AGROP DE PEQ PRODUTORES LTDA & $.0,618$ \\
\hline 61 & 6 & $\mathrm{CE}$ & COOPERATIVA DOS IRRIG DA ZONA QUATRO LTDA & $-0,608$ \\
\hline 62 & 7 & CE & COOPECHAS-COOP DOS PRODUTORES DE CHAPEUS LTDA & $-0,594$ \\
\hline 63 & 8 & $\mathrm{CE}$ & COOPAMA COOP PRODUCAO AGROPECUARIA LTDA & $.0,578$ \\
\hline 64 & 9 & CE & COOIVA-COOP.INDUSTRIAL DO VALE DO JAGUARIBE LTDA & -0.546 \\
\hline 65 & 10 & $\mathrm{CE}$ & COOPACC-COOP.DOS PROD.DO ALUV.CHAP.E CAA. LTDA & $\cdot 0,546$ \\
\hline 66 & 11 & CE & COOP DOS AGROPECUARISTAS DO PROJ. IRRIGADO LTDA. & $.0,526$ \\
\hline 67 & 12 & $\mathrm{CE}$ & COOPERATIVA DE PESCA ARTESANAL DA BALEIA LTDA & $-0,493$ \\
\hline 68 & 13 & CE & COOPERATIVA AGRICOLA MISTA DE JABURUNA LTDA & $\cdot 0,469$ \\
\hline 69 & 14 & CE & COOP DOS PROD IRRIGANTES DE ICO LTDA. & -0.467 \\
\hline 70 & 15 & CE & COOP. MISTA DO VALE DO JAGUARIBE LTDA & $-0,460$ \\
\hline 71 & 16 & $\mathrm{CE}$ & COOPERATIVA DOS IRRIGANTES DE FORQUILHA LTDA & $-0,456$ \\
\hline 72 & 17 & $\mathrm{CE}$ & COAPICAR-COOP DOS APICULTORES DO CARIRI LTDA & $-0,453$ \\
\hline 73 & 18 & CE & COOPERATIVA AGROPECUAAIA DE QUIXERAMOBIM LTDA & $-0,436$ \\
\hline 74 & 19 & $\mathrm{CE}$ & COOPERATIVA DOS IRRIGANTES PIONEIROS LTDA & $-0,414$ \\
\hline 75 & 20 & $\mathrm{CE}$ & COOP. AGRIC. MISTA DE MORADA NOVA LTDA. & $-0,403$ \\
\hline 76 & 21 & $\mathrm{CE}$ & COOPERATIVA DOS IRRIGANTES DO VALE DO CURU LTDA & $-0,393$ \\
\hline 77 & 22 & $\mathrm{CE}$ & COOPAJA - COOP DOS PROD AGROPEC. DE JAGUARIUNA & $-0,374$ \\
\hline 78 & 23 & GE & COOP. DOS FAUTICULTORES DE MORADA NOVA LTDA & $-0,371$ \\
\hline 79 & 24 & CE & CDERQ-COOPERATIVA DE DESENVOLVIMENTO RUR. LTDA & $-0,334$ \\
\hline 80 & 25 & CE & COOPABS-COOP.AGROINDUSTRIAL DE BREJO SANTO LTDA & $-0,317$ \\
\hline 81 & 26 & GE & COOPERATIVA AGROINDUSTRIAL DE ARACATI LTDA & $-0,310$ \\
\hline 82 & 27 & CE & COOPERATIVA DOS AGROPECUARISTAS DE EXU LTDA & $-0,296$ \\
\hline 83 & 28 & $\mathrm{CE}$ & COOPERATIVA AGRICOLA DE PIQUET CARNEIRO LTDA & $-0,274$ \\
\hline 84 & 29 & $\mathrm{CE}$ & COOP.PROD.AGROP.AGUIA ASSENT.SANT.LTDA. & $-0,251$ \\
\hline 85 & 30 & CE & COOP.CENTRAL DOS PROD.DE ALGODAO E ALIM. LTDA. & $-0,235$ \\
\hline 86 & 31 & $\mathrm{CE}$ & COOPEMASA-COOP.DOS PEQ. E MEDIOS AGROP. LTDA & $-0,209$ \\
\hline 87 & 32 & $\overline{\mathrm{CE}}$ & COOPERATIVA DOS IRRIGANTES DE LIMA CAMPO LTDA & $-0,206$ \\
\hline 88 & 33 & $\overline{\mathrm{CE}}$ & COOPERATIVA AGROPECUARIA DO TRAIRI LTDA & $-0,203$ \\
\hline 89 & 34 & $\mathrm{CE}$ & COOPERATIVA DE CREDITO DE BARBALHA LTDA & $-0,150$ \\
\hline 90 & 35 & $\mathrm{CE}$ & COMAPIL-COOPER. MISTA AGROP.DE ALEGRETE LTDA. & $-0,147$ \\
\hline 91 & 36 & $\mathrm{CE}$ & COOPAB-COOPERATIVA AGROINDUSTRIAL DO BAR. LTDA & $-0,133$ \\
\hline 92 & 37 & $\mathrm{CE}$ & COOPERRUSSAS-COOP.AGROPECUARIA RUSSANA LTDA & -0.109 \\
\hline 93 & 38 & $\mathrm{CE}$ & COOPERATIVA AGRICOLA DE VICOSA LTDA & $-0,074$ \\
\hline 94 & 39 & CE & COOP AGROPECUARIA E INDL DE OROS LTDA & $-0,048$ \\
\hline 95 & 40 & CE & COOPERATIVA AGROP DOS PROD RURAIS DE QUIXADÁ LTDA & $-0,048$ \\
\hline 96 & 41 & $\mathrm{CE}$ & COOP AGROP E COM DO IMOVEL MACEIO LTDA & 0,067 \\
\hline 97 & 42 & $\mathrm{CE}$ & COOPERATIVA DOS PROD DE LEITE DE CEDRO LTDA & 0,069 \\
\hline 98 & 43 & $\mathrm{CE}$ & COOPERATIVA DE P AGROP DA LAGOA DO MINEIRO LTDA & 0,100 \\
\hline 99 & 44 & $\mathrm{CE}$ & COOP. AGROPECUARIA DOS PEQ. PROD. CRATEÚS & 0,148 \\
\hline 100 & 45 & CE & COOPAI-COOP.DOS PRODUT RURAIS DE IRACEMA LTDA. & 0,168 \\
\hline 101 & 46 & CE & COOPERATIVA AGROPECUARIA DE UBAJARA LTDA & 0,173 \\
\hline 102 & 47 & $\mathrm{CE}$ & COOPAAS-COOP.DOS PROD.RURAIS DE ALTO SANTO LTDA & 0,183 \\
\hline 103 & 48 & $\mathrm{CE}$ & COOPEMIL COOPERATIVA AGRICOLA MISTA DE MILAGRES LTDA & 0,199 \\
\hline 104 & 49 & $\mathrm{CE}$ & COOPERATIVA DOS IRRIGANTES DO VARZEA DO BOI LTDA. & 0,208 \\
\hline
\end{tabular}




\begin{tabular}{|c|c|c|c|c|}
\hline Num. Geral & Ord. Estado & Estado & RAZĀO SOCIAL & Escore \\
\hline 105 & 50 & $\mathrm{CE}$ & COOCAIA-COOPERATIVA DOS PRODUTORES RURAIS LTDA & 0,211 \\
\hline 106 & 51 & $\mathrm{CE}$ & CAPI - COOP. AGROPECUARIA DO PROJETO IRRIGADO LTDA. & 0,217 \\
\hline 107 & 52 & CE & COOCAMPOS-COOP.DOS PEQ.AGROP.DE CAMPOS LTDA & 0,235 \\
\hline 108 & 53 & CE & COOP.AGROP.DO PERIMETRO IRAIGADO DO VALE DO BANABUIÚ & 0,265 \\
\hline 109 & 54 & $\mathrm{CE}$ & COOP. MISTA DOS IRRIGANTES DE QUIXERAMOBIM LTDA. & 0,267 \\
\hline 110 & 55 & CE & COOPERATIVA AGRICOLA E INDUSTRIAL DE IGUATU LTDA. & 0,470 \\
\hline 111 & 56 & CE & COOPERATIVA AGROINDUSTRIAL DE MILAGRES LTDA & 0,495 \\
\hline 112 & 57 & CE & COOPERATIVA DOS PEQ. PROD. DE ICAPUÍ LTDA & 0,664 \\
\hline 113 & 58 & CE & COOPERATIVA AGRICOLA DOS PRODUTORES DO V. LTDA & 0,725 \\
\hline 114 & 59 & $\mathbf{C E}$ & COOP. DOS PEQ. PROD. AGROP. DE MORADA NOVA LTDA & 0,764 \\
\hline 115 & 60 & CE & COICO COOP AGRICOLA E INDUSTRIAL DE ICO LTDA. & 0,851 \\
\hline 116 & 61 & CE & COOP.CENTRAL AGROP.DOS IRAIG.DO VALE DO BANABUIÚ LTDA. & 0,901 \\
\hline 117 & 62 & CE & COOPERATIVA AGRICOLA DE QUIXADA & 0,970 \\
\hline 118 & 63 & $\mathrm{CE}$ & COOPERATIVA DOS PRODUTORES RURAIS DE ARA. LTDA. & 1,023 \\
\hline 119 & 64 & $\mathrm{CE}$ & COOP.DOS AGROP.DE SAO JOAO DO JAGUARIBE LTDA. & 1,219 \\
\hline 120 & 65 & $\mathrm{CE}$ & COOPERATIVA AGRIC E DE PROD DE MAFANGUAPE LTDA. & 1,221 \\
\hline 121 & 66 & CE & COOPERATIVA AGRIC E IND DE CEDRO LTDA & 1,430 \\
\hline 122 & 67 & $\mathrm{CE}$ & COAURORA COOP AGRICOLA MISTA DE AURORA LTDA & 1,437 \\
\hline 123 & 68 & CE & COOIPA-COOP.DOS IRRIG.DO PROJ.JAGUARIBE LTDA & 2,002 \\
\hline 124 & 69 & CE & COOPAL-COOP.DOS PROD E AGROPEC DE LIM. DO NORTE LTDA & 2,065 \\
\hline 125 & 70 & $\mathrm{CE}$ & COOP.DE ENERGIA TEL.E DESENV.DO BAIXO JAGUARIBE LTDA & 2,091 \\
\hline 126 & 71 & CE & COOPAR- COOP.AGROPECUARIA DE RUSSAS LTDA & 2,980 \\
\hline 127 & 1 & MA & COOPERATIVA MISTA DOS PRODS AGAIC TURIAC LTDA & $-0,635$ \\
\hline 128 & 2 & MA & COOP.M.A.L.GANDIDO MENDES LTDA & $-0,607$ \\
\hline 129 & 3 & MA & COOP DOS PEQ PAOD RUR STA RITA LTDA & $-0,604$ \\
\hline 130 & 4 & MA & COOPERVID COOP PEQ PROD VILA DIAMANTE LTDA. & $-0,601$ \\
\hline 131 & 5 & MA & COOP PEQ PROD AGROEXT AMARANTE MARANHAO LTDA & $-0,587$ \\
\hline 132 & 6 & MA & COOP MISTA PEQ PROD RUR COPAIBA LTDA & $-0,584$ \\
\hline 133 & 7 & MA & COOPERATIVA DOS PRODUTORES RURAIS DE BUR. LTDA & $-0,581$ \\
\hline 134 & 8 & MA & COOP DOS PEQ PROD AGROP JOAO LISBOA LTDA & $-0,569$ \\
\hline 135 & 9 & MA & COOPAEMA-COOP PEQ PROD AGROEX ESTR. LTDA & $-0,565$ \\
\hline 136 & 10 & $\mathrm{MA}$ & COOP DOS PEQ PROD AGROEXT DE IMPER. LTDA & $-0,544$ \\
\hline 137 & 11 & MA & COAVIMA-COOPERATIVA DOS AVICULTORES DO M. LTDA & $-0,093$ \\
\hline 138 & 12 & MA & COOPERATIVA AGRICOLA DE RIACHAO LTDA & $-0,035$ \\
\hline 139 & 13 & MA & COOPERATIVA MISTA AGROPECUARIA DE COLINAS LTDA. & 0.119 \\
\hline 140 & 14 & MA & COOP AGRIC MISTA B. DO CORDA LTDA & 0,467 \\
\hline 141 & 15 & MA & COOPERATIVA AGROP BATAVOLTDA & 0,704 \\
\hline 142 & 16 & MA & COOPERATIVA AGROPECUARIA BATAVO NORDESTE LTDA & 4,295 \\
\hline 143 & 1 & MG & COOPERATIVA DOS PRODUTORES RUAIS DE MATO LTDA & $-0,642$ \\
\hline 144 & 2 & MG & COOPERATIVA AGROPECUARIA DE MATO VERDE LTDA & -0.640 \\
\hline 145 & 3 & MG & COAPE COOPERATIVA AGRICOLA DOS PRODUTORE & $-0,638$ \\
\hline 146 & 4 & MG & COOPERATIVA DOS PROD. RURAIS DE CAPITAO LTDA & $-0,569$ \\
\hline 147 & 5 & MG & COOPERATIVA DOS FRUTICULTORES DE JANAUBA LTDA & $-0,552$ \\
\hline 148 & 6 & MG & COVAG-COOP.AGRIC.DE IRRIG.DO VALE GORUTU LTDA & $-0,407$ \\
\hline 149 & 7 & MG & COOP.AGROPECUARIA REGIONAL DE MONTES CLAROS LTDA & $-0,199$ \\
\hline 150 & 8 & MG & COOPERATIVA AGROPECUARIA DE CORINTO LTDA & $-0,137$ \\
\hline 151 & 9 & MG & COOP. DE CAEDITO RUAAL DO VALE DO GORUTUBA LTDA & 0,149 \\
\hline 152 & 10 & MG & COOPERATIVA MISTA DOS PROD.RURAIS DE JANUÁRIA LTDA & 0.175 \\
\hline 153 & 11 & MG & COOP.AGROP.MIST.CHAP.GAUCHA LTDA. & 0,238 \\
\hline 154 & 12 & MG & COOPERATIVA AGROPECUARIA DE LAGOA DOS P. LTDA. & 0,250 \\
\hline 155 & 13 & MG & COOPERATIVA DE PRODUTORES RURAIS DE BOCA LTDA. & 0,293 \\
\hline 156 & 14 & MG & COOPAGROL-COOP.PROD.RURAIS DE GRAO MOGOL LTDA & 0.452 \\
\hline 157 & 15 & $M G$ & COOPERATIVA DAS AREAS DE REFORMA AGRARIA LTDA. & 1,070 \\
\hline 158 & 16 & MG & COOP. PROD.RUR.FRANCISCO SA LTDA & 1.705 \\
\hline
\end{tabular}




\begin{tabular}{|c|c|c|c|c|}
\hline Num. Geral & Ord. Estado & Estado & RAZÃO SOCIAL & Escore \\
\hline 159 & 17 & MG & COOPERATIVA DE CREDITO RURAL DO NORTE DE MG. LTDA & 4,374 \\
\hline 160 & 1 & PB & COOPERATIVA AGRICOLA MISTA DE SANTA LUZIA LTDA. & $-0,628$ \\
\hline 161 & 2 & PB & COOP.AGRIC. MISTA DOS PROD.RURAIS DE NAZARÉ LTDA. & $-0,625$ \\
\hline 162 & 3 & PB & COOP. AGRIC.MISTA VALE DOS DINOSAUROS LTDA. & $-0,580$ \\
\hline 163 & 4 & PB & COLEITE-COOP M DOS PROD DE LEITE E GADO LTDA & $-0,510$ \\
\hline 164 & 5 & $\mathrm{~PB}$ & COOPERATIVA MISTA AGROPESQUEIRA DE COREM. LTDA & $-0,487$ \\
\hline 165 & 6 & PB & COOP M DOS IRRIG E EMPRES EM CIÉNCIAS AGRÁRIAS LTDA & $-0,419$ \\
\hline 166 & 7 & PB & COOP. AGROP. MISTA DE VARZEA LTDA & $-0,353$ \\
\hline 167 & 8 & PB & COOP AGRIC MISTA DOS IRAIG CAPOEIRA CAMI. LTDA & $-0,306$ \\
\hline 168 & 9 & PB & COAMTAL-COOP AGRIC MISTA DE TENENTE ANAN. LTDA & $-0,159$ \\
\hline 169 & 10 & PB & COOPERSANTA-COOP AGRIC MISTA VALE DO SAN. LTDA & $-0,136$ \\
\hline 170 & 11 & PB & COAPOLIS-COOP AGROP MISTA DE MARIZOPOLIS LTDA & $-0,123$ \\
\hline 171 & 12 & PB & COOP.AGRIC.MISTA DOS IRRIG.DE CONDADO LTDA & $-0,080$ \\
\hline 172 & 13 & PB & CAMSOL COOP AGRIC MISTA DE SOLANEA LTDA & $-0,048$ \\
\hline 173 & 14 & PB & COOP. DOS FRUTICULTORES DA SERRA DO TEIXEIRA LTDA & $-0,030$ \\
\hline 174 & 15 & PB & COOPERATIVA AGRICOLA MISTA DE POMBAL LTDA & 0,025 \\
\hline 175 & 16 & PB & COMMPROV-COOP M DOS MIN E PROD RURAIS LTDA & 0,120 \\
\hline 176 & 17 & PB & COOPERATIVA AGROPECUARIA DA REGIAO SERRA LTDA & 0,134 \\
\hline 177 & 18 & PB & COOPERATIVA AGRICOLA MISTA DE CACHOEIRA DOS ÍNDIOS & 0,312 \\
\hline 178 & 19 & PB & CERBAL COOP DE ENERG E DESENV RURAL DE B. LTDA & 0,349 \\
\hline 179 & 20 & PB & COOP AGRICOLA MISTA DE PATOS LTDA & 0,357 \\
\hline 180 & 21 & PB & COOP. AGRIC. MISTA DOS IRAIG. DE JURU LTDA & 0,443 \\
\hline 181 & 22 & PB & COOPALD-COOP.AGROP.DE LAGOA DE DENTRO LTDA & 0,501 \\
\hline 182 & 23 & $\mathrm{~PB}$ & COOP.AGROP.MISTA DE ARACAGI LTDA. & 0.686 \\
\hline 183 & 24 & PB & COOPERATIVA RUAAL MISTA DE SAO MAMEDE LTDA & 0,723 \\
\hline 184 & 25 & PB & COOP AGRICOLA MISTA DOS PROD RUR DO ASSE. LTDA & 0,755 \\
\hline 185 & 26 & PB & COOP AG MISTA DE GUARABIRA LTDA & 0,945 \\
\hline 186 & 27 & PB & COOP AGRIC MISTA DOS IRRIGANTES DE SĀO GONÇALO LTDA & 7,924 \\
\hline 187 & 1 & $\mathrm{PE}$ & COOPERATIVA DOS PRODUTORES DE SAO BENTO LTDA & $-0,642$ \\
\hline 188 & 2 & $\mathrm{PE}$ & COOPERATIVA AGRICOLA DO GRANDE RIO LTDA & $-0,642$ \\
\hline 189 & 3 & $\mathrm{PE}$ & COOPERATIVA AGRIC.MISTA PER.IRRIG.NILO COELHO LTDA & $-0,623$ \\
\hline 190 & 4 & PE & COOP.MISTA DOS PEQ.PRODUTORES DE BELO JARDIM LTDA & $-0,618$ \\
\hline 191 & 5 & PE & COOP.MISTA IND.E ARTESANAL DE STA. CRUZ LTDA & $-0,607$ \\
\hline 192 & 6 & PE & COOPERATIVA AGRIC MISTA DE BODOCO LTDA & $-0,605$ \\
\hline 193 & 7 & PE & COOPERATIVA AGRICOLA MISTA DE ALAGOINHA LTDA & $-0,604$ \\
\hline 194 & 8 & $\mathrm{PE}$ & COOPERATIVA MISTA DO P P DE DEF DE ARCOVERDE LTDA & $-0,602$ \\
\hline 195 & 9 & PE & COOP.AGRICOLA MISTA DE PARNAMIRIM LTDA & $-0,594$ \\
\hline 196 & 10 & PE & COOPERATIVA AGROPECUARIA DE FAZENDA NOVA LTDA & $-0,591$ \\
\hline 197 & 11 & PE & COOPERATIVA AGRICOLA DE SAO VICENTE LTDA & $-0,585$ \\
\hline 198 & 12 & PE & CAMPAVINO-COOP.AGRICOLA M.PEQ.AGRIC.VILA & $-0,582$ \\
\hline 199 & 13 & $\mathrm{PE}$ & COOPERATIVA DOS CAPAINOCULTORES DE SERTA & $-0,581$ \\
\hline 200 & 14 & PE & COOP. MISTA DOS ARTES DO AGA E SERTÂNIA LTDA & $-0,573$ \\
\hline 201 & 15 & PE & COAPEFAL-COOP.AGROPEUARIA DE FATIMA LTDA & $-0,572$ \\
\hline 202 & 16 & PE & COOPERATIVA AGROP.DOS P.RURAIS DO A.CAMU. LTDA & $-0,569$ \\
\hline 203 & 17 & PE & COOPERATIVA AGROPECUARIA DO SITIO SAO PAULO LTDA. & $-0,566$ \\
\hline 204 & 18 & $P E$ & COOPERATIVA MISTA DOS TRAB.RURAIS DE S. LTDA & $-0,563$ \\
\hline 205 & 19 & $\mathrm{PE}$ & COOP DE PRODUCAO AGROPECUARIA PANORAMA LTDA & $-0,562$ \\
\hline 206 & 20 & $P E$ & COOPERATIVA DE ENERGIA,COM.E DESENV.DO V LTDA & $-0,557$ \\
\hline 207 & 21 & $\mathrm{PE}$ & COOP.DOS AGRICULTORES DA FAZ.CATOLE LTDA & $-0,556$ \\
\hline 208 & 22 & $\mathrm{PE}$ & COOP CAPRINOCULTORES SITIO MANICOBA LTDA & $-0,551$ \\
\hline 209 & 23 & PE & COOPERATIVA AGROPECUARIA DE GLORIA DO GOITÁ LTDA & $-0,539$ \\
\hline 210 & 24 & PE & COOPERATIVA AGAOP DO DISTRITO DE APOTI LTDA. & $-0,537$ \\
\hline 211 & 25 & PE & COOPERATIVA DOS PAODUTORES RUAAIS DE CAC. LTDA & $-0,533$ \\
\hline 212 & 26 & PE & COOP.DOS PEQ.PRODUT.RUR.DE SAO BENTO LTDA & $-0,529$ \\
\hline
\end{tabular}




\begin{tabular}{|c|c|c|c|c|}
\hline Num. Geral & Ord. Estado & Estado & RAZÄO SOCIAL & Escore \\
\hline 213 & 27 & PE & COOP.DOS PEQ.AGROPECUARISTAS DE ARCOVERDE & $-0,527$ \\
\hline 214 & 28 & PE & COOPERATIVA DE PROD AGROPECUARIA SERAINHA LTDA & $-0,525$ \\
\hline 215 & 29 & PE & COOPERATIVA AGROPECUARIA DE MIRANDIBA LTDA & $-0,516$ \\
\hline 216 & 30 & $\overline{P E}$ & COOP DOS OVINOCULTORES CAPRINOCULTORES LTDA & $-0,509$ \\
\hline 217 & 31 & PE & COOP AGROPECUARIA DE CARNAIBA VELHA LTDA & $-0,509$ \\
\hline 218 & 32 & PE & COOP.MISTA AGROPEC.SAO JOSE BELMONTE LTDA & $-0,507$ \\
\hline 219 & 33 & $\mathrm{PE}$ & COOPERATIVA AGROPECUARIA RUAAL DA VARZEA LTDA & $-0,503$ \\
\hline 220 & 34 & $\mathrm{PE}$ & COOPERATIVA DOS AGRICULTORES DE BARAA LTDA & $-0,501$ \\
\hline 221 & 35 & $\mathrm{PE}$ & COOP.DOS PROD.RURAIS DE SANTANA DAS ALMA LTDA & $-0,499$ \\
\hline 222 & 36 & PE & COOPACAL LTDA & $-0,497$ \\
\hline 223 & 37 & PE & COOP MISTA DOS FLORICULTORES DE GARANHUNS LTDA & $-0, \overline{496}$ \\
\hline 224 & 38 & $\mathrm{PE}$ & COOPERATIVA MISTA PROD.ARTES. E IND. BEL LTDA & $-0,494$ \\
\hline 225 & 39 & $\mathrm{PE}$ & COOPERATIVA AGROPECUARIA JUREMA E CABACA & $-0,486$ \\
\hline 226 & 40 & PE & COOPERATIVA AGROPECUARIA DE ALGODOES LTDA & $-0,484$ \\
\hline 227 & 41 & $\mathrm{PE}$ & COOPERATIVA MISTA AGROPECUARIA DO MOCOS LTDA & $-0,481$ \\
\hline 228 & 42 & $\mathrm{PE}$ & COOPERATIVA AGROPECUARIA DE CAPOEIRAS LT & -0.481 \\
\hline 229 & 43 & $\mathrm{PE}$ & COOPERATIVA AGROPECUARIA DE JERICO LTDA & $-0,479$ \\
\hline 230 & 44 & $\mathrm{PE}$ & COOPERATIVA AGROPECUARIA DO SITIO CAJA LTDA & $-0,474$ \\
\hline 231 & 45 & PE & COORURAL-COOP.DOD.PROD.RUR. DA REGIAO D. LTDA & $-0,466$ \\
\hline 232 & 46 & PE & COOPERATIVA AGROPECUARIA DE AGUAS BELAS LTDA. & $-0,463$ \\
\hline 233 & 47 & $\mathrm{PE}$ & COOP.DOS PEQUENOS PRODUTORES RURAIS DE ALTDA & $-0,460$ \\
\hline 234 & 48 & PE & COOPERATIVA AGROPECUARIA DO CATIMBAU LTDA & $-0,458$ \\
\hline 235 & 49 & PE & COOPERATIVA AGROINDUSTRIAL DE BREJINHO LTDA & $-0,458$ \\
\hline 236 & 50 & PE & COOPERATIVA RURAL DO POVOADO DO CAMPO GR. LTDA & $-0,455$ \\
\hline 237 & 51 & $\mathrm{PE}$ & COOP PEQUENOS PRODUTORES RURAIS DE SITIO LTDA & $-0,451$ \\
\hline 238 & 52 & PE & COOPERATIVA RURAL DOS PEQ PROD DE AVES LTDA & $-0,451$ \\
\hline 239 & 53 & PE & COOPERATIVA AGROPECUARIA DE BETANIA LTDA & $-0,447$ \\
\hline 240 & 54 & PE & COOPERATIVA POPULAR VALE DO RIO UNA LTDA & $-0,445$ \\
\hline 241 & 55 & $\mathrm{PE}$ & COOPERATIVA AGRICOLA MISTA DE PASSIRA LTDA & $-0,444$ \\
\hline 242 & 56 & $\mathrm{PE}$ & COAMIC/COOPERATIVA AGRICOLA MISTA DOS IR. LTDA & $-0,434$ \\
\hline 243 & 57 & $\mathrm{PE}$ & COAVIC-COOP.AGROP.DA VILA CAJUEIRO LTDA. & $-0,404$ \\
\hline 244 & 58 & PE & CERTRI-COOP.DE ELETRIF.RURAL TRIUNFO LTDA & $-0,395$ \\
\hline 245 & 59 & PE & COAPETU-COOPERATIVA AGROPECUARIA DE TUPA LTDA & $-0,366$ \\
\hline 246 & 60 & $\mathrm{PE}$ & COOPERATIVA DOS PEQUENOS E MEDIO P.RURAI LTDA & $-0,356$ \\
\hline 247 & 61 & PE & COMAQ COOP MISTA AGROPECUARIA DA QUIXABA LTDA & $-0,354$ \\
\hline 248 & 62 & $\mathbf{P E}$ & COAPAMA-COOP.AGROP.DE PRODUTORES DA MAND. LTDA & $-0,317$ \\
\hline 249 & 63 & PE & CAMPEATA-COOP MISTA DOS PEQ AGRIC DE TAC. LTDA & $-0,289$ \\
\hline 250 & 64 & PE & CAMIPEC-COOP.AGRIC.M.DOS IRRIG.DO PERIM. LTDA & $-0,285$ \\
\hline 251 & 65 & PE & COMESA-COOPERATIVA DOS IRRIGANTES DE SAN. LTDA & $-0,241$ \\
\hline 252 & 66 & PE & COOP MISTA DOS TRAB RURAIS DE BELO JARDIM LTDA & $-0,220$ \\
\hline 253 & 67 & PE & COAMA-COOP. MISTA AGROPECUARIA E APICOLA LTDA & $-0,212$ \\
\hline 254 & 68 & $\mathrm{PE}$ & COOP. DE ENERGIA, COM. E DESENV. DO ALTO LTDA & $-0,138$ \\
\hline 255 & 69 & PE & CERSIL COOP ENERGIA COMUN DESENV RURAL V. LTDA & -0.061 \\
\hline 256 & 70 & $\mathrm{PE}$ & COOPERCAN/COOPERATIVA DOS PHODUTO RURAIS LTDA & $-0,041$ \\
\hline 257 & 71 & PE & COAPAM-COOPERATIVA AGROPECUARIA DE PADRE LTDA & -0.013 \\
\hline 258 & 72 & $\mathrm{PE}$ & COOP IRRIGANTES MEDIOS E PEQ PROD RURAL LTDA & 0,168 \\
\hline 259 & 73 & PE & COOP.AGROP.E DOS PROD. DE LEITE DE OURICURI LTDA & 0,174 \\
\hline 260 & 74 & $\mathrm{PE}$ & COOPERATIVA AGRICOLA MISTA P.I.DO BEBEDO LTDA & 0,481 \\
\hline 261 & 75 & $\mathrm{PE}$ & COMASIL-COOP.MISTA AGROP. E APICOLA DE S. LTDA & 0,552 \\
\hline 262 & 76 & $\mathbf{P E}$ & COOPERATIVA AGRICOLA MISTA DE SANHARO LTDA & 0,728 \\
\hline 263 & 77 & PE & COOP. DE AVICULTORES E SUINOCULTORES LTDA & 0,814 \\
\hline 264 & 78 & PE & CERALPA-COOP.ELETRIFIC.RURAL ALTO PAJEU LTDA & 0,834 \\
\hline 265 & 79 & PE & COOPERATIVA MISTA AGRICOLA DE SAO CAETANO LTDA & 0,874 \\
\hline 266 & 80 & PE & COOPERATIVA DE ELETR.RURAL NO AGRESTE PE. LTDA & 0,913 \\
\hline
\end{tabular}




\begin{tabular}{|c|c|c|c|c|}
\hline Num. Geral & Ord. Estado & Estado & RAZĀO SOCIAL & Escore \\
\hline 267 & 81 & $\mathrm{PE}$ & CAIVEP-COOP. MISTA DOS IFRIGS. DO VALE P. LTDA & 1,123 \\
\hline 268 & 82 & PE & COOPERATIVA AGROP SAO JOSÉ DO EGITO LTDA & 2,425 \\
\hline 269 & 1 & PI & COOPERATIVA AGROPECUARIA IRAIGANTES DO V. LTDA & $-0,630$ \\
\hline 270 & 2 & PI & COOPERATIVA MISTA AGROP DE BARRAS LTDA & $-0,623$ \\
\hline 271 & 3 & $\mathrm{PI}$ & COOP. DOS HORT. COM. DO ITARARE LTDA & $-0,608$ \\
\hline 272 & 4 & $\mathrm{Pl}$ & COOPERATIVA DE DESENV. RUR. DO VALE DO R. LTDA & $-0,607$ \\
\hline 273 & 5 & $\mathbf{P I}$ & COOP AGRIC MISTA LAG IRAIG PI LTDA & $-0,607$ \\
\hline 274 & 6 & $\mathbf{P I}$ & COOP AGROIND MISTA DOS PEQ PRODUTORES LTDA & $-0,607$ \\
\hline 275 & 7 & $\mathrm{PI}$ & COOP MISTA AGROP DE MONS GIL LTDA & $-0,553$ \\
\hline 276 & 8 & PI & COOMAP-COOP.MISTA AGROP.DE PEQ.PRODUTORES LTDA & $-0,553$ \\
\hline 277 & 9 & PI & COOPERATIVA AGROIND DE PEQ PROD. LTDA & $-0,547$ \\
\hline 278 & 10 & $\mathrm{PI}$ & COOPERATIVA AGROPECUARIA DE INHUMA LTDA & $-0,533$ \\
\hline 279 & 11 & $\mathrm{PI}$ & COOP.MISTA DE RIBEIRO GONCALVES LTDA & $-0,525$ \\
\hline 280 & 12 & $\mathrm{PI}$ & COOMAGRIL-COOP.MISTA AGROP.E AGROINDUSTRIAL LTDA. & $-0,506$ \\
\hline 281 & 13 & $\mathrm{PI}$ & COOP.MISTA DE ANTONIO ALMEIDA LTDA & $-0,495$ \\
\hline 282 & 14 & PI & COOP.AGROIND.PEQ.PRODUT.RUR URUCUI & $-0,487$ \\
\hline 283 & 15 & PI & COOP. MISTA AGROPECUARIA E APICOLA DE SIMŐES LTDA & $-0,468$ \\
\hline 284 & 16 & PI & COOPERATIVA MISTA DOS PEQ.PROD.RURAIS LTDA & $-0,458$ \\
\hline 285 & 17 & PI & COOPERATIVA MISTA DOS PEO.PROD.AGRO.VALE LTDA & $-0,456$ \\
\hline 286 & 18 & Pl & COOP AGROPEC DE LAGOA DO SITIO LTDA & $-0,455$ \\
\hline 287 & 19 & $\mathbf{P I}$ & COOP.AGROP.PROD.MICRO REGIAO DE OEIRAS LTDA & $-0,452$ \\
\hline 288 & 20 & $\mathbf{P I}$ & COOMPEP-COOP MISTA DOS PEQ PROD RURAIS LTDA & $-0,452$ \\
\hline 289 & 21 & PI & COOPERATIVA AGROPEC DOS IRRIGANTES DO CA. LTDA & $-0,447$ \\
\hline 290 & 22 & PI & COOPERATIVA DOS APICULTORES DE SOCORRO DO PIAUII LTDA & $-0,445$ \\
\hline 291 & 23 & $\mathbf{P I}$ & COAJA-COOP. AGROP. DE JAICOS LTDA & $-0,437$ \\
\hline 292 & 24 & $\mathbf{P I}$ & COOPERATIVA APICOLA DO VALE DO LONGA LTDA & $-0,425$ \\
\hline 293 & 25 & PI & COOP. MISTA AGROPECUARIA DOS PEQUENOS PROD. LTDA & $-0,394$ \\
\hline 294 & 26 & $\mathrm{PI}$ & COAPI-COOP.APICOLA DA GRANDE PICOS LTDA & $-0,366$ \\
\hline 295 & 27 & PI & COOPERATIVA APICOLA DA REGIAO VALENCIANA LTDA & $-0,336$ \\
\hline 296 & 28 & PI & COMPAI-COOP.MISTA DE P.A.DE ITAINOPOUS & $-0,237$ \\
\hline 297 & 29 & PI & COOP.MISTA AGROIND.DO VALE DO GURGUÉIA LTDA & $-0,228$ \\
\hline 298 & 30 & $\mathrm{PI}$ & COOP.DOS PEQ.PROD.DE HORTIFRUT DE TERESINA LTDA & $-0,186$ \\
\hline 299 & 31 & PI & COOPERATIVA MISTA AGRO-INDUSTRIAL DE INHUMA LTDA. & $-0,104$ \\
\hline 300 & 32 & $\mathrm{PI}$ & COOPERATIVA AGRIC MISTA DE ANGICAL DO PI LTDA & -0.088 \\
\hline 301 & 33 & $\mathrm{PI}$ & COFAUP-COOP.DE PROD.DE FAUT.DA M. REGIAO LTDA. & $-0,032$ \\
\hline 302 & 34 & $\mathbf{P I}$ & COOPERATIVA AGRICOLA DE SANTA ROSA LTDA & -0.022 \\
\hline 303 & 35 & Pl & COMASUL-COOP.MISTA AGROP.DE SUSSUAPARA LTDA & 0,074 \\
\hline 304 & 36 & $\mathbf{P I}$ & COOPERATIVA AGRICOLA MISTA DE AFAANIO LTDA & 0,337 \\
\hline 305 & 37 & $\mathbf{P I}$ & COOP AGROPEC IRRI PERIM I GURGUEIA LTDA & 0,547 \\
\hline 306 & 38 & PI & COOP. AGRIC. PEQ. PROD. DE OEIRAS-CAMPO & 0.873 \\
\hline 307 & 39 & $\mathrm{PI}$ & CAMPIL-COOP.APICOLA DA MICRO REGIAO DE PICOS LTDA. & 0.924 \\
\hline 308 & 1 & RN & COOP AGAIC MISTA DOS IARIG PERIM IRAIGAD. LTDA & $-0,638$ \\
\hline 309 & 2 & $\mathrm{RN}$ & COOPERATIVA AGRICOLA MISTA DE LAGOA SAL LTDA & $-0,627$ \\
\hline 310 & 3 & RN & COOPERATIVA DE CRED.R.DOS PLANTADORES LTDA & $-0,530$ \\
\hline 311 & 4 & RN & COOPERATIVA AGROPECUARIA DE MACAIBA LTDA & $-0,506$ \\
\hline 312 & 5 & RN & COOPERATIVA DOS PRODUTORES DE L. DE IRAC. LTDA & -0.415 \\
\hline 313 & 6 & RN & COOPERATIVA AGROPECUARIA DO SERIDO LTDA & $-0,406$ \\
\hline 314 & 7 & RN & COOPERATIVA AGROPECUARIA REGIONAL DE MAR. LTDA & $-0,406$ \\
\hline 315 & 8 & RN & COOPERATIVA DE DESENVOLVIMENTO RURAL LTDA & $-0,342$ \\
\hline 316 & 9 & RN & COOPERATIVA AGRICOLA MISTA DE S J SERIDO LTDA & $-0,242$ \\
\hline 317 & 10 & RN & COOPERATIVA AGRO-INDL DE COLON DA SERRA LTDA & $.0,153$ \\
\hline 318 & 11 & RN & COOPERATIVA AGROPECUARIA DE SANTO ANTON!. LTDA & -0.106 \\
\hline 319 & 12 & RN & COOPERATIVA CENTRAL DO RIO GRNDE DO NORT. LTDA & -0.104 \\
\hline 320 & 13 & RN & COOPERATIVA AGROPECUARIA DE SAO MIGUEL LTDA & 0,007 \\
\hline
\end{tabular}




\begin{tabular}{|c|c|c|l|c|}
\hline Num. Geral & Ord. Estado & Estado & RAZÄO SOCIAL & Escore \\
\hline 321 & 14 & RN & COOPERATIVA AGRICOLA MISTA DO CURIMATAU LTDA & 0,056 \\
\hline 322 & 15 & RN & COOPERATIVA AGRICOLA DOS P. DO MEDIO JAG. LTDA & 0,181 \\
\hline 323 & 16 & RN & CERVAP-COOPERATIVA DE ENERGIA RURAL DO V. LTDA & 0,220 \\
\hline 324 & 17 & RN & COOPERATIVA AGRICOLA MISTA DE MARTINS LTDA & 0,254 \\
\hline 325 & 18 & RN & CERSEL-COOP. DE ENERGIA E DESENV. RURAL LTDA & 0,257 \\
\hline 326 & 19 & RN & COOPERATIVA AGROPECUARIA DO ASSENTAMENTO LTDA & 0,494 \\
\hline 327 & 20 & RN & COOPERATIVA AGROPECUARIA DE SERRA NEGRA LTDA & 0,601 \\
\hline 328 & 21 & RN & COOPERATIVA AGROPECUARIA DE ITAU LTDA & 0,649 \\
\hline 329 & 22 & RN & COOPERATIVA REGIONAL MISTA DO ALTO OESTE LTDA & 0,769 \\
\hline 330 & 23 & RN & COOPERATIVA DE ENERGIA E DESENVOLV RURAL LTDA & 0,778 \\
\hline 331 & 24 & RN & COOPLAB-COOP.MISTA DO PROJ.DE C.DA L. LTDA & 0,831 \\
\hline 332 & 25 & RN & COOPERATIVA AGROPECUARIA DE CERRO CORA LTDA & 0,935 \\
\hline 333 & 26 & RN & COOPERATIVA AGRICOLA DE SAO JOAO SABUGI LTDA & 0,994 \\
\hline 334 & 27 & RN & COOPERATIVA AGROPECUARIA DE CAICO LTDA & 1,824 \\
\hline 335 & 28 & RN & COOPERATIVA AGROPECUARIA DE SAO TOME LTDA & 1,969 \\
\hline 336 & 29 & RN & COOPERATIVA REGIONAL MISTA DO APODI LTDA & 2,005 \\
\hline 337 & 1 & SE & COOPERATIVA AGROP. MISTA E DE C. AGRESTE LTDA & $-0,619$ \\
\hline 338 & 2 & SE & COOP.AGRICOLA DO PERIMETRO IRRIGADO DE P. LTDA & $-0,537$ \\
\hline 339 & 3 & SE & COOP. MISTA DOS AGRICULTORES DO TAEZE LTDA & $-0,358$ \\
\hline 340 & 4 & SE & COOP REG DOS ASSENTADOS DE REFORMA AGRARIA LTDA & $-0,231$ \\
\hline 341 & 5 & SE & COOPERATIVA CENTRAL DO ESTADO DE SERGIPE LTDA & 0,547 \\
\hline
\end{tabular}

Fonte: Banco do Nordeste. 


\section{APÊNDICE 2}

\section{COOPERATIVISMO AGROPECUÁRIO NORDESTINO}

Estrutura organizacional e posicionamento mercadológico

\section{INFORMAÇÕES CADASTRAIS}

Nome da Cooperativa:

Sigla:

Data de fundação:

Logradouro

Município:

CEP.: - DDD: Tel/Fax:

E-mail:

Nome dos entrevistados:

Cargo/Função:

\section{ATIVIDADES ECONÔMICAS DESENVOLVIDAS}

Indique a área geográfica (municípios) de atuação da cooperativa.

Indique as atividades econômicas exploradas pela cooperativa.

Indique as atividades que constituem o foco principal dos negócios da cooperativa.

Indique as atividades que fazem parte do negócio da cooperativa, mas são executadas por outras empresas (serviços terceirizados). 


\section{OBJETIVOS ORGANIZACIONAIS E ANÁLISE DE AMBIENTE}

Liste os três objetivos mais importantes da cooperativa:

Que fatores constituem oportunidades para a Cooperativa?

Relacione dois pontos fortes da cooperativa:

Que fatores constituem ameaças para a Cooperativa?

Relacione dois pontos fracos (dificuldades) da cooperativa

\section{RESUMO DAS DEMONSTRAÇÕES FINANCEIRAS}

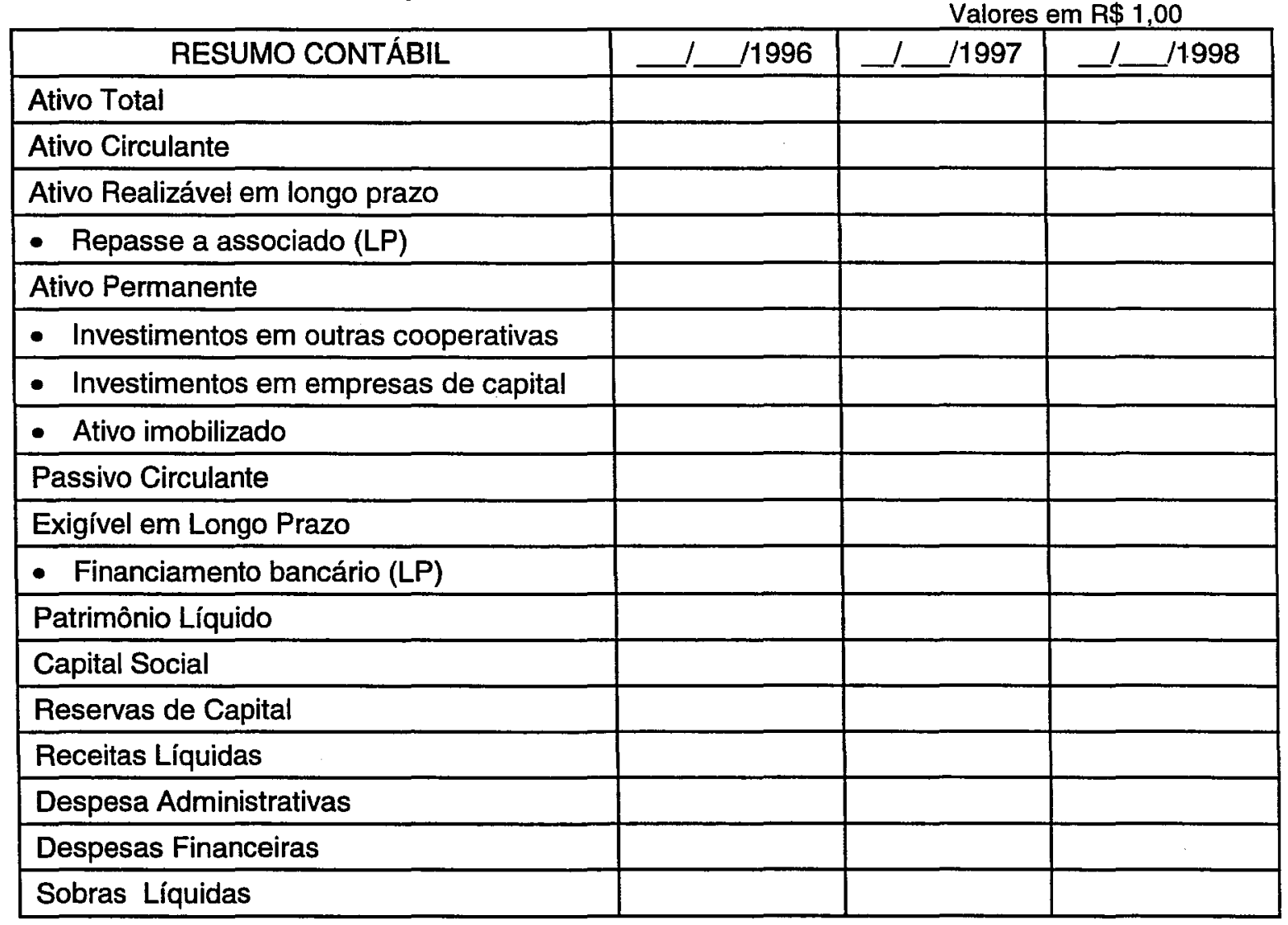



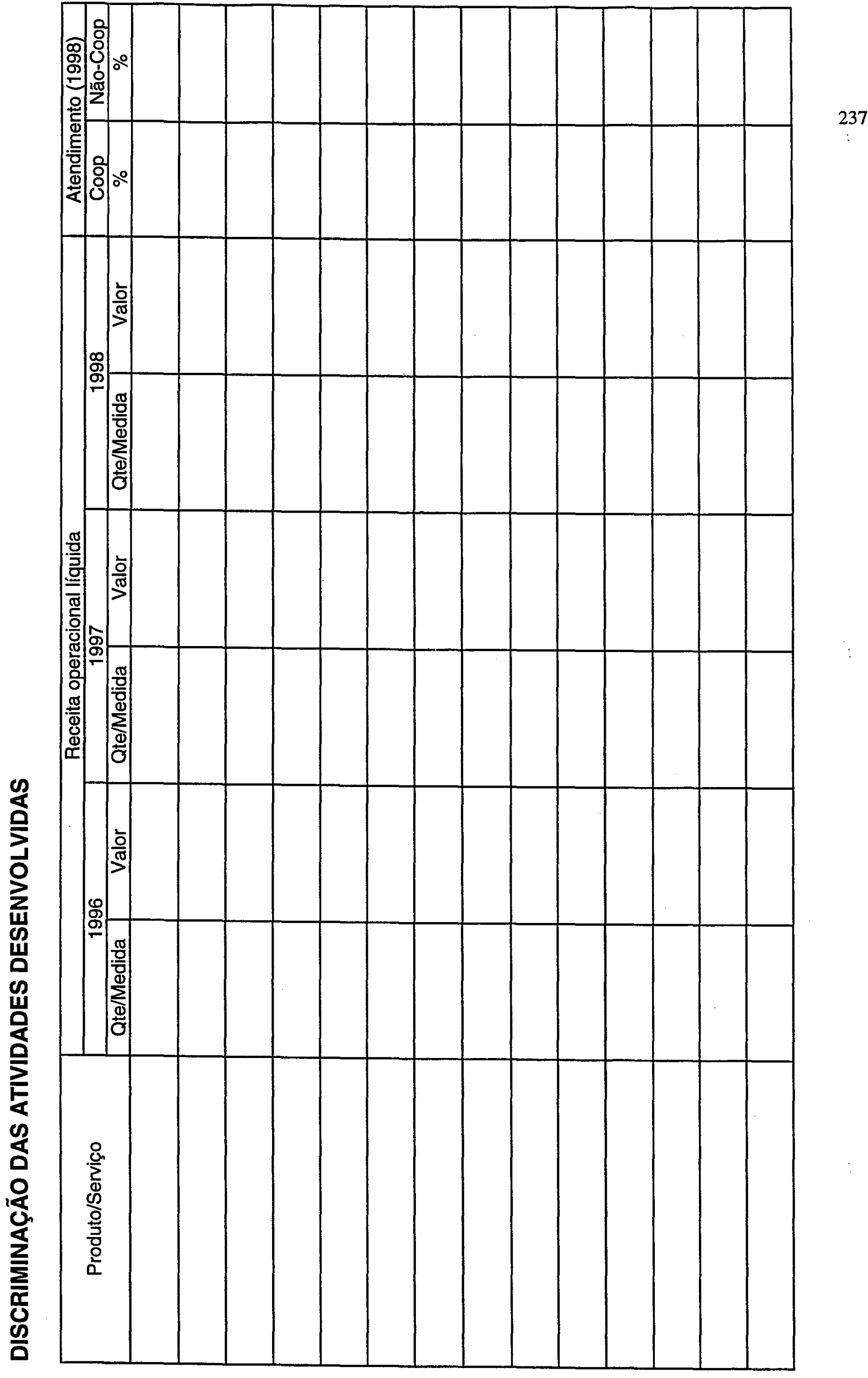


\section{QUADRO FUNCIONAL}

Para cada segmento funcional, indique o número de colaboradores, segundo o nível de escolaridade.

\begin{tabular}{|l|l|l|l|}
\hline \multicolumn{1}{|c|}{ Equipe de trabalho } & \multicolumn{3}{c|}{ Nivel de Formação } \\
\hline \multicolumn{1}{|c|}{ Cargo/Função } & Fundamental & Médio & Superior \\
\hline Diretoria & & & \\
\hline Gerência operacional & & & \\
\hline Gerência administrativa & & & \\
\hline Contador & & & \\
\hline Técnico agrícola & & & \\
\hline Agrônomo/Veterinário & & & \\
\hline Pessoal administrativo & & & \\
\hline Pessoal operacional & & & \\
\hline
\end{tabular}

A cooperativa possui profissionais externos contatados em nível de diretoria e gerência?

Em caso positivo, quais as áreas funcionais de atuação destes profissionais? Descreva-as :

\section{QUADRO SOCIAL}

Evolução recente do número de associados

\begin{tabular}{|l|l|l|l|}
\hline Associado & 31.12 .1996 & 31.12 .1997 & 31.12 .1998 \\
\hline Ativo & & & \\
\hline Inativo & & & \\
\hline Total & & & \\
\hline
\end{tabular}

Qual a presença média de associados nas assembléias em $1998 ?$
( ) até $20 \%$
( ) de 20 a $50 \%$
( ) de 50 a $70 \%$
( ) de 70 a $90 \%$
( ) acima de $90 \%$

Indique entre os fatores abaixo os três mais importantes, no processo de seleção/admissão de sócio.

( ) Livre entrada e saída de associados.

( ) Localização geográfica do produtor.

( ) Atividades produtivas exploradas pelo produtor.

( ) Compatibilidade entre as atividades do agricultor e o foco principal de negócios explorados pela cooperativa.

( ) Tamanho da exploração agropecuária.

( ) Capacidade do produtor rural na mobilização de capitais (próprios ou financiados), para futuros investimentos.

( ) Receptividade do produtor rural à inovação tecnológica. 
Que critérios são adotados para a classificação do cooperado como ativo, para fins de estratégias administrativas? Assinale apenas uma das alternativas.

( ) Realização de quaisquer transações econômicas, nos últimos doze meses com a cooperativa;

( ) Realização de transações econômicas correspondentes a pelo menos $30 \%$ do volume de negócios explorados pelo associado;

( ) Realização de transações econômicas correspondentes a pelo menos $60 \%$ do volume de negócios explorados pelo associado;

( ) Não existem critérios explícitos.

Como é feito o monitoramento, para fins de cumprimento das obrigações contratuais, entre cooperativa e produtor associado? Assinale a alternativa que melhor expresse a política da instituição:

( ) há contrato especifico (formal ou informal) prevendo o volume de transações.

( ) A cooperativa não determina o volume a ser entregue;

( ) Não há controles formalizados.

No caso de o cooperado realizar total ou parcialmente suas transações econômicas com terceiros, quais são as medidas adotadas pela cooperativa? Utilize a escala: 1=nunca; $2=$ eventualmente; $3=$ regulamente; 4=freqüentemente; $5=$ sempre:

( ) Advertência

( ) Multa

( ) Suspensão

( ) Exclusão/Eliminação

( ) Nenhuma medida é tomada

Qual o número de sócios excluídos e/ou eliminados por descumprimento de normas estatutárias relacionadas à fidelidade à cooperativa?

1996

1997

1998

A cooperativa fornece, diretamente ou por intermédio de terceiros, informações econômicas sobre o comportamento da atividade principal de seus cooperados (técnicas de produção, evolução de preço, oportunidade de negócios etc.)

( ) Nunca

( ) Ocasionalmente

( ) Regularmente

( ) Freqüentemente

( ) Sempre 
POLÍTICA INTERNA DE PREÇO: indique as alternativas que se aplicam à política interna de preço adotada pela cooperativa em favor do associado.

\begin{tabular}{|l|l|}
\hline \multicolumn{1}{|c|}{ Estratégia } & Realizada \\
\hline Preço diferenciado por qualidade do produto entregue. & $\operatorname{Sim}($ ) Não ( ) \\
\hline Preço diferenciado por quantidade de produto entregue. & $\operatorname{Sim}($ ) Não ( ) \\
\hline Preço diferenciado por regularidade na entrega de produto. & $\operatorname{Sim}($ ) Não ( ) \\
\hline Desconto diferenciado por volume de insumos adquiridos. & $\operatorname{Sim}($ ) Não ( ) \\
\hline Desconto diferenciado por regularidade na aquisição de insumos & $\operatorname{Sim}($ ) Não( ) \\
\hline Discriminação entre associado e não-associado & $\operatorname{Sim}($ ) Não( ) \\
\hline Recebimento da produção por preço acima da cotação de mercado. & $\operatorname{Sim}($ ) Não( ) \\
\hline Oferta de insumos por preço abaixo da cotação de mercado. & $\operatorname{Sim}($ ) Não( ) \\
\hline Distribuição de sobras; & $\operatorname{Sim}($ ) Não( ) \\
\hline Reinvestimento de sobras. & $\operatorname{Sim}($ ) Não( ) \\
\hline
\end{tabular}

SERVIÇOS OFERECIDOS: Indique os serviços efetivamente prestados pela cooperativa ao associado:

\begin{tabular}{|l|l|}
\hline Serviços & Realiza \\
\hline Capacitação técnico-produtiva do associado & $\operatorname{Sim}($ ) Não ( ) \\
\hline Beneficiamento/industrialização da produção & $\operatorname{Sim}($ ) Não ( ) \\
\hline Comercialização agropecuária & $\operatorname{Sim}($ ) Não ( ) \\
\hline Empréstimo ou financiamento & $\operatorname{Sim}($ ) Não ( ) \\
\hline Revenda de insumos agropecuários & $\operatorname{Sim}($ ) Não ( ) \\
\hline Armazenamento & $\operatorname{Sim}($ ) Não ( ) \\
\hline Transporte & $\operatorname{Sim}($ ) Não( ) \\
\hline Mecanização agrícola & $\operatorname{Sim}($ ) Não( ) \\
\hline Assistência técnica & $\operatorname{Sim}($ ) Não( ) \\
\hline Posto de combustivel & $\operatorname{Sim}($ ) Não( ) \\
\hline Supermercado & $\operatorname{Sim}($ ) Não ( ) \\
\hline
\end{tabular}




\section{RELACIONAMENTO INSTITUCIONAL}

Em que medida a cooperativa utiliza serviços das organizações abaixo relacionadas. Utilize a escala: 1=Nunca; 2=Ocasionalmente; 3=Regularmente; 4=Freqüentemente; 5=Sempre.

\section{GRAU DE UTILIZAÇÃo}

$\begin{array}{lllll}1 & 2 & 3 & 4 & 5\end{array}$

$\begin{array}{lllll}1 & 2 & 3 & 4 & 5\end{array}$

$\begin{array}{lllll}1 & 2 & 3 & 4 & 5\end{array}$

$\begin{array}{lllll}1 & 2 & 3 & 4 & 5\end{array}$

$\begin{array}{lllll}1 & 2 & 3 & 4 & 5\end{array}$

$\begin{array}{lllll}1 & 2 & 3 & 4 & 5\end{array}$

$\begin{array}{lllll}1 & 2 & 3 & 4 & 5\end{array}$

$\begin{array}{lllll}1 & 2 & 3 & 4 & 5\end{array}$

$\begin{array}{lllll}1 & 2 & 3 & 4 & 5\end{array}$

$\begin{array}{lllll}1 & 2 & 3 & 4 & 5\end{array}$

$\begin{array}{lllll}1 & 2 & 3 & 4 & 5\end{array}$

$\begin{array}{lllll}1 & 2 & 3 & 4 & 5\end{array}$

$\begin{array}{lllll}1 & 2 & 3 & 4 & 5\end{array}$

$\begin{array}{lllll}1 & 2 & 3 & 4 & 5\end{array}$

12345

\section{ENTIDADE}

Banco do Brasil
Banco do Nordeste
Bancos privados
Serviço público de assistência técnica
Empresas privadas de assistência técnica
Empresas de auditoria externa
Empresas de consultoria
Empresas de distribuição
Empresas de serviços de controladoria
Empresas de transporte
Sistema OCB/OCE
Cooperativa Central
Universidades
Bolsa de mercadorias
Instituição de pesquisa agropecuária

\section{ANÁLISE DE CONCORRÊNCIA}

Enumere os principais concorrentes da cooperativa, em ordem crescente de importância:

( ) Agroindústrias ou empresas de comercialização que atuam local ou regionalmente;

( ) Agroindústrias ou empresas de comercialização que atuam nacionalmente;

( ) Outras cooperativas;

( ) Empresas multinacionais instaladas no país;

( ) Empresas de outros países (produtos importados);

( ) Economia informal. 


\section{DISTRIBUIÇÃO}

Relativamente aos três principais produtos explorados, apresente a participação, em percentual, dos canais de distribuição utilizados.

Produto:

\begin{tabular}{|l|c|c|c|}
\hline \multicolumn{1}{|c|}{ Canal de distribuição } & 1996 & 1997 & 1998 \\
\hline Distribuição direta & & & \\
\hline Cooperativa Central & & & \\
\hline Agroindústria & & & \\
\hline Atacadista & & & \\
\hline Varejista & & & $100 \%$ \\
\hline Total & $100 \%$ & $100 \%$ & \\
\hline
\end{tabular}

Produto:

\begin{tabular}{|l|c|c|c|}
\hline \multicolumn{1}{|c|}{ Canal de distribuição } & 1996 & 1997 & 1998 \\
\hline Distribuição direta & & & \\
\hline Cooperativa Central & & & \\
\hline Agroindústria & & & \\
\hline Atacadista & & & \\
\hline Varejista & & & $100 \%$ \\
\hline Total & $100 \%$ & $100 \%$ & \\
\hline
\end{tabular}

Produto:

\begin{tabular}{|l|c|c|c|}
\hline \multicolumn{1}{|c|}{ Canal de distribuição } & 1996 & 1997 & 1998 \\
\hline Distribuição direta & & & \\
\hline Cooperativa Central & & & \\
\hline Agroindústria & & & \\
\hline Atacadista & & & \\
\hline Varejista & & & \\
\hline Total & $100 \%$ & & $100 \%$ \\
\hline
\end{tabular}


Indique o destino da produção dos três principais produtos explorados pela cooperativa

Produto:

\begin{tabular}{|l|c|c|c|}
\hline \multicolumn{1}{|c|}{ Destino da produção } & 1996 & 1997 & 1998 \\
\hline Mercado local (microrregião) & & & \\
\hline Mercado estadual & & & \\
\hline Mercado regional (Nordeste) & & & \\
\hline Mercado nacional (resto do país) & & & \\
\hline Mercado externo & & & $100 \%$ \\
\hline Total & $100 \%$ & $100 \%$ & \\
\hline
\end{tabular}

Produto:

\begin{tabular}{|l|c|c|c|}
\hline \multicolumn{1}{|c|}{ Destino da produção } & 1996 & 1997 & 1998 \\
\hline Mercado local (microrregião) & & & \\
\hline Mercado estadual & & & \\
\hline Mercado regional (Nordeste) & & & \\
\hline Mercado nacional (resto do país) & & & \\
\hline Mercado externo & & & $100 \%$ \\
\hline Total & $100 \%$ & $100 \%$ & \\
\hline
\end{tabular}

Produto:

\begin{tabular}{|l|c|c|c|}
\hline \multicolumn{1}{|c|}{ Destino da produção } & 1996 & 1997 & 1998 \\
\hline Mercado local (microrregião) & & & \\
\hline Mercado estadual & & & \\
\hline Mercado regional (Nordeste) & & & \\
\hline Mercado nacional (resto do país) & & & \\
\hline Mercado externo & & & \\
\hline Total & $100 \%$ & $100 \%$ & $100 \%$ \\
\hline
\end{tabular}




\section{AÇÕES ESTRATÉGICAS}

A cooperativa possui marcas próprias de produtos? Em caso positivo, indique o valor das vendas e os gastos feitos com propaganda, no exercício de 1998.

\begin{tabular}{|c|c|c|}
\hline Nome da marca & Vendas $(\mathrm{R} \$)$ & Propaganda $(\mathrm{R} \$)$ \\
\hline & & \\
\hline & & \\
\hline & & \\
\hline
\end{tabular}

Relacione as alianças de negócios ou de cooperação com outras organizações. Comente brevemente o(s) objetivo(s) pretendido(s) e o volume de recursos envolvidos.

\begin{tabular}{|l|l|l|}
\hline \multicolumn{1}{|c|}{ Organização } & Recursos (R\$) & Objetivo \\
\hline Outra cooperativa & & \\
\hline Agroindústria & & \\
\hline Atacadista & & \\
\hline Varejista & & \\
\hline Transportador & & \\
\hline Instituição de pesquisa & & \\
\hline Fornecedor & & \\
\hline
\end{tabular}

Indique as ações realizadas nos últimos três anos, para melhorar o desempenho dos negócios da Cooperativa.

\begin{tabular}{|c|c|c|}
\hline Tipo de Reforma & \multicolumn{2}{|c|}{ Realizada } \\
\hline Fusão/incorporação. & $\operatorname{Sim}($ & Não ( \\
\hline Terceirização de serviços. & $\operatorname{Sim}($ & Não ( \\
\hline Direcionamento dos recursos para atividades de maior valor adicionado. & $\operatorname{Sim}($ & Não ( \\
\hline Melhoria da fidelidade dos associados em relação à cooperativa. & $\operatorname{Sim}($ & Não ( \\
\hline Ampliação e melhoria dos serviços de assistência técnica. & $\operatorname{Sim}($ & Não ( \\
\hline Profissionalização da gestão. & $\operatorname{sim}($ & Não ( \\
\hline Controle de custos por tipo de serviço prestado. & $\operatorname{Sim}($ & Não( \\
\hline Redução de custo de produção. & $\operatorname{Sim}($ & Nãol \\
\hline Ênfase na utilização da capacidade produtiva. & $\operatorname{Sim}($ & Nãol \\
\hline Formação de alianças e parcerias. & $\operatorname{Sim}($ & Nãol \\
\hline Reconversão produtiva. & $\operatorname{Sim} 1$ & Não ( \\
\hline Aumento da linha de produtos. & $\operatorname{sim}($ & Nãol \\
\hline Redução da linha de produtos. & $\operatorname{Sim} 1$ & Nãol \\
\hline Diferenciação de produtos. & $\operatorname{sim}($ & Não ( \\
\hline Melhoria na qualidade dos produtos. & $\operatorname{Sim}($ & Não ( \\
\hline Desinvestimento de ativos ociosos. & $\operatorname{Sim}($ & Não ( \\
\hline
\end{tabular}


Indique as ações e/ou instrumentos de gestão administrativa utilizados correntemente pela cooperativa.

\begin{tabular}{|c|c|}
\hline GESTÃO ADMINISTRATIVA & Disponivel \\
\hline Contabilidade informatizada & $\operatorname{Sim}($ ) Não( ) \\
\hline Controle patrimonial e de mercadorias informatizados & Sim ( ) Não( ) \\
\hline Controle informatizados de contas a pagar e a receber & $\operatorname{Sim}($ ) Não( ) \\
\hline Sistemas de controle de qualidade & $\operatorname{Sim}($ ) Não( ) \\
\hline Treinamento de funcionários & $\operatorname{Sim}($ ) Não ( ) \\
\hline Sistema de gerenciamento de cadastro de clientes & $\operatorname{Sim}($ ) Não( ) \\
\hline Acompanhamento de custos por setores e/ou atividades & $\operatorname{Sim}($ ) Não( ) \\
\hline Unidade de cobrança ou utilização de serviços de terceiros & $\operatorname{Sim}($ ) Não( ) \\
\hline Sistema de acompanhamento de informaçōes de mercado & Sim ( ) Não( ) \\
\hline Investimento em propaganda e publicidade & $\operatorname{Sim}($ ) Não( ) \\
\hline Sistema de acompanhamento de associados & $\operatorname{Sim}($ ) Não( ) \\
\hline Auditoria interna ou externa & $\operatorname{Sim}($ ) Não ( ) \\
\hline Contratos e parcerias comerciais & $\operatorname{Sim}($ ) Não（） \\
\hline Sistema de comunicação interna & $\operatorname{Sim}($ ) Não( ) \\
\hline Plano de sucessão & $\operatorname{Sim}()$ Não( ) \\
\hline Realização de planejamento de médio e longo prazo & $\operatorname{Sim}($ ) Não ( ) \\
\hline
\end{tabular}

\section{ESTRUTURA OPERACIONAL}

Indique a(s) unidade(s) de beneficiamento e/ou industrialização existente(s):

\begin{tabular}{|l|l|l|}
\hline Agroindústria & $\begin{array}{c}\text { Capacidade } \\
\text { instalada }\end{array}$ & $\begin{array}{c}\text { Nivel médio de } \\
\text { utilização }\end{array}$ \\
\hline & & \\
\hline & & \\
\hline & & \\
\hline & & \\
\hline & & \\
\hline
\end{tabular}

